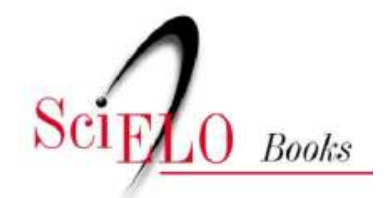

\title{
Um convite à utopia
}

\author{
Cidoval Morais de Sousa \\ (org.)
}

\section{SciELO Books / SciELO Livros / SciELO Libros}

SOUSA, C. M., org. Um convite à utopia [online]. Campina Grande: EDUEPB, 2016. Um convite à utopia collection, vol. 1, 398 pp. ISBN: 978-85-7879-488-0. Available from: doi:

$\underline{10.7476 / 9788578794880}$. Also available in ePUB from: http://books.scielo.org/id/kcdz2/epub/sousa9788578794880.epub.

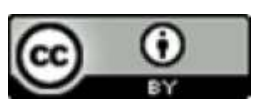

All the contents of this work, except where otherwise noted, is licensed under a Creative Commons Attribution $\underline{4.0 \text { International license. }}$

Todo o conteúdo deste trabalho, exceto quando houver ressalva, é publicado sob a licença Creative Commons Atribição 4.0.

Todo el contenido de esta obra, excepto donde se indique lo contrario, está bajo licencia de la licencia Creative Commons Reconocimento 4.0. 
焉
Universidade Estadual da Paraíba

Prof. Antonio Guedes Rangel Junior | Reitor

Prof. José Etham de Lucena Barbosa | Vice-Reitor

Editora da Universidade Estadual da Paraíba

Luciano do Nascimento Silva | Diretor

Antonio Roberto Faustino da Costa | Diretor-Adjunto

Conselho Editorial

Presidente

Luciano do Nascimento Silva

\section{Conselho Científico}

Alberto Soares Melo

Cidoval Morais de Sousa

Hermes Magalhães Tavares

José Esteban Castro

José Etham de Lucena Barbosa

José Tavares de Sousa

Marcionila Fernandes

Olival Freire Jr

Roberto Mauro Cortez Motta

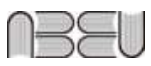

Editora filiada a ABEU

EDITORA DA UNIVERSIDADE ESTADUAL DA PARAÍBA

Rua Baraúnas, 351 - Bairro Universitário - Campina Grande-PB - CEP 58429-500 Fone/Fax: (83) 3315-3381 - http://eduepb.uepb.edu.br - email: eduepb@uepb.edu.br 
Cidoval Morais de Sousa

(Organizador)

\title{
Um convite à \\ UTOPIa
}

Volume 1

\begin{abstract}
Editores
Antonio Guedes Rangel Júnior

Antonio Roberto Faustino da Costa

José Luciano Albino Barbosa

Luciano do Nascimento Silva

Luis Henrique Herminio Cunha

Luiz Custódio da Silva

Thales Haddad Novaes de Andrade
\end{abstract}

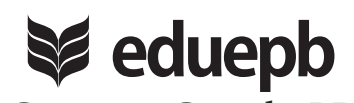

Campina Grande-PB

2016 
A reprodução não-autorizada desta publicação, por qualquer meio, seja total ou parcial, constitui violação da Lei no 9.610/98.

\section{Editora da Universidade Estadual da Paraíba}

Luciano do Nascimento Silva | Diretor

Antonio Roberto Faustino da Costa | Diretor-Adjunto

\section{Design Gráfico}

Erick Ferreira Cabral

Jefferson Ricardo Lima Araujo Nunes

Lediana Costa

Leonardo Ramos Araujo

Comercialização e Distribução

Danielle Correia Gomes

\section{Divulgação}

Zoraide Barbosa de Oliveira Pereira

\section{Revisão Linguística}

Elizete Amaral de Medeiros

\section{Normalização Técnica}

Jane Pompilo dos Santos

\section{Capa}

Projeto de Integração do Rio São Francisco, Eixo Norte, São Jose de Piranhas, Paraíba, Brasil. Fotografia feita durante visita de Campo organizada pela Universidade Estadual da Paraíba (UEPB), Campus Patos, em 13 de agosto de 2016. Fotografía: José Esteban Castro, disponível com Licença de Creative Commons (AttributionNonCommercial 2.0) no site de Flickr da Rede WATERLAT-GOBACIT: https://flic.kr/p/Lmtv3t.

Depósito legal na Biblioteca Nacional, conforme decreto nº 1.825, de 20 de dezembro de 1907.

C766 Um convite à utopia [Livro eletrônico]./ Cidoval Morais de Sousa (Organizador). - Campina Grande: EDUEPB, 2016. 2500 kb. 438 p. - (Coleção Um Convite à Utopia; v.1)

Modo de acesso: World Wide Web <http://www.uepb.edu.br/ ebooks/>

ISBN EBOOK 978-85-7879-321-0

ISBN IMPRESSO 978-85-7879-320-3

1. Critica ao capitalismo contemporâneo. 2. Esperança. 3. Utopia. 4. Bem viver. 5. Narrativa sobre o lugar perfeito. 6. Thomas Morus. I. Sousa, Cidoval Morais de. II. Título. 


\section{Agradecimentos}

Agradecimentos especiais a Jefferson Ricardo Lima Araujo Nunes, Erick Ferreira Cabral, Jane Pompilo dos Santos, Andreza Dantas Albuquerque e Larissa dos Santos Alves, pelo apoio e suporte técnico nas horas mais dificeis do projeto. $\mathrm{E}$ a todos os colaboradores deste volume (gratidão aos vivos, reverência aos mortos), pela aposta utópica: dias melhores virão! 


\section{O TEMPO QUE VIRÁ...}

Mesmo que não possamos adivinhar o tempo que virá, temos ao menos o direito de imaginar o que queremos que seja.

As Nações Unidas tem proclamado extensas listas de Direitos Humanos, mas a imensa maioria da humanidade não tem mais que os direitos de: ver, ouvir, calar.

Que tal começarmos a exercer o jamais proclamado direito de sonhar?

Que tal se delirarmos por um momentinho?

Ao fim do milênio vamos fixar os olhos mais para lá da infâmia para adivinhar outro mundo possível.

$\mathrm{O}$ ar vai estar limpo de todo veneno que não venha dos medos humanos e das paixões humanas.

As pessoas não serão dirigidas pelo automóvel, nem serão programadas pelo computador, nem serão compradas pelo supermercado, nem serão assistidas pela televisão.

A televisão deixará de ser o membro mais importante da família.

As pessoas trabalharão para viver em lugar de viver para trabalhar.

Se incorporará aos Códigos Penais o delito de estupidez que cometem os que vivem por ter ou ganhar ao invés de viver por viver somente, como canta o pássaro sem saber que canta e como brinca a criança sem saber que brinca. 
Em nenhum país serão presos os rapazes que se neguem a cumprir serviço militar, mas sim os que queiram cumprir.

Os economistas não chamarão de nível de vida o nível de consumo, nem chamarão qualidade de vida à quantidade de coisas.

Os cozinheiros não pensarão que as lagostas gostam de ser fervidas vivas.

Os historiadores não acreditarão que os países adoram ser invadidos.

O mundo já não estará em guerra contra os pobres, mas sim contra a pobreza.

E a indústria militar não terá outro remédio senão declarar-se quebrada.

A comida não será uma mercadoria nem a comunicação um negócio, porque a comida e a comunicação são direitos humanos.

Ninguém morrerá de fome, porque ninguém morrerá de indigestão.

As crianças de rua não serão tratadas como se fossem lixo, porque não haverá crianças de rua.

As crianças ricas não serão tratadas como se fossem dinheiro, porque não haverá crianças ricas.

A educação não será um privilégio de quem possa pagá -la e a polícia não será a maldição de quem não possa comprá-la.

A justiça e a liberdade, irmãs siamesas, condenadas a viver separadas, voltarão a juntar-se, voltarão a juntar-se bem de perto, costas com costas. 
$\mathrm{Na}$ Argentina, as loucas da Praça de Maio serão um exemplo de saúde mental, porque elas se negaram a esquecer nos tempos de amnésia obrigatória.
A perfeição seguirá sendo o privilégio tedioso dos deu- ses, mas neste mundo, neste mundo avacalhado e maldito, cada noite será vivida como se fosse a última e cada dia como se fosse o primeiro.

Eduardo Galeano 


\section{Nota TÉCNICA}

A coleção Um Convite à Utopia insere-se no contexto das comemorações dos 500 anos do lançamento do livro A Utopia (1516), de Thomas Morus. Trata-se de projeto editorial de natureza pública e coletiva, capitaneado pela Editora da Universidade Estadual da Paraíba (EDUEPB), com apoio da Associação Brasileira de Editoras Universitárias (ABEU) e uma série de instituições acadêmicas, científicas e culturais nacionais e estrangeiras. Pretende-se, de um lado, resgatar obras/textos que marcaram a construção da utopia como um projeto de contraposição a um mundo injusto e desigual; e, de outro, estimular a atualização da utopia, a partir de construções inéditas e provocadoras, articuladas em uma rede de esperanças. A ideia é que cada autor ou coletivo de autores, a partir de seu lugar de vida/mundo, produza um ensaio instigante, recuperando a necessidade de despertar do sono profundo em que se encontra o espírito utópico. Contemplam-se contribuições envolvendo a utopia que discutam obras/autores clássicos e contemporâneos; problematizem o cotidiano, a cultura e a totalidade; reflitam sobre o meio ambiente e os territórios de vida, cidadania, ética, justiça, tolerância; revisitem a história, economia, política, filosofia, teologia e magia; em suma, comunguem das lutas abertas à esperança. Trabalha-se, por opção, com o conceito agência solidária. Autores, editores, 
técnicos, distribuidores, apoiadores, divulgadores, enfim, todos se integram num propósito: colaborar, com ações criativas, para que a obra alcance o maior número de pessoas, ao menor custo possível. Cada volume será disponibilizado nas versões impressa e eletrônica e, com a contribuição dos associados e parceiros, temse por certo a constituição de uma grande rede de popularização e apropriação social deste Convite, no Brasil e no mundo. É um projeto aberto que enseja captar desejos, sonhos e movimentos em razão de um mundo novo; vontades e capacidades inequívocas de pensar e agir; uma práxis coletiva que contribua para eliminar, de vez, as sombras que têm ameaçado o amanhecer, particularmente, na América Latina. Que este Convite se projete como uma força mobilizadora das energias emancipatórias da humanidade.

Os Editores 


\section{SUMÁRIO}

Utopia, ainda que tardia

Cidoval Morais de Sousa

Notas sobre Utopia

Marilena Chauí

A mentalidade utópica

Karl Mannheim

Utopias por um mundo melhor

Adalmir Leonidio

Uma utopia da presença: situando mundos desejados nos lugares, espaços e sociedades em que vivemos

Nicole Aguilar Gayard

Mylène Tanferri

Benjamin Raimbault

Zara Mirmalek

O Buen Vivir: uma oportunidade de imaginar outro mundo

Alberto Acosta 
A utopia em questão: desalheamento educacional à objetividade.

Antonio Roberto Faustino da Costa

Pedro Bergamo

Roberto Marden Lucena

A verdadeira utopia

Slavoj Zizek

$\mathrm{O}$ reencantamento do mundo e acesso à informação: as potencialidades das Tecnologias de Informação e Comunicação (TICs) na construção e reforço da Democracia

Valdir Jose Morigi

Solange Inês Engelmann

Luis Fernando Herbert Massoni

Ketlen Stueber

Mídia, Cidadania e Utopia no Brasil

José Marques de Melo

Intelectuais e Web 2.0/3.0: como pensar, no $3^{\circ}$ milênio, a utopia do intelectual 365

Pedro de Andrade 


\section{UTOPIA, AINDA QUE TARDIA}

Cidoval Morais de Sousa ${ }^{1}$

A obra O fim da Utopia, de Russell Jacoby, (2001) é sintomática: a falta de uma visão de futuro tem paralisado a esquerda, de tal modo, que os intelectuais e críticos já não se mostram capazes de imaginar uma outra sociedade. Entramos "na era da aquiescência": estruturamos nossas vidas, nossas famílias e nossas carreiras com muito poucas expectativas. Sumiu do mapa, na sua asserção, "uma certa noção de utopia, a ideia de que o futuro pode transcender o presente". Falar de utopia hoje é correr riscos, uma vez que "poucos são os que encaram o futuro como algo mais que uma réplica do presente". Poucas coisas, segundo ele, parecerão mais "quixotescas ou irrelevantes", na contemporaneidade, do que defender o "impulso utópico."

Exagero ou não, o certo é que, como afirma Tamayo (2012), não vivemos tempos propícios à utopia. Vivemos um tempo de concessões, de silêncio, de preferência por ajustes, adequações, reformas. Um tempo com os pés num "cruzamento de sombras", que vêm do passado e do futuro (SANTOS, 1998). Não temos certeza se já fomos ou se ainda seremos. E o que seremos. Tempos

1 Professor da Universidade Estadual da Paraíba e Coordenador Geral da Coleção Um Convite à Utopia. Email: cidoval@gmail.com 
de apatia e indiferença. Tempos de silêncio. Em certa medida, aderimos (ou assumimos) à tese segundo a qual não há mais cura para as síndromes decorrentes da modernidade. Dentre elas, a mesmice crônica (mais do mesmo), a auto-suficiência (podemos e temos tudo e mais um pouco) e a auto-referência (é assim que se faz). Tais síndromes, em nosso ver, se espalham veloz e eficientemente por diferentes canais (mídia, por exemplo), contaminando o tecido social, ampliando as vozes dos que já se renderam ao "tudo está bem como está", e desqualificando os que insistem em contrariar o establishment reabilitando, criticamente, o ideal utópico.

As utopias, historicamente, emergem em tempos de crise, propondo, quase sempre, uma inversão da realidade: a paz em oposição à guerra; liberdade e democracia em tempos de ditadura; uma cidade feliz em tempos de caos urbano; a sustentabilidade do 'bem viver' em oposição ao desenvolvimento desigual e combinado, marca registrada do capitalismo contemporâneo; educação conectada com a vida, em tempos de 'escola sem partido'; ciência e tecnologia à serviço da vida, em contraposição à morte que sai dos laboratórios (de nossas universidades, inclusive), maioria das vezes comissionada com recursos públicos; uma mídia cidadã em tempos de mídia golpista (casos recentes no Brasil, Argentina e Venezuela).

Muitos já tentaram decretar a morte da utopia, ou a sua inutilidade. Ora, por ser confundida com alienação; ora, por não fazer sentido num mundo já locupleto e satisfeito com as 'maravilhas' da modernidade. Em 500 anos de experiência o conceito "caiu de conceito", foi renegado, teve seu tempo de deserto, foi ao inferno, mas, talvez contando com a proteção de seu criador, Thomas Morus, que virou santo depois de ser preso e executado por contrariar à Monarquia Inglesa, pode ser que se reabilite e volte a 
apontar caminhos. Esta coleção tem como proposta fundamental contribuir para essa reabilitação.

Seguindo Fátima Vieira (2012, p. 8), quem fala de utopia em tempos de crise "assume a função de timoneiro de um navio (como o que Saramago descreve em O Conto da Ilha Desconhecida) que transporta homens e mulheres com as mãos nos olhos, a servirem de pala, perscrutando o horizonte, na expectativa de serem os primeiros a gritar "Terra à vista" - e que acabam por perceber que a utopia está na procura, num processo de demanda que tem o efeito positivo de nos levar sempre mais além, de não nos deixar ficar parados"

\section{A Utopia, 500 anos}

Como já foi sinalizado na Nota Técnica dos Editores, esta Coleção se articula no contexto das comemorações dos 500 anos de publicação de $A$ Utopia, de Thomas Morus. Trata-se de um clássico da literatura mundial, publicado em 1516 e que continua a ser lido, discutido e analisado por sua agenda de críticas à acumulação perversa, à exploração do homem pelo homem e pela defesa incisiva de que o bem comum é mais valioso que o bem individual, e que a propriedade privada é o cerne das desigualdades sociais. A palavra "Utopia” geralmente é vinculada a algo irrealizável ou que não existe em lugar nenhum. Entretanto, pode, também, ser associada tanto a "nenhum lugar" (considerando a união do advérbio grego "ou" - que significa "nenhum" - ao substantivo "topos" - que significa "lugar" - "outopia"), quanto a um lugar feliz, um lugar onde se vive bem (considerando a união do advérbio "eu" - feliz - ao mesmo substantivo - "eutopia"). Utopia como "lugar nenhum" é, de fato, um lugar irreal; já como "lugar feliz", tem uma exigência ética e política que preside a elaboração deste sonho "utópico". 
No mundo de A Utopia, tudo é de todos. Sua mensagem, na compreensão de muitos leitores, acadêmicos e não acadêmicos, militantes de diferentes tendências à esquerda (nós editores incluídos), continua fazendo sentido, especialmente neste momento de aguda crise, com ameaças reais a conquistas históricas, como no caso brasileiro: há alternativas ao que está instituído. Lançado em Latim em 1516, é, como afirmam vários autores, um texto fundamental do humanismo. Numa época de monarquias, de colonização com extermínio da gente e dos recursos naturais do chamado Novo Mundo, a ilha de A Utopia apresenta um sistema político baseado na vontade do povo, numa forma de fazer política em que todos podem participar. Não é o mais perfeito dos lugares-sistemas (há flagrantes de totalitarismo), mas, considerando o contexto, representava, naquele momento, uma reforma singular nas estruturas políticas, econômicas e culturais da época.

Há quem afirme que da mesma maneira que Morus olhou para as desigualdades de seu tempo e apontou caminhos para um mundo novo, os reformistas sociais do século XIX fizeram o mesmo. A ideia de uma sociedade igualitária teria inspirado obras como as de Pierre Proudhom (1809-1865), Charles Fourier (17721837), Robert Owen (1771-1858) e Saint-Simon (1760-1825), classificados como "socialistas utópicos" por Marx (1818-1883), que ofereceu, em contraposição, o "socialismo científico". Não foi o primeiro texto da história sobre um ideal utópico (apesar de a palavra utopia ter sido criada por ele), entretanto inaugurou uma tradição de obras com agenda comum: projetos alternativos para uma sociedade em crise (Nova Atlântida, de Bacon; Cidade do Sol, de Campanella; Christianopolis, de Valentin Andrea; Oceana, de James Harrington, dentre outros). 


\section{Sobre o conteúdo deste volume}

Os ensaios para o primeiro volume de Convite foram selecionados levando-se em consideração os seguintes critérios: (1) textos importantes para compreender o contexto de produção e significado histórico da obra de Morus e sua atualidade; (2) produções que problematizassem o conceito de utopia numa perspectiva de reabilitação crítica; (3) textos que oferecessem, a partir de temas críticos da contemporaneidade, como cidades, comunicação, ciência, tecnologia e educação, leituras inovadoras, provocadoras, disseminadoras de utopias. Diante da quantidade e qualidade do material inédito recebido, graças a "viralização" da convocatória de textos nas redes sociais e das propostas de republicações postas à mesa, a Comissão decidiu por uma publicação mista, que contemplasse o clássico e o emergente. ${ }^{2}$ Com exceção do texto de Mannheim, $A$ Mentalidade Utópica, os ensaios republicados (4 no total) estão todos, em sua versão original, disponibilizados na Net, em acesso livre. Os demais textos são inéditos, foram escritos especialmente para a Coleção. A republicação, neste espaço, de textos considerados seminais para a reflexão sobre utopia, utópicos, utopias, na compreensão dos editores, reúne o que está disperso e torna possível novas leituras, diálogos, aproximações, críticas, atualizações, numa multiplataforma de esperanças.

O ensaio Notas sobre Utopia, de Marilena Chaui, uma das mais conhecidas e respeitadas filósofas brasileiras, seja por sua provocativa produção acadêmica, seja por sua militância política em defesa

2 A Convocatória continua aberta: ensaios de até 30 páginas sobre o tema Utopia, em suas diferentes dimensões, em documento do word, fonte arial, tamanho 12, intervalo entrelinhas 1,5. A normalização deve seguir padrão ABNT. Email para contato: cidoval@gmail.com; eduepb@uepb.edu.br 
da democracia e de um mundo mais justo, publicado em 2008 na Revista Ciência e Cultura, Editada pela SBPC, e já disponível na Net (ver endereço no próprio texto), abre a sequência de textos selecionados para o que estamos chamando de volume introdutório da Coleção Convite. Expõe de forma precisa os significados da palavra Utopia, título da obra seminal de Thomas Morus (1477[8?]-1535) e apresenta uma síntese das principais características da utopia em seu movimento histórico. Segundo Chaui, a utopia é (1) normativa (propõe um mundo tal como deve ser, em oposição ao mundo que se tem); (2) é sempre totalizante e crítica do existente; (3) é a visão do presente sob o modo da angústia, da crise, da injustiça, do mal, da corrupção e da rapina, do pauperismo e da fome, da força dos privilégios e das carências, ou seja, o presente é percebido como violência; (4) é radical (busca a liberdade e a felicidade individual e pública); (5) é uma maneira peculiar da imaginação social, que busca combinar o irrealismo, ou a crença na total transparência do social, e o realismo, por meio da apresentação dos mínimos detalhes da nova sociedade; (6) é um discurso cujas fronteiras são móveis, ou seja, a utopia pode ser literária, arquitetônica, religiosa, política. O utopista, na concepção de Chaui, é um revolucionário ou um reformador consciente do caráter prematuro e extemporâneo de suas ideias que, por isso, não podem ser postas como um programa. O texto inclui ainda uma leitura contextualizada da obra de Morus, sua repercussão e influência ao longo desses 500 anos e um balanço das críticas, incluindo as feitas por Marx e Engels.

Tomo aqui emprestado de Ozaí da Silva ${ }^{3}$ o seguinte trecho: "As ideologias mobilizam indivíduos e multidões, alimentam intolerâncias, intentam conservar ou transformar sociedades, produzem

3 Resenha publicada na revista Espaço Acadêmico, Edição Especial 08 anos, e disponível em: http://www.espacoacademico.com.br/096/96esp_ozai.htm 
guerras e revoluções. Qual seria a fonte dessa força imensa que se dissemina e conquista corações e mentes em povos de culturas e realidades tão díspares? Será porque expressam utopias? Ideologias e utopias são semelhantes, nomes diferentes para os mesmos fenômenos políticos e sociais? Se as ideologias sobrevivem ao passar dos anos e vivificam nos homens e mulheres do tempo presente, mesmo quando são declaradas mortas, será que vivemos uma época em que a utopia se exauriu?" Buscamos, a partir dessas provocações, inserir o leitor de Convite nesse debate aberto por Karl Mannheim (1893 -1947), em seu livro de 1929, Ideologia e Utopia, publicado no Brasil pela Zahar Editores em 1968. Selecionamos dessa obra clássica o capítulo IV, intitulado A Mentalidade Utópica, do qual destacamos que as utopias transcendem a situação social, pois orientam a conduta para elementos que a situação, tanto quanto se apresente em dada época, não contém. Mas elas, como bem acentua o autor, não são ideologias, isto é, não são ideologias na medida e até o ponto em que conseguem, através da contra-atividade, transformar a realidade histórica existente em outra realidade, mais de acordo com suas próprias concepções.

No ensaio Utopias por um mundo melhor, publicado na Revista de História Saeculum, em 2004, disponível na Net (endereço de acesso indicado no próprio ensaio), Adalmir Leonídio, pesquisador com destacada produção no campo dos estudos sociais da utopia, a proposição que ganha força no texto é que "a imagem da utopia como mero sonho, fantasia ou evasão da realidade, não parece mais ser aceita pelos estudiosos do tema", e que "tampouco ela parece revelar-se exclusivamente através do seu conteúdo revolucionário." Segundo ele, desde Platão, houve um número muito grande de utopias, correspondentes aos diferentes contextos em que tais obras emergiram. $\mathrm{O}$ autor, nesse ponto, provoca os leitores com uma pergunta: o que permite então falar em utopia 
como um dado conceito, uma realidade ou conteúdo que perpassa as diferentes manifestações literárias de natureza utópica? Sua resposta: a mundividência utópica revela uma série de elementos comuns: o modelo e a realização do modelo; a busca da unidade social e de uma sociedade harmônica e concorde, onde o todo é mais importante que as meras partes constituintes e conflitantes; enfim, a busca de uma ordem perfeita. Cada utópico, afirma Leonídio, em diferentes momentos, elaborou seus conteúdos de forma distinta: Platão, através de uma perfeita hierarquização das funções sociais; Morelly através de uma imitação da ordem natural por parte da ordem social; Babeuf através de uma radicalização do conteúdo igualitário dos princípios da Revolução Francesa, e assim por diante. E Leonídio finaliza com uma reflexão importante sobre a atualidade da utopia: o sentido mais importante e atual talvez seja o não conformismo, a não aceitação de nenhuma realidade como definitiva, a não ser aquela que eleve ao mais alto grau as potencialidades humanas, isto é, o otimismo de perspectiva e o ideal universalista do homem. Conforme a mensagem de Cândido, personagem de Voltaire, hoje repetida entre aqueles que ainda acreditam em alguma forma de utopia, "um mundo melhor é possível".

Num ensaio produzido exclusivamente para esta coletânea, Nicole Aguilar Gayard, Mylène Tanferri Benjamin Raimbault e Zara Mirmalek buscam renovar a atenção sobre as utopias, situando-as no tempo presente, nas práticas quotidianas, nos movimentos de reprodução ou de contestação social. Argumentam que as utopias podem ser percebidas nas práticas a partir das quais se pensam e se buscam soluções para os problemas sociais. Partem do conceito de heterotopia (elaborado por Foucault), que apresenta uma perspectiva situada do pensamento utópico, e incorporam a concepção dos imaginários sociotécnicos (desenvolvida por Sheila Jasanoff 
e Sang-Hyun Kim) a fim de entender os desejos de reforma como uma característica das sociedades presentes. Com base nestes conceitos, as autores constroem uma releitura sobre o reavivamento das utopias nas políticas contemporâneas. A perspectiva conceitual adotada, conforme as autoras, permite introduzir casos específicos, que retratam coletivos trabalhando em espaços e tempos situados, recuperando a importância dessas dimensões para suas vidas e articulando diferentes versões de ordenamentos sociais ou demostrando implicitamente a importância da interação entre significados e lugares. Os exemplos foram buscados em movimentos no Brasil (ocupação de escolas por estudantes em São Paulo), França (transformação do uso do espaço no aeroporto em Notre Dame des Landes), Suíça (novas formas de uso do espaço via habitações cooperativas) e nos Estados Unidos / China (reprodução de cidades ocidentais na China), pelos quais utopias foram criadas, transportadas e reformuladas.

O texto de Alberto Acosta, publicado, originalmente, na coletânea Um Campeão Visto de Perto - Uma Análise do Modelo de Desenvolvimento Brasileiro, Editada pela Heinrich Böll Foundation, na Série Democracia (2012), pontua que no contexto das discussões pós-desenvolvimentistas se multiplicam os esforços por uma reconstrução e inclusive pela superação da base conceitual, das práticas, das instituições e dos discursos do desenvolvimento. Nesta situação, segundo ele, há que se superar inclusive as visões heterodoxas, que enfocavam "desenvolvimentos alternativos", quando é cada vez mais necessário gerar “alternativas ao desenvolvimento". É nesse contexto que ele apresenta o Buen Vivir como uma oportunidade para construir coletivamente novas formas de vida. O Buen Vivir, diz ele, não é uma originalidade nem uma novidade dos processos políticos do início do século XXI nos países andinos. Nem é uma espécie de superstição ou poção 
mágica para todos os males do mundo. É parte de uma grande busca de alternativas "de vida forjadas no calor das lutas da humanidade pela emancipação e pela vida". A tarefa de reconstrução/ construção do Buen Vivir é, conforme acentua Acosta, descolonizadora (e despatriarcalizadora). Estabelece definitivamente uma cosmovisão diferente da ocidental ao surgir de raízes comunitárias não capitalistas e rompe, igualmente, com as lógicas antropocêntricas do capitalismo como civilização dominante e também dos diversos socialismos realmente existentes até agora.

Por sua vez, os professores Antonio Roberto Faustino da Costa, Pedro Bergamo e Roberto Marden Lucena respondem ao presente Convite, legando-nos um ensaio inédito e provocador ao processo civilizatório e cultural, a propósito, além das fronteiras capitalistas. A utopia em questão: desalheamento educacional à objetividade lança um conjunto de representações de cinco realidades à indeclinável condição para delimitar objetos do pensar e do agir, a partir de práxis educativo-coletiva "sui generis" enquanto proposta/realização educacional, objeto primacial de uma educação dos próprios educadores: interação entre sustentador(es) e prole naturalmente ainda autoinsustentável; excedência de produção de pertença cultural-socialmente indefesa junto aos destinatários; distinção entre produzir e apropriar os inelimináveis resultados; limites; e sentido inequívoco do que é coletivo. "Constituir algo que perfaça inequívoco sentido do que é coletivo adentra mudança no complexo âmbito do processo inseparavelmente civilizatório e cultural; civilizatório enquanto materializável e cultural enquanto pensável", acentuam os autores. Objetividade, neste horizonte, torna-se condição sine qua non a uma utopia que precisa ser realidade e da realidade que não poderia existir sem ser utópica.

Slavoj Zizek, respeitado polemista no universo intelectual da contemporaneidade, em dois curtos textos, o primeiro 
(A verdadeira utopia) divulgado no Brasil pela Revista Filosofia - Conhecimento Prático, e o segundo (Crença na utopia é ainda a melhor forma de questionar a exclusão social), divulgado no blog cesarkiraly.opsblog.org, a única questão verdadeira hoje é: o capitalismo global contém antagonismos fortes o suficiente para impedir sua reprodução indefinida? Zizek, em resposta, aponta quatro antagonismos: a ameaça iminente de uma catástrofe ecológica, o caráter inapropriado da propriedade privada para designar a chamada "propriedade intelectual", as implicações socioéticas dos novos desenvolvimentos tecnocientíficos (especialmente na biogenética) e, por último, mas não menos importante, as novas formas de apartheid, os novos muros e as favelas. Para Zizek, a nova política emancipatória não será mais o ato de um agente social particular, mas uma explosiva combinação de diferentes agentes. O que se deve rejeitar, no seu entendimento, é a ideologia liberal-vitimista que reduz a política à decisão de se evitar o pior, a renunciar de todos os projetos positivos e perseguir a opção menos ruim - ou, como notou amargamente Arthur Feldmann, o escritor judeu vienense, o preço que usualmente pagamos para sobreviver é a própria vida. A verdadeira utopia hoje "é a de que seremos capazes de resolver nossos problemas com transformações modestas no sistema existente".

Valdir Jose Morigi, Solange Inês Engelmann, Luis Fernando Herbert Massoni e Ketlen Stueber, pesquisadores da Universidade Federal do Rio Grande do Sul, no inédito O reencantamento do mundo e acesso à informação: as potencialidades das Tecnologias de Informação e Comunicação (tics) na construção e reforço da Democracia destacam que o uso e apropriações das TICs como ferramentas de mediação das informações e de visibilidade, de crítica da realidade e de reivindicações dos direitos parece ter se ampliado. Para eles, ao mesmo tempo em que o acesso à informação é facilitado, também 
é possibilitado o acesso à produção da informação, uma vez que a nova forma de interação social permite que diversos sejam os agentes produtores de informação. Por outro lado, a formação de uma esfera pública questionadora e crítica se encontra ausente, o que contribui com a tentativa de massificação e instrumentalização da opinião pública e busca de legitimidade por parte dos Estados e governos descomprometidos com a democracia. A construção de conteúdos solidários e que promovam a cidadania já são praticados no ciberespaço e em algumas mídias tradicionais, mas ainda de modo insuficiente. Torna-se, portanto, inquestionável que os meios de comunicação sejam capazes de produzir os conteúdos das informações de maneira autônoma, sem que sejam regidos pela lógica do mercado. Para os autores, refletir acerca do reencantamento do mundo a partir das TICs, acreditar em suas possibilidades, por mais utópicas que possam parecer, significa reivindicar seus aspectos práticos e efetivos. A regulação dos meios de comunicação e informação é uma forma importante de tornar as TICs e o ciberespaço em espaços de sociabilidade voltados a construção e reforço da democracia e à cidadania planetária.

O professor José Marques de Melo, um dos mais respeitados pesquisadores da área de comunicação na América Latina, também em texto inédito, Mídia, Cidadania e Utopia no Brasil Cidadania e Utopia, defende a tese segundo a qual Utopia e Cidadania são conceitos que brotaram de uma mesma conjuntura histórica. São filhos diletos da modernidade e simbolizam produtos das "liberdades urbanas", responsáveis pelo "primeiro surto desenvolvimentista" europeu. A Cidadania foi sendo conquistada em meio a "tensões sociais" e "lutas de classes", gerando situações de incertezas, quando as Cidades começaram a sofrer ameaças regulatórias por parte dos Estados "modernos". Os detentores do poder, nos emergentes Estados nacionais, trataram de refrear o ímpeto da Cidadania, da 
mesma forma que os guardiões da doutrina, no precursor Estado multinacional (Igreja Católica), não hesitaram em frear o poder revolucionário da Imprensa. O autor faz, também, um balanço das pesquisas sobre Mídia e Cidadania e afirma que elas tem reforçando a esperança de que a utopia da mídia cidadã deixe de ser "quimera" (ilusão, fantasia), concretizando-se através de processos capazes de evidenciar que "o homem e a mulher encerram a potencialidade de ser sujeitos da história". Entretanto, diz ele, o caminho a percorrer demanda esforço, perseverança e determinação. Trata-se de batalha cuja vitória depende fundamentalmente da vontade política dos sujeitos que estão na vanguarda da sociedade política. Mas a sociedade civil e a comunidade acadêmica podem exercer influência, acelerando o processo através de estudos e reflexões capazes de sensibilizar e convencer os que tomam decisões nas estruturas de poder.

O professor Pedro de Andrade, do Instituto de Ciências Sociais da Universidade do Minho, Portugal, em contribuição exclusiva para Convite, discute as relações entre intelectuais e Web 2.0/3.0, que, segundo ele, ainda são problemáticas. A via aberta pelo intelectual comum necessita ser explorada: (a) tanto pela cooperação mais intensa entre os cidadãos no seio dos instrumentos colaborativos da social web e da social semantic web; (b) quanto por meio da construção de novas metodologias de reflexão e pesquisa que dissolvam o atual hiato entre o saber especialista e o conhecimento ordinário. Para esse debate, Andrade propõe uma reflexão na forma de 6 questões para contextualizar as utopias globalizadas no terceiro milênio: (1) o que é a utopia e o que significa a eventual utopia da utopia; (2) espaços sociais da vida diária (espaço público/púbico das democracias ou espaço púdico dos fundamentalismos?); (3) tempo social do quotidiano: restos, rastos ou rostos?; (4) esferas sociais de interesses: criação/invenção/inovação? 
Desejamos meros contatos sociais, ou novos contratos sociais?; (5) História e sociologia da globalização: omni-modernidades ou/e pluri-modernidades?; (6) Hibridologia nas multiculturas, interculturas ou transculturas? Será que vivemos num mundo onde existem múltiplos encontros mas também encontrões e recontros, por ex. as hibridações ou embates e debates, entre povos, entre espaços e tempos, entre tipos e fluxos de capital, entre políticas (policies e politics), entre interculturas e transculturas?

\section{Bibliografia}

JACOBY, R. O fim da utopia: política e cultura na era da apatia. Tradução de Clóvis Marques. Rio de Janeiro: Record, 2001

TAMAYO, J.J. Invitación a la utopía. Estudio histórico para tiempos de crisis. Trotta, Madrid, 2012, 304 págs.

SANTOS, B.S. Um discurso sobre as ciências na transição para uma ciência pós-moderna. Estud. av., Ago 1988, vol.2, no.2, p.46-71.

VIEIRA, F. Falar de utopia em tempos de crise. Via Panorâmica. Número Especial.,2012. 


\section{NOTAS SOBRE UTOPIA ${ }^{1}$}

Marilena Chauí

A utopia nasce como um gênero literário - é a narrativa sobre uma sociedade perfeita e feliz - e um discurso político - é a exposição sobre a cidade justa.

Há pelo menos três aspectos curiosos no uso dessa palavra.

O primeiro é que foi inventada no século XVI por Thomas More - Utopia é o título de uma obra escrita por esse filósofo -, porém passou a ser empregada para designar narrativas e discursos muito anteriores, como, por exemplo, a cidade ideal na República de Platão, ou o projeto arquitetônico da cidade perfeita traçada pelo geômetra e astrônomo grego Hipodamos de Mileto, que, aplicando a geometria e a astronomia ao plano urbanístico, concebeu a

1 Versão originalmente publicada na Revista Ciência e Cultura, editada pela SBPC (Sociedade Brasileira para o Progresso da Ciência), em julho de 2008. Referência completa: CHAUI, Marilena. Notas sobre Utopia. Cienc. Cult.,São Paulo, v. 60, n. spe1,July 2008. Available from <http://cienciaecultura.bvs.br/scielo. php?script $=$ sci_arttext\&pid=S0009-67252008000500003\&lng $=$ en\&nrm $=$ iso $>$. access on 01Aug. 2016.

2 Marilena Chauí é professora-titular do Departamento de Filosofia da Faculdade de Filosofia, Letras e Ciências Humanas da Universidade de São Paulo (FFLCHUSP). 
cidade de acordo com a harmonia cósmica, ou ainda a descrição da Idade de Ouro nos poemas dos latinos Virgílio e Ovídio.

O segundo diz respeito ao sentido dessa palavra. Em grego, tópos significa lugar e o prefixo " $u$ " tende a ser empregado com significado negativo, de modo que utopia significa "não lugar" ou "lugar nenhum". Aliás, numa carta a Erasmo, Thomas More, inventor da palavra, enfatiza que a emprega no sentido negativo ou do "lugar nenhum". Aliás, é notória a presença de palavras negativas nessa obra de More, isto é, de palavras que se iniciam pelo prefixo grego "a", que também possui sentido negativo: a capital da ilha de Utopia é Amaurote, a não-visível, situada às margens do rio Anhydria, sem água, seus habitantes são os Alaopolitas, sem cidade, governados por Ademos, príncipe sem povo, e seus vizinhos são os Achorianos, homens sem terra.

O significado negativo da palavra utopia indica o traço definidor do discurso utópico, qual seja, o não-lugar é o que nada tem em comum com o lugar em que vivemos, a descoberta do absolutamente outro, o encontro com a alteridade absoluta. No entanto, um outro prefixo grego, "eu", é usado para dar um sentido afirmativo ou positivo a uma palavra, indicando nobreza, justeza, bondade, abundância. Assim, por exemplo, referindo-se à finalidade da política,Aristóteles usa eu zon para significar viver feliz ou bemviver. O sentido positivo pode ser observado em inúmeras palavras, como eubosía, a boa pastagem ou a pastagem abundante; eugéneia, nobreza de origem; eudaimonía, felicidade, prosperidade; eunóesis, benevolência; eupraxía, boa conduta, ação reta. Assim, o sentido positivo veio naturalmente acrescentar-se ao sentido negativo, de maneira que utopia significa, simultaneamente, lugar nenhum e lugar feliz, eutópos. Ou seja, o absolutamente outro é perfeito.

O terceiro aspecto curioso, que, aliás, nos concerne diretamente, refere-se à afirmação, hoje corriqueira, sobre o declínio ou 
o fim da utopia, decorrente do fracasso das revoluções socialistas, do refluxo do movimento operário mundial e do descrédito que pesa sobre o marxismo. Isso é curioso porque, como sabemos, Marx criticou as utopias e Engels escreveu uma pequena obra intitulada Socialismo utópico e socialismo científico, na qual comparava e opunha duas concepções do socialismo e, como Marx, recusava o socialismo utópico. Assim, é curioso que essa crítica seja esquecida e que o marxismo seja interpretado como utopia.

Todavia, talvez esses três aspectos sejam curiosos apenas em aparência e sob eles se encontrem razões que os expliquem. $\mathrm{Ou}$ melhor, é possível que a própria definição do que seja a utopia implique os três aspectos mencionados.

Bronislaw Baczko propõe a seguinte definição de utopia:

representação imaginada de uma sociedade que se opõe à existente a) pela organização outra da sociedade tomada como um todo; b) pela alteridade das instituições e das relações que compõem a sociedade como um todo; c) pelos modos outros segundo os quais o cotidiano é vivido. Essa representação, menos ou mais elaborada nos detalhes, pode ser encarada como uma das possibilidades da sociedade real e leva à valorização positiva ou negativa desta sociedade (Baczko, 1978, p. 405).

Em outras palavras, a utopia, ao afirmar a perfeição do que é outro, propõe uma ruptura com a totalidade da sociedade existente (outra organização, outras instituições, outras relações, outro cotidiano). Em certos casos, a sociedade imaginada pode ser vista como negação completa da realmente existente - como é o caso mais freqüente das utopias - , mas em outros, como visão de uma sociedade futura a partir da supressão dos elementos negativos da 
sociedade existente (opressão, exploração, dominação, desigualdade, injustiça) e do desenvolvimento de seus elementos positivos (conhecimentos científicos e técnicos, artes) numa direção inteiramente nova - como foi o caso, por exemplo, das utopias francesas do século XVIII, anteriores e posteriores à Revolução Francesa. Neste segundo caso, compreende-se que utopia possa significar eutópos e que o socialismo, por surgir de uma revolução integral, pudesse ter sido visto por muitos como utopia, apesar de Marx e Engels.

O fundamental, porém, é que em qualquer desses sentidos ruptura completa, desenvolvimento do que há de melhor numa sociedade existente — só pode haver utopia quando se considera possível uma sociedade totalmente nova e cuja diferença a faz ser absolutamente outra.

\section{II}

Antes de examinarmos a gênese das utopias, a partir da Renascença, e as críticas às concepções utópicas feitas a partir do século XIX, consideremos brevemente as principais características da utopia. Em sua busca da alteridade perfeita, a utopia:

1. É normativa, isto é, propõe um mundo tal como deve ser, em oposição ao mundo de fato existente.

2. É sempre totalizante e crítica do existente, ou seja, só há utopia quando há a representação de uma outra sociedade que negue ponto por ponto a sociedade existente, isto é, instituições, valores cívicos, éticos, estéticos e cognitivos, forma do poder, forma da propriedade, leis, permissões e proibições, forma da religião, forma da família e das relações pessoais entre adultos, entre estes e as crianças, os idosos etc. A utopia é criação de um mundo completo. 
3. É a visão do presente sob o modo da angústia, da crise, da injustiça, do mal, da corrupção e da rapina, do pauperismo e da fome, da força dos privilégios e das carências, ou seja, o presente é percebido como violência.

4. É radical, buscando a liberdade e a felicidade individual e pública, graças à reconciliação entre homem e natureza, indivíduo e sociedade, sociedade e Estado, cultura e humanidade, e à restauração de valores esquecidos ou descurados como a justiça, a fraternidade e a igualdade.

5. É uma maneira peculiar da imaginação social, que busca combinar o irrealismo, ou a crença na total transparência do social, e o realismo, por meio da apresentação dos mínimos detalhes da nova sociedade. A transparência é considerada o princípio fundamental da nova sociedade, que não oculta nem dissimula nenhum de seus mecanismos e nenhuma de suas operações. Os detalhes, por seu turno, servem para dar concreticidade à nova sociedade imaginada e cada detalhe exprime o todo e o simboliza. Dessa maneira, as instituições são signos do novo, do todo e da interiorização coletiva da boa sociedade.

6. É um discurso cujas fronteiras são móveis, ou seja, a utopia pode ser literária, arquitetônica, religiosa, política. Eis por que se pode falar em política utópica, arte utópica, ciência utópica, filosofia utópica, religião utópica. O fundamental, porém, é que esse discurso não é um programa de ação, mas um exercício de imaginação. Em outras palavras, o utopista é um revolucionário ou um reformador consciente do caráter prematuro e extemporâneo de suas idéias que, por isso, não podem ser postas como um programa. Como escreve Claude Gilbert Dubois, o discurso utópico permanece no plano potencial e hipotético, referido "a 
um possível que não traz consigo mesmo forçosamente a certeza de sua realização”. No entanto, o discurso utópico pode inspirar ações ou uma utopia praticada, que assume o risco da história, mas com a finalidade de alcançar o fim da história ou do tempo e atingir a perenidade.

\section{III}

Recordemos, brevemente, as condições históricas que fizeram esse gênero de discurso surgir durante a Renascença, portanto, entre os séculos XV e XVI.

Como já observamos, o termo utopia passou a ser empregado para referir-se a obras anteriores à Utopia de Thomas More. De fato, sob o impacto da obra de More, foram chamadas utópicas obras como a República de Platão, a Eneida de Virgílio, os poemas de Ovídio sobre a Idade de Ouro, o relato bíblico do Paraíso Terrestre e, particularmente, a esperança milenarista ou o simbolismo profético medieval do abade franciscano Joaquim di Fori, que interpretara a história segundo a imagem de três eras ou idades, a terceira e última das quais seria um tempo de sabedoria, sem escravos nem senhores, regida pelo amor e pela amizade, pelo espírito e pela liberdade. No entanto, ainda que todas essas obras pudessem de alguma maneira inspirar Thomas More, o sentido preciso do vocábulo utopia pertence à Renascença.

Destaquemos alguns aspectos do pensamento renascentista que estarão presentes na Utopia de More. Antes de mais nada o humanismo, ou seja, distanciando-se do teocentrismo medieval, a Renascença dá ao homem o lugar central. Desenvolve a idéia de que o homem é dotado de capacidade e força não só para conhecer a realidade, mas sobretudo para transformá-la, idéia que transparece num adágio que será celebrizado por Francis Bacon: "o homem é o arquiteto da Fortuna", ou seja, o homem é senhor de sua sorte 
ou de seu destino. O humanismo exalta a razão humana, a lógica e a experiência no plano do conhecimento, e a vontade no plano da ação, isto é, o poder para dominar, controlar e governar os apetites e as paixões.

O homem é, pois, capaz de guiar-se a si mesmo, desde que, por meio da razão e da vontade, estabeleça normas de conduta e códigos para todos os aspectos da vida prática. Essa idéia da racionalidade e do poder da vontade conduz a duas outras idéias, essenciais para o surgimento das utopias: a de que os homens valem por si mesmos, independentemente de privilégios de nascimento e sangue, de maneira que a oposição entre ricos e pobres é injusta e fonte das revoltas que destroem os Estados; e a de que é possível organizar um Estado sereno, feliz, glorioso e perfeito, fundado na eqüidade e dirigido por um verdadeiro príncipe.

Além disso, as viagens marítimas e a descoberta de novas terras e novos povos iriam inspirar a fantasia da sociedade perfeita de homens igualitários vivendo em plena harmonia com a natureza, tanto assim que a Utopia de More inaugura uma narrativa em que a descrição da cidade ideal é feita por um viajante, que navegou por mares nunca dantes navegados. A cidade ideal tende a ser colocada numa ilha cuja localização permanece desconhecida e à qual o viajante chega por acaso, em geral em decorrência de um naufrágio. Em outras palavras, as utopias tendem a ser viagens imaginárias a ilhas desconhecidas, nas quais os humanos exercitam plenamente suas capacidades benfazejas.

O humanismo político renascentista possui duas vertentes principais: a republicana e a monarquista. Os republicanos afirmam que o valor político fundamental não se encontra nas qualidades pessoais do governante e sim na liberdade. Se esta é o valor político supremo, que riscos podem ameaçá-la? Aqueles trazidos pela desigualdade. A liberdade só pode ser conservada por meio 
da igualdade, isto é, da justiça. Os monarquistas afirmam que o valor político fundamental é a paz. Que riscos podem ameaçá-la? A existência de facções, que acendem conflitos e rebeliões. A paz só pode ser conservada por meio da ordem, isto é, da lei. Essas duas vertentes do pensamento político serão reunidas na Utopia de More.

Vivendo numa Grã-Bretanha sacudida pelos tumultos da Reforma protestante e da Contra-Reforma católica, das lutas políticas e religiosas de facções que se digladiam no Parlamento e em campos de batalha, no período do surgimento da monarquia absoluta dos Tudors, ou de Henrique viii, que prefere a adulação, a corrupção e a mentira em vez da prudência e da verdade, Thomas More inventa uma sociedade ideal, na qual reinam a liberdade e a igualdade, a paz e a ordem, a justiça e a lei. Como é isso possível? Pela supressão da causa da desigualdade, isto é, a propriedade privada da terra com seus privilégios; e pela supressão da causa das facções e dos conflitos, isto é, o Estado como instância separada da sociedade e as igrejas, portadoras da intolerância religiosa.

Em Utopia, vigora a democracia direta, fundada na vontade coletiva guiada por homens virtuosos, e reina a tolerância religiosa. Opondo-se à pobreza e à injustiça, à corrupção e à desordem, à adulação e à mentira, o livro de More volta-se para a dignidade do trabalho e a crítica da ociosidade, propõe o planejamento da produção econômica e a distribuição igualitária dos bens, imagina a organização do tempo livre como momento não apenas de lazer e entretenimento, mas de dedicação à ciência e às artes, para que os homens possam viver segundo a razão e em harmonia com a natureza.

Não vamos aqui examinar o livro de More, mas assinalar um conjunto de aspectos que passaram a operar como modelo para obras e discursos utópicos. 
1. A utopia é busca da cidade feliz ou justa, cujo fundamento se encontra na excelência da legislação, ou na lei, e na pedagogia ou na educação dos cidadãos segundo a justeza e excelência da lei.

2. A utopia busca a estabilidade social e política, ou a estabilidade institucional, conseguida porque a fundação política é obra de um legislador excelente, que legisla para um povo novo, ainda não corrompido socialmente.

3. A utopia instaura a identificação de cada indivíduo com a lei ou com o Estado, ou seja, o consenso perfeito, a unanimidade das vontades dirigidas para um mesmo fim, de maneira que não há conflitos nem sedições.

4. A cidade ideal exerce uma vigilância permanente sobre todos os seus membros: o Conselho Dirigente costuma ocupar um palácio de vidro ou de cristal, de onde cada habitante possa ser visto, ficando sempre exposto ao olhar de todos.

5. A cidade ideal é coletivista: desaparece a família como núcleo social e os casamentos estão submetidos a regras sociais destinadas a manter o amor e a sexualidade sob controle; desaparecem a propriedade privada e o dinheiro, cada um recebendo segundo suas necessidades e capacidades, de maneira que estão eliminadas a desigualdade e a competição. A felicidade é sempre coletiva, cada um oferecendo-se como espelho para todos os outros.

6. A cidade ideal é insular, isto é, uma ilha isolada de todo o restante do mundo e cuja localização permanece secreta de modo a mantê-la protegida de ataques, invasões e más influências.Além de isolada e ilocalizada (donde u-topia), a cidade ideal é geométrica e arquitetonicamente planejada, ou seja, é produto de um urbanismo racional deliberado, 
que organiza o espaço segundo exigências sociais, políticas e econômicas. O urbanismo geométrico significa que a razão humana domina a desordem da matéria e os caprichos da natureza e da história. Escreve Raymond Trousson:

a cidade é o espelho e a medida do homem [...] o espaço fechado é a imagem da perfeição realizada [...] A figura geométrica fixa as formas e delimita sem equívocos um mundo à parte, pois a cidade utópica dobra-se sobre si mesma, sem contato com o exterior para evitar a corrupção [...]. Nada é caótico ou deixado ao acaso, mas tudo é regrado e previsto, pois o urbanismo e a arquitetura estão encarregados de refletir o estado moral da cidade (Trousson, 2004, p. 42).

7. O lugar do poder é claramente demarcado, tanto pela localização central quanto pelas características dos edifícios, que se distinguem das habitações. Estas tendem a ser homogênas e simples, enquanto a sede do poder civil tende a ser grandiosa e portentosa.

8. A cidade ideal é bela e esplendorosa, arborizada, florida, ampla, clara, limpa, com edificios públicos de mármore, rubi, safira, ouro e prata, enquanto as habitações particulares são simples, funcionais, limpas, arejadas e cercadas de jardins.

9. Embora a educação, a ciência e as artes sejam estimadas e estimuladas, a tendência é evitar — seguindo Platão - obras escritas. Em lugar de livros e bibliotecas, há reuniões, conversas, debates, trocas de opiniões e de idéias. 
Ou seja, evita-se o isolamento da escrita e da leitura e seu individualismo em proveito do grupo e da coletividade.

Há, ainda, um último traço da utopia que não provém da obra de More, mas da de um outro inglês, Francis Bacon, que, no início do século XVII, escreveu a Nova Atlântida. Como em More, a Nova Atlântida situa-se numa ilha cuja localização permanece secreta e foi alcançada pelo narrador em decorrência de um naufrágio. Por que nova Atlântida? Como se sabe, no diálogo Crítias, Platão narra o mito da Atlântida para opô-la às virtudes da Atenas antiga, cujas qualidades aristocráticas, guerreiras e frugais o filósofo julga destruídas pela democracia, com seu igualitarismo e opulência. Atlântida, na narrativa platônica, é a cidade injusta e passional, fundada por um deus (Poseidon) caprichoso e tumultoso, governada por reis, filhos bastardos do deus com as mortais, governantes arbitrários cuja vontade é lei.

Arquitetônica e politicamente, Atlântida é uma cidade oriental e mais precisamente persa, pois os gregos não podem esquecer as ameaças, guerras e invasões dos persas, que destruíram suas cidades e ameaçam outras. Atlântida é cidade ímpia e tirânica, que mereceu o castigo de Zeus, que a fez submergir no oceano. Em contrapartida, a nova Atlântida de Francis Bacon é uma sociedade harmônica, feliz e próspera, na qual a principal virtude é o conhecimento e sua aplicação para superar as limitações da condição humana. Dirigida por sábios, tem em seu centro a Casa de Salomão, um grande laboratório dedicado às investigações científicas e às pesquisas tecnológicas, pois somente o avanço dos conhecimentos assegura bem-estar e felicidade à população.

Seus cidadãos são cientistas; nela vigora a tolerância religiosa, embora a religião não tenha grande importância, pois, segundo o narrador, a sociedade cientificamente organizada já existia quando a ela, misteriosamente, chegaram os Evangelhos, 
ou seja, a verdade revelada e a fé vieram depois da ciência e são menos importantes do que esta, pois prudência, justiça, tolerância, benevolência, sobriedade e prosperidade são virtudes cívicas e não religiosas, nascidas do conhecimento e não da fé. A educação do jovem cientista visa prepará-lo não para igualar-se a seu mestre e sim para superá-lo, pois a Nova Atlântida é a utopia do progresso da ciência.

A tecnologia é, a um só tempo, fonte do progresso da ciência - graças à invenção de instrumentos cada vez mais precisos e efeito do progresso científico - o avanço dos conhecimentos inventa novas técnicas. Pesquisas em todos os campos do saber têm como finalidade prolongar a vida, manter a juventude e retardar o envelhecimento, curar doenças tidas como incuráveis, transformar o metabolismo, a estatura e a fisionomia, aumentar a capacidade cerebral, alargar os espíritos, criar novas espécies vivas e inorgânicas, produzir alimentos novos, produzir novos fios duradouros para o vestuário, aumentar os prazeres dos sentidos e, se possível, impedir a morte.

Se em Utopia é a política o elemento decisivo - isto é, a figura do legislador e do governante justo que guia a democracia direta, com a Nova Atlântida, o racionalismo e o experimentalismo científicos passam a integrar o discurso utópico, articulando intrinsecamente a cidade ideal e a ciência, isto é, o progresso do saber é o elemento decisivo e determina as obras utópicas posteriores. Assim, a partir do século XVIII e sobretudo do século XIX, na cidade utópica, as máquinas farão todo trabalho, deixando aos homens o tempo para cultivar o espírito e o corpo; a natureza estará completamente domada, submetida ao homem, que não mais se vê desarmado diante dela; as doenças estarão vencidas e a morte deixa de ser um enigma doloroso; sofrimentos e terrores, crueldades e acasos estarão completamente ausentes. 
É essa dimensão da utopia que dará origem a um novo gênero literário, a ficção científica, cuja primeira manifestação, no século XIX, encontra-se na obra de Júlio Verne.

\section{IV}

Esse conjunto de aspectos, brevemente apresentado, indica que, entre os séculos XVI e XVIII, a utopia é um jogo intelectual no qual o possível é imaginário, combinando a nostalgia de um mundo perfeito perdido e a imaginação de um mundo novo instituído pela razão.

Em contrapartida, quando passamos ao século XIX, a utopia deixa de ser um jogo intelectual para tornar-se um projeto político, no qual o possível está inscrito na história. Esta deixa de ser a narrativa de grandes feitos e de acontecimentos contingentes para ser concebida como ciência do encadeamento causal necessário dos fatos e das instituições humanas. Agora, a utopia é deduzida de teorias sociais e científicas, sua chegada é tida como inevitável porque a marcha da história e o conhecimento de suas leis universais garantem que ela se realizará. Deixa de ser obra literária para tornar-se prática organizada, passando a ser encarada pelos poderes vigentes como perigo real e a ser censurada como loucura.

Sob os efeitos da ciência e da técnica - isto é, da segunda revolução industrial - e da idéia de marcha necessária da história como progresso, o discurso utópico se torna realista e pragmático. Há uma positivização do imaginário utópico de maneira a diminuir a distância entre a cidade imaginária e a real, entre a história desejada e a vivida. Como escreve Baczko, há uma cientifização da utopia, que se torna um projeto de reforma global como ciência aplicada, e o futuro é arrastado para as fronteiras do presente, ou seja, a utopia surge como possibilidade objetiva, inscrita na marcha progressiva da história. 
É nesse novo contexto que se realiza a crítica de Engels e Marx ao socialismo utópico. A utopia, dizem eles, é um pressentimento ou uma prefiguração de um saber sobre a sociedade que o marxismo resgata no plano de uma ciência da história. Ou seja, assim como da alquimia se passou à química e da astrologia à astronomia, assim também é possível passar do socialismo utópico ao socialismo científico. O socialismo utópico é uma sabedoria afetiva e parcial, expressão do imaginário dos oprimidos. Em contrapartida, o socialismo científico é o amadurecimento racional do saber utópico dos dominados e o amadurecimento racional de sua prática política. Nesse sentido, o socialismo científico é a passagem do afetivo ao racional, do parcial ao totalizante, da antecipação ou pressentimento à emancipação revolucionária.

Em outras palavras, o socialismo utópico ergue-se contra o sofrimento dos humilhados e oprimidos, mas o socialismo científico é o conhecimento das causas materiais (econômicas e sociais) da humilhação e da opressão, ou seja, o modo de produção capitalista, fundado na luta de classes, que é determinada pela propriedade privada dos meios sociais de produção - a revolução socialista será, por isso mesmo, a passagem à propriedade social dos meios sociais de produção, passagem que será a ação política da classe economicamente explorada quando, por sua organização, conhecer-se a si mesma como classe.

Como se observa, o marxismo resgata o sentido do socialismo utópico assinalando sua parcialidade e sua pouca historicidade. Dessa maneira, a crítica marxiana se distingue da crítica conservadora (Comte, Durkheim, Sombart), para a qual a utopia é um miserabilismo nascido do medo da proletarização, uma quimera e uma loucura por excesso de imaginação.

Os conservadores absorvem a história na natureza e afirmam que a utopia é antinatural, isto é, absurda: desejar o fim da propriedade 
privada seria o mesmo que desejar a fonte da eterna juventude, uma impossibilidade natural. Marx e Engels distinguem dois tipos de propriedade: a propriedade privada dos bens necessários à vida e à vida feliz, e a propriedade social dos meios sociais de produção.

Isto lhes permite distinguir dois tipos de utopia: aquela que permanece como sombra da sociedade existente, oferecendo-se como doutrina, sistema, filosofia e pedagogia para as massas - esse tipo de utopia é inaceitável - e aquela que antecipa e prefigura a sociedade futura como sociedade nova que nega a sociedade presente - é essa utopia que o socialismo científico assimila e transforma. Em outras palavras, o socialismo marxiano valoriza na utopia seu caráter antecipador de um saber concreto sobre o social e seu caráter prefigurador da sociedade nova.

Também sob esse aspecto, a posição de Marx e Engels se distancia do cientificismo conservador. De fato, este parte de uma indagação: são as utopias realizáveis? Essa pergunta pressupõe, em primeiro lugar, a identificação do possível com o provável — isto é, nega a dimensão criadora do possível, achatando-o numa probabilidade que seria cientificamente demonstrável; conseqüentemente, em segundo, que a história abriga um único possível; e, em terceiro, que o utopista o conhece e possui a visão completa do futuro. Dessa maneira, o valor de uma utopia é medido por um critério não-utópico, qual seja, a previsibilidade científica e a unicidade do possível. Ora, nenhuma utopia influenciou o curso da história por seu realismo, mas, ao contrário, pela negação radical das fronteiras do real instituído e por oferecer aos agentes sociais a visão de inúmeros possíveis. O utopista desloca a fronteira daquilo que os contemporâneos julgam possível.

A crítica marxista à interpretação conservadora aparece claramente em Marcuse, quando denuncia a redução da utopia à mera ideologia, que supõe que toda forma do mundo, toda transformação 
do meio técnico e do meio natural é uma probabilidade real que tem seu lugar, seu tópos na história. Ou seja, ao passar do u-tópos ao tópos, do não-lugar a um lugar pre-fixado na história, a ideologia cientificista proclama o fim das utopias. Nesse mesmo sentido, também se colocando numa perspectiva marxista, Manheim, em Ideologia e utopia, distingue os dois termos. Utopia é a negação do tópos da classe dominante ou uma visão global da sociedade que se opõe à da classe dominante; é uma elaboração da classe historicamente ascendente e expressão de seus anseios profundos. Em contrapartida, ideologia é o sistema global de representações e valores da classe dominante, que deformam e mistificam a realidade social, imobilizando a consciência de classe. Dessa maneira, a utopia não é propriamente um discurso, mas um conjunto de práticas e de movimentos sociais contestadores da sociedade presente no seu todo.

\section{V}

Seria preciso, como conclusão, articular os principais aspectos do discurso utópico (aqueles nove, que mencionei acima) e o fenômeno do totalitarismo.

Essa articulação foi feita na segunda metade do século XX em vários romances, como, por exemplo, 1984, de Orwell, Admirável mundo novo, de Huxley, e Farenheit 541, de Bradbury. E reaparece, no início do século XXI, no primeiro filme da trilogia Matrix.

Referindo-se à articulação entre os elementos próprios do discurso e da narrativa utópicos e o totalitarismo, alguns autores falam em distopia, o tópos dilacerado e infeliz. As obras de distopia nos levam do sonho ao pesadelo.

Mas isto é uma outra história que fica para uma outra vez. 


\section{Referências Bibliográficas}

BACZKO, Branislaw. 1978. Lumières de l'utopie. Paris: Payot.

TROUSSON, Raymond. 2004. "La cité, l'architecture et les arts en

Utopie”. Morus. Utopia e Renascimento, n. 1. 


\section{A MeNTAlidade UTÓPICA ${ }^{1}$ \\ Karl Mannheim}

\section{Utopia, ideologia e o problema da realidade}

UM ESTADO DE ESPÍRITO é utópico quando está em incongruência com o estado de realidade dentro do qual ocorre.

Esta incongruência é sempre evidente pelo fato de que este estado de espírito na experiência, no pensamento e na prática se oriente para objetos que não existem na situação real. Contudo, não devemos encarar como utópico todo estado de espírito que esteja em incongruência com a situação imediata e a transcenda (e, neste sentido, "afastado da realidade"). Iremos referir como utópicas somente aquelas orientações que, transcendendo a realidade, tendem, se se transformarem em conduta, a abalar, seja parcial ou totalmente, a ordem de coisas que prevaleça no momento.

Ao limitar o significado do termo "utopia" ao tipo de orientação que transcende a realidade e que, ao mesmo tempo, rompe as amarras da ordem existente, estabelece-se uma distinção entre os estados de espírito utópicos e os ideológicos. Uma pessoa pode-se orientar para objetos que sejam estranhos à realidade e

1 IV capítulo do livro Ideologia e Utopia, publicado no Brasil pela ZAHAR EDITORES, em 1968, traduzido da edição publicada em 1960 por Routleddge \& Kegan Paul Ltda, de Londres Inglaterra. 
que transcendam a existência real e, não obstante, permanecer ainda ao nível da realização e na manutenção da ordem de coisas existente. No decurso da história, o homem tem-se ocupado mais frequentemente com objetos que transcendem seu âmbito de existência do que com os imanentes a ela e, apesar disso, formas efetivas e concretas de vida social têm sido construídas com base em tais estados de espírito "ideológicos" que estão em incongruência com a realidade. Esta orientação incongruente somente se tornou utópica quando, em acréscimo, tendeu a por fim aos laços da ordem existente. Em consequência, os representantes de uma dada ordem não adotaram em todos os casos uma atitude hostil para com as orientações que transcendessem a ordem existente. Antes, sempre pretenderam controlar estas ideias e interesses situacionalmente transcendentes, impossíveis de serem efetivados no quadro da ordem vigente, tornando-os, dessa forma, socialmente impotentes, de modo que tais ideias fossem confinadas em um mundo além da história e da sociedade, onde não pudessem afetar o status quo.

Todos os períodos da história contiveram ideias que transcendiam a ordem existente, sem que, entretanto, exercessem a função de utopias; antes, eram as ideologias adequadas a este estágio de existência, na medida em que estavam "organicamente" e harmoniosamente integradas na visão de mundo característica do período (ou seja, não ofereciam possibilidades revolucionárias). Enquanto a ordem medieval, organizada feudal e clericalmente, pode situar seu paraíso fora da sociedade, em qualquer outra esfera do mundo que transcendesse a história e que amortecesse seu potencial revolucionário, a ideia de paraíso ainda constituía parte integrante da sociedade medieval. Somente depois que certos grupos incorporaram estas imagens desiderativas à sua conduta efetiva foi que estas ideologias se tornaram utópicas. Se utilizarmos a terminologia 
de Landauer ${ }^{2}$, e, em consciente oposição à definição usual, chamarmos toda ordem social em curso e efetivamente existente de "topia" (da Palavra grega topos), então estas imagens desiderativas que assumem uma função revolucionária se tornarão utopias.

Claro está que uma concepção definitiva de "existência" e uma concepção correspondente da transcendência da existência é subjacente a distinção acima. Esta suposição deve ser profusamente investigada antes de avançarmos. A natureza da "realidade" ou a "existência em si" constitui um problema que pertence à filosofia e que não tem interesse aqui. Entretanto, o que em um dado momento deva ser encarado sociológica ou historicamente como "real" é de importância para nós e, felizmente, pode ser definidamente determinado. Na medida em que o homem é uma criatura primariamente vivendo "na história e na sociedade", a "existência" que o cerca jamais constitui uma "existência em si", mas é sempre uma forma histórica e concreta de existência social. Para o sociólogo, a "existência" consiste no que é "concretamente efetivo", isto é, uma ordem social em funcionamento, que não exista apenas na imaginação de certos indivíduos, mas de acordo com a qual as pessoas realmente ajam.

Toda "ordem operante de vida" concreta deve ser concebida e caracterizada mais claramente por meio da particular estrutura política e econômica em que se baseie. Mas abarca igualmente todas as formas de "vida em conjunto" humana (formas específicas de amor, sociabilidade, conflito, etc.) que a estrutura torna possível ou requer; e também todos os modos e formas de experiência e pensamento característicos deste sistema social e, consequentemente, em congruência com ele. (Para e presente enunciado do

2 Laudauer, G., Die Revolution, vol. 13 da série Die Gesselschaft, ed. Por Martin Buber (Frankfurt). 
problema isso é suficientemente preciso. Não se pode negar que, a se levar adiante o ponto de vista a partir do qual se faz a análise, ainda haveria muito mais a explicar. A extensão em que um conceito explica algo jamais pode ser absoluta; sempre é correlata à expansão e à intensificação do entendimento da estrutura total.) Mas toda ordem de vida "efetivamente operante" contém concepções a que se pode designar de "transcendentes" ou "irreais" porque seus conteúdos jamais podem ser realizados nas sociedades em que existem e porque não se poderia viver e agir segundo eles dentro dos limites da ordem social existente.

Em uma palavra, todas as ideias que não caibam na ordem em curso são "situacionalmente transcendentes" ou irreais. As ideias que correspondem à ordem de fato, concretamente existente, são designadas como "adequadas" e situacionalmente congruentes. Estas são relativamente raras, e somente um estado de espírito que tenha sido totalmente esclarecido sociologicamente opera com ideias e motivos situacionalmente congruentes. Em contraste com as ideias adequadas e congruentes, existem duas categorias principais de ideias que transcendem a situação as ideologias e as utopias.

As ideologias são as ideias situacionalmente transcendentes que jamais conseguem de fato a realização de seus conteúdos pretendidos. Embora se tornem com frequência motivos bem intencionados para a conduta subjetiva do indivíduo, seus significados, quando incorporados efetivamente a prática, são, na maior parte dos casos, deformados. A ideia do amor fraterno cristão, por exemplo, permanece, em uma sociedade fundada na servidão, uma ideia irrealizável e, neste sentido, uma ideia ideológica, mesmo quando o significado pretendido constitui, em boa-fé, um motivo da conduta do indivíduo. É impossível viver harmoniosamente, à luz do amor fraterno cristão, em uma sociedade que não se acha organizada sob o mesmo princípio. O indivíduo se vê, em 
sua conduta pessoal, sempre forçado --- na medida em que não recorre à ruptura da estrutura social existente --- a renunciar a seus motivos mais nobres.

$O$ fato de que esta conduta ideologicamente determinada sempre fique aquém de sua significação pretendida pode apresentar-se sob várias formas - e correspondendo a estas formas existe toda uma série de tipos possíveis de mentalidade ideológica. Podemos ter, como o primeiro tipo desta série, o caso em que o indivíduo que pensa e concebe-se ache impedido de tomar consciência da incongruência de suas ideias com a realidade em virtude do corpo total de axiomas implicado em seu pensamento histórica e socialmente determinado. Um segundo tipo de mentalidade ideológica é a "mentalidade hipócrita", que se caracteriza pelo fato de que, historicamente, tenha a possibilidade de desvendar a incongruência entre suas ideias e suas condutas, mas, ao invés de o fazer, oculta estas percepções, em atenção a determinados interesses vitais e emocionais. Como um tipo final, existe a mentalidade ideológica que se baseia no logro consciente, em que se deve interpretar a ideologia como sendo uma mentira deliberada. Neste caso não estamos tratando com a auto-ilusão, mas antes com o enganar deliberadamente outra pessoa. Existe um número infindável de estágios transicionais variando desde a mentalidade bem intencionada situacionalmente transcendente, passando pela "mentalidade hipócrita", até a ideologia no sentido de mentiras conscientes"’ A esta altura, não há necessidade de nos ocuparmos ainda mais com estes fenômenos. É entretanto necessário chamar a atenção para cada um destes tipos, a fim de perceber com maior clareza a peculiaridade do elemento utópico quanto a este aspecto.

3 Para maiores detalhes, cf. Parte II, "Ideolofia e Utopia". 
As utopias também transcendem a situação social, pois também orientam a conduta para elementos que a situação, tanto quanto se apresente em dada época, não contém. Mas não são ideologias, isto é, não são ideologias na medida e até o ponto em que conseguem, através da contra-atividade, transformar a realidade histórica existente em outra realidade, mais de acordo com suas próprias concepções. Ao observador que delas tenha uma visão relativamente externa, esta distinção teórica e completamente formal entre utopias e ideologias parece oferecer pouca dificuldade. Contudo, determinar concretamente o que em um dado caso seja ideológico e o que seja utópico é extremamente difícil. Aqui nos defrontamos com a aplicação de um conceito que envolve valores e padrões. Para que tal aplicação se efetue, deve-se necessariamente partilhar dos sentimentos e das motivações das partes em luta pelo assenhoreamento da realidade histórica.

$\mathrm{O}$ que em um dado caso aparece como utópico, e o que aparece como ideológico, depende essencialmente do estágio e do grau de realidade a que se esteja aplicando este padrão. Claro está que os estratos sociais representantes da ordem intelectual e social prevalecente irão experimentar como realidade a estrutura de relações de que são portadores, ao passo que os grupos de oposição a ordem presente irão orientar-se em favor dos primeiros movimentos pela ordem social por que lutam e que, por seu intermédio, se está realizando. Os representantes de uma ordem dada irão rotular de utópicas todas as concepções de existência que do seu ponto de vista jamais poderão, por princípio, se realizar. De acordo com esta utilização, a conotação contemporânea do termo "utópico" é predominantemente a de uma ideia em princípio irrealizável. (Pusemos deliberadamente de lado esta significação do termo na definição mais estreita.) Dentre as ideias que transcendem a situação, existem certamente algumas que em princípio jamais 
poderiam realizar-se. Não obstante os homens, cujos pensamentos e sentimentos se acham vinculados a uma ordem de existência na qual detêm uma posição definida, manifestarão sempre a tendência a designar de absolutamente utópicas todas as ideias que se tenham mostrado irrealizáveis apenas no quadro da ordem em que eles próprios vivem. Sempre, porém, que, nas páginas seguintes, falarmos de utopia estaremos usando o termo no sentido relativo, uma utopia significando, assim, o que pareça irrealizável tão-só do ponto de vista de uma dada ordem social vigente.

A própria tentativa de determinar o significado do conceito "utopia" mostra a que ponto toda definição, no pensamento histórico, depende necessariamente da perspectiva da pessoa, isto é, contém em si mesma todo o sistema de pensamento que representa a posição do pensador em questão e especialmente as valorações políticas subjacentes a este sistema de pensamento. A própria forma pela qual se define um conceito e o matiz com o qual empregado já encerra, em certo grau, um juízo prévio quanto ao produto da corrente de ideias elaborada sobre ele. Não é por acaso que um observador que, consciente ou inconscientemente, tenha assumido uma posição a favor da ordem social prevalecente, deve possuir uma concepção ampla e indiferenciada do utópico; isto e', uma concepção que suprime a distinção entre a inviabilidade absoluta e a relativa. Desta posição, é praticamente impossível transcender os limites do status quo. Esta relutância em transcender o status quo tende para a posição de encarar algo invejável apenas dentro da ordem dada, como se fosse totalmente invejável em qualquer ordem, de tal forma que, ao se obscurecerem estas distinções, se possa suprimir a validade das pretensões da utopia relativa. Chamando de utópico tudo o que ultrapasse a presente ordem existente, afasta-se a ansiedade que poderia ser provocada pelas utopias relativas, viáveis em outra ordem. 
No extremo oposto se encontra o anarquista G. Landauer (Die Revolution, págs. 7 e segs.) que considera a ordem existente um todo indiferenciado e que, somente atribuindo valor à revolução e a utopia, vê em toda topia (a presente ordem existente) o próprio mal. Assim como os representantes de uma ordem existente não diferenciam as variedades de utopia umas das outras (permitindo-nos falar de uma cegueira quanto à utopia), também se pode acusar o anarquista de cegueira quanto à ordem existente. Percebemos em Landauer o que é característico em todos os anarquistas, a saber, a antítese entre o "autoritário" e o "libertário" uma oposição que simplifica tudo e que encobre todas as diferenças parciais, englobando como autoritário tudo, desde o Estado policial, passando pela república democrática, até o Estado socialista, enquanto somente o anarquismo é considerado libertário. A mesma tendência para a simplificação se opera igualmente na forma pela qual se retrata a história. Esta dicotomização rude obscurece as indubitáveis diferenças qualitativas entre cada uma das formas de Estado. Similarmente, ao se depositar a ênfase valorativa na utopia e na revolução, obscurece-se a possibilidade de notar qualquer tipo de tendência evolutiva no domínio do histórico e do institucional. Segundo este ponto de vista, cada acontecimento histórico constitui uma libertação sempre renovada de uma topia (ordem existente), a qual é efetuada por uma utopia que surge a partir da primeira. Somente existe verdadeira vida na utopia e na revolução, a ordem institucional nada mais sendo do que o resíduo maligno deixado pelas utopias e revoluções em declínio. Dessa forma, o caminho da história vai de uma topia, por uma utopia, até a topia seguinte, etc.

A unilateralidade desta visão do mundo e desta estrutura conceitual é por demais evidente para requerer uma elaboração posterior. Seu mérito, entretanto, reside no fato de, em oposição 
à opinião "conservadora" que se pronuncia a favor da ordem estabelecida, evitar que a ordem existente se torne absoluta, ao contemplá-la como apenas uma das possíveis “topias” de que irão emanar os elementos utópicos que, por seu turno, irão solapá-la. Torna-se assim claro que, para encontrar a concepção correta de utopia, ou, mais modestamente, a mais adequada ao presente estágio de nosso raciocínio, deve a análise baseada na Sociologia do Conhecimento ser empregada para revelar a unilateralidade de cada uma destas posições antagônicas, eliminando-as. Tornar-se-á então claro aquilo em que exatamente consiste a particularidade das concepções precedentes. Somente depois de se haver esclarecido esta questão é que se torna possível, tomando por base o discernimento pessoal de cada um, atingir uma solução mais inclusiva, que supere a unilateralidade que "se tornou aparente. A concepção de utopia por nós utilizada parece neste sentido a mais inclusiva. Procura levar em conta o caráter dinâmico da realidade, na medida em que não assume como ponto de partida uma "realidade em si", mas, antes, uma realidade concreta, histórica e socialmente determinada, que se acha em um constante processo de mudança (cf. págs. 120 e segs. e pág. 150, nota 13). Além disso, propõe-se a atingir uma concepção de utopia qualitativa, histórica e socialmente diferenciada, e, finalmente, manter a distinção entre o "relativamente" e o "absolutamente utópico".

Tudo isso ocorre, em última análise, por ser nossa intenção não estabelecer apenas abstrata e teoricamente algum tipo de relação arbitrária entre a existência e a utopia, mas, antes, se possível, fazer justiça à plenitude concreta da transformação histórica e social da utopia em um dado período. Mais ainda, assim fazemos porque não apenas buscamos observar contemplativamente e descrever morfologicamente esta transformação de forma na concepção de utopia, mas também porque desejamos assinalar o princípio vital 
que vincula o desenvolvimento da utopia com o desenvolvimento de uma ordem existente. Neste sentido, a relação entre a utopia e a ordem existente aparece como uma relação "dialética". Queremos dizer com isso que cada época permite surgir (em grupos sociais diversamente localizados) as ideias e valores em que se acham contidas, de forma condensada, as tendências não-realizadas que representam as necessidades de tal época. Estes elementos intelectuais se transformam, então, no material explosivo dos limites da ordem existente. A ordem existente dá surgimento a utopias que, por sua vez, rompem com os laços da ordem existente, deixando-a livre para evoluir em direção à ordem de existência seguinte. Esta "relação dialética" já foi bem enunciada pelo hegeliano Droysen ainda que de uma maneira formal e intelectualista. Suas definições podem ser úteis para o esclarecimento inicial deste aspecto dialético. Assim, escreve ele: ${ }^{4}$

\section{$\$ 77$}

"Toda evolução no mundo histórico se processa da seguinte forma: O pensamento, que é a contrapartida ideal das coisas como estas existem na realidade, se desenvolve como as coisas deveriam ser..."

$\$ 78$

"Os pensamentos constituem a crítica do que é, sem no entanto ser como deveria ser. Na medida em que possam elevar as condições ao nível deles, alargandose depois e se enrijecendo de acordo com o costume, o conservadorismo e a obstinação, uma nova crítica se faz necessária, e assim por diante."

4 Droysen, T. G., Outline of the Principles of History, thay, por Benjamin Andrews, Boston, 1893, págs. 45-6. 


\section{$\int 79$}

"Que a partir de condições já dadas, surjam novos pensamentos e, a partir dos pensamentos, novas condições eis o trabalho dos homens."

Esta formulação da progressão dialética, da situação e das contradições a serem encontradas no domínio do pensamento deve ser encarada como apenas um esboço formal. $\mathrm{O}$ verdadeiro problema reside em se traçar o intercurso das formas diferenciadas de existência social com as diferenciações correspondentes nas utopias. Disso resulta que os problemas levantados se tornam mais sistemáticos e mais inclusivos, na medida em que refletem a riqueza e a variedade da história. O problema mais imediato para a pesquisa consiste em levar o sistema conceitual e a realidade empírica a um contato mais próximo um com o outro.

Aqui cabe a observação de que em geral o aparato conceitual 1 dos partidos progressistas se presta melhor ao estudo sistemático -- na medida em que sua posição social oferece possibilidades mais amplas para o pensamento sistemático. ${ }^{5}$ Por outro lado, os conceitos históricos que enfatizem a singularidade dos acontecimentos seriam tendencialmente produto dos elementos conservadores da sociedade. Pelo menos não pode haver dúvida quanto a exatidão desta imputação para a época em que surgiu a ideia de singularidade histórica, em oposição à de generalização.

Em consequência, podemos prever que o historiador irá criticar nossa definição de utopia como sendo uma construção por demais arbitrária, de um lado, por não se ter limitado ao tipo de obras cujos títulos foram retirados da Utopia de Thomas More, e,

5 Para as causas, ef. Meu das konservatice denken, op. Cit., pags. 83 e segs. 
de outro, por incluir muitas coisas não-relacionadas a este ponto de partida histórico.

Esta objeção se apoia na suposição mantida pelos historiadores de que a) sua única tarefa consiste na apresentação dos fenômenos históricos em toda a singularidade concreta pela qual se apresentam; e que b) portanto, deve-se trabalhar exclusivamente com conceitos descritivos, isto é, conceitos que, segundo um ponto de vista sistemático, não são definidos com uma rigidez tal que os impeça de respeitar o caráter fluido dos fenômenos. Portanto, os acontecimentos devem ser agrupados e classificados tomando se por base não um princípio de similaridade, mas antes na qualidade de fenômenos cuja relação pode ser descoberta (através de sinais perceptíveis), por se tratar de partes de uma situação histórica única. Claro está que quem se aproximar do estudo da realidade histórica com tais pressuposições irá obstruir, por meio de seu aparato conceitual, o caminho para a investigação sistemática. Concedendo-se que a história representa mais do que uma questão de concretude e de individualidade, e que possua alguma organização estrutural, chegando mesmo, até certo ponto, a seguir leis (uma suposição que deve ser mantida aberta como uma das possibilidades), como se poderia descobrir estes fatores com conceitos tão ingênuos que somente se referem a unicidade histórica? Um conceito ingênuo historicamente seria, por exemplo, o de "utopia", na medida em que, em sua utilização técnica histórica, compreendesse as estruturas que se assemelhassem em termos concretos à Utopia de Thomas More, ou que, em um sentido histórico algo mais amplo, se referissem às "comunidades ideais". Não pretendemos negar a utilidade de tais conceitos individualmente descritivos, uma vez que o objetivo seja a compreensão dos elementos individuais na história. Negamos, contudo, que seja esta a única abordagem aos fenômenos históricos. Neste caso, 
a pretensão dos historiadores de que a história, em si e para si, seja exatamente este encadeamento de fenômenos únicos não se coloca como um argumento contra nossa afirmação. Como poderia a história ser algo melhor quando, com o simples enunciado do problema e a formulação dos conceitos, já se fechasse a possibilidade de se alcançar qualquer outra resposta? Quando se aplique à história conceitos que não foram projetados para revelar estruturas, como podemos esperar chegar, por seu intermédio, a estruturas históricas? Se nossas indagações não antecipam um certo tipo de resposta teórica, como podemos esperar obtê-la? (Trata-se aqui de uma repetição, em nível mais elevado, do procedimento que tivemos a oportunidade de observar anteriormente, no caso dos conservadores e dos anarquistas: a possibilidade de uma determinada resposta indesejável já se acha bloqueada pela maneira pela qual se enuncia o problema e através da formulação dos conceitos a serem aplicados. Cf. págs. 219 e segs.)

Uma vez que a indagação que fazemos a história se destina, por sua própria natureza, a resolver o problema de existirem ou não ideias até então não concretizadas na realidade, que transcendam uma dada realidade, tais fenômenos podem ser enunciados como um complexo de problemas sob a forma de um conceito. Seria portanto coerente colocar a questão sobre se este conceito pode ser vinculado ao significado do termo "utopia". A questão permite uma resposta dupla; na medida em que definimos o termo, "utopia irá significar isto e isto...", ninguém poderá objetar nosso procedimento, porque admitimos que a definição foi proposta somente para determinados fins (como Max Weber viu perfeitamente). Quando, entretanto, além disso, vinculamos esta definição a conotação historicamente evoluída do termo, o fazemos com o propósito de mostrar que os elementos por nós enfatizados em nossa concepção da utopia já se achavam presentes nas utopias tal 
como estas apareceram na história. Por esta razão, somos da opinião de que nosso conceitos abstratos não são apenas construções intelectuais voluntárias e arbitrárias, mas possuem suas raízes na realidade empírica. Os conceitos que criamos existem não simplesmente para fins de especulação, mas para auxiliar na reconstrução das forças estruturais que se acham presentes na realidade, se bem que nem sempre evidentes. Uma abstração construtiva não é o mesmo que uma especulação onde nunca se vai além do conceito e da reflexão sobre ele. A abstração construtiva constitui um pré-requisito para a investigação empírica que, se preenche as antecipações implícitas no conceito ou, mais simplesmente, se fornece provas da exatidão do construto, confere ao último a dignidade de uma reconstrução.

Em geral, a antítese do procedimento histórico e da construção sistemática somente deve ser usada com o máximo cuidado. Nos estágios preliminares do desenvolvimento de uma ideia, pode ser realmente de algum auxílio para o esclarecimento. Quando, no decurso da evolução histórica desta antítese, assumiram relevância as ideias de Ranke, um bom número de diferenças se viu provisoriamente esclarecido pelo contraste entre os dois procedimentos. Por exemplo, o próprio Ranke estava preparado para esclarecer suas diferenças com Hegel. Se, a partir deste contraste, efetuamos uma antítese final e uma oposição absoluta que nos conduz para além da evolução histórica e da estrutura imanente dos fenômenos, mas que somente é legítima e útil como um primeiro passo no desenvolvimento de uma ideia, o resultado será que, como é tão frequente acontecer, estaremos incorrendo na falha de tornar absoluto o que nada mais e' que um estágio isolado no desdobramento de uma ideia. Também aqui o absolutismo bloqueia o caminho 
para a síntese das abordagens sistemática e histórica, obstruindo a compreensão da situação total. ${ }^{6}$

Devido a que a determinação concreta do que seja utópico procede sempre de um certo estágio de existência, é possível que as utopias de hoje venham a ser as realidades de amanhã:"Muitas vezes as utopias nada mais são do que verdades prematuras" ("Les utopies ne sont souvent que desertes prématurées", segundo Lamartine). Sempre que uma ideia for rotulada de utópica, geralmente o autor deverá ser um representante de uma época que já tenha passado. Por outro lado, a revelação das ideologias como sendo ideias ilusórias, que se adaptam a presente ordem, será geralmente trabalho de representantes de uma ordem de existência que ainda se encontra em processo de emergência. Será sempre o grupo dominante, que esteja em pleno acordo com a ordem existente, quem irá determinar o que se deve considerar utópico, ao passo que o grupo ascendente, em conflito com as coisas como estão, determinará o que deve ser considerado ideológico. Outra dificuldade em definir com precisão o que se deve, em um dado período, considerar ideologia e o que se deve considerar como utopia resulta do fato de os elementos ideológicos e utópicos não ocorrerem separadamente no processo histórico. As utopias das classes ascendentes se acham frequentes vezes permeadas por elementos ideológicos.

6 Quanto aos perigos práticos da conceituação histórica, cf. a crítica de Meinecke por Schmitt: "Zu Friedrich Meineckes Idee der Staatsriason", Archiv fur Sozialwissenschaft und Sozialpolitik (1926), LVI, págs. 226 e segs. É lamentável que os problemas decorrentes da controvérsia entre estes dois típicos representantes de seus respectivos pontos-de-vista não tenham sido mais amplamente elaborados na literatura. Com respeito ao problema da relação entre história e sistema-tização, cf. Sombart, W., "Economic Theory and Economic History", Economic History Review, II, n. ${ }^{\circ} 1$, janeiro, 1929; jecht, H» wirtschaftSgcschichte und Wirtschaftstheorie (Tubingen, 1928). 
A utopia da burguesia ascendente consistia na ideia da "liberdade". Era em parte uma verdadeira utopia, isto é, continha elementos orientados para a realização de uma nova ordem social, constituindo um instrumento para a desintegração da ordem previamente existente, e que, após sua realização, se converteram parcialmente em realidade. Liberdade no sentido de quebrar as cadeias da ordem de estado, guilda e casta, no sentido de liberdade de pensamento e de opinião, no sentido de liberdade política e liberdade do desenvolvimento sem entraves da personalidade, tornaram-se em um sentido amplo, ou pelo menos em um sentido mais amplo do que na sociedade feudal anterior baseada nos laços de status, uma possibilidade viável. Sabemos, hoje em dia, exatamente em que medida estas utopias se tornaram realidades e até que ponto a ideia de liberdade daquela época continha não apenas elementos utópicos, mas igualmente elementos ideológicos.

Onde quer que a ideia de liberdade tivesse que fazer concessões à ideia concomitante de igualdade, estava colocando objetivos em contradição com a ordem social que requeria e que mais tarde se realizou. A separação dos elementos ideológicos da mentalidade burguesa dominante dos capazes de realização subsequente, isto é, os elementos verdadeiramente utópicos, somente poderia ser efetuada por um estrato social que mais tarde se apresentasse em cena para desafiar a ordem existente.

Todas as incertezas por nós assinaladas como estando implicadas em uma definição específica do que seja utópico e do que seja ideológico na mentalidade de uma dada época tornam de fato mais difícil a formulação do problema, mas não impedem sua investigação. Somente quando nos encontramos no verdadeiro centro de ideias mutuamente conflitantes é que se torna extremamente difícil determinar o que se deve considerar 
verdadeiramente utópico (isto é, viável no futuro) no horizonte de uma classe em ascensão e o que se deve considerar meramente como a ideologia de classes dominantes, bem como de classes ascendentes. Mas, se olharmos para o passado, parece possível encontrar um critério razoavelmente adequado para a distinção entre o utópico e o ideológico. Tal critério é sua realização. Ideias que posteriormente se mostraram como tendo sido apenas representações destorcidas de uma ordem social passada ou potencial eram ideológicas, enquanto as que foram adequadamente realizadas na ordem social posterior eram utopias relativas. As realidades atualizadas do passado põem um termo ao conflito de metas opiniões sobre o que, nas ideias situacionalmente transcendentes de antigamente, era relativamente utópico, rompendo os laços da ordem existente, e o que era uma ideologia, servindo únicamente para dissimular a realidade. A extensão em que as ideias são realizadas constitui um padrão complementar e retroativo para estabelecer distinções entre fatos que, na medida em que são contemporâneos, se acham imersos no conflito de opiniões partidárias.

\section{Realização de desejos e mentalidade utópica}

O pensamento desiderativo sempre figurou nos assuntos humanos. Quando a imaginação não encontra sua satisfação na realidade existente, busca refúgio em lugares e épocas desiderativamente construídos. Mitos, contos de fada, promessas supra terrenas da religião, fantasias humanísticas, romances de viagens têm sido expressões, em contínua mutação, do que estava faltando na vida real. Constituíam, mais precisamente colorações complementares do retrato da realidade da época do que utopias atuando em oposição ao status quo, e desintegrando-o. 
Uma extraordinária pesquisa na história cultural ${ }^{7}$ demonstrou que as formas de aspirações humanas podem ser enunciadas em termos de princípios gerais e que, em determinados períodos históricos, a consecução de desejos se produzia através da projeção no tempo, ao passo que, em outros, se realizava através da projeção no espaço. De acordo com esta diferenciação seria possível chamar de utopias os desejos espaciais, e de quiliasmas, os desejos temporais. Esta definição de conceitos, segundo os interesses da história cultural, objetiva apenas princípios descritivos. Não podemos, entretanto, aceitar a distinção entre projeção de desejos espacial e temporal como um critério decisivo para diferenciar tipos de ideologias e utopias. Consideramos utópicas todas as ideias situacionalmente transcendentes (não apenas projeções de desejos) que, de alguma forma, possuam um efeito de transformação sobre a ordem histórico-social existente. Sendo este o passo inicial de nossa investigação, vemo-nos diante de uma série de problemas.

Já que, sob este aspecto, nos interessamos inicialmente pelo desenvolvimento da vida moderna, nossa primeira tarefa consiste em descobrir o momento em que as ideias situacionalmente transcendentes se tornam pela primeira vez ativas, isto é, se tornam forças que conduzem à transformação da realidade existente. Seria

7 Doren, A., Wunschraume und Wunschzeiten (Conferências, 1924-5, da Biblioteca Warburg, Leipzig, Berlim, 1927, págs. 158 e segs.). Esta obra é citada para futura referência Como o melhor guia para o tratamento do problema do ponto de vista da história cultural e da história das ideias. Contém, igualmente, uma excelente biografia. No presente trabalho, citamos somente aquelas obras que não aparecem nas referências bibliográficas do livro de Doren. O ensaio de Doron pode ser classificado como uma história do motivo (algo semelhante à iconografia na história da arte). Para tal finalidade, sua terminologia ("aspiração espacial" e "aspiração temporal") é particularmente apropriada, mas para nosso propósito, isto é, a construção de uma história sociológica da estrutura da moderna consciência, tem apenas valor indireto. 
conveniente indagar aqui qual dos elementos situacionalmente transcendentes na mentalidade dominante, em diferentes épocas, assumiu esta função ativa. Pois na mentalidade humana nem sempre são as mesmas forças, substâncias ou imagens

As que podem adotar uma função utópica, ou seja, a função de romper os laços da ordem existente. Veremos em seguida que o elemento utópico em nossa consciência está sujeito a mudanças de conteúdo e forma. A situação existente, em qualquer momento dado, acha-se constantemente abalada por diferentes fatores situacionalmente transcendentes.

Esta mudança de substância e forma da utopia não ocorre em um campo independente da vida social. Seria possível demonstrar que, pelo contrário, especialmente em desenvolvimentos históricos modernos, as sucessivas formas de utopia se acham, no início. Intimamente vinculadas a dados estágios históricos de desenvolvimento e, em cada um destes, a particulares estratos sociais. Ocorre com grande frequência que a utopia dominante surja inicialmente como a quimera de um único indivíduo, somente mais tarde incorporada nos objetivos políticos de um grupo mais inclusivo que. a cada estágio sucessivo, pode ser sociologicamente determinado com maior exatidão. Costuma-se falar em tais casos de um precursor e do seu papel como pioneiro, atribuindo-se esta realização individual, em termos sociológicos, ao grupo a que transmitiu sua visão e em cujo benefício concebeu tais ideias. Isto implica a suposição de que a aceitação ex post fato da nova visão por determinados estratos apenas evidencia o impulso e as raízes sociais da concepção de que o precursor ja participava inconscientemente e de onde extraiu a tendência geral de sua realização, de outra forma indiscutivelmente individual. A crença de que a significação do poder individual de criação deve ser negada constitui um dos mais generalizados a respeito das descobertas da Sociologia. Pelo 
contrário, de onde se poderia esperar que o novo se originasse a não ser do espírito novo e singularmente pessoal do indivíduo que ultrapassa os limites da ordem existente? Constitui tarefa da Sociologia mostrar sempre que, não obstante, os primeiros indícios do que é novo (muito embora com frequência adotem a forma de oposição à ordem existente) se acham de fato orientados para a ordem existente e que a própria ordem existente possui suas raízes no alinhamento e na tensão das forças da vida social. Mais ainda, o que é novo na realização do indivíduo "carismático" singular somente pode ser utilizado para a vida coletiva quando, desde o início, se acha em contato com algum problema corrente importante e quando seus significados estão geneticamente enraizados nos objetivos coletivos. Não devemos, contudo, superestimar a significação da importância do indivíduo em relação à coletividade, como nos acostumamos a fazer desde a Renascença. Desde esta época, a contribuição da mente individual se eleva relativamente quando comparada ao papel que desempenhou durante a Idade Média e nas culturas orientais, mas sua significação não é absoluta. Mesmo quando um indivíduo aparentemente isolado atribui uma forma a utopia de seu grupo, este fato pode ser, em última análise, atribuído ao grupo a cujo impulso coletivo sua realização se conformou.

Após havermos esclarecido as relações entre as realizações do indivíduo e as do grupo, achamo-nos em condições de falar de uma diferenciação de utopias de acordo com épocas históricas e estratos sociais, e de encarar a história segundo este ponto de vista. No sentido de nossa definição, uma utopia real não pode, a longo prazo, ser trabalho de um indivíduo, já que o indivíduo não pode por si mesmo romper a situação histórica e social. Somente quando a concepção utópica do indivíduo se impõe a correntes já existentes na sociedade, dando-lhes uma expressão, quando, sob 
esta forma, reflui de volta ao horizonte de todo o grupo, sendo por este traduzida em ação, somente então pode a ordem existente ser desafiada pela luta por outra ordem de existência. Com efeito, pode-se constatar, ainda mais, que se trata de uma dimensão bastante essencial da história moderna o fato de que, na gradativa organização da ação coletiva, as classes sociais somente se tornam eficientes na transformação da realidade histórica quando suas aspirações se encontram encarnadas em utopias apropriadas para a situação em mudança.

Somente porque existiu uma estreita correlação entre as diferentes formas de utopia e os estratos sociais que estavam transformando a ordem existente é que as mudanças nas ideias utópicas modernas constituem um tema de investigação sociológica. Se podemos falar de diferenciações históricas e sociais de ideias utópicas, devemos então nos indagar se a forma e a substância que em uma dada época possuíram não deveriam ser compreendidas através de uma análise concreta da situação histórico-social em que surgiram. Em outras palavras, a chave para a inteligibilidade das utopias consiste na situação estrutural do estrato social que, em um dado tempo, as espose.

As peculiaridades das formas particulares utopias em sucessiva emergência tornam-se de fato mais proximamente inteligíveis, caso não as consideremos meramente em termos de filiação unilinear de uma para a outra, e, sim, levando em conta o fato de que vieram a existir e se mantiveram como contra-utopias em mútuo antagonismo. As diferentes formas das utopias ativas apareceram nesta sucessão histórica em vinculação com determinados estratos sociais definidos em luta pela supremacia. Apesar de frequentes exceções, esta vinculação continuou a existir de modo que, com o passar dos tempos, se torna possível falar de uma coexistência das diferentes formas de utopia que inicialmente apareciam em 
uma sucessão temporal. $\mathrm{O}$ fato de existirem em íntima vinculação, às vezes latente, às vezes manifesta, com estratos mutuamente antagônicos, reflete-se na forma que assumem. A mudança de destino das classes a que pertencem constantemente se expressa nas variações concretas na forma das utopias. O fato básico de precisarem se orientar umas às outras por meio do conflito, ainda que se trate apenas do sentido de oposição, deixa sobre elas uma marca definitiva. Em consequência, o sociólogo somente pode realmente compreender estas utopias como fazendo parte de uma constelação total em constante alteração. ${ }^{8}$

Se a história social e intelectual se preocupasse exclusivamente com o fato anteriormente delineado de que cada forma de ideologia socialmente vinculada está sujeita a mudança, só teríamos o direito de falar de problemas que dissessem respeito à transformação socialmente vinculada da "utopia", mas não do problema da transformação da "mentalidade utópica". Somente se poderá falar corretamente de uma mentalidade utópica quando a configuração da utopia, em qualquer época, constitua não apenas uma parte vital do "conteúdo" da mentalidade em questão, mas quando pelo menos permeie, em sua tendência geral, todo o campo desta mentalidade. Somente quando o elemento utópico, neste sentido, tenda a se infundir completamente em cada aspecto da mentalidade dominante na época, quando as formas de experiência, de ação e de visão (perspectiva) estejam organizadas em concordância com este elemento utópico, estaremos verdadeira e realisticamente no direito de falar não apenas de diferentes formas de utopia, mas, ao mesmo tempo, de diferentes configurações e

8 É mérito de Alfred weber o ter feito desta análise de constelações um instrumento da Sociologia Cultural. Tentamos aplicar tal formulação de problema, embora num sentido especifico, ao caso acima tratado. 
estágios de mentalidade utópica. E é exatamente esta tarefa de provar que tal inter-relação profunda realmente existe que constitui a culminação de nossa pesquisa.

O elemento utópico - isto é, a natureza do desejo dominante - determina a sequência, a ordem e a valoração das experiências singulares. Este desejo constitui o princípio organizador que modela a própria maneira pela qual experimentamos o tempo. A forma em que os acontecimentos se acham ordenados e o ritmo inconscientemente enfático que o indivíduo, em sua observação espontânea dos acontecimentos, impõe ao fluxo do tempo, aparece na utopia como um quadro imediatamente perceptível ou, pelo menos, como um conjunto de significações diretamente inteligíveis. A estrutura interna da mentalidade de um grupo nunca pode ser mais claramente captada do que quando tentamos compreender sua concepção do tempo à luz de suas esperanças, aspirações e propósitos. Com base nestes propósitos e expectativas, uma dada mentalidade ordena não só os acontecimentos futuros, mas também os passados. Acontecimentos que à primeira vista se apresentam como uma mera acumulação cronológica, assumem, segundo este ponto de vista, o caráter de destino. Os simples fatos se colocam em perspectiva, distribuindo-se e parcelando-se ênfases de significação a eventos isolados de acordo com as direções fundamentais buscadas pela personalidade, Não é senão nesta significativa ordenação de acontecimentos, prolongando-se muito além das meras ordenações cronológicas, que se irá descobrir o princípio estrutural do tempo histórico. Mas é necessário ir ainda mais além: esta ordenação de significados constitui, na verdade, o elemento mais importante na compreensão e na interpretação dos acontecimentos. Assim como a Psicologia moderna demonstra que o todo (Gestalt) cede as partes, e que nossa primeira compreensão das partes surge através do todo, da mesma forma sucede com a 
compreensão histórica. Também aqui temos o sentido do tempo histórico como uma totalidade significativa que ordena os acontecimentos "anteriormente" às partes, e através desta totalidade é que verdadeiramente compreendemos pela primeira vez o curso total de acontecimentos e nosso lugar nele. Exatamente devido a esta significação central do sentido de tempo histórico, iremos enfatizar em especial as conexões existentes entre cada utopia e a correspondente perspectiva histórica de tempo.

Quando nos referimos a certas formas e estágios da mentalidade utópica, temos em mente estruturas de mentalidade concretas e possíveis de serem descobertas, tais como encontráveis em seres humanos vivos e individuais. Não estamos pensando neste momento em alguma unidade construída de maneira puramente arbitrária (como a "consciência em si" de Kant) ou uma entidade metafisica a ser colocada além das mentes concretas dos indivíduos (como no "espírito" de Hegel). Antes nos referimos às estruturas de mentalidade concretamente possíveis de serem descobertas, tais como podem ser demonstradas a partir dos indivíduos. Portanto estaremos aqui preocupados com o pensar, agir e sentir concretos e com suas conexões internas em tipos concretos de homens. Os tipos puros e estágios da mente utópica somente constituem construções na medida em que são concebidos como tipos-ideais. Nenhum indivíduo isolado representa a encarnação pura de qualquer um dos tipos de mentalidade histórica e social aqui apresentados. ${ }^{9}$ Antes, em cada indivíduo concreto e isolado existiriam em atuação determinados elementos de um certo tipo de estrutura mental, muitas vezes misturados com outros tipos.

9 Cf. subtítulo I da parte II e subtítulo II desta parte IV. 
Quando então analisarmos os tipos ideais de mentalidades utópicas em suas diferenciações históricas e sociais, não as propomos como construções epistemológicas ou metafísicas. Trata-se simplesmente de recursos metodológicos. Nenhuma mente individual, tal como existiu efetivamente, correspondeu plenamente aos tipos e suas interconexões internas, que serão descritos. Contudo, cada mente individual, em sua concretude, tende (apesar de todas as mesclagens) a se organizar geralmente segundo as linhas estruturais de um destes tipos historicamente cambiantes. Estas construções, assim como os tipos ideais de Max Weber, apenas servem para o domínio sobre as complexidades passadas e presentes. Em nosso caso, foram além disso propostas para a compreensão não apenas de fatos psicológicos, mas também para a compreensão, em toda a sua "pureza", das estruturas que neles se desdobram e atuam historicamente.

\section{Mudanças na configuração da mentalidade utópica: seus estágios nos tempos modenos}
a) A Primeira Forma da Mentalidade Utópica: O Quiliasma Orgiástico dos Anabatistas

A mudança decisiva na história moderna foi, sob o ponto de vista do nosso problema, o momento em que o "Quiliasma" uniu suas forças às demandas ativas dos estratos oprimidos da sociedade. ${ }^{10} \mathrm{~A}$ ideia da aurora de um reinado milenar sobre a terra sempre

10 Fixar o início de um movimento num ponto dado da sequência de eventos históricos é sempre perigoso e implica fazer caso omisso dos precursores do movimento. Mas a reconstrução bem sucedida do que é mais essencial no desenvolvimento histórico depende da habilidade do historiador em dar a ênfase apropriada aos pontos cruciais decisivos na articulação dos fenômenos. 
conteve uma tendência revolucionarizante, e a Igreja fez todos os esforços para paralisar esta ideia situacionalmente transcendente com todos os meios de que dispunha. Estas ideias, que intermitentemente afloravam, reapareceram novamente em Joachim das Flores, entre outros, mas neste caso ainda não se cogitava delas como revolucionárias. Entretanto, entre os hussitas e depois em Thomas Munzer ${ }^{11}$ e os Anabatistas estas ideias se transformaram nos movimentos ativadores de estratos sociais específicos. Aspirações que até então não se haviam apegado a um objetivo específico, ou se concentravam em objetivos extraterrenos, assumiram subitamente uma compleição mundana. Sentia-se que eram viáveis - aqui e agora -e infundiam um ardor singular à conduta social.

A “espiritualização da política", de que se pode dizer que começou neste momento da história, afetou em maior ou menor escala todas as correntes da época. A origem da tensão espiritual estava, porém, na emergência da mentalidade utópica originada

O fato de o socialismo moderno frequentemente reportar suas origens ao tempo dos anabatistas demonstra, em parte, que o movimento liderado por Thomas Munzer deve ser tido como um passo em direção aos movimentos revolucionários modernos. É óbvio, naturalmente, que não estamos lidando aqui com proletários com consciência de classe. Do mesmo modo, deve ser desde logo aceito que Munzer era um revolucionário social por motivos religiosos. Contudo, o sociólogo deve dar particular atenção a este movimento, porquanto nele o quiliasma e a revolução social estão estruturalmente integrados.

11 Das obras sobre Munzer citamos apenas K. Holl, "Luther und die Schwarmer" (Gesammelte Aufsatze zur Kirchengeschichte, Tulbingen, 1927, págs. 420 e segs.), onde estão admirávelmente reunidas citações, em grande número, sobre um mesmo problema. Nas referências que se seguem, simplesmente citaremos a passagem em Holl, sem a citar detalhadamente.

Para a caracterização do quiliasma, cf. especialmente Bloch, E., Thomas Munzer als Theologe der Revolution (Munique, 1921). Uma afinidade íntima entre Munzer e este autor tornou possível uma exposição muito adequada da essência do fenômeno do quiliasma. Este já fora em parte corretamente avaliado por Doren, Op. cit. 
nos estratos oprimidos da sociedade. É neste ponto que tem início a política, no sentido moderno do termo, se entendermos por política uma participação mais ou menos consciente de todos os estratos da sociedade na consecução de alguma finalidade mundana, em contraste com a aceitação fatalista dos acontecimentos como são ou com a do controle de "cima". ${ }^{12}$

No período pós-medieval, somente muito gradativamente foram as classes mais baixas assumindo esta função motora no processo social total e atingindo uma consciência de sua própria importância política e social. Muito embora este estágio, como já indicamos, se ache ainda bem distante do da "autoconsciência proletária", não obstante constitui o ponto de partida deste processo. Desde então as classes oprimidas da sociedade tendem, de uma forma mais claramente discernível, a desempenhar um papel específico no desenvolvimento dinâmico do processo social total. A partir desta época encontramos uma crescente diferenciação social de propósitos e de atitudes psíquicas.

Isto não implica de forma alguma que esta forma mais extrema de mentalidade utópica tenha sido o único fator determinante da história desde essa época. Não obstante, sua presença no campo social tem exercido uma influência quase contínua até sobre as mentalidades antitéticas. Mesmo os opositores desta forma extrema de mentalidade utópica se orientaram, embora involuntária e inconscientemente, com referência a ela. A visão utópica provocou uma visão contrária. O otimismo quiliástico dos revolucionários

12 A política pode, evidentemente, ser definida de várias maneiras. NCNU' caso, novamente, devemos reiterar o anteriormente afirmado: a definição está sempre relacionada à sua finalidade e ao ponto de vista do observador. Nossa finalidade, aqui, é traçar a relação entre a formação da consciência coletiva e a história política, e, consequentemente, nossa definição, que seleciona certos fatos, deve ser relacionada \& tal formulação do problema 
veio finalmente a dar origem à formação da atitude conservadora de resignação e, na política, à atitude realista.

Esta situação foi de grande importância não só para a política, mas igualmente para as tendências espirituais que se haviam fundido com os movimentos práticos e que tinham abandonado sua posição desvinculada e afastada. Energias orgásticas e irrupções extáticas começaram a operar em um quadro terreno e as tensões que anteriormente transcendiam a vida cotidiana se tornaram agentes explosivos dentro do todo-o-dia. O impossível faz nascer o possível, ${ }^{13}$ ao e o absoluto interfere no mundo e condiciona os acontecimentos efetivos. Esta forma fundamental, a mais radical de utopia moderna, foi conformada a partir de um material singular. Correspondeu a fermentação espiritual e ao excitamento físico dos camponeses, de um estrato que vivia o mais próximo da terra. Era ao mesmo tempo robustamente material e altamente espiritual.

Nada seria mais enganoso do que tentar entender estes acontecimentos sob o ponto de vista da "história das ideias". Ideias não impeliram estes homens a feitos revolucionários. Sua explosão efetiva era condicionada por energias extático-orgiásticas. Os elementos da consciência transcendentes à realidade, que foram aqui despertados para uma função utópica ativa, não eram "ideias". Ver tudo o que ocorreu durante este período como o trabalho de "ideias" constitui uma deformação inconsciente produzida durante o estágio liberal-humanitário da mentalidade utópica. ${ }^{14} \mathrm{~A}$ história das ideias foi a criação de uma época marcada pela ideia, que reinterpretava involuntariamente o passado à luz de suas próprias experiências centrais. Não foram as "ideias" que impeliram

13 O próprio Munzer falava de "coragem e vigor para realizar o impossível". Para citações, cf. Holl, pág. 429.

14 Questão a ser discutida na próxima seção. 
os homens, durante as Guerras Camponesas, à ação revolucionária. Esta erupção tinha suas raízes em níveis bem mais elementares e mais profundamente vitais da psique. ${ }^{15}$

Se quisermos aproximar-nos de um entendimento da verdadeira substância do Quiliasma, possibilitando o acesso a sua compreensão científica, impõe-se antes de mais nada distinguir entre Quiliasma e as imagens, símbolos e formas com os quais pensava a mente quiliástica. Pois em nenhuma outra ocasião nossa experiência será tão válida quanto aqui no que ao fato de que o que já se encontre formado e a expressão assumida pelas coisas tendem a se desligar de suas origens e a prosseguir seu próprio caminho independentemente dos motivos que as inspiraram. A dimensão essencial do Quiliasma reside em sua tendência a sempre se dissociar de suas imagens e símbolos. Justamente porque a força impulsionadora desta utopia não se situa na forma de sua expressão externa é que uma visão do fenômeno baseada na mera história de ideias deixa de lhe fazer justiça. Tal visão se arrisca constantemente a perder o ponto essencial. Se utilizarmos os métodos da história das ideias tenderemos a colocar no lugar da história da substância do Quiliasma a história dos quadros de referência que já se esvaziaram de conteúdo, isto é, a história das meras ideias quiliásticas em si mesmas. ${ }^{16}$ De modo semelhante, a investigação das carreiras dos revolucionários quiliásticos resulta enganosa, uma vez que pertence à natureza da experiência quiliástica refluir ao

15 Munzer refere-se ao "abismo d espirito", que só pode ser visto quando as forças da alma se põem a descoberto. Cf. Holl. Pág. 428. Nota 6.

16 No conflito entre Munzer e Lutero, há provas da supramencionada divergência sobre a ênfase a ser dada a fé, que pode ser tão-só ser experimentada, e as "ideias" que a simbolizam. Segundo Munzer, tal fé é uma "paródia simiesca, furtada, nunca experimentada”. Citações em Holl. Pág. 427. 
curso do tempo e sofrer uma irremediável transformação ao longo das experiências pessoais. Portanto, a fim de nos apegarmos firmemente ao próprio tema da investigação, devemos buscar um método de pesquisa que propicie uma percepção viva do material e que o apresente como se nós mesmos o estivéssemos vivendo. Devemos constantemente nos indagar se a própria atitude quiliástica se encontra efetivamente presente nas formas de pensamento e experiência com que num dado caso estejamos lidando.

A única característica identificadora, talvez a única que seja direta, da experiência quiliástica é a da atualidade absoluta. Sempre ocupamos algum lugar aqui e agora nos níveis temporal e espacial, mas segundo o ponto de vista da experiência quiliástica a posição que ocupamos é meramente acidental. Para o verdadeiro quiliasta, o presente vem a ser a fenda pela qual o que anteriormente quedava interrorizado irrompe subitamente, toma posse do mundo exterior e o transforma.

O místico vive na rememoração do êxtase ou na sua expectativa. Suas metáforas descrevem este êxtase como uma situação psíquica inconcebível em termos espaciais e temporais como uma união com o mundo fechado do além. É talvez esta mesma substância extática que, para o quiliasta, se torna um aqui e agora imediato, mas para unicamente o deleitar, mas a fim de arrebatá-lo e dele fazer uma parte de si mesmo. Thomas Munzer, o profeta quiliasta, assim. se exprimiu;"Por esta razão, todos os profetas deveriam falar da seguinte forma: "Assim fala o Senhor, e não "Assim falava o Senhor' como se tivesse ocorrido mais no passado do que no presente." ${ }^{17}$

17 Meister Eckehart: "Nada afasta mais a alma do conhecimento de Deus que o tempo e o espaço" (Meister Eckehart, Schriften und Predigten, ed. por Buttner (Iena, 1921, 1, pág. 137). "Se a alma quiser perceber Deus, deve situar-se acima 
A experiência do místico é puramente espiritual, e se há alguns traços de experiência sensorial em sua linguagem isto se deve a que ele tem de exprimir um contato espiritual inexprimível e somente pode encontrar seus símbolos nas analogias sensoriais da vida cotidiana. Entretanto, com o quiliasta a experiência sensorial se acha presente em toda a sua pujança, sendo tão inseparável da espiritualidade nele existente quanto ele se acha de seu presente imediato. Seria como se através deste presente ${ }^{18}$ imediato ele tivesse pela primeira vez vindo ao mundo e entrado em seu próprio corpo.

\section{Para citar o próprio Münzer:}

"Busco apenas que aceiteis a palavra viva em que vivo e respiro, de modo que ela não a mim não retorne vazia. Levai-a ao coração, eu vos conjuro pelo nome do rubro sangue de Cristo. Tomo conhecimento de vós e desejo dar-vos o conhecimento de mim. Se não puder ser assim,

do tempo e do espaço!" (Ibid., pág. 138). "Se a alma consegue superar-se e negar-se, a si e a suas antividades, só o faz pela graça” (I, 201). Para a distinção entre o misticismo medieval e a religiosidade de Munzer, cf. o pertinente comentário de Holl. "Enquanto os místicos da Idade Média se preparavam para Deus por meios artificiais, pelo ascetismo, e, por assim dizer, tentavam forçar a união com a divindade, Münzer acreditava que é 'o próprio Deus quem toma a foice para cortar as ervas daninhas de entre os homens"”(cf. Holl, pág. 483).

18 Münzer se expressa similarmente na seguinte passagem: "Ele deveria saber que Deus está dentro dele e que não se deveria pensar em Deus como se estivesse a mil milhas de distância" (Holl, pág. 430, nota 3). Em outra citação, aparece o radicalismo religioso de Munzer na distinção que faz entre o Cristo doce como mel e o Cristo amargo. Münzer acusou Lut ero de representar apenas o primeiro. (Holl, págs. 426-7.) Para a interpretação, cf. Bloch, op. cit., págs. 251 e segs. 
seja eu o filho da morte temporal e eterna. Não vos posso oferecer penhor mais alto." ${ }^{19}$

O quiliasta espera uma união com o presente imediato. Por isso, não se acha preocupado, em sua vida diária, com esperanças otimistas quanto ao futuro ou com reminiscências românticas. Sua atitude se caracteriza por uma tensa expectativa. Está sempre de pé, esperando o momento propício, não havendo portanto nenhuma articulação interna do tempo para ele. Não se acha realmente preocupado com o milênio que há por vir; ${ }^{20}$

$19 \mathrm{Na}$ arte criadora da época, representada pela pintura de Grünewald, pode-se encontrar, levado a um extremo grandioso, um paralelo desta íntima função do mais forte sensualismo com a mais elevada. espíritualidade. Porque se conhece muito pouco de sua vida, é impossível determinar se ele tinha ligações com os anabatistas. A referência a Grünewald contudo, pretende apenas ilustrar o que foi dito acima. (Cf, heidrich, E., Die altdeutche Malerei (lena, 1909), págs. 39-41, 269).

Cf. tambem a instrutiva obra de Heidrich, Dürer und die Reformation (Leipzig, 1909), na qual ele mostra claramente a relação demonstravel entre os entusiastas extáticos e seus seguidores entre Os pintores Hans Sebald, Barthel Beham e Georg Pencz, em Nuremberg, e a defesa de Durer contra eles. Heidrich vê. na arte de Durcr a expressão da religiosidade luterana, e na de Crunewald, o paralelismo com os entusiastas do êxtase religioso.

20 “" Munzer: "que nós, criaturas de carne e osso, deveríamos tornar-nos Deuses graças à Encarnação do Cristo, e, assim, convertermo-nos com Ele em discípulos de Deus, ensinados por ele (: em Seu espírito, tornados divinos e totalmente transformados n'Ele, e esta vida terrena tornar-se-ia o paraíso". (Citação em Holl, pág. 4531, nota 1.)

A propósito da sociologia da interiorização das experiências e, em geral, da teoria das relações das formas de experiência com as formas da atividade política pública, deve Ser notado que, à medida que Karlstadt e os batistas do Sul da Alemanha se afastaram de Munzer, tornaram-se mais e mais afastados da experiência quiliastiea da imediação, orientando-sc para a experiência profética e para uma esperança otimista DO futuro (Cf. Holl, Pág. 458). 
O que para ele tem importância é que isto se produza aqui e agora, e que tenha surgido da existência terrena, como se fosse um rápido volteio noutra espécie de existência. A promessa de um futuro que virá não constitui para ele uma razão para o adiamento, mas apenas um ponto de orientação, algo de externo ao curso normal dos acontecimentos, onde ele se encontra à espreita, pronto para se lançar.

Devido à peculiaridade de sua estrutura, a sociedade medieval e feudal não conheceu uma revolução no sentido moderno. ${ }^{21}$ “ Desde o aparecimento desta forma de mudança política, o quiliasma tem sempre acompanhado as eclosões revolucionárias, emprestando-lhes seu espírito. Quando este espírito reflui e abandona tais movimentos, permanece no mundo, e em seu rastro, um frenesi da massa e uma fúria desespiritualizada. O quiliasma encara a revolução como um valor em si mesmo, não como um meio inevitável de se atingir um fim racionalmente estabelecido, mas como o único princípio criador do presente imediato, como a esperada realização de suas aspirações neste mundo. "A vontade de destruir e' uma vontade criadora", dizia Bakunin, ${ }^{22}$ devido ao demônio

21 Uma das características da moderna revolução, estudada por Stahl, consiste em que ela não é um levante comum contra um opressor determinado, mas um esforço por um levante contra toda a ordem social existente, de forma sistemática e completa. Se tomarmos esta forma sistemática como o ponto de partiria da análise e estudarmos seus antecedentes históricos e intelectuais, chegaremos, neste caso, também ao quíliasma. Não obstante a-sistemático em muitas outras questões, o quiliasma, cm certa fase, manifestou tendências para a orientação sistemática abstrata. Assim, por exemplo, Radványi indicou que o quilíasma não atacava os indivíduos, mas só perseguia o princípio ativo do mal nos indivíduos e nas instituições. (Cf. sua dissertação não-publicada, Der Chiliasmus, Heidelberg, 1923, pág. 98). Outras citações em Holl, pág. 454

22 A literatura sobre Bakunin é citada adiante. Demonstraremos, mais tarde, que o anarquismo de Bakunin é o que, em nosso entender, mais se aproxima, em visão, da continuidade do quiliasma no mundo moderno. 
que o possuía, o Satã de que gostava de dizer que trabalhava por contágio. Que ele não estivesse fundamentalmente interessaria na realização de um mundo racionalmente concebido e' o que se depreende desta afirmação: "Não acredito em constituições ou leis. A melhor constituição me deixaria insatisfeito. Precisamos de algo diverso. De tempestade e de vitalidade e de um novo mundo sem leis e consequentemente livre."

Sempre que o espírito extático se fatiga de amplas perspectivas e de imagens, encontramos um reaparecimento da promessa concreta de um mundo melhor, embora isto não deva de forma alguma ser tomado em um sentido totalmente literal. Para esta mentalidade, as promessas de um mundo melhor distante no tempo e no espaço se assemelham a cheques indescontáveis -- sua única função é de fixar o ponto do "mundo além dos acontecimentos" de que falávamos, do qual quem estiver esperando ansiosamente o momento propício possa assegurar-se da separação face ao que se ache meramente em processo de vir a ser. Não estando de acordo com quaisquer acontecimentos que transpareçam no "mal" aqui e agora, espera apenas a junção crítica dos acontecimentos e o momento em que a concatenação externa das circunstâncias coincida com a inquietação extática de sua alma.

Em consequência, ao observarmos a estrutura e o curso do desenvolvimento da mentalidade quiliástica, é de muito pouca importância (embora para a história das variações em motif talvez seja significativo) que no lugar de uma utopia temporal tenhamos uma utopia espacial, e que na Idade da Razão e do Iluminismo o sistema fechado de dedução racional venha a permear o horizonte utópico. Em um certo sentido, o ponto de partida axiomático e racional, o sistema fechado de procedimento dedutivo, e o equilíbrio internamente verificado dos motivos compreendidos no 
corpo de axiomas, são tão capazes de infundir esta coerência interna e este isolamento do mundo quanto os sonhos utópicos. ${ }^{23}$

Além do mais, o que de forma meramente racional é correto e válido está tão afastado do tempo e do espaço que tal afastamento conduz a um reino estranho a experiência mais provavelmente do que se poderia esperar dos sonhos utópicos impregnados do conteúdo corpóreo do mundo tal qual é.

Nada é mais distante dos acontecimentos reais que o sistema racional fechado. Em determinadas circunstâncias, nada contém um impulso mais irracional do que uma visão de mundo intelectualista e totalmente auto-suficiente. Não obstante, existe em qualquer sistema racional formal o perigo de que o elemento extático quiliástico venha a refluir por trás de uma fachada intelectual. Portanto, nem toda utopia racional equivale à fé quiliástica, e nem toda utopia racional representa, neste sentido, um distanciamento e uma alienação do mundo. A natureza abstrata da utopia racional contradiz o intenso impulso emocional de uma fé quiliástica sensorialmente alerta ao presente completo e imediato. Assim, a mentalidade utópica racional, apesar de muitas vezes nascida da mentalidade quiliástica, pode inadvertidamente se tornar a sua primeira antagonista, da mesma forma que a utopia liberal-humanitária tendeu progressivamente a se voltar contra o quiliasma.

\section{b) A Segunda Forma da Mentalidade Utópia: A Ideia Liberal-Humanitaria}

Também a utopia do humanitarismo liberal surgiu do conflito com a ordem existente. Em sua forma característica, estabelece

23 Cf, Freyer, H., "Das Problem der Utopie”, Deutsche Rundschau, 1928, vol. 183, págs. 321-845. Também o livro de Girsberger, citado em detalhes adiante. 
igualmente uma concepção racional "correta" a ser utilizada contra a realidade maligna. Entretanto, não se utiliza esta contraconcepção como um plano de acordo com o qual se venha, em qualquer ponto do tempo, a reconstruir o mundo. Antes, serve meramente como uma "unidade de aferição", por meio da qual o curso dos acontecimentos concretos pode ser teoricamente avaliado. A utopia da mentalidade liberal-humanitária é a "ideia". Esta não consiste, entretanto, na ideia platônica estática da tradição grega, que era um arquétipo concreto, um modelo primeiro das coisas; aqui se concebe a ideia como um objetivo formal projetado no futuro infinito, cuja função consiste em proceder como um mero dispositivo regulador dos negócios mundanos.

Algumas outras distinções precisam, entretanto ser feitas. Onde, como por exemplo na França, a situação resultou em um ataque político, a utopia intelectualista assumiu uma forma racional com contornos decisivamente nítidos. ${ }^{24}$ Onde não foi possível seguir o mesmo caminho, como na Alemanha, a utopia se introverteu, assumindo uma tonalidade subjetiva. Aqui não se buscou o caminho do progresso pelas revoluções ou por feitos externos, mas exclusivamente pela constituição interna do homem e suas transformações.

A mentalidade quiliástica suprime todas as relações com as fases de existência histórica que se encontrem, em nosso meio, em um processo diário de vir a ser. Tende cada momento a entrar em hostilidade com o mundo, sua cultura e todas as suas obras e

24 Sobre o conceito francês de "ideia”, lemos no Deutsches Worterbuch do Grimm: “... num período mais remoto, o uso francês do século XVII dava a essa palavra o sentido rarefeito de representação mental, pensamento, conceito de algo" (Littré, 2, 50), E neste sentido que encontramos a palavra "ideia", sob a decisiva influência francesa, entre os escritores alemães da primeira metade do século XVIII; durante algum tempo a palavra é inclusive escrita com o acento francês. 
realizações terrenas, encarando-os como nada mais do que, gratificações prematuras de um esforço mais fundamental que somente pode satisfazer-se adequadamente no Kairos. ${ }^{25}$ "A atitude fundamental do liberal se caracteriza por uma aceitação positiva da cultura e pela atribuição de uma tonalidade ética aos assuntos humanos. Encontra-se mais em seu elemento quando no papel de crítico do que no de destruidor criativo. Não rompeu seu contato com o presente-o aqui e agora. A volta de cada acontecimento existe uma atmosfera de ideias inspiradoras c objetivos espirituais a serem alcançados.

Para o Quiliasma o espírito consiste em uma força que se difunde e se exprime por nosso intermédio. Para o liberalismo humanitário consiste naquele "outro domínio", ${ }^{26}$ que, ao ser absorvido em nossa consciência moral, vem a nos inspirar. As ideias e não o puro êxtase orientaram a atividade da época imediatamente anterior e posterior à Revolução Francesa, que se dedicou a reconstrução do mundo. Esta ideia humanitária moderna se irradiou, do campo político, a todas as esferas da vida cultural, culminando finalmente, na Filosofia "idealista", numa tentativa de alcançar o mais elevado estágio atingível de autoconsciência. O mais fértil período da história da Filosofia moderna coincide com o nascimento e a expansão desta ideia moderna, e quando novamente esta particular tendência na Filosofia, adequada ao horizonte humanitário liberal, passa a ter limites mais estreitos na esfera política, começa a se desintegrar.

25 Na mitologia grega, Kairos é o Deus da Oportunidade --o gênio do momento decisivo. A noção cristianizada disto é dada na obra de PaulTillich, The Religious Situation, traduzida por H. R. Niebuhr, Nova York, 1932, págs. 138-9: “Kairos é o tempo realizado, $\mathrm{O}$ momento do tempo invadido pela eternidade. Mas Kairos não é a perfeição ou a realização no tempo". (Nota do tradutor da ed. inglêsa)

26 Cf- Freyer, Op. cit., pág. 323 
O destino da Filosofia idealista se achava muito estreitamente vinculado à posição social de seus protagonistas para que deixássemos de assinalar, pelo menos sob este aspecto, o mais importante estágio desta relação. No que concerne à sua função social, a Filosofia moderna emergiu para derrubar a visão de mundo clerical-teológica. Foi, antes de mais nada, adotada pelos dois partidos que na época se encontravam em ascensão -a monarquia absoluta e a burguesia, somente mais tarde se tornou exclusivamente a arma da burguesia, quando veio a representar a um só tempo a cultura e a política. A monarquia, ao se tornar reacionária, foi buscar refúgio nas ideias teocráticas. Também o proletariado veio a se emancipar do quadro intelectualista da Filosofia idealista, que havia anteriormente mantido em comum com a burguesia, agora seu adversário consciente.

O pensamento liberal moderno, que mantém um duplo conflito, é de uma textura peculiar, altamente elevada, uma criação da imaginação. Esta mentalidade idealista evita tanto a concepção visionária da realidade implicada no apelo quiliasta a Deus quanto a dominação conservadora e muitas vezes bitolada sobre as coisas e os homens, implicada na noção do mundo vinculada ao tempo e à terra. Socialmente, esta visão intelectualista encontra suas bases em um estrato médio, na burguesia e na classe intelectual. Esta visão, de acordo com a relação estrutural dos grupos que a representam, desenvolveu um curso médio entre a vitalidade, o êxtase e a índole vingativa dos estratos oprimidos, e a concretude imediatista de uma classe dominante feudal, cuias aspirações se achavam em total congruência com a realidade então existente.

O liberalismo burguês se encontrava por demais preocupado com as normas para se interessar pela situação efetiva, tal como esta existia na realidade. Daí ter necessariamente erigido para si seu próprio mundo ideal. Elevado e desvinculado, e ao mesmo tempo 
sublime, perdeu todo o sentido das coisas materiais, bem como qualquer relação real com a natureza. Neste contexto de sentido, a natureza, em grande parte, significava razoabilidade, um estado de coisas regulamentado pelos padrões eternos de certo e errado. Mesmo a arte da geração então dominante refletia as noções de sua Filosofia - o eterno, o incondicionado e um mundo destituído de corpo e individualização. ${ }^{27}$

Aqui, como na maioria dos demais períodos da história, a Arte, a Cultura e a Filosofia nada mais são do que a expressão da utopia central da época, configurada pelas forças sociais e políticas contemporâneas. Exatamente como a ausência de profundidade e de cor caracteriza a arte correspondente a esta teoria, uma ausência semelhante se torna aparente no conteúdo desta ideia liberal-humanitária. A ausência de cor corresponde à vacuidade de conteúdo em todos os ideais dominantes, no apogeu deste modo de pensamento: a cultura no sentido mais estreito, a liberdade, a personalidade constituem apenas arcabouços para um conteúdo que, se poderia dizer, tenha sido propositadamente deixado indeterminado. Já nas Cartas sobre a Humanidade de Herder, e, portanto, nos estágios iniciais do ideal de "humanidade", não há nenhum enunciado definido daquilo em que consiste o ideal: em um dado momento consiste na "razão e justiça", que aparecem como o objetivo; em outro consiste no "bem-estar do homem", que ele considera digno de nosso empenho.

A ênfase demasiada na forma em Filosofia, bem como em outros campos, corresponde a esta posição média e à falta de concretude de todas as suas ideias. A ausência de profundidade nas artes plásticas e a predominância do puramente linear correspondem à

27 Cf. pinder, das problem der Generation in der Kunstgeschichte Europas (Berlim,1926), págs, 67 e segs., 69. 
maneira de experimentar o tempo' histórico como um progresso e uma evolução unilineares. Esta concepção de progresso unilinear deriva, essencialmente, de duas fontes distintas.

Uma das fontes surgiu no desenvolvimento capitalista ocidental. O ideal burguês de razão, erigido como o objetivo, contrastava com o estado de coisas existente, sendo necessário preencher o hiato entre a imperfeição das coisas, tais como ocorriam em um estado de natureza, e os ditames da razão, por meio do conceito de progresso. Esta reconciliação das normas com o estado de coisas existente se efetuou através da crença de que a realidade se movesse continuamente para uma proximidade cada vez maior com o racional. Embora esta ideia da aproximação cada vez maior fosse inicialmente vaga e indeterminada, a ela é dada uma forma relativamente concreta e clássica pelo girondino Condorcet. Condorcet, como Cunow, ${ }^{28}$ teve a oportunidade de analisar corretamente sob o ponto de vista sociológico, incorporou a decepcionante experiência dos estratos médios após a queda dos girondinos ao conceito de história sustentado por estes estratos. Não se renunciava ao fim último de um estado de perfeição, mas se considerava a revolução apenas como um mero estágio de transição. A ideia de progresso colocava dificuldades em seu próprio caminho, ao descobrir os passos necessários e os estágios de transição implicados no processo de desenvolvimento, que, ainda se acreditava, fosse unilinear. Enquanto anteriormente tudo o que fosse provisório era afastado, do ponto de vista da razão, como erro ou preconceito, vamos encontrar em Condorcet pelo menos uma concessão de validade relativa aos estágios experimentais que precediam a um estado de perfeição. Os "preconceitos" prevalentes em qualquer época dada

28 Cunow, H., Die Marzsche Geschichts-, Gesellschaftsund Staatsthcoríe (Berlim, 1920), I, pág. 158. 
eram reconhecidos como inevitáveis. Foram assimilados à ideia de progresso como "partes do quadro histórico" do período, que, com o correr do tempo, veio-se diferenciando em estágios e períodos.

Outra fonte da ideia de progresso se encontra na Alemanha. $\mathrm{Na}$ Erziebung des Menscbengescblechts de Lessing, a ideia emergente de evolução possuía, segundo as opiniões de von der Goltz e Gerlich, ${ }^{29}$ um caráter Dietista secularizado. Se, em acréscimo a esta derivação, considerar-se que o pietismo, transplantado da Holanda para a Alemanha, continha originalmente certos elementos batistas, a ideia religiosa de desenvolvimento pode, nesse caso, ser entendida como um refluxo do impulso quiliástico como um processo em que a fé permanente ( Harren) se torna, no ambiente alemão, uma "espera e antecipação", vindo o sentido quiliástico de tempo se fundir imperceptivelmente a um sentido evolucionista.

Partindo de Arndt, Coccejus, Spener e Zinzendorf, a linha conduz a Bengal, o contemporâneo pietista de Lessing, que já falava da direção histórica de Deus e do progresso contínuo e uniforme desde o princípio até o fim do mundo. É dele que se pretende tenha Lessing recebido a ideia da infinita perfectibilidade da espécie humana, por ele então secularizada e combinada com a crença na razão, sendo assim legada, como uma herança, ao idealismo alemão.

Qualquer que seja a maneira pela qual esta concepção de progresso tenha surgido, seja como uma continuada transformação

29 Von der Goltz, "Die theologische Bedeutung ] A. Bengels und seiner Schüler", jahrbücher für deutsche Theologie (Gota, 1861), vol.VI, págs. 460-506. Gerlich, Fr., Der Kommumismus als Lehre vom tausendjährigen Reich (Munique, 1920). Este livro, escrito para fins propagandísticos, é em muitos aspectos simplificado e superficial, mas muitas ideias básicas, como as citadas acima, parecem estar muito bem compreendidas. ( Cf, o apêndice.) Doren (op. cit.) fez uma correta apreciação deste livro. 
da mentalidade religiosa, seja como um contramovimento por parte do racionalismo, nela já vinha contida, em contraste com a mentalidade quiliástica, uma crescente preocupação com o "aqui e agora" concreto do processo em curso.

O preenchimento das expectativas quiliásticas podia ocorrer a qualquer momento. Agora, com a ideia liberal-humanitária, o elemento utópico recebe uma localização definida no processo histórico - constitui o ponto culminante da evolução histórica. Em contraste com a concepção mais remota de utopia, que viria a irromper subitamente no mundo vinda totalmente do "exterior", esta noção significa, a longo prazo, uma atenuação relativa da noção de uma súbita mudança histórica. Desde então, mesmo uma visão utópica encara o mundo como se movendo na direção de uma realização de seus objetivos, ou de uma utopia. De outro ângulo, o utopismo se torna crescentemente vinculado ao processo de vir a ser. A ideia, que somente poderia ser completamente realizada em algum tempo distante, torna-se, no decurso do continuado desenvolvimento do presente, uma norma que, aplicada a detalhes, efetua uma gradativa melhoria. Quem quer que critique os detalhes se torna ligado por esta mesma crítica ao mundo como este se encontra. A participação nas mais imediatas tendências do desenvolvimento cultural do presente, a intensa fé no institucionalismo e no poder de formação da política e da economia caracterizam os herdeiros de uma tradição que não se encontram somente interessados em cultivar, mas que querem colher a safra desde agora.

Contudo, a política deste estrato social ascendente ainda não veio a captar efetivamente o verdadeiro problema da sociedade, e, nas épocas do antagonismo liberal contra o Estado, ainda não havia compreendido a importância histórica daquilo que os estratos dominantes dotavam de valor absoluto, ou seja, a importância do poder e da violência indisfarçada. Abstrata como possa parecer, 
quando vista segundo o ponto de vista dos conservadores, esta visão que repousa teoricamente sobre a cultura, no sentido mais estreito, e na Filosofia, e, praticamente, na Economia e na Política, não obstante ela é, na medida em que se refere a acontecimentos históricos terrenos, bastante mais concreta do que a mentalidade quiliástica com seu afastamento da história. Esta maior proximidade ao histórico transparece no fato de que o sentido histórico do tempo, sempre um sintoma seguro da estrutura de uma mentalidade, se encontra muito mais definido do que na mentalidade quiliástica. A mentalidade quiliástica não possuía, como vimos, sentido algum do processo de vir a ser; somente era sensível para o momento súbito, o presente impregnado de sentido. O tipo de mentalidade que permanece ao nível quiljástico tampouco sabe ou reconhece -mesmo quando seus opositores já tenham absorvido este ponto de vista ---o caminho que conduz a um objetivo ou um processo de desenvolvimento -conhece apenas o fluxo e o refluxo do tempo. Por exemplo, o anarquismo revolucionário, em que a mentalidade quiliástica se acha preservada em sua mais pura e autêntica forma, encara os tempos modernos, desde o declínio da Idade Média, como uma única revolução. "Faz parte do fato e do conceito de revolução que, à semelhança de uma febre de convalescença, ela venha entre dois acessos da enfermidade. Não existiria de todo se não fosse precedida pela fadiga nem seguida pela exaustão." ${ }^{30}$ Assim, muito embora esta atitude apreenda muito de seus opositores, algumas vezes assumindo um aspecto conservador e outras um aspecto socialista, ela surge, mesmo em nossos dias, nos instantes decisivos.

30 Landauer op. Cit., pág. 91. 
A experiência quiliástica absoluta do "agora", que exclui qualquer possibilidade de se experimentar o desenvolvimento, serve, entretanto, a única função de nos prover de uma diferenciação qualitativa do tempo. Existem, segundo esta visão, tempos impregnados de significado e tempos destituídos de significado. Reside neste fato uma importante abordagem a diferenciação históricofilosófica dos acontecimentos históricos. Sua significação somente poderá ser estimada após se haver tornado clara a impossibilidade de uma consideração empírica da história sem uma diferenciação histórico-filosófica do tempo (com frequência, latente e portanto imperceptível em seus efeitos). E, muito embora possa parecer improvável à primeira vista, a primeira tentativa, acima mencionada, de uma disposição qualitativa das épocas históricas surge realmente do distanciamento quiliástico e da experiência extática. A mentalidade normativo-liberal igualmente contem esta diferenciação qualitativa dos acontecimentos históricos manifestando, além do mais, um desprezo como a uma realidade maligna a tudo o que se tenha tornado uma parte do passado ou que seja parte do presente. Adia para o futuro remoto a realização efetiva destas normas, e, ao mesmo tempo, ao contrário do quiliasta, que antecipa sua realização em algum ponto extático além da história, vê esta realização como surgindo do processo de vir a ser do aqui e agora, a partir dos acontecimentos de nossa vida cotidiana. A partir disto se desenvolveu, como vimos, a concepção tipicamente linear de evolução e a conexão relativamente direta entre um objeto anteriormente transcendental e significativo e a existência presente efetiva.

A ideia liberal somente pode ser adequadamente entendida como uma contrapartida da atitude extática do quiliasta frequentemente oculta por trás de uma fachada racionalista e que oferece histórica e socialmente uma ameaça contínua e poderosa contra 
o liberalismo. Trata-se de um grito de guerra contra o estrato da sociedade cujo poder advém de sua posição herdada na ordem existente, estrato capaz de dominar o aqui e agora, a princípio inconscientemente e mais tarde através do cálculo racional.Vemos aqui a diversidade com que as utopias podem modelar toda a estrutura da própria consciência, e podem refletir a divergência entre dois mundos históricos e os dois estratos sociais correspondentes, fundamentalmente diferentes, e que corporificam dois horizontes.

O Quiliasma encontrou seu período de existência no mundo da idade Média em decadência, um período de tremenda desintegração. Tudo conflitava com tudo. Era o mundo de nobres, patrícios, aldeões, jornaleiros, vagabundos e mercenários, todos se guerreando mutuamente. Tratava-se de um mundo em sublevação e em inquietação, em que os mais profundos impulsos do espírito humano buscavam expressão externa. Neste conflito, as ideologias não se cristalizam de modo suficientemente claro, nem sempre sendo fissil determinar em definitivo a posição social a que cada uma delas pertencia. Como Engels observou claramente, foi a Revolta Camponesa que, pela primeira vez, reduziu a termos mais simples e $m$ os ambíguos o turbilhão espiritual e intelectual da Reformação. ${ }^{31}$ Torna-se agora mais claro que a experiência quiliastica é característica dos estratos mais baixos da sociedade. Subjacente a ela encontra-se uma estruturamental peculiar aos camponeses, aos jornaleiros, a um Lumpenproletariat incipiente, a pregadores fanaticamente emocionais, etc. ${ }^{32}$

31 Engels, der Deutsche bauernkrien, ed. Por merhring (berlin 1920). Págs. 40 e segs

32 Holl (op. cit., pág. 435) procura ver um argumento contra uma interpretação sociológica no fato de que as ideias de Münzer, as quais, de acordo com a tipologia geral de Max Weber (Wirtschaft und Gesellschaft; Grundriss der Sozialökonomik, Parte III, V, I, págs. 267 e segs., parág. 7), devem ser 
Longo tempo se passou até a aparição da forma seguinte de utopia. Entrementes, o mundo social havia sofrido uma completa transformação. "O cavaleiro se tornou um funcionário, o grande lavrador um cidadão obediente." (Freyer.) Tampouco a nova forma de utopia era a expressão do estrato mais baixo na ordem social; antes, era o estrato médio que se estava disciplinando através de auto-elaboração consciente e que considerava a ética e a cultura intelectual sua principal autojustificação (contra a nobreza), e que, inconscientemente, deslocou as bases da experiência do plano extático para um plano educacional.

Abstrata como possa parecer ao ponto de vista do quiliasta, ou à abordagem concreta dos conservadores, a ideia liberal, não obstante, deu vida a um dos mais importantes períodos da história moderna. Seu caráter abstrato, apenas gradualmente revelado pela crítica da esquerda e da direita, jamais foi sentido pelos expositores originais da ideia. Talvez residisse exatamente nesta indeterminação, que deixava em aberto uma gama de possibilidades e que estimulava a imaginação, aquela qualidade fresca e juvenil, aquela atmosfera estimulante e sugestiva que mesmo o Hegel envelhecido, apesar de sua reorientação para o conservadorismo, sentiu quando, nos últimos dias de vida, relembrava o penetrante impacto das grandes ideias do período revolucionário. Em contraste com as sombrias profundezas da agitação quiliástica, os elementos centrais

correlacionadas com as classes baixas, fossem também aceitas pelos "intelectuais" do período (como Seb. Franck, Karlstadt, Schwenkenfeld, etc.). Se alguém simplificar tanto o problema da Sociologia como ele o fez, é de esperar que se acabe por rejeitá-la. Max Weber sempre insistiu que sua tipologia geral foi criada para caracterizar tendências ideal-típicas, e não constelações únicas imediatamente perceptíveis (ibíd., pág. 10). A Sociologia que procura analisar históricamente constelações únicas deve proceder com cuidados especiais ao abordar a determinação sociológica da posição dos intelectuais 
da mentalidade intelectualista se achavam abertos à luz clara do dia. O ânimo dominante do Iluminismo, a esperança de que enfim as luzes raiariam sobre o mundo sobreviveu o bastante para dar a estas ideias, mesmo neste último estágio, seu poder de condução.

Entretanto, em acréscimo a esta promessa que estimulava a imaginação e mirava um horizonte distante, as mais profundas forças ofensivas das ideias do Iluminismo residem no fato de que apelavam à vontade livre e mantinham vivo o sentimento de ser indeterminado e incondicionado. $\mathrm{O}$ caráter distintivo da mentalidade conservadora consistia, entretanto, no fato de que cegava o fio desta experiência. E, se alguém deseja formular em uma só sentença a realização máxima do conservadorismo, poder-se-ia dizer que em consciente oposição à visão liberal, deu ênfase positiva à noção de determinação de nossas visões e de nosso comportamento.

\section{c) A Terceira Forma da Mentalidade Utópica: A Ideia Conservadora}

A mentalidade conservadora, como tal, não possui predisposição alguma a teorizar. $\mathrm{O}$ que se acha de acordo com o fato de que os seres humanos não teorizam sobre as condições concretas em que vivem enquanto a estas se encontram bem ajustados. Tendem, em tais condições de existência, a encarar 0 ambiente como fazendo parte de uma ordenação natural do mundo, que, em consequência, não apresenta problema algum. A mentalidade conservadora, como tal, não detém nenhuma utopia. Em termos ideais, acha-se por sua própria estrutura completamente em harmonia com a realidade sobre a qual, por hora, mantém domínio. Faltam-lhe todos os reflexos e aclaramentos do processo histórico que advenham de um impulso progressista. O tipo conservador de conhecimento consiste originalmente no gênero de conhecimento que fornece um controle prático. Compõe-se das 
orientações habituais e, frequentemente, também reflexivas, face aos fatores imanentes à situação. Existem elementos ideais em sobrevivência no presente como vestígios da tensão em períodos anteriores, quando o mundo ainda não se encontrava estabilizado e que, agora, somente atuam ideologicamente como fés, religiões e mitos, que se viram banidos para um mundo além da história. Neste estágio, o pensamento, como assinalamos, se inclina a aceitar o ambiente total na concretude acidental com que se dá, como se fosse a ordem adequada do mundo, a ser aceita de antemão e sem apresentar nenhum problema. Somente o contra-ataque de classes oponentes e a sua tendência a romper com os limites da ordem existente irá motivar a mentalidade conservadora para questionar as bases de seu domínio, ocasionando necessariamente, entre os conservadores, as reflexões histórico-filosóficas concernentes a eles mesmos. Surge, dessa forma, uma contra-utopia que serve como um meio de auto-orientação e de defesa.

Se as classes socialmente ascendentes não tivessem, na realidade, levantado estes problemas e se não lhes tivessem dado expressão em suas respectivas contra-ideologias, a tendência do conservadorismo a se tornar consciente de si teria permanecido latente, e o horizonte conservador teria permanecido em um nível de comportamento inconsciente. Mas o ataque ideológico de um grupo socialmente ascendente, representando uma nova época, ocasiona de fato uma certa consciência das atitudes e ideias que unicamente se afirmavam na vida e na ação. Evoluindo aguilhoada por teorias oponentes, a mentalidade conservadora somente descobre sua ideia ex post fato. ${ }^{33}$ Não é por acaso que, enquanto

33 Devemos considerar também a ideologia do absolutismo sob este aspecto, muito embora não possamos aborda-la em detalhes. Ela também mostra uma concepção originalmente voltada para o domínio de uma situação vital, e que adquire 
todos os grupos progressistas encaram a ideia anterior ao ato, para o conservador Hegel a ideia de uma realidade histórica somente se torna visível posteriormente, quando o mundo já tenha assumido uma forma interna fixa: "Apenas mais uma palavra concernente ao desejo de ensinar ao mundo o que deveria ser. Para tanto, a Filosofia, pelo menos, chega sempre demasiado tarde. A Filosofia, como o pensamento do mundo, não aparece até que a realidade tenha completado seu processo de formação e se tenha dado por acabada. A história, portanto, corrobora os ensinamentos da concepção de que somente na maturidade da realidade vem a aparecer o ideal como uma contra, partida do real, apreende o mundo real em sua substância e o conforme como um reino intelectual. Quando a Filosofia pinta seu cinza sobre cinza, uma forma de vida envelheceu, e por meio do cinza ela não pode ser rejuvenescida, mas somente conhecida.

O mocho de Minerva somente alça seu voo quando chega o crepúsculo." 34 $\mathrm{Na}$ mentalidade conservadora, o "mocho de Minerva" realmente só inicia seu voo com a escuridão que se aproxima.

a tendência a refletir friamente sobre a técnica de dominação da mesma forma que o chamado maquiavelismo, somente mais tarde (em grande parte compelida por seus adversários) aparece a necessidade de uma justificação mais intelectual e elaborada da ocupação do poder. Para a confirmação desta proposição mais geral, citamos a seguinte passagem de Meinecke que observa o processo referido:

"Assim surgiu o ideal do Estado moderno que aspira não apenas a ser um Estado político (Machtstaat), mas também um Estado cultural, e a raíson d'état quanto a meros problemas de manutenção imediata do poder, que ocupou largamente a atenção dos teóricos do século XVII, foi ultrapassada". Isto se refere particularmente à época de Frederico, o Grande. Meineeke, Fr., Die Idee der Staatsrãson in der neuefen Geschichte (Munique, Berlim, 1925), pág. 353.

34 Famoso parágrafo final do prefacio da Filosofia do direito, de Hegel. 
Em sua forma original, a mentalidade conservadora não se achava, como mencionamos, preocupada com ideias. Foi o seu opositor liberal quem, por assim dizer, veio a forçar sua entrada no campo de conflito. A particular característica do desenvolvimento intelectual parece residir exatamente no fato de que o mais recente antagonista é que dita o ritmo e a forma da luta. Seguramente pouca verdade existe na chamada ideia progressista de que somente o novo detém os horizontes da existência futura, enquanto tudo o mais gradativamente evanesce. Pelo contrário, deve o mais velho, guiado pelo mais novo, transformar-se continuamente, acomodando-se ao nível do mais recente opositor. Assim, em nossos dias, os que tenham utilizado modos de pensamento remotos, ao depararem com argumentos sociológicos, devem igualmente recorrer a estes mesmos métodos. Da mesma forma, no princípio do século XIX, o modo de pensamento intelectualista liberal levou os conservadores a se interpretarem por meios intelectualistas.

É interessante observar que as classes sociais originalmente conservadoras, que haviam anteriormente adquirido estabilidade pelo apego à terra (Möser, v. d. Marwitz) não conseguiram uma interpretação teórica de sua própria posição, e que a descoberta da ideia conservadora se tornou o trabalho de um corpo de ideólogos que se vincularam aos conservadores.

A realização nesta direção, dos românticos conservadores, e especialmente de Hegel, consistia em sua análise intelectual do significado da existência conservadora.Tendo aí um ponto de partida, forneceram uma interpretação intelectual de urna atitude face ao mundo que já se encontrava implícita na conduta efetiva, mas que não se havia ainda explicitado. Daí, no caso dos conservadores, o que corresponde à ideia é, em essência, algo bastante diferente da ideia liberal. Constituiu a grande realização de Hegel estabelecer, em oposição à ideia liberal, uma contrapartida conservadora, não 
no sentido de criar, por uma combinação artificial, uma atitude e um modo de comportamento, mas, antes, elevando um modo de experiência já existente a um nível intelectual e enfatizando as características distintivas que o destacassem da atitude liberal face ao mundo.

Os conservadores encaravam a ideia liberal que caracterizou o período do Iluminismo como algo fluido e carente de concretude. E foi deste ângulo que a atacaram, depreciando-a. Hegel a considerava nada mais do que uma mera "opinião" urna simples imagem uma possibilidade apenas por trás da qual as pessoas se refugiam, escapam, fugindo às demandas do momento.

Em oposição a esta mera "opinião", esta imagem puramente subjetiva, os conservadores conceberam a ideia como enraizada e se expressando concretamente na realidade viva do aqui e agora. Significado e realidade, norma e existência, não estão aqui separados, porque o utópico, a "ideia concretizada", acha-se, em um sentido vital, presente neste mundo. $O$ que no liberalismo não passa de uma norma formal adquire, no conservadorismo, um conteúdo concreto nas leis prevalentes do Estado. Nas objetivações da cultura, na arte e na ciência, a espiritualidade se desdobra, e a ideia se expressa em uma plenitude tangível.

Já tivemos ocasião de observar que, na utopia liberal, na ideia humanitária, em Oposição ao êxtase quiliástico, existe uma relativa aproximação ao "aqui e agora". Encontramos no conservadorismo completado o processo de aproximação ao "aqui e agora”. A utopia se encontra neste caso, desde os momentos iniciais, implantada na realidade existente.

A isto corresponde, evidentemente, o fato de que a realidade, o "aqui e agora", não venha mais a ser vivenciada como uma realidade "maligna", mas como a corporificação dos vais elevados valores e significados. 
Embora se verifique que a utopia, ou a ideia, tenha-se tornado completamente congruente com a realidade concretamente existente, isto é, tenha sido assimilada a esta, este modo de experiência pelo menos no mais elevado ponto do período criador desta corrente não conduz, todavia, a uma eliminação das tensões e a uma aceitação inerte e passiva da situação como esta se apresenta. Um certo grau de tensão entre a ideia e a existência surge do fato de que nem todo elemento desta existência encarna significação e de ser sempre necessário distinguir entre o que é essencial e o que é não-essencial, e, ainda, de que o presente nos defronta continuamente com tarefas e problemas novos que não tenham ainda sido dominados. No intuito de atingir alguma norma de orientação, não deveríamos confiar em impulsos subjetivos, mas recorrer às forças e ideias que em nós, ou em nosso passado, tenham adquirido objetivação; ao espírito que, até agora, tenha atuado dentro de nós para a criação daquelas, que são nossas obras. Mas esta ideia, este espírito, não foi racionalmente conclamado nem arbitrariamente escolhido o melhor dentre um número de possibilidades. Ou se acha em nós, como uma "força atuando silenciosamente" (Savigny), percebida subjetivamente, ou se trata de algo como uma enteléquia que se desdobra nas criações coletivas da comunidade, do povo, da nação ou do Estado, como uma forma interna a ser, em sua maior parte, morfologicamente percebida. A perspectiva morfológica, dirigida para a linguagem, para a arte e para o Estado se desenvolve a partir deste ponto. Praticamente no mesmo momento em que a ideia liberal colocou a ordem existente em movimento, estimulando a especulação construtiva, Goethe se voltou desta abordagem ativística para a contemplação para a morfologia. Dispôs-se a usar a apercepção intuitiva como um instrumento de ciência. A abordagem da escola histórica é em alguns aspectos análoga à de Goethe. Seguem a emanação de "ideias" através da Observação 
da linguagem, dos costumes, da lei, etc., fazendo uso não de generalizações abstratas, mas, antes, de intuição simpática e descrição morfológica.

Também neste caso, a ideia que assume uma posição central na experiência política (isto é, a forma de utopia correspondente a esta posição social) auxiliou na conformação do segmento da vida intelectual que se achava vinculado à política. Em todas as variações destas buscas pela "forma interna", persistia a mesma atitude conservadora de determinação e, quando se projetar exteriormente, irá igualmente encontrar expressão na ênfase sobre a determinação histórica. De acordo com esta noção, e segundo o ponto de vista desta atitude face ao mundo, o homem não e' de forma alguma absolutamente livre. Nem todas as coisas em geral, e cada coisa em particular, são possíveis a todo momento e em todas as comunidades históricas. A forma interna de individualidade histórica existente em qualquer época dada, seja a de uma personalidade isolada, seja a de um espírito de povo, e as condições externas que, juntamente com o passado, se encontram por trás dela, todas determinam a conformação das coisas por existir. É por esta razão que a configuração histórica existente em uma dada época não pode ser construída artificialmente, mas cresce como uma planta, a partir da semente. ${ }^{35}$

Mesmo a forma conservadora de utopia, a noção de uma ideia implantada e expressa na realidade, somente pode ser entendida,

35 A constituição dos Estados não pode ser inventada, os mais esclarecidos cálculos nesta matéria são tão ineficazes como a total ignorância. Não há substitutivo para o espirito do povo, para a força e ordem que dele dimanam, que não podem ser encontrados mesmo nas mentes mais brilhantes dos grandes gênios". (Muller, Adam, Uber Konig Friedrich II und die natur, Wuder, und Bestimmung der preussischen monarchie (berlin, 1810), pág.49). Esta ideia, derivada do romatismo, tornou-se o tema central de toda a tradição conservadora. 
em última análise, à luz de seus conflitos com as demais formas coexistentes de utopia. Seu antagonista imediato é a ideia liberal, que foi traduzida em termos racionalistas. Enquanto nesta última acentua-se a experiência do normativo, o "deveria", no conservadorismo a ênfase se desloca para a realidade existente, o "é". O fato da mera existência de uma coisa dota-a de um valor mais elevado, seja isto devido, como no caso de Hegel, ao teor de racionalidade mais elevado por ela encarnado, ou, como no caso de Stahl, devido aos efeitos fascinantes e mistificadores exatamente de sua irracionalidade. "Existe algo de maravilhoso em experimentar aquilo de que se pode dizer que é este é o teu pai, este é o teu amigo, e, através deles, atingistes esta posição.' "Por que exatamente a esta?' 'Por que és exatamente a pessoa que és? Esta incompreensibilidade consiste no fato de que a existência jamais pode ser plenamente absorvida no pensamento, e de que a existência não é uma necessidade lógica, mas tem suas bases em um poder autônomo mais elevado. ${ }^{36}$ Aqui, o fecundo antagonismo entre, de um lado, a ideia encarnada e expressa na realidade e, do outro, a que meramente existe (derivada dos dias sossegados do conservadorismo) ameaça transformar-se em uma congruência total, tendendo o quietismo conservador a justificar, por meios irracionais, simplesmente tudo o que exista.

O sentido de tempo deste modo de experiência e de pensamento se opõe completamente ao do liberalismo. Enquanto, para o liberalismo, o futuro constituía tudo e o passado nada, o modo conservador de experimentar o tempo encontrou a melhor corroboração de seu sentido de determinação ao descobrir a importância do passado, na descoberta do tempo como um criador

36 Stahl, Fr. J,. Die Philosophie des Rechts, 14, pág. 272. 
de valor. A duração absolutamente não existia para a mentalidade quiliástica, ${ }^{37}$ somente existindo para o liberalismo na medida em que, desde então, possibilita o progresso. Contudo, para o conservadorismo, tudo o que existe possui um valor positivo e nominal, simplesmente porque veio lenta e gradativamente e existir. Em consequência, não só se volta a atenção para o passado, fazendo-se um esforço para salvá-lo do esquecimento, como também a presença e a imediação de todo o passado se torna uma experiência concreta. Nesta visão, não se pode mais pensar a história como uma mera extensão unilinear de tempo, nem tampouco ela consiste em simplesmente unir a linha que, do presente, conduz ao futuro, àquela que, do passado, conduziu ao presente. A concepção de tempo ora em questão possui uma imaginária terceira dimensão que deriva do fato de o passado ser experimentado como virtualmente presente. "A vida do espírito contemporâneo constitui um ciclo de estágios, que, por um lado, ainda contém uma coexistência sincrônica, e somente por outro prisma aparece como uma sequência no tempo já passado. As experiências que o espírito parece ter atrás de si existem igualmente nas profundidades de seu ser presente." (Hegel)..$^{38}$

37 Munzer diz, além disso: "Os intelectuais e eruditos nao sabem por que as Santas Escrituras devem ser aceitas ou rejeitadas, mas somente que vêm sendo transmitidas desde um passado remoto... os judeus, os turcos e todos os outros povos têm também tal forma simiesca, imitativa, de justificar suas crenças”. (Holl, pág. 432, nota 2-)

38 Hegel, Vorlesungen über die Philosophie der Geschichte (Leipzig, Reclam, 1907), cf. págs, 123-5. Maiores referências poderão ser encontradas em minha obra Das konservative Denken, págs. 98 e segs., onde tentei, pela primeira vez, compreender as formas de "sentido histórico do tempo" à luz da estrutura da consciência política dada, em determinado momento. Para outras referências, cf. o seguinte: Stahl procura caracterizar o sentimento de tempo e da Vida de Schelling, Goethe e Savigny com as seguintes palavras: "nestes escritores acontece o mesmo que em todas as fases e nuanças da vida: parece que o que é, 
A experiência quilizística localiza-se fora do domínio do tempo, mas, nas ocasiões em que irrompeu no domínio temporal, santificava o momento incidental.A experiência liberal estabeleceu uma conexão entre a existência e a utopia, ao reportar ao futuro a ideia, enquanto objetivo pleno de significado e permitindo, através do progresso, que as promessas da utopia venham, pelo menos em alguns aspectos, gradativamente a ser realizadas em nosso próprio meio. A experiência conservadora se funde ao espírito que, em um dado momento, surgiu sobre nós vindo de fora, e ao qual damos expressão, com o que já existe, permitindo que se tornasse objetivo, se expandisse em todas as dimensões, dotando, assim, cada acontecimento de um valor intrínseco e imanente.

O modo conservador de experiência, afora seu conflito com a ideia liberal, teve que manter seu combate particular com a concepção quiliástica, a que sempre encarara como um inimigo interno.A mesma experiência quiliástica, que começou na época dos anabatistas a desempenhar um papel ativo no mundo, tinha outro destino a esperá-la, algo diverso dos até agora mencionados.Vimos já três tendências alternativas na experiência quilizística. Ou bem permanece inalterada, persistindo em sua forma emergente original, frequentemente vinculada a ideologias as mais fundamentalmente divergentes --como, por exemplo, no anarquismo extremista ou reflui, desaparecendo, ou, ainda, se "sublima" em uma ideia. Segue outro caminho, distanciando-se dos acima mencionados, quando mantém sua tendência supratemporal e extática introvertendo-se, e, neste caso, não mais ousando aventurar-se no mundo, perdendo

sempre foi assim. Mas quando olhamos para trás, descobrimos o que mudou. Mas não é tão óbvio para nós descobrir onde e como a transição de um estágio a outro ocorreu. No curso do mesmo desenvolvimento invisível, as situações e circunstâncias próximas emergem e mudam 
seu contato com os eventos mundanos. Impelido por circunstâncias externas, o modo quiliástico-extático de experiência seguiu na Alemanha, em uma extensão bastante ampla, este caminho de introversão. As subcorrentes pietistas, que podem ser acompanhadas durante longos períodos nos países germânicos, representam esta introversão do que fora o êxtase quiliástico.

Mesmo quando introvertida, a experiência extática representa um perigo para a ordem existente, pois se acha constantemente tentada a se expressar exteriormente, e somente a prolongada disciplina e a repressão transformam-na em quietismo. A ortodoxia, por isso, manteve um combate constante contra o pietismo, somente entrando em uma união aberta com este quando a ofensiva revolucionária necessitou da conclamação de todas as forças disponíveis para a espiritualização dos poderes dominantes. Sob pressões externas e devido às situações estruturais sociologicamente inteligíveis, a experiência quiliástica, através justamente desta introversão, naturalmente sofre uma mudança de caráter. Neste, como em outros casos, a interpenetração estrutural dos fatores socialmente "internos" e dos fatores "externos" pode ser acompanhada em detalhe. Enquanto originalmente a experiência quiliástiea manifestava um impulso corpóreo e robusto, ao se ver reprimida tornou-se, pelo contrário, docemente inócua e fluida, liquefez-se em mero entusiasmo, somente vindo o elemento extático a reviver novamente, embora de uma forma suavemente mitigada, na "experiência do despertar" pietista.

O que, entretanto, é mais importante para as conexões que desejamos assinalar é que, através da perda de contato com o mundo no processo efetivo de vir a ser (este contato, observado segundo o ponto de vista do conjunto, ocorre na esfera política e não na esfera privada), esta atitude desenvolve uma incerteza interna. Surge no lugar do tom pontificante da profecia quiliástica 
a vacilação insegura, a indecisão pietista frente à ação. Somente se poderá entender adequadamente a "escola histórica" na Alemanha, com seu quietismo e sua ausência de padrões, quando se tiver levado em conta sua continuidade com o pietismo.Tudo o que uma pessoa ativa expressa espontaneamente, sendo desde logo aceito, se acha aqui destacado de seu contexto erigido em problema. A "decisão" se torna uma fase independente de ação, sobrecarregada de problemas, e esta separação conceitual entre o ato e a decisão unicamente aumenta a incerteza, ao invés de elimina-la. O esclarecimento interno propiciado pelo pietismo não oferece solução alguma para a maioria dos problemas da vida cotidiana, e se, de súbito, se tornar necessário atuar no processo histórico, procura-se interpretar os acontecimentos da história como se fossem indicações da vontade de Deus. Neste momento, instala-se o movimento das interpretações religiosas da história, ${ }^{39}$ através do qual se esperava eliminar a indecisão interna na atividade política. Mas, ao invés de encontrar uma solução para os problemas da conduta correta e ao invés de a história fornecer orientação divina, esta incerteza interna foi projetada no mundo.

É importante para o modo de experiência conservadora, ativo, subjugar igualmente esta forma de utopia e harmonizar a seu próprio espírito as energias vitais latentes aí presentes. O que se precisa aqui controlar é o conceito de "liberdade interna", que ameaça constantemente transformar se em anarquismo (já que uma vez se transformou em uma revolta contra a Igreja). Também aqui a ideia conservadora, implantada na realidade, desenvolve uma influência repressiva sobre a utopia esposada pelos inimigos internos. De acordo com a teoria dominante do conservadorismo, a "liberdade

39 Alguns dos aspectos mais importantes desta tendência foram bem estudados por meu aluno Requadt, P., v. muller und der fruhhistorismus (Munique, 1929). 
interna", em seu objetivo temporal indefinido, deve subordinar-se ao código moral, código este ia definido. Ao invés de "liberdade interna", temos "liberdade objetiva", a que a primeira deve ajustarse. Isto poderia ser interpretado em termos metafísicos como uma harmonia preestabilizada entre a liberdade internamente subjetivizada e a liberdade externamente objetivizada. Que esta corrente do movimento, caracterizada por atitudes pietistas introspectivas, se conforme a interpretação acima, somente se explica por sua fatal impotência frente aos problemas do mundo. Desta forma, passa as rédeas ao domínio do grupo conservador realista quer sujeitandose inteiramente, quer retirando-se para algum canto obscuro. Mesmo hoje em dia encontra-se grupos arquiconservadores que nada querem ouvir sobre política de força da época de Bismarck e que, na orientação de introversão da corrente que se erigiu em oposição a Bismarck, veem os elementos verdadeiramente valiosos da tradição. ${ }^{40}$

\section{d) A Quarta Forma da Mentalidade Utópica: A Utopia Socialista-Comunista}

Mesmo o modo de pensamento e de experiência socialistacomunista que, no concernente a suas origens, pode ser tratado como uma unidade, será melhor entendido em sua estrutura utópica se for observado por três ângulos.

O socialismo precisou, por um lado, radicalizar a utopia liberal, a ideia, e, por outro, precisou tornar impotente ou, em um dado caso, superar completamente a oposição interna do anarquismo em

40 Cf. Deuthscher Staat und Deutsche Parteien: in Festschrift, Fr. Meineck Zum 60. Geburtstag dargebracht (Munique, Berkin, 1922)., por exemplo, a última seção de ensaio de v. martin, "Weltanschauliche Motive im altkonsertiven Denken", 
sua forma mais extrema. Seu antagonista conservador é considerado apenas secundariamente, assim como na Vida política geralmente se procede mais firmemente contra o opositor proximamente relacionado do que contra o distante, porque é maior a tendência a resvalar para o seu ponto de vista, sendo consequentemente necessário se exercer uma vigilância especial contra esta tentação interna. O comunismo, por exemplo, luta com maior energia contra o revisionismo do que o faz contra o conservadorismo. Isto nos auxilia a compreender por que a teoria socialista-comunista ostenta uma disposição a aprender muito com o conservadorismo.

O elemento utópico do socialismo, devido a esta situação multifacetada e à sua tardia origem, apresenta uma face de Jano. Representa não apenas um compromisso, mas também uma nova criação, baseada em uma síntese interna das Várias formas de utopia até então surgidas e que se vêm combatendo mutuamente na sociedade.

O socialismo concorda com a utopia liberal no sentido de que ambos acreditam que o domínio da liberdade e da igualdade somente virá a existir no futuro remoto. ${ }^{41}$ É, contudo, característico que o socialismo localize este futuro em um ponto muito mais especificamente determinado, que é o período da derrocada da cultura capitalista. Esta solidariedade do socialismo com a ideia

41 Esta asserção não se aplica ao socialismo antes do século XIX. O socialismo utópico do Iluminismo do século XVIII, num período em que os fisiocratas interpretavam a história à luz da ideia de progresso, tinha sua utopia localizada no passado, correspondendo à mentalidade pequeno-burguesa reacionária de seus defensores. Sociològicamente, essa volta ao passado tem suas raíazes, em parte, na persistência de certos remanescentes do antigo sistema de terra "comum", que de algum modo mantinha viva a memória das instituições "comunistas" do passado. Quanto a esta relação, muitos detalhes podem ser encontrados em Girbeger, H., Der utopische sozialismus des. 1. Jahrhunderts in Frankreich und seine philosophiaschen und materiellen Grunndlagen: Zurcher Volkswirtschaftliche Forschungen, Heft I, cf. esp. Págs. 94 e segs. 
liberal, em sua orientação para um objetivo localizado no futuro, encontra explicação em sua comum oposição à aceitação e afirmação conservadoristas diretas e imediatas da ordem existente. A ampla indefinição e espiritualidade do objetivo distante corresponde, igualmente, à rejeição liberal e socialista da excitação quiliástica e ao seu comum reconhecimento de que as energias extáticas latentes devam ser sublimadas através de ideais culturais.

Contudo, na medida em que a questão seja a da penetração da ideia no processo de evolução e no desenvolvimento gradativo dela, a mentalidade socialista não a experimenta nesta forma espiritualmente sublimada. Defrontamo-nos aqui com a ideia sob a forma de uma nova substância, quase à semelhança de um organismo vivo que tenha condições definidas de existência, cujo conhecimento pode tornar-se o objeto de investigação científica. Neste contexto, as ideias não são sonhos nem desejos, imperativos imaginários baixados de alguma esfera absoluta; antes, possuem uma vida concreta própria e uma função definida no processo total. Arrefecem quando se tornam antiquadas e podem ser realizadas quando o processo social atinge uma dada situação estrutural. Destituídas desta relevância para a realidade, tornam se meras "ideologias" obscurizantes.

Ao se analisar a posição liberal, descobre-se, de uma perspectiva bastante diversa da empregada pelo conservador, o caráter abstrato e puramente formal de sua ideia. A "mera opinião", a mera imagem da ideia que somente se realiza na atitude subjetiva, é também aqui reconhecida como inadequada, estando sujeita à crítica sob outro ângulo, que não o da oposição conservadora. Não basta ter boas intenções em abstrato e postular no futuro remoto um domínio realizado de liberdade, cujos elementos não se acham sujeitos a controle. Seria antes necessário tomar consciência das condições reais (neste caso econômicas e sociais) sob as quais está 
realização de desejos possa tomar-se de alguma forma operante. $\mathrm{O}$ caminho que, do presente, conduz a este objetivo distante deve ser igualmente investigado, de modo a serem identificadas as forças do processo contemporâneo, cujo caráter dinâmico e imanente, sob nossa direção, conduza passo a passo à realização da ideia. Enquanto o conservadorismo depreciava a ideia liberal como uma mera opinião, o socialismo, em sua análise da ideologia, elaborou um método crítico coerente, que, na verdade, constituía uma tentativa de anular a utopia dos antagonistas, ao demonstrar que tinham suas raízes na situação existente.

Desde então, vem ocorrendo um conflito desesperado visando a desintegração fundamental das crenças do adversário. Cada uma das formas de mentalidade utópica até o momento tratadas por nós, voltando-se contra as demais, exige que correspondam à realidade, e, em cada caso, apresenta ao adversário, como "realidade" uma forma de existência diversamente constituída. A estrutura econômica e social da sociedade torna-se para o socialista a realidade absoluta. Transforma-se na portadora da totalidade cultural que os conservadores já haviam percebido como uma unidade. A concepção conservadora de espírito de povo (Volksgeist) foi a primeira tentativa relevante de compreender os fatos aparentemente isolados da vida intelectual e psíquica, como emanações de um único centro de energia criadora.

Para os liberais, tanto quanto para os conservadores, esta força propulsora constituía algo de espiritual. Na mentalidade socialista, pelo contrário, emerge, da secular afinidade dos estratos oprimidos por uma orientação materialista, uma glorificação dos aspectos materiais da existência, anteriormente experimentados apenas como fatores negativos e obstrutivos.

Mesmo na valoração ontológica dos fatores que constituem o mundo sempre o mais característico de qualquer estrutura de 
consciência uma hierarquia de valores, inversa à empregada por outros modos de pensamento, vai aos poucos atingindo predomínio. As condições "materiais", anteriormente encaradas tão-só como obstáculos malignos no caminho da ideia, são aqui hipostasiadas em força motora dos assuntos do mundo, sob a forma de um determinismo econômico reinterpretado em termos materialistas.

A utopia que alcança a mais próxima relação com a situação histórica e social deste mundo evidencia esta aproximação não apenas ao localizar seu objetivo cada vez mais no interior do quadro da história, mas ao elevar e espiritualizar a estrutura econômica e social imediatamente acessível. O que acontece aqui é, essencialmente, uma particular assimilação do sentido conservador de determinismo à utopia progressista que busca refazer o mundo. O conservador, devido a sua consciência de ser determinado, glorificava o passado, a despeito ou mesmo devido à sua função determinante e, ao mesmo tempo, dava, de uma vez por todas, uma indicação adequada da importância do passado para o desenvolvimento histórico. Entretanto, para os socialistas, é a estrutura social que se torna a força mais influente no momento histórico, encarando-se seus poderes conformadores (em uma forma glorificada) como os fatores determinantes de todo o desenvolvimento.

O fenômeno novo que aqui encontramos, o sentimento de determinismo, é perfeitamente compatível, entretanto, com uma utopia localizada no futuro. Enquanto a mentalidade conservadora estabelecia naturalmente a conexão do sentimento de determinação com a afirmação do presente, o socialismo combina uma forca social progressista com as restrições que a ação revolucionária automaticamente se impõe ao perceber as forças determinantes da história. 
Estes dois fatores, a princípio imediatamente interligados, divergem no decorrer do tempo para formar duas facções oponentes, mas em interação mútua no movimento socialista-comunista. Os grupos que chegaram recentemente ao poder e que, ao participar e ao partilhar da responsabilidade pela ordem existente, se comprometam com as coisas como são, exercem uma influência de retardamento, ao esposarem a mudança através de uma evolução ordenada. Por outro lado, os estratos que ainda não possuíam nenhum interesse investido nas coisas tais quais são tornaram-se os portadores daquela teoria comunista (e também da sindicalista) que enfatiza a suprema importância da revolução.

No entanto, antes da cisão, que corresponde a um posterior estágio no processo, esta mentalidade progressista tinha antes de mais nada de se estabelecer face à oposição dos demais partidos. Dois obstáculos tinham que ser ultrapassados: o sentido de indeterminação histórica contido no quiliasma, que assumiu uma forma moderna no anarquismo radical, e esta mesma cegueira quanto às forças determinantes da história que acompanha o sentido de indeterminação da "ideia" liberal.

$\mathrm{Na}$ história da moderna experiência quiliástica foi decisivo ${ }^{42}$ o conflito entre Marx e Bakunin. Foi no desenrolar deste conflito que veio a ter fim o utopismo quiliástico.

Quanto mais um grupo que se prepara para assumir o poder busca tornar-se um partido, tanto menos irá tolerar um

42 Sobre Bakunin, ver as obras de Nettlau, Ricarda Huch e Fr. Brupbacher. A obra deste último, Marx und Bakunin (Berlim-Wilmerdorf, 1922), oferece uma exposição concisa de muitos problemas importantes. As obras completas de bakunin foram editadas na Alemanha por "Der Syndikalist". Cf. também a confissão de Bakunin ao Czar Nicolau I, descobertas nos arquivos secretos do chefe da terceira seção da Chancelaria do último Czar, e traduzida por K. Kersten, Berlim, 1926. 
movimento que, de uma forma sectária e irruptiva, visa, em algum momento indeterminado, a tomar de assalto as fortalezas da história.Também aqui, a desaparição de uma atitude fundamental pelo menos sob a forma de que falávamos se acha intimamente ligada à desintegração da realidade econômica e social que constitui seu embasamento (como Brupbacher teve ocasião de demonstrar). ${ }^{43} \mathrm{~A}$ vanguarda de Bakunin, os anarquistas da Federação de Jura, desintegrou-se quando o sistema doméstico de manufatura relojoeira, em que se achavam aplicados e que lhes possibilitava uma atitude sectária, foi superada pelo sistema industrial de produção. No lugar de uma experiência oscilante e não-organizada da utopia extática, surge o bem organizado movimento revolucionário marxista. Podemos novamente notar aqui que a maneira de o grupo conceber o tempo manifesta mais claramente o tipo de utopia em consonância com o qual a consciência do grupo se organiza. Aqui se experimenta o tempo como uma série de pontos estratégicos.

Esta desintegração da utopia extática anarquista foi brusca e brutal, tendo sido contudo ditada, como fatal, uma necessidade pelo próprio processo histórico. Uma visão de apaixonada profundidade desapareceu do primeiro plano da cena política e o sentido de determinismo veio a se impor sobre uma esfera mais ampla.

O pensamento liberal se relaciona ao pensamento anarquista porque também possuía um sentido de indeterminismo, muito embora (como já foi visto) chegasse, através da ideia de progresso, a uma relativa proximidade com o processo histórico concreto. $\mathrm{O}$ sentido liberal de indeterminismo se baseava na fé em um relacionamento imediato com uma esfera absoluta de imperativos éticos

43 Brupbacher, op. Cit., págs. 60 e segs., 204 e segs. 
à própria ideia. Esta esfera de imperativos éticos não derivava sua validade da história; não obstante, para o liberal, a ideia podia, nela, tornar-se uma força impulsora. Não é que o processo histórico produza as ideias, mas somente a descoberta das ideias, sua expansão e o "esclarecimento" a seu respeito é que as torna forças históricas. Uma verdadeira revolução copernicana ocorreu quando o homem começou a considerar não apenas a si próprio, não só o homem, mas também a existência, a validade e a influência destas ideias como fatores condicionados, encarando o desenvolvimento das ideias como vinculado à existência e integrante do processo histórico-social. O que antes de mais nada importava ao socialismo não era combater esta mentalidade absolutista entre seus opositores, mas, antes, estabelecer, em seu próprio campo, a nova atitude em oposição ao idealismo ainda dominante. Bem cedo, portanto, ocorreu este afastamento das utopias da "alta burguesia", cuia melhor análise pode ainda ser encontrada em Engels.

Saint-Simon, Fourier e Owen ainda sonhavam suas utopias no estilo intelectualista antigo, embora já trouxessem a marca de ideias socialistas. A situação deles à margem da sociedade se exprimia em descobertas que alargavam as perspectivas sociais e econômicas; entretanto, retinham em seu método o aspecto de indeterminação característico do Iluminismo. "Para todos eles, o socialismo e' a expressão da verdade, da razão e da justiça absolutas, precisando apenas ser descoberto para conquistar o mundo através de seu próprio poder." ${ }^{44}$ Também aqui, tinha que se vencer uma ideia e, em consequência, o sentido de determinação histórica deslocou a outra forma competidora de utopia. A mentalidade socialista, em um sentido bem mais fundamental do que a ideia liberal, representa

44 Engels, F., Die entwicklung des sozialismus von der utopie zur Wissenschaft, 4 . $^{\circ}$ ed.., Berlim 1894 
uma redefinição da utopia em termos de realidade. Será somente ao término do processo que a ideia se estabelece em sua indefinição e indeterminação proféticas, mas o caminho que, das coisas tais são, conduz à realização da ideia já se encontra claramente demarcado histórica e socialmente.

Aqui, novamente, existe uma diferença na maneira de se experimentar o tempo histórico: enquanto o liberal concebia o tempo futuro como sendo uma linha reta conduzindo diretamente a um objetivo, surge agora uma distinção entre o próximo e o remoto, uma distinção cujos primórdios já se encontravam em Condorcet e que é de importância tanto para o pensamento quanto para a ação. O conservadorismo já diferenciava o passado desta maneira, mas desde que sua utopia ia tendendo cada vez mais para uma completa harmonia com o estágio de realidade já atingido na época, o futuro permanecia, para o conservador, completamente indiferenciado. Somente através da união de um sentido de determinação com uma concepção viva do futuro, seria possível criar um sentido histórico de tempo com mais de uma dimensão. Mas esta perspectiva mais complexa de tempo histórico, que o conservadorismo já havia criado para o passado, possui, aqui, uma estrutura completamente diferente.

Não é somente através da Virtual presença de cada acontecimento passado que cada experiência presente encarna uma terceira dimensão apontando de volta ao passado, mas igualmente porque o futuro está sendo nela preparado. Não é apenas o passado, mas igualmente o futuro, que tem uma existência virtual no presente. Uma ponderação de cada um dos fatores existentes no presente e uma intuição das tendências latentes nestas forças somente podem 
ser obtidas se se compreender o presente à luz de sua concreta realização no futuro. ${ }^{45}$

Enquanto a concepção liberal do futuro era inteiramente formal, estamos aqui lidando com um processo de concretização gradativa. Embora esta conclusão do presente pelo futuro seja, de início, imposta pela vontade e por imagens desiderativas, este esforço orientado para um objetivo atua como um fator heuristicamente seletivo, tanto na pesquisa quanto na ação. De acordo com este ponto de vista, o futuro está continuamente se testando no presente. Ao mesmo tempo, a ideia, que a princípio era apenas uma vaga profecia, está sendo constantemente corrigida e tornada mais concreta à medida que o presente se adianta para o futuro. A "ideia" socialista, em sua interação com os acontecimentos "reais", opera não como um princípio transcendente e puramente formal, que do exterior regula o acontecimento, mas, antes, como uma "tendência" no interior da matriz desta realidade, continuamente se corrigindo com referência a este contexto. A investigação concreta da interdependência de toda a gama de acontecimentos, dos econômicos aos psíquicos e aos intelectuais, deve reunir as observações isoladas em uma unidade funcional, contra o embasamento de um todo em desenvolvimento.

45 Uma confirmação da análise acima e uma quase matematicamente exata confirmação de nossa teoria sobre os modos diferenciais, social e politicamente, de experimentar o tempo histórico, é dada pelo seguinte excerto de um artigo de comunista J. Révai: “O presente só existe realmente em virtude da existência do passado e do futuro - o prsente é a forma do passado desnecessário e do futuro irreal. A tática é o futuro manifestando-se como presente". ("Das Problem der Taktik”, em Kommunismus: Zeitchrift der kommunistischen Internationale, 1920, II, pág. 1676. A presença virtual do futuro no presente é aí claramente expressada. Está em completo contrate com a citação de Hegel, anteriormente feita.) Devese-ia comparar esta frase com outras citações dispersas no presente texto. 
Dessa forma, nossa visão da história vai adquirindo um quadro de referência cada vez mais concreto, diferenciado, mas ao mesmo tempo mais flexível. Examinamos cada acontecimento com vista a descobrir o que significa e qual a sua posição na estrutura total em desenvolvimento.

Seguramente, a área de livre escolha se torna, assim, mais restrita; descobre-se um número maior de determinantes, pois não só o passado constitui um fator de determinação, mas a situação econômica e social do presente também condiciona o acontecimento possível. O propósito orientador não consiste mais, aqui, em uma atividade com base em impulsos fortuitos em direção a algum aqui e agora arbitrariamente escolhido, mas, antes, em fixar a atenção sobre um ponto de ataque favorável no todo estrutural ci em que vivemos. Torna-se tarefa do líder político reforçar deliberadamente as forças cuja dinâmica pareça adiantar-se na direção por ele desejada, e orientar em sua própria direção, ou pelo menos tornar impotentes as que pareçam opor-se a ele. A experiência histórica se torna, dessa forma, um verdadeiro plano estratégico. Tudo o que existe na história pode ser agora experimentado como um fenômeno intelectual e volitivamente controlável.

Também neste caso, o ponto de vista inicialmente formulado na área política penetra toda a vida cultural: da investigação sobre a determinação social da história surge a Sociologia que, por seu turno, se transforma gradativamente em uma ciência-chave cuja perspectiva permeia todas as Ciências Históricas especiais que tenham alcançado um estado similar de desenvolvimento. Uma confiança e uma segurança, autorizadas pelo sentimento de determinação, fazem surgir ao mesmo tempo um ceticismo criador e um élan disciplinado. Um tipo especial de "realismo" permeia o domínio da arte. O idealismo do filisteu burguês de meados do século XIX dissipou-se e, enquanto persistir uma tensão fecunda 
entre o ideal e a existência, os valores transcendentes, concebidos a partir de agora como encarnados na existência efetiva, serão buscados no próximo e no imediato.

\section{A utopia na situação contemporânea}

No momento atual o problema assumiu sua forma própria e singular. O próprio processo histórico nos mostra uma utopia que, em uma dada época, transcendia completamente a história, vir gradativamente descendo em uma aproximação cada vez mais chegada à vida real. Ao se tornar mais próxima da realidade histórica, sua forma sofre mudanças tanto em função quanto em substância. $\mathrm{O}$ que de origem se colocava em absoluta oposição à realidade histórica tende agora, seguindo o modelo do conservantismo, a perder seu caráter de oposição. Claro está que nenhuma das formas destas forças dinâmicas que emergem em uma sequência histórica jamais desaparece por completo, e tampouco em época alguma qualquer delas é incontestavelmente dominante. A coexistência destas forças, sua oposição recíproca, bem como sua constante interpenetração mútua, dão existência a formas cuja riqueza de experiência histórica aparece pela primeira vez.

A fim de não obscurecer com um excesso de detalhes o que é decisivo, somente ressaltamos as mais importantes tendências em toda esta variedade, emprestando-lhes uma ênfase maior ao retratá-las como tipos ideais. Muito embora, no decorrer da história, jamais se perca realmente nada desta multiplicidade de coisas e de acontecimentos, é possível mostrar com crescente clareza diversos graus de predomínio e de alinhamento das forças em atuação na sociedade. Ideias, formas de pensamento e energias psíquicas persistem e são transformadas em estreita conexão com as forças 
sociais. Nunca é por acaso que elas aparecem em determinados momentos do processo social.

A este propósito, está à vista um determinante estrutural específico que, pelo menos, merece indicação. Quanto maior a classe que adquire um certo domínio sobre as condições concretas de existência, e tanto maiores as possibilidades de uma vitória por meio de uma evolução pacífica, tanto mais tenderá esta classe a seguir o caminho do conservadorismo. Isso significa, porém, que os diversos movimentos terão renunciado aos elementos utópicos em seus modos de vida.

Isso se demonstra de uma maneira mais nítida pelo fato, já mencionado, de que a forma relativamente mais pura da mentalidade quiliástica moderna, tal como se acha encarnada no anarquismo radical, desaparece quase que por completo da cena política, resultando daí que se elimina um elemento de tensão das formas remanescentes de utopia política.

É verdade, certamente, que muitos dos elementos que constituíam a atitude quiliástica foram transmutados e se refugiaram no sindicalismo e no bolchevismo, sendo assimilados e incorporados à atividade destes movimentos. Dessa forma, transfere-se para eles, e particularmente para o bolchevismo, a função de acelerar e de catalisar a ação revolucionária, ao invés de deificà-la.

O abrandamento generalizado da intensidade utópica se verifica ainda noutro sentido importante: cada utopia que se fórum em um estágio posterior de desenvolvimento, manifesta uma aproximação maior ao processo histórico-social. Quanto a este aspecto, a ideia liberal, a socialista e a conservadora nada mais são do que estágios diversos e, na verdade, formas de oposição no processo que vai continuamente se distanciando do quiliasma e se aproximando cada vez mais dos acontecimentos deste mundo. 
Todas estas formas de oposição à utopia quiliástica evoluem em íntima conexão com o destino dos estratos sociais que as adotaram originalmente. Como tínhamos visto, constituem formas já moderadas do êxtase quiliástico original, mas no decurso de um desenvolvimento posterior eliminam estes derradeiros vestígios utópicos, aproximando-se involuntariamente da atitude conservadora.Ao que tudo indica, constitui lei geralmente válida da estrutura do desenvolvimento intelectual o fato de que, na ocasião em que novos grupos penetram em uma situação já estabelecida, eles não adotem de imediato as ideologias já elaboradas, mas, antes, adaptem as suas ideias tradicionais à nova situação. Assim, o liberalismo e o socialismo, ao entrarem em uma situação mais conducente ao conservadorismo, adotaram intermitentemente as ideias que o conservadorismo thes oferecia como modelo, preferindo, entretanto, em geral adaptar à nova situação as suas ideologias originais. Quando estes estratos vieram a ocupar a posição social previamente mantida pelos conservadores, desenvolveram espontaneamente um sentimento de vida e modos de pensamento que se encontravam estruturalmente relacionados ao conservadorismo. A intuição inicial do conservador quanto à estrutura do determinismo histórico, a ênfase e, sempre que possível, a super ênfase das forças em silenciosa atuação, a contínua absorção do elemento utópico na vida cotidiana apareceram também no pensamento destes estratos, às vezes sob a forma de uma nova criação espontânea, outras como uma reinterpretação de antigos padrões conservadores.

Verificamos portanto que, condicionado pelo processo social, se desenvolve nestes tipos de pensamento, em diversos pontos e sob diversas formas, um relativo afastamento em relação a utopia. Este processo, que por si só já possui uma qualidade dinâmica própria, é acelerado ainda mais em seu ritmo e intensidade pelo fato de que diferentes formas coexistentes de mentalidade utópica se estejam 
destruindo em um conflito recíproco. Tal conflito recíproco entre as diversas formas de utopia não acarreta necessariamente o aniquilamento do próprio utopismo, pois o conflito, por si mesmo, não faz senão elevar a intensidade utópica. A forma moderna de conflito recíproco apresenta, todavia, uma peculiaridade já que a destruição do adversário não se verifica a um nível utópico, fato que se torna mais nitidamente perceptível no modo pelo qual os socialistas empreenderam o desmascaramento das ideologias de seus antagonistas. ${ }^{46 " ~ N a ̃ o ~ a c u s a m o s ~ o ~ a d v e r s a ́ r i o ~ d e ~ a d o r a r ~ f a l s o s ~}$ deuses; destruímos a intensidade de sua ideia demonstrando que ela é histórica e socialmente determinada.

O pensamento socialista, que até aqui vem desmascarando as utopias de todos os seus adversários como ideologias, jamais levantou o problema da determinação com respeito à sua própria posição, jamais aplicou o método a si mesmo e nunca tefreou seu próprio desejo de ser absoluto. No entanto, é inevitável que também aqui o elemento utópico desapareça, com o aumento do sentido de determinação. Aproximamo-nos, assim, de uma situação em que o elemento utópico, através de suas muitas formas divergentes, ter-se-á (pelo menos na política) aniquilado completamente. Ao se tentar seguir as tendências que já se dão, projetando-as no futuro, a profecia de Gottfried Keller "O triunfo final da liberdade será estéril" ${ }^{47}$ passa a assumir, pelo menos para nós, um alarmante significado.

Sintomas desta "esterilidade" se revelam em muitos fenômenos contemporâneos, podendo ser claramente entendidos como radiações da situação política e social nas esferas mais remotas da

46 A mudança de significado do conceito de ideologia, que apresentamos na parte II, é simplesmente uma frase deste processo mais geral.

47 . "Der freiheir letzter sieg widr trocken sein" 
vida cultural. Com efeito, quanto mais ativamente um partido em ascensão colabora em uma coalizão parlamentar, tanto mais abandona seus impulsos utópicos originais e, com eles, sua perspectiva ampla, tanto mais seu poder para transformar a sociedade tenderá a ser absorvido por seu interesse em detalhes isolados e concretos. Em termos bastante paralelos à mudança que pode ser observada no domínio político, efetua-se uma mudança na visão científica que se conforma às demandas políticas: o que constituíra meramente um esquema formal e uma visão total e abstrata tende a se dissolver em uma investigação de problemas específicos e distintos. O esforço utópico visando a um objetivo e a possibilidade, intimamente relacionada a ele, de uma perspectiva ampla desintegram-se, no conselho consultivo parlamentar e no movimento sindical, em mero conjunto de orientações para dominar um vasto número de detalhes concretos, com vista a assumir posição política quanto a eles. Da mesma forma, no campo da pesquisa, o que anteriormente constituía uma Weltanschauung unificada e sistematizada converte-se, no intento de lidar com problemas individuais, em uma mera perspectiva orientadora e em um princípio heurístico. Mas desde que todas as formas mutuamente conflitantes de utopia atravessam o mesmo ciclo de vida, tornam-se, tanto no domínio da ciência quanto no da prática parlamentar, cada vez menos artigos de fé mutuamente conflitantes, e cada vez mais partidos em competição ou possíveis hipóteses de pesquisa. Enquanto em uma época de ideais liberais a Filosofia refletia melhor a situação social e intelectual, hoje em dia a condição interna das situações intelectuais e sociais se reflete mais claramente nas diversas formas de Sociologia.

A visão sociológica das classes que ascendem ao poder sofre transformações segundo linhas particulares. Estas teorias sociológicas, à semelhança de nossa atual concepção cotidiana do mundo, 
encarna os "pontos de vista possíveis" conflitantes que nada mais são do que transformações gradativas de utopias anteriores. $\mathrm{O}$ que esta situação tem de peculiar é que, nesta luta competitiva pela correta perspectiva social, todas estas abordagens e pontos de vista conflitantes de forma alguma se "desacreditam" a si próprios, isto é, não se revelam fúteis ou incorretos. Antes, demonstram com uma clareza crescente ser possível pensar proveitosamente, de qualquer ponto de vista, embora o grau de proveito a ser atingido varie de posição a posição. Cada um destes pontos de vista revela, de um ângulo diverso, as inter-relações no complexo total de acontecimentos, crescendo dessa forma a suspeita de que o processo histórico seja algo mais abrangente que todos os pontos de vista individuais existentes, e de que nossa base de pensamento não alcance, no presente estado de atomização, uma visão compreensiva dos acontecimentos. A massa de fatos e de pontos-de-vista é muito maior do que o atual estado de nosso aparato teórico e de nossa capacidade de sistematização pode comportar.

Isto, porém, lança uma nova luz sobre a necessidade de nos acharmos continuamente preparados para uma síntese, em um mundo que vai atingindo um dos altos pontos de sua existência. $\mathrm{O}$ que anteriormente se desenvolvem aleatoriamente, a partir das particulares necessidades intelectuais de classes e círculos sociais restritos se toma de súbito perceptível como um todo, e a profusão de acontecimentos e de ideias produz um quadro bastante confuso.

Não é por fraqueza que um povo, chegado a um estágio maduro de desenvolvimento histórico e social, se submete às diferentes possibilidades de visualizar o mundo, tentando encontrar um quadro teórico que as abranja todas. Essa submissão surge antes da intuição de que cada uma das certezas intelectuais antecedentes repousava sobre pontos de vista parciais tornados absolutos. 
Constitui uma característica de nossos dias o fato de que os limites destes pontos-de-vista parciais se tenham revelado evidentes.

Neste estágio maduro e adiantado de desenvolvimento, a perspectiva total tende a desaparecer em proporção ao desaparecimento da utopia. Somente os grupos da extrema esquerda e da extrema direita, na vida moderna, acreditam haver uma unidade no processo de desenvolvimento. No primeiro encontramos o neomarxismo de um Lukacs, com a sua obra de profunda importância, e no último o universalismo de um Spann. Seria supérfluo demonstrar, a esta altura, as diferenças nos pontos-de-vista sociológicos destes dois extremos, reportando-nos as diferenças em suas concepções da totalidade. Não estamos interessados em esgotar essa questão, mas, antes, em uma determinação provisória dos fenômenos sintomáticos da situação atual.

Diferentemente dos autores acima mencionados, que encaram a categoria de totalidade como uma entidade metafísico-ontologia, Troeltsch a utilizou como uma hipótese de trabalho na pesquisa. Empregou-a em uma forma um tanto experimental, como um princípio ordenador para uma abordagem da massa de dados e, recorrendo a diferentes linhas de tratamento do material, buscou descobrir os elementos que em qualquer época lhe conferissem uma unidade. Alfred Weber procura reconstruir o todo de uma época histórica passada como uma Gestalt -uma unidade configurativa por meio da qual se pode observar intuitivamente. Seu método se coloca em decidida oposição ao dogmatismo racionalista fundado sobre a dedução. O fato de que Troeltsch e Alfred Weber, como democratas, se encontrem entre os dois extremos de Lukács e de Spam se reflete em suas respectivas estruturas mentais. Embora aceitem a concepção de totalidade, o primeiro evita qualquer pressuposto metafisico: ontológico ao falar dela, e o último 
rejeita a atitude racionalista geralmente associada a essa concepção pelos radicais.

Em contraste com os adeptos do marxismo ou com a tradição histórico-conservadora em sua concepção da totalidade, outro elemento do grupo intermediário procura ignorar inteiramente o problema da totalidade a fim de, com base nesta renúncia, ser capaz de concentrar mais plenamente sua atenção na abundância de problemas particulares. Toda vez que a utopia desaparece, a história deixa de ser um processo que conduz a um fim último. $\mathrm{O}$ quadro de referência de acordo com o qual avaliamos os fatos deixa de existir, restando-nos uma série de acontecimentos, todos idênticos no que se refere à sua significação interna. Desaparece o conceito de tempo histórico, que conduzia a épocas qualitativamente diferentes, e a história se torna cada vez mais semelhante ao espaço não-diferenciado. Todos os elementos de pensamento enraizados nas utopias são agora vistos de um ponto de vista cético e relativista. Ao invés da concepção de progresso e da dialética, adotamos a busca de tipos e de generalizações válidas eternamente, e a realidade se torna apenas uma combinação especial destes fatores gerais (cf. a Sociologia Geral de Max Weber).

O quadro conceitual da Filosofia Social que fundamentava os trabalhos dos últimos séculos parece desaparecer com a fé nas utopias como alvos coletivos dos esforços humanos. Esta atitude cética, fecunda em muitos sentidos, corresponde primariamente à posição social de uma burguesia já no poder, cujo futuro se converteu gradativamente em seu presente. Os demais estratos da sociedade manifestam tendências idênticas, à medida que também se aproximam da realização de seus objetivos. Não obstante, a evolução concreta de seu modo de pensamento atual também se acha até certo ponto sociologicamente determinada pela situação histórica em que tiveram origem. Caso se retire do método sociológico 
marxista a concepção dinâmica de tempo, também aqui teremos uma teoria generalizante da ideologia que, sendo cega às diferenciações históricas, iria vincular as ideias exclusivamente às posições sociais dos que as mantêm, sem considerar a sociedade em que ocorrem nem a função particular que ali possam exercer.

Os contornos de uma Sociologia indiferente à noção histórica de tempo já eram perceptíveis na América, onde o tipo dominante de mentalidade tornou-se mais completo e rapidamente congruente com a realidade da sociedade capitalista do que ocorreu no pensamento alemão. Na América, a Sociologia derivada da Filosofia da História foi bem mais cedo posta de lado. A Sociologia, ao invés de constituir um retrato adequado da estrutura do conjunto da sociedade, esfacelou-se em uma série de problemas técnicos distintos de reajustamento social.

"Realismo" tem diferentes significações em contextos diferentes. Na Europa, significava que a Sociologia tinha de focar sua atenção na tensão bastante acentuada entre as classes, enquanto na América, onde havia maior liberdade de ação no campo econômico, não era tanto o problema das classes que se considerava o centro "real" da sociedade, mas os problemas de técnica e de organização sociais. Para as formas de pensamento europeu que se encontravam em oposição ao status quo, Sociologia significava a solução do problema das relações de classe --de um modo mais geral, um diagnóstico científico da época atual. Para o americano, pelo contrário, significava a solução dos problemas técnicos e imediatos da vida social. Isto ajuda a explicar por que, na formulação eu ropéia de problemas sociológicos, sempre se faz a desconcertante pergunta sobre o que nos guarda o futuro e, de maneira semelhante, se lança a luz sobre o impulso, estreitamente correlato, para uma perspectiva total. Do mesmo modo é possível explicar, com base nesta diferença, o tipo de pensamento envolvido 
na formulação americana do problema, representado da seguinte forma: Como é que faço isso? Como é que resolvo este problema concreto isolado? E em todas estas indagações sentimos o eco otimista: não preciso preocupar-me com o todo, o todo toma conta de si próprio.

$\mathrm{Na}$ Europa, contudo, o desaparecimento completo de todas as doutrinas que transcendem a realidade as utópicas bem como as ideológicas -ocorreu não apenas pelo fato de se mostrar que todas estas noções eram relativas à situação econômico-social, mas também por outros meios. A esfera da realidade última repousava na esfera econômica e social, pois era a esta que o marxismo vinculava, em última análise, todas as ideias e valores; estava ainda histórica e intelectualmente diferenciada, isto é, ainda continha algum fragmento da perspectiva histórica (devido amplamente a sua derivação hegeliana). O materialismo histórico era materialista apenas no nome; a esfera econômica em, em última análise, apesar de ocasionais negativas deste fato, um inter-relacionamento estrutural de atitudes mentais. $\mathrm{O}$ sistema econômico existente era exatamente um "sistema", isto é, algo que se forma na esfera do espírito (o espírito objetivo, como o entendia Hegel). O processo que de início começou por solapar a validade dos elementos espirituais na história passou, mais tarde, a perturbar esta esfera do espírito, reduzindo todos os acontecimentos a funções de impulsos humanos, completamente desligados dos elementos históricos e espirituais. Isto também possibilitou uma teoria generalizante; os elementos que transcendem à realidade, as ideologias, as utopias, etc. Já não se achavam em relação com situações sociais de grupo, mas com impulsos -com formas eternas da estrutura dos impulsos humanos (Pareto, Freud, etc.). Esta teoria generalizar-te dos impulsos já fora prenunciada na Filosofia Social e na Psicologia Social 
inglêsas dos séculos XVII e XVIII. Assim, por exemplo, em seu Enquiry concerning Human Understanding, dizia Hume:

"Reconhece-se universalmente que haja uma grande uniformidade entre as ações dos homens, em todas as nações e em todas as épocas, e que a natureza humana permaneça sempre a mesma, em seus princípios e manifestações. Os mesmos motivos produzem sempre as mesmas ações. Os mesmos acontecimentos decorrem sempre das mesmas causas. A ambição, a avareza, o egoísmo, a vaidade, a amizade, a generosidade, o espírito público: estas paixões, combinadas em vários graus e distribuídas pela sociedade, têm sido desde o início do mundo, e ainda o são, a fonte de todas as ações e iniciativas que se têm sempre observado na humanidade." 48

Este processo de completa destruição de todos os elementos espirituais, os utópicos bem como os ideológicos, encontra um paralelo nas mais recentes tendências da vida moderna, e nas tendências correspondentes no domínio da arte. Não devemos encarar o desaparecimento na arte do humanitarismo, a emergência de uma "constatação de fato" (Sachlichkeit) na vida sexual, na arte e na arquitetura e a expressão dos impulsos naturais no esporte -não se deveria interpretar tudo isso como sintomático do crescente recesso dos elementos utópicos e ideológicos da mentalidade dos estratos que virão a dominar a situação atual? Não deveriam a gradativa redução da Política à Economia, em cuja direção existe pelo menos uma tendência perceptível, a rejeição consciente do passado e da noção de tempo histórico, o abandono consciente de qualquer "ideal cultural", ser interpretados como um desaparecimento, também na arena política, de qualquer forma de utopismo?

48 Hume, Enquiries concerning the Human Understanding and concerning the Principles of Morals. Ed. por L. A. Selby-Bigge, 2. ${ }^{a}$ ed. (Oxford, 1927), pág. 83. 
Aqui, uma certa tendência para agir sobre o mundo promove uma atitude para a qual todas as ideias se acham desacreditadas e todas as utopias, destruídas. Esta atitude prosaica que vem surgindo atualmente deve ser em grande parte bem recebida como o único instrumento de domínio sobre a situação atual, como a transformação do utopismo em ciência e como a destruição das ideologias enganadoras que se acham em incongruência com a realidade de nossa presente situação. Seria necessário ou bem uma insensibilidade que nossa geração provavelmente já não poderia adquirir ou, então, a crédula ingenuidade de uma geração recentemente nascida para o mundo, para se poder viver em inteira congruência com as realidades deste mundo, totalmente despidas de qualquer elemento transcendente, quer sob a forma de uma utopia, quer sob a de uma ideologia.

Em nosso atual estágio de autoconsciência, esta seria talvez a única forma de existência real possível em um mundo que já não se acha em formação. É possivel que o melhor que nossos princípios éticos têm a oferecer seja a "autenticidade" e a "franqueza", no lugar dos antigos ideais. A "autenticidade" (Echtbeikstegorie) e a franqueza aparentam não ser mais do que a projeção da "constatação de fato" ou do "realismo" gerais de nossos dias, no campo da Ética. Talvez um mundo que não esteja mais em formação possa permitir-se isso. Mas acaso teremos atingido um estágio em que possamos dispensar o esforço? Não iria esta eliminação de todas as tensões Significar igualmente a eliminação da atividade política, do cuidado científico numa palavra, do próprio conteúdo da vida?

Assim, se não nos quisermos contentar com esta "constatação de fato", devemos levar avante nossa pesquisa e indagar se não existiriam outras forças em atividade no campo social, além dos estratos sociais que, pela sua atitude satisfeita, promovem este relaxamento da tensão psicológica. Caso a pergunta seia colocada desta maneira, contudo, a resposta deverá ser a seguinte:A aparente 
ausência de tensão no mundo de hoje está sendo solapada por dois lados. De um lado, acham-se os estratos cujas aspirações ainda não se realizaram e que se inclinam para o comunismo e para o socialismo. Para eles, a unidade da utopia, do ponto de vista e da ação é inconteste enquanto permaneçam a margem do mundo atual. A sua presença na sociedade implica a ininterrupta existência de, pelo menos, uma forma de utopia, e, assim, até certo ponto, sempre fará que tornem a se acender e a se conflagrar contra-utopias, pelo menos todas as vezes que esta ala de extrema esquerda entre em ação. Se isto ira ou não de fato acontecer, depende amplamente da forma estrutural do processo de desenvolvimento com que atualmente nos defrontemos. Se formos capazes de, através de uma evolução pacifica, alcançar, em um estágio posterior, uma forma algo superior de industrialismo que seja suficientemente elástica e que proporcione aos estratos mais baixos um grau de relativo bem-estar, então também elas sofrerão o tipo de transformação que já se evidenciou nas classes detentoras do poder. (Deste ponto de vista, pouco importa que esta forma superior de organização social do industrialismo, através do acesso dos estratos mais baixos a uma posição de poder, redunde em um capitalismo suficientemente elástico para assegurar-lhes um relativo lativo bem-estar, ou que este capitalismo seja antes transformado em comunismo.) Se este estágio posterior do desenvolvimento industrial somente puder ser obtido através da revolução, os elementos utópicos e ideológicos do pensamento voltarão a florescer, com renovado vigor, por toda parte. Seja como for, será no poder social desta ala da oposição à ordem existente que se irá encontrar um dos determinantes de que depende o destino dos conceitos que transcendem a realidade.

Mas a forma futura da mentalidade utópica e da intelectualidade não depende apenas das vicissitudes deste estrato social 
extremo. Em acréscimo a este fator sociológico, ainda existe outro a ser considerado neste sentido: um estrato médio social e intelectual distinto que, apesar de manter uma relação definida com a atividade intelectual, não foi considerado em nossa análise anterior. Até agora todas as classes abrangeram, além dos que efetivamente representavam seus interesses diretos, Outro estrato mais orientado para o que se pode chamar de reino do espírito. Sociologicamente, poderiam ser denominados "intelectuais", mas, para nossas finalidades, precisamos ser mais precisos. Não nos referimos aqui aos que portam as insígnias exteriores da instrução, mas aos poucos dentre estes que, consciente ou inconscientemente, se acham interessados em algo mais do que o sucesso no esquema de competição que visa a desalojar o atual. Por maior que seja a serenidade com que se encare a questão, não se poderá negar que este pequeno grupo quase sempre existiu. Sua posição não apresentava nenhum problema enquanto seus interesses intelectuais e espirituais estivessem em congruência com os da classe em luta pela supremacia social. Experimentava e conhecia o mundo segundo a mesma perspectiva utópica do grupo ou estrato social com cujos interesses se identificava. Isto se aplica tanto a Thomas Munzer quanto aos combatentes burgueses da Revolução Francesa, tanto a Hegel quanto a Karl Marx.

A situação deles se torna, no entanto, questionável sempre que o grupo a que se identificam alcança uma posição de poder, quando, em decorrência desta obtenção de poder, a utopia se desliga da política. Consequentemente, o estrato que era identificado com tal grupo, com base nesta utopia, é igualmente desligado.

Os intelectuais serão também desligados destes vínculos sociais tão logo o estrato mais oprimido da sociedade venha a partilhar do domínio da ordem social. Os intelectuais socialmente desvinculados serão, ainda mais do que hoje em dia, recrutados em 
proporções crescentes dentre todos os estratos sociais e não simplesmente dentre os mais privilegiados. Éste setor intelectual, que se vem tornando cada vez mais separado do resto da sociedade e se vê entregue a seus próprios recursos, defronta-se, sob outro aspecto, com o que acabamos de caracterizar como uma situação total que tende para o completo desaparecimento de tensão social. Mas uma vez que os intelectuais não se encontram de forma alguma em concordância com a situação existente, e que ela não deixa de lhes aparecer como problema, também eles se esforçam por ultrapassar esta situação desprovida de tensão.

As seguintes quatro alternativas se apresentam aos intelectuais que dessa forma se viram rejeitados pelo processo social: o primeiro grupo de intelectuais que se filiam à ala radical do proletariado socialista-comunista em absoluto nos interessa aqui. Para ele, pelo menos sob este aspecto, não existem problemas; o conflito entre a lealdade social e a intelectual ainda não existe.

O segundo grupo, que se viu rejeitado pelo processo social ao mesmo tempo que sua utopia era afastada, torna-se cético e passa em nome da integridade intelectual, a destruir os elementos ideológicos da ciência pela maneira acima descrita (Max Weber Pareto).

O terceiro grupo se refugia no passado e tenta encontrar ai uma época ou uma sociedade em que uma forma extinta de transcendência à realidade dominasse o mundo, e, através desta reconstrução romântica, tenta espiritualizar o presente. A mesma função, deste ponto de vista, e' desempenhada pelas tentativas de reanimar o sentimento religioso, o idealismo, os símbolos e os mitos.

O quarto grupo se isola do mundo e renuncia conscientemente a participação direta no processo histórico. Tomam-se extzíticos como os quiliastas, mas com a diferença de que já não 
se preocupam com movimentos políticos radicais. Tomam parte no grande processo histórico do desengano, em que todo significado concreto das coisas, bem como os mitos e as crenças vão sendo lentamente postos de lado. Diferem, entretanto, dos românticos, que visam essencialmente a conservar as crenças antigas em uma época moderna. Este êxtase a-histórico que inspirou tanto o místico quanto o quiliasta, se bem que de maneiras diferentes, se encontra agora colocado, em toda a sua crueza, no próprio centro da experiência. Vamos encontrar um sintoma deste fato, por exemplo, na arte moderna expressionista, em que os objetos perderam seu significado original, parecendo servir simplesmente como um meio para a comunicação do extático. De modo semelhante, no campo da Filosofia, vários pensadores não-acadêmicos, como Kierkegaard, rejeitaram, na busca de fé, todos os elementos históricos concretos da religião, e tendem, em última análise, para uma pura e extática "existência em si". Tal afastamento do elemento quiliástico do meio da cultura e da política talvez preservasse a pureza do espírito extático, mas deixaria o mundo sem significação nem vida. Este afastamento acabará sendo fatal também ao êxtase quiliástico, desde que, como já vimos, ao se interiorizar e abandonar seu conflito com o mundo concreto imediato, ele tende a se tornar manso e inócuo, ou a se perder em um pura auto-edificação.

Terminada esta análise, é inevitável que nos indagassem o que o futuro nos guarda; e a dificuldade desta questão põe a nu a estrutura da compreensão histórica. Predizer é tarefa de profetas, e cada profecia transforma necessariamente a história em um sistema puramente determinado, privando-nos, dessa forma, da possibilidade da escolha e decisão. Como um resultado posterior, desfaz-se o impulso a pesar e a refletir com relação a esta esfera constantemente emergente de novas possibilidades. 
A única forma em que o futuro se nos apresenta é a da possibilidade, ao passo que o imperativo, o "deveria", nos diz qual destas possibilidades devemos escolher. No que se refere ao conhecimento, o futuro - enquanto não estamos interessados na parte puramente organizada e racionalizada -se apresenta como um meio impenetrável, um muro intransponível. E, quando nossas tentativas de devassã-los são repelidas, começamos a tomar consciência da necessidade de escolher resolutamente o nosso caminho, e, em estreita conexão, da necessidade de um imperativo (uma utopia) que nos leve avante. Somente quando sabemos quais os interesses e imperativos envolvidos, é que estamos em posição de questionar as possibilidades da situação presente e. assim, de obter nosso primeiro "insight" da história. Aqui, finalmente, vemos por que só pode existir uma interpretação da história na medida em que está se oriente pelo interesse e pelo esforço intencional. Das duas tendências em conflito no mundo moderno -as correntes utópicas em luta contra uma tendência complacente a aceitar o presente -é dificil dizer de antemão qual acabará por vencer, pois o curso da realidade histórica que determinará esta vitória repousa ainda no futuro. Poderíamos mudar toda a sociedade amanhã, caso todos concordassem. O verdadeiro obstáculo e' que cada indivíduo se acha preso a um sistema de relações estabelecidas que, em grande parte, entrava a sua vontade. ${ }^{49}$ Mas estas "relações estabelecidas"

49 Aqui, também, em questões tão decisivas quanto estas, são reveladas as diferenças mais fundamentais nos modos de experimentar a realidade. $\mathrm{O}$ anarquista Landauer pode ser citado, representando um extremo: "O que entendeis então pelos fatos duros e Objetivos da história humana? Não, certamente, o solo, as casas, as máquinas, as estradas de ferro, as linhas telegráficas e coisas semelhantes. Se, porém, vos referia assim à tradição, ao costume e ao complexo de relações, objetos de pia reverência, tais como o Estado e organizações, condições e situações similares, então não é possível desfazermo-nos deles, dizendo que são simples aparências. A possibilidade e a necessidade do processo social, tal como da 
repousam, em última análise, sobre decisões não-controladas dos indivíduos. A tarefa consiste, portanto, em remover esta fonte de dificuldade, revelando os motivos ocultos subjacentes às decisões do indivíduo, e dessa forma colocando-o

Tudo o que foi dito até aqui, neste livro, destina-se a auxiliar o indivíduo a penetrar nestes motivos ocultos e a revelar as implicações de sua escolha. Entretanto, para o nosso propósito analítico mais restrito, que podemos designar como uma história sociológica dos modos de pensamento, torna-se claro que as mudanças mais importantes da estrutura intelectual da época de que nos ocupamos devem ser compreendidas à luz das transformações do elemento utópico. É possível, portanto, que no futuro, em um mundo em que nunca haja nada de novo, em que tudo esteja terminado, sendo cada momento uma repetição do passado, venha a existir uma condição em que o pensamento seja completamente

estabilidade à decadência, e dai para a reconstrução, baseia-se no fato de que não há organismo desenvolvido que esteja acima do indivíduo, mas uma complexa relação de razão, amor e autoridade. Assim, sempre novamente, ocorrem, na história de uma estrutura social, que é uma estrutura tão-só enquanto os indivíduos a alimentam com sua vitalidade, ocasiões em que os vivos se envergonham dela, como um fantasma estranho do passado, e criam novos agrupamentos. Por isso afastei meu amor, razão, obediência e vontade daquilo que chamo “Estado”, Que eu seja capaz de fazer isso depende da minha vontade. O não serdes capazes de fazer isto não altem o fato decisivo de que esta incapacidade particular está inseparávelmente ligada com vossa própria personalidade e não com a natureza do Estado." (De uma carta de Gustav Landauer a Margarete Susmann, transcrita em Landauer, G., sein Lebensgang in Briefen, ed. por Martin Buber (1929), vol. II, pág. 122.) No outro extremo, eis a seguinte citação de Hegel: "Visto que as fases do sistema ético são a concepção da liberdade, elas são a substância da essência universal dos indivíduos. Existam ou não os indivíduos, isto é indiferente para a ordem ética objetiva, que se basta a si mesma. Ela é a força que governa a vida dos indivíduos. Tem sido representada pelas nações como a eterna justiga, Ou como deidades absolutas em confronto com as quais a luta dos indivíduos é um jôgo vazio, como o barulho das ondas." Hegel, Philosphy of Right, trad. por J.W. Dyde (Londres, 1896), pág. 156, \$145, em ad 
despido de quaisquer elementos ideológicos e utópicos. Mas a completa eliminação de elementos transcendentes à realidade, em nosso mundo, nos levaria a uma "constatação de fato" que significaria, em última análise, a decomposição da vontade humana. Neste aspecto reside a mais essencial diferença entre estes dois tipos de transcendência à realidade: enquanto o declínio da ideologia representa uma crise apenas para certos estratos, e a objetividade que nasce do desmascaramento das ideologias sempre assume a forma de um auto-esclarecimento para a sociedade como um todo, a completa desaparição do elemento utópico do pensamento e da ação humanos significaria que a natureza e o desenvolvimento humanos iriam assumir um caráter totalmente novo. A desaparição da utopia ocasiona um estado de coisas estático em que o próprio homem se transforma em coisa. Iríamos, então, nos defrontar com o maior paradoxo imaginável, ou seja o do homem que, tendo alcançado o mais alto grau de domínio racional da existência, se vê deixado sem nenhum ideal, tornando-se um mero produto de impulsos. Assim, ao término de um longo e tortuoso, mas heroico desenvolvimento, justamente no mais elevado estágio de consciência, quando a história vai deixando de ser um destino cego e se tornando cada vez mais uma criação do próprio homem, o homem perderia, com o abandono das utopias, a vontade de plasmar a história e, com ela, a capacidade de compreendê-la. 


\title{
UTOPIAS POR UM MUNDO MELHOR
}

\author{
Adalmir Leonidio ${ }^{1}$
}

\section{Introdução}

O termo utopia é antigo. Ele foi literalmente inventado pelo inglês Thomas More, em seu livro Utopia, no século XVI. Tanto a sua origem quanto a sua utilização ao longo dos séculos sempre foram alvo de muita confusão. Mas foi seguramente com Marx que ele adquiriu seu sentido mais difundido: o de "sonho", "fantasia", "evasão da realidade". Os "utópicos" tirariam de suas cabeças um sistema novo, mais perfeito, de ordem social, para tentar implantá-lo na sociedade ${ }^{3}$. Esta representação da utopia perdurou até o início do século XX. Nos anos vinte, Martin Buber caracterizou a "imagem utópica" como "um quadro do que deve ser", um estado ideal, portanto, mas sem a acepção negativa empregada por Marx e Engels. A utopia anseia pelo que é justo e experimenta, como revelação ou idéia, aquilo que não pode se realizar no indivíduo,

1 Doutor em Ciências Sociais e professor no Curso de História da Universidade Federal Rural do Rio de Janeiro.

2 MARX, Karl. Manifesto do Partido Comunista. In: MARX, K. \& ENGELS, F. Obras escolhidas. São Paulo: Alfa-Omega, s.d., p. 38-43.

3 ENGELS, F. Do socialismo utópico ao socialismo científico. In: MARX, K. \& ENGELS, F. Obras escolhidas. São Paulo: Alfa-Omega, s.d., p. 307. 
mas somente na comunidade humana. A visão daquilo que deve ser não pode no entanto ser separada da atitude crítica em face da atual maneira de ser do mundo ${ }^{4}$.

Partindo de Martin Buber, uma relativização interessante da idéia de "utopia" aparece com Karl Mannheim, em 1929. Segundo o pensador alemão, um "estado de espírito" é utópico quando, simultaneamente, transcende a realidade e assume uma conduta que tende a se opor, seja parcial ou totalmente, à ordem de coisas que prevalece no momento. Neste sentido ele é oposto ao "estado de espírito" ideológico, que, congruente ou incongruente com a realidade, tende a permanecer no nível da realização e da manutenção do status quo ${ }^{5}$.

Mais recentemente, Michel Löwy buscou mostrar que tanto para Marx e Engels, quanto para Mannheim, a utopia era concebida como uma forma de falsa consciência, isto é, uma representação que transcende a realidade. Segundo o autor, ideologia e utopia seriam, ambas, uma visão social de mundo, isto é, um estilo de pensamento ou ponto de vista socialmente condicionado. Uma visão social de mundo será utópica quando circunscrever um conjunto articulado e estruturado de valores, representações, idéias e orientações cognitivas que se oponha à ordem social vigente, propondo a realização, no presente ou no futuro, de uma nova sociedade, ou de reformas que alterem significativamente a sociedade em curso ${ }^{6}$.

Esta definição de Löwy para o conteúdo da utopia encerra, no entanto, alguns problemas. Antes de mais nada, vincular a utopia a uma forma radical de encarar a situação presente, exclui dela

\footnotetext{
4 BUBER, Martin. O socialismo utópico. São Paulo: Perspectiva, 1971.

5 MANNHEIM, Karl. Ideologia e utopia. Rio de Janeiro: Guanabara, 1986, p. 216.

6 LÖWY, Michel. As aventuras de Karl Marx contra o Barão de Münchhausen. São Paulo: Busca Vida,1987.
} 
grande parte da literatura que se convencionou chamar utópica, como More, um erasmista estrênuo, que capitulou frente a propostas mais radicais de reforma, como a de Thomas Müntzer. Por outro lado, segundo esta acepção, todo socialismo seria utópico, no sentido de que é uma visão de mundo que se opõe à sociedade capitalista. O que não é verdade, já que Saint-Simon, por exemplo, não se opôs ao capitalismo industrial de sua época, embora tenha idealizado uma sociedade mais igualitária.

Mas há ainda uma outra questão que foi muito pouco trabalhada pela bibliografia que trata do tema. Isto é, há uma variedade muito grande de utopias - utopias sociais, utopias políticas, utopias religiosas, utopias cientistas, entre outras -, de modo que dificilmente se poderia falar em utopia no singular, e de forma definitiva. Apesar disso, apostamos na hipótese da existência de elementos comuns aos diversos tipos de utopia, ainda que estes elementos se apresentem de forma um tanto diversa nos diferentes contextos históricos. O que este artigo pretende é, admitindo a utopia como um dado conteúdo, perceber os seus elementos constitutivos ao longo da história, suas continuidades e descontinuidades. O seu limite temporal será o período imediatamente posterior à Revolução Francesa, deixando de lado, portanto, toda forma de utopia que se desenvolve a partir do início do século XIX.

\section{A utopia através dos tempos: de Platão a Babeuf}

O Renascimento é o tempo que vê florescer a utopia. Mas se ela pôde então florescer, é porque já era uma planta com sólidas raízes. Por outro lado, sabe-se que esta época é marcada por uma volta à Antiguidade. Já se disse que o Renascimento, como fase de transição para a ciência moderna, colaborou grandemente para solapar as bases do aristotelismo. Foi uma aliança de Platão 
com Demócrito - ou Epicuro - que desmoronou o império de Aristóteles. Portanto, esta volta à Antiguidade é, também, uma revolta contra a Antiguidade e a tradição.

O objetivo de Platão é ensinar a virtude aos cidadãos, isto é, pretende construir uma república feliz através de uma reforma dos indivíduos. Partindo da dialética socrática ele vai tentar definir então o que é a virtude, até elevá-la a um modelo de conduta moral. E aqui já aparece um dos problemas centrais da utopia. Quase no final de seu livro pergunta-se Platão: "É possível executar uma coisa tal como se descreve? Ou está na natureza das coisas que a execução tenha menos influência sobre a verdade que o discurso?"' . Ele acabará por concluir pela segunda hipótese. Isto é, conhecer o Bem é já praticá-lo, uma vez que ninguém o conhece sem o desejar.

Mas por trás deste seu projeto de reforma dos indivíduos também aparece uma outra questão central para os utópicos, e que parece estar contida numa enigmática afirmação de Demócrito (460 - 370 a.C.): "Todos os seres vivos associam-se com seres vivos

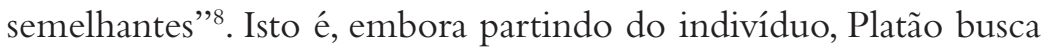
a unidade social.

A Justiça parece ser a principal virtude e o supremo bem de uma república feliz. Para Platão a natureza fez os indivíduos com diferentes aptidões, isto é, aptos para esta ou aquela função. As coisas são feitas em maior número, melhor e mais facilmente, quando cada um, segundo suas aptidões, se entrega a um único trabalho. A Justiça consiste, portanto, em "restituir a cada um o que lhe é próprio". Para o indivíduo, ser vir tuoso é exercer a função que

\footnotetext{
7 PLATÃO. A República. Lisboa: Europa-América, 1998, p. 204.

8 Cf. BORNHEIM, Gerd A. (org.). Os filósofos pré-socráticos. São Paulo: Cultrix, 1993.
} 
lhe cabe na sociedade. A hierarquização das funções sociais é, pois, a condição da harmonia e da concórdia na República platônica ${ }^{9}$.

O ideal para uma república, o seu maior bem é que ela seja una. Para tanto é preciso, em primeiro lugar, que cada indivíduo cumpra a sua função social. Secundariamente, que ela forme uma "comunidade de prazer e de dor". Toda a cidade deve compartilhar a alegria e a tristeza de cada indivíduo, e cada indivíduo não deve ver no outro senão um irmão ou uma irmã. Em seguida, devese suprimir "os dois temíveis inimigos da unidade", o interesse individual e o espírito de família. Suprimir-se-á o primeiro pela comunidade dos bens, o segundo pela comunidade das mulheres e dos filhos. Por fim, é preciso evitar os grandes estados, à maneira do império persa ${ }^{10}$.

Este último ideal de unidade, ancorado no pacifismo, espelha o seu desejo de alcançar a nova república através da simples persuasão, isto é, da não-violência. Como nas utopias que se desenvolverão a partir daqui, Platão deseja ver os reis aconselhados pelos filósofos, os portadores da utopia. $\mathrm{Na}$ alegoria da caverna vê- se claramente que é somente através do saber que se pode tornar a cidade-modelo uma realidade e não um sonho vão, como nas cidades de seu tempo, onde as pessoas se batem por sombras. $\mathrm{O}$ sonho, a ilusão é, portanto, aquilo que existe enquanto ignorância, e não aquilo que se projeta enquanto modelo ideal ${ }^{11}$.

Em Platão, o pensador é acompanhado por um incomparável artista, que a Musa dotou de todos os dons, entusiasmo do belo, imaginação rica, capacidade de sair de si próprio e de criar tipos de toda espécie, fantasia alada. Em dois outros diálogos, Timeu e

\footnotetext{
9 PLATÃO, A República, p. 31-60.

10 PLATÃO, A República, p. 190-193.

11 PLATÃO, A República, p. 205.
} 
Critias, Platão refere-se a uma viagem de Sólon ao Egito, onde este soube que os sacerdotes egípcios de Sais possuíam registros de "uma ilha continental além das Colunas de Hércules (antigo nome de Gibraltar) chamada Atlântida", o centro de um grande e maravilhoso império, que teria desaparecido após "uma grande inundação" ${ }^{2}$. Platão descreve este lugar como sendo o Jardim das Hespéredes, uma das versões gregas do paraíso terrestre ${ }^{13}$.

Mas outra característica interessante na descrição platônica, que depois será quase que uma obsessão entre os utópicos, é o gosto por contar, enumerar, planejar, ordenar. Nesta república ideal havia pontes ligando os principais pontos da cidade que se viam separados por rios e mares. O palácio real ficava no centro, e havia ligações de todos os lugares até ele. Ao redor ficavam as habitações. Os homens e bens circulavam graças a uma complexa rede de canais e estradas que se estendia por toda parte. Havia uma idade ideal para o casamento - vinte anos para as mulheres e trinta para os homens. Os nascimentos eram rigorosamente controlados, a fim de manter estável o número de habitantes ${ }^{14}$. $\mathrm{E}$ a fim de que cada indivíduo chegasse à mesma alta perfeição da cidade, era exercido um rigoroso controle eugênico, estabelecendo-se o número ideal de casamentos.

Mas o que falta à república platônica, como um dos fundamentos de ligação entre os homens, será encontrado em Epicuro, isto é, a doutrina do hedonismo. A moral epicurista está fundada na idéia de que o fim último da vida humana é a felicidade, e que esta só pode ser encontrada no prazer. A razão deve velar para que o

12 O que na tradição bíblica será relacionado ao "grande dilúvio", e a Atlântida a um dos possíveis lugares onde ficaria localizado o paraíso edênico.

13 PLATÃO. Diálogos - vol. XI. Belém: Universidade Federal do Pará, 1975.

14 Em A República, Platão admitia até mesmo o infanticídio. 
prazer seja puro, isto é, não esteja misturado a nenhuma dor. A fim de evitar a insatisfação é necessário limitar os desejos unicamente aos que são "naturais" como, por exemplo, a fome e a sede. Sua frase mais famosa diz "A fonte e a raiz de todo o bem é o prazer do ventre". Epicuro postula uma espécie de harmonia preestabelecida entre as necessidades e os recursos, entre a natureza individual e a natureza universal, de modo que a pobreza não nasce da raridade dos bens, mas da necessidade não-natural, isto é, do supérfluo ${ }^{15}$.

Mas a apologia da harmonia natural em Epicuro está ligada a uma crítica da sociedade, que aparece, pois, como um artificio. Os homens não estão naturalmente destinados a viver em sociedade. A necessidade que nos torna dependentes uns dos outros é uma prova de fraqueza. Obrigado a viver em sociedade, o homem lança mão de vários meios a fim de se preservar. Um desses meios é a justiça, compreendida não como a realização de uma ordem ideal, como em Platão, mas como uma convenção utilitária, feita em vista de não se prejudicar mutuamente.

Durante a Idade Média, um dos seguidores importantes da filosofia platônica, e que vai retomar o seu sentido de justiça e de ordem, é Santo Agostinho (354-430). A sua cidade ideal é a “cidade de Deus", pensada a partir também do modelo da "comunidade cristã primitiva" ". Já para Thomas de Kempis (1380-1471), Jesus é que é o modelo de vida a imitar, exemplo de simplicidade, desapego das riquezas materiais e justiça bem ordenada ${ }^{17}$.

15 Cf. ABENQUE, Pierre. As filosofias helenísticas: estoicismo, epicurismo, ceticismo. In: CHÂTELET, François (org.). A filosofia pagã. Rio de Janeiro: Zahar, 1983, p. 182-190.

16 SANTO AGOSTINHO. A cidade de Deus. Lisboa: Fundação Calouste Gulbenkian, 2000.

17 KEMPIS, Thomas de. A imitação de Cristo. Lisboa: Europa-América, 1998. 
Neste tempo, havia a forte convicção de que a cristandade deveria integrar, se não um Estado, ao menos uma forte unidade, sob o domínio do Papa e do imperador. Havia uma tendência a ver essa idéia expressa claramente no "Reino Universal" parusíaco do profeta Daniel. Apelava-se para a obra A cidade de Deus, embora Agostinho tivesse dado preferência a uma Igreja e a um modelo de redenção não ligados a determinada concepção de império, mas espalhada em uma infinidade de Estados menores, tal como o queria Platão, o que seria mais vantajoso para a paz universal.

Mas o ideal de pacifismo e o de um império mundial eram absolutamente antagônicos, por pelo menos uma questão, com a qual parecia concordar até mesmo Agostinho. O projeto de formar uma única e grande família cristã em todo o globo - o projeto do Orbis christianus -, como condição de realização da paz e da harmonia entre os homens, esbarra com o obstáculo do paganismo. Por isso, muitos serão os críticos de uma tal empresa. Mas muitos serão também os simpatizantes. E entre os continuadores do sonho do império universal está Dante Alighieri (1265-1321).

E até mesmo Agostinho acaba por se render à idéia, ao postular que o universo inteiro é a imagem da ordem admirável em que o mundo material é regido por forças espirituais, isto é, o Papa (o equivalente do rei-filósofo de Platão). E este sonho não cessaria, persistindo século XVI adentro, mesmo e apesar de uma cristandade dividida pela Reforma.

Um desses continuadores famosos foi sem dúvida Nicolau de Cusa, em sua obra Concordatia catholica (1433). Ele preconiza aí a reconciliação das diversas tendências que sacodem a Igreja, em nome da unidade da fé cristã. Naquilo em que ficou conhecido como sua "filosofia da unidade" ele busca analisar como a unidade infinita se espalha em tudo, originando uma espécie de "otimismo unitário" que muito influenciaria a literatura utópica posterior. Foi 
também quem primeiro rompeu com a tradição aristotélica do mundo fechado sobre si mesmo e defendeu a causa do mundo infinito. Tudo se torna possível a partir de então ${ }^{18}$.

Esta dimensão do "tudo é possível" dá novo ânimo ao imaginário utópico que se vinha formando. A literatura de viagem na era dos descobrimentos desenvolve em larga medida o gosto do maravilhoso e do mistério, impulsiona as idéias mágicas e as fantasias típicas do homem renascentista. Colombo (1451-1506) é o viajante que descobre mas, ao mesmo, tempo conta uma história fantástica. Segue-se uma verdadeira caça às terras incógnitas. Neste tempo havia uma firme crença na proximidade do paraíso terreal.

Discutia-se, inclusive, a possibilidade de o Novo Mundo ser a Atlântida redescoberta. E o narrador-viajante genovês, à vista da ilha do Haiti, tem a certeza de nele haver chegado ${ }^{19}$.

Além da crença bíblica no paraíso terrestre, Colombo tem outra idéia fixa, ligar o mundo através da cruz, isto é, concretizar o ideal do Orbis christianus medieval. Para tanto, dois pontos de partida parecem essenciais. Em primeiro lugar, o mapa de Toscanelli, que não só reforça a sua idéia de que o mundo era redondo, mas também que o Oriente esperava a unidade com o Ocidente ${ }^{20}$. Em segundo lugar, os relatos de Marco Pólo, segundo os quais o imperador da Tartária, conhecido como o Grande Cã, pedia que lhe

18 VEDRINE, Hélène. A nova imagem do mundo: de Nicolau de Cusa a Giordano Bruno. In: CHÂTELET, François (org.). A filosofia do mundo novo. Rio de Janeiro: Zahar, 1983.

19 COLOMBO, Cristóvão. Diários da descoberta da América. Porto Alegre: L\&PM, 1991, p. 64.

20 Os utópicos do século XIX desenvolverão este tema a partir da metáfora da junção da Madre (o Oriente, representando o sentimento) com o Padre (o Ocidente, a razão) 
fossem enviados cem teólogos para que assim se iniciasse a conversão dos mongóis.

Mas se ligar o mundo é a grande empresa de Colombo, é só em uma ilha que é possível descobrir (ou inventar) o paraíso terrestre. Até a segunda viagem ele só havia encontrado ilhas, onde justamente são feitos os mais empolgantes relatos. Em sua carta aos reis católicos, referente à sua terceira viagem, onde ele afirma ter a Terra o formato de uma pêra, fica clara a sua idéia de que o paraíso ficava mesmo localizado em uma ilha ${ }^{21}$. Isto parece confirmar a visão do paraíso associado à Atlântida de Platão.

Esta imagem seria retomada por Desidério Erasmo (14671536). O seu livro mais importante, Elogio da loucura (1508), inicia com uma carta "ao amigo Thomas More". Ele começa com a idéia de "jogar" com o nome de More, "que tanto se aproxima do nome grego da loucura (Moria)", deixando-lhe a seguir a incumbência de defendê-la ${ }^{22}$. Fala então a loucura: "Nasci nas ilhas Afortunadas onde as colheitas não exigem sementeira ou esforço" e onde "o trabalho, a velhice e a doença são desconhecidas". As "ilhas Afortunadas" nada mais são do que a Atlântida perdida, para onde todos os olhos se parecem voltar.

Mas o livro é também uma crítica à "razão louca" ou à loucura que se traveste de razão, isto é, o "mundo fechado" dos teólogos escolásticos, os donos de toda a verdade sobre a vida. Esta ciência, a dos doutores da Igreja, aparecia então como um sonho, uma ilusão, tal como em Platão. Assim, Erasmo defende, em contrapartida, a "loucura sã", aquela dos simples e dos justos da "Santa Escritura", que em tudo buscam imitar a Cristo: "A raça simples da idade de

21 COLOMBO, Diários..., p. 189.

22 ERASMO. Elogio da loucura. Lisboa: Europa-América, 1990, p. 10. 
ouro não possuía ciência alguma, apenas o guiava o instinto da natureza".

Os homens mais felizes são, pois, os que conseguem fugir das ciências e ter como guia a simples natureza. Há aqui, portanto, uma profunda descrença quanto à educação e às demais instituições da época para tornar os homens felizes ${ }^{23}$.

Erasmo acreditava que era impossível melhorar a sorte dos povos enquanto os príncipes continuassem em estado de guerra, enquanto o Papa se mostrasse impotente para fundar a paz dos povos cristãos. Mas aqui entra uma importante contradição, pois a paz dos povos cristãos significava necessariamente a guerra aos infiéis, isto é, a defesa do projeto do Orbis christianus.

A moria de More (1477-1535), a sua Utopia (1516), será, pois, esta "loucura sã" de Erasmo. Neste sentido, o fantástico é também um motivo para a sátira. Isto traz ao sentido platônico do modelo e da realização do modelo, um outro contributo importante para o conteúdo da utopia que se vai remodelando. Os utópicos não buscam um retiro fora da realidade, como normalmente se atribui ao sentido de utopia (ou-topos), isto é, "lugar nenhum". Outro sentido possível do termo, e que se confundia no vocabulário da época era, pois, o de eu-topos, isto é, lugar do bem, ou lugar bom demais para ser verdade, mas que é possível. E sua possibilidade deve necessariamente passar pela crítica da utopia em outro de seus sentidos possíveis, isto é, ordem existente ${ }^{24}$.

A narrativa de More desenvolve-se a partir de um diálogo, ao estilo platônico, entre ele próprio, Pedro Giles (seu amigo, natural

23 ERASMO, Elogio..., p. 60-62.

24 MORE, Thomas. Utopia. Lisboa: Europa-América, 1995 
de Antuérpia) e Rafael Hitlodeu, quase todos personagens reais ${ }^{25}$. O seu objetivo é criticar os "vícios" da sociedade inglesa da época de Henrique VIII e definir a "virtude" própria a uma república feliz.

Hitlodeu é o narrador que viajou "como o grande filósofo Platão", tendo acompanhado Américo Vespúcio em três das suas quatro viagens. A comparação não é inocente. Trata-se da postura própria ao narrador-viajante, isto é, para descobrir outro mundo ou para mudar este é preciso viajar como quem deseja conhecer, despido dos preconceitos, tendo, pois, a postura do filósofo. Daí que More e Giles não queiram saber de Hitlodeu a respeito de "monstros famosos", mas das possibilidades de existência de "uma república justa e sabiamente governada".

Nesse sentido, More tenta convencer a Hitlodeu da importância de seus conselhos para o rei, embora desconfiasse dos "preconceitos e crenças firmemente instaladas", isto é, da razão louca de Erasmo, contra a qual acalenta sua "loucura sã": "Se repetisse as teorias que Platão expressa na sua República e que os utopianos põem em prática, embora sejam efetivamente superiores às que nos regem, admito que poderiam parecer estranhas e absurdas"26.

Segue-se uma descrição da ilha da Utopia e do modo de viver dos utopianos que é muito similar àquela de Platão para sua República: comunidade dos bens (mas não das mulheres), uniformidade e regularidade do espaço e dos hábitos, etc. A única diferença é que o trabalho é tido como sumamente importante em seu projeto de valorização do homem em sociedade. Ele deveria

25 Há na bibliografia sobre o tema uma grande discussão sobre a real existência de Rafael Hitlodeu.

26 MORE, Utopia, p. 54. 
estar organizado de tal forma que evitasse que as pessoas permanecessem por muito tempo numa mesma atividade, contrariamente à divisão do trabalho segundo as funções, preconizada pelo filósofo grego. Mas a noção de justiça também estaria fundamentada na noção de hierarquia, já que haveria uma para o povo e outra para uso dos principados. Daí porque More admitisse a existência da escravidão.

Um dos temas centrais do humanismo, que se destacam na obra de More, e que passaria a compor o conteúdo da utopia, é aquele relativo à primazia do homem, que é descrito em termos de possibilidade. A livre determinação do indivíduo ganha precedência sobre uma essência eternamente fixa, rumo à perfeição da comunidade humana na Terra. Ganham relevo temas como o otimismo de perspectiva e o ideal universalista do homem.

$\mathrm{Na}$ ilha de Utopia o desenvolvimento adequado do indivíduo e até mesmo a sua felicidade dependem da sua integração na sociedade.

Um poeta contemporâneo de More, John Donne, expressou de maneira sintética o cerne do problema da utopia moriana ao dizer: "Nenhum homem é uma ilha, completa em si mesma; cada homem faz parte do continente, é uma parte da grande extensão". A ilha é, portanto, uma metáfora para pensar isto que será, depois, a base do liberalismo burguês, isto é, a ficção do indivíduo autosuficiente, nascendo sozinho, em estado de natureza. Mas, é claro, esta questão ainda não estava posta, ao menos com esta amplitude, na época de More. Mas havia a consciência de que o homem é um ser social e todas as coisas são definidas por sua função e atividade dentro da comunidade. Por outro lado, havia a consciência do enorme abismo que separava pobres e ricos. Daí que a ilha seja sempre cotejada por outro modelo toponímico, isto é, o globo, o 
mundo. Portanto, é somente com More que podemos perceber claramente desenhada, pela primeira vez, uma utopia de tipo social.

O outro tema central do humanismo é o culto do belo, também influenciado pela filosofia platônica. More pede a Hitlodeu que the conte tudo o que ele pensasse que lhe daria "prazer conhecer”. Há, portanto, uma importante dimensão estética na literatura do maravilhoso que deve ser salientada.

Este é também o tema desenvolvido por Rabelais (14831565). Embora seja difícil caracterizar o conteúdo de sua literatura como utópico, há elementos inegáveis de utopia. Em Gargantua (1535), a cidade de Théleme, que em grego significa desejo, vontade, nos introduz em um mundo utópico, espaço de fantasia, e descreve uma civilização luxuosa e refinada, onde as artes aplicadas embelezam a vida cotidiana. Mas ela põe ao mesmo tempo a sociedade de pernas para o ar, ao construir um modelo que pensa ser os atípodas da outra. É a livre determinação e o hedonismo que levam os indivíduos à felicidade. Falando dos habitantes deste novo mundo, acrescenta Rabelais: “Toda sua vida está regrada não por leis, status, ou regras mas sim por seu desejo e livre arbítrio. Come-se, trabalha-se, dorme-se quando se deseja" ${ }^{27}$.

Em Le tiers livre (1546), Rabelais continua o esquema de viagens longínquas para países exóticos ou imaginários. O primeiro capítulo narra como Pantagruel (personagem central) transporta uma colônia de utopianos para Dpsódia. A noção que domina o livro é a do bem-querer recíproco, da assistência mútua. Isto explica o lirismo com que o personagem Panurge celebra a idade de ouro, onde cada um dá e recebe conforme a "lei universal da natureza" 28 . Também em Le cinquiéme livre (1548), ele encontraria uma ilha

27 RABELAIS, François. Gargantua. Paris: Flammarion, 1993, p. 232.

28 RABELAIS, François. Le tiers livre. Paris: Gallimard, 1966. 
onde "as árvores e as ervas não perdem jamais as folhas" ${ }^{29}$, tal qual a visão do paraíso descrito por Colombo ao encontrar o Haiti.

O culto ao belo também se equipara ao elogio do instinto em Michel Montaigne (1533-1592). Em seu ensaio Dos canibais (1579), ele critica o discurso corrente sobre a barbárie dos índios, e questiona simultaneamente os costumes dos europeus. A simplicidade natural daqueles, relacionada a uma pretensa condição humana feliz, é contraposta aos artificios culturais da civilização européia, que sufocam a beleza e a riqueza da natureza. O mero exemplo prático dessas tribos sobrepuja todas as descrições "com que a poesia embelezou a idade de ouro". E referindo-se a Platão, acrescenta: "A república que ele imaginou, como a consideraria distante dessa perfeição" ${ }^{30}$.

Mas o relativismo de Montaigne e o elogio do homem em estado de natureza não renuncia ao paradigma humanista de uma unidade do gênero humano. Foi o rompimento da identidade natural, com a vontade de domínio da razão, que confundiu e perturbou a fisionomia das coisas. Mas ele renuncia sem dúvida ao ideal do Orbis christianus. Está-se inaugurando uma nova era da utopia, e este modelo já não parece imperar sem rivais.

29 RABELAIS, François. Le cinquiéme livre. Paris: Éditions du Seuil, 1997, p. 237.

30 MONTAIGNE, Michel. Os ensaios: livro 1. São Paulo: Martins Fontes, 2001, p. 309. 
Giordano Bruno entra na briga pela diversidade, pela relatividade e abre ainda mais o mundo, dilatando a espaços sem fronteiras a utopia. A possibilidade de "descobrir" ou de "inventar" outros mundos ganha o infinito, e extrapola o topônimo da ilha. O principal livro de Bruno, Sobre o infinito, o universo e os mundos (1580), escrito sob a forma de diálogo, estabelece a inconveniência e a "impossibilidade" de "imaginar" o mundo como existindo em "lugar nenhum". Todas as coisas significam lugar. Assim, um outro mundo é possível, no duplo sentido da palavra. Um mundo diferente daquele estabelecido pelos cânones filosóficos do aristotelismo, mas também daquele ordenado pela Igreja e pela aristocracia. Isto revela também as intenções satíricas da obra de Bruno, que ao ser interrogado sobre as suas intenções de pôr o mundo "de cabeça para baixo", responde: "Considera você errado alguém inverter um mundo virado às avessas" ${ }^{1}$.

Outra novidade importante em Bruno é que ele reanima o animismo epicurista, através da crença em um universo infinito, povoado por infinitos corpos dotados de vida própria. Em sendo assim, tudo está em perpétuo movimento, tudo se renova e se recompõe, estando sujeito a um ótimo eficiente. A doutrina segundo a qual "os contrários existem nos contrários" e que "cada coisa é composta de todas as coisas" estabelece as bases para se pensar a harmonia no universo: "Desta diversidade (de mundos) e oposição dependem a organização, a simetria, a compleição, a paz, a concórdia, a composição, a vida" ${ }^{32}$.

Mas Bruno não descarta o deismo. Isto é, tudo vem do bom, tudo é bom, pelo bom e para o bom, o que resume a excelência de

31 BRUNO, Giordano. Sobre o infinito, o universo e os mundos. São Paulo: Abril Cultural, 1973, p. 63 (Col. "Os Pensadores", vol. 12).

32 BRUNO, Sobre..., p. 63. 
Deus. $\mathrm{O}$ arquiteto do universo e a sua bela ordem podem agora ser contemplados não apenas neste mundo, mas em infinitos outros. Isto introduz uma certa contradição com os fundamentos satíricos da obra de Bruno.

De qualquer forma, não se configura na utopia um simples abandono da vida corrupta para se entregar ao devaneio em suas margens, conforme a crítica corrente.

No prólogo do tradutor espanhol da obra de Traiano Boccalini (1556-1613), Notícias do Parnaso (1605), percebe-se esta maneira dissimulada de falar de coisas perigosas, mas também as suas intenções estéticas: "Este autor é um entre tantos outros que têm escrito neste gênero de mesclar o útil dos conselhos políticos com o gostoso e entretido da invenção" 33 . Trata-se aqui claramente de uma utopia de tipo político.

Está-se, portanto, sempre retomando o problema do modelo formulado por Platão. Tommaso Campanela (1568-1639), em sua obra clássica A cidade do sol (1605), tenta responder a duas objeções normalmente levantadas em seu tempo com respeito a esta questão. Em primeiro lugar, a objeção segundo a qual do que nunca existiu, nem existirá, nem se espera que exista, é inútil e vão tratar. Em segundo lugar, a de que tais modelos são mais conformes à natureza do que provado pelos usos e costumes das nações. A isto o utópico italiano responde que a República de Platão não poderia ser posta em prática apenas pela natureza corrupta do homem. Mas ela existe e pode existir no "estado de inocência", isto é, aquele prefigurado pelas comunidades indígenas da América e aquele a que "Cristo nos faz voltar".

33 BOCCALINI, Traiano. Discursos politicos y aviso del Parnaso. Madrid: Maria de Quinoñes, 1634. 
Assim, a verdade do Evangelho estaria de acordo com o estado de natureza. Isto o provaria ainda as antigas comunidades cristãs e o exemplo dos anabatistas ${ }^{34}$.

A partir daqui começa a desenhar-se com mais nitidez a idéia de buscar na ordem natural, tida como o ideal de uma ordem perfeita, o modelo da ordem para a sociedade. Por essa altura Galileu já tinha exposto suas principais teorias e, portanto, qualquer modelo que se formulasse tomando por referência a natureza, acabaria por se confrontar com o problema da nova ciência e da técnica que se iam vagarosamente desenhando.

E é um discípulo de Campanella quem vai trazer esta novidade para o seio da utopia. Trata-se de Francis Bacon e de seu livro Nova Atlântida (1610). O narrador- viajante, navegando por mares desconhecidos, encontra uma ilha, onde habitava um "povo culto", de "alta humanidade" e "cristãos".

Era a Atlântida, império poderoso em cujo centro encontrava-se a "Casa de Salomão"35, instituição científica que tem por objetivo o "alargamento das fronteiras do império humano, para realizar tudo quanto for possível"36. Este é o preciso momento em que as razões do império deixam de ser religiosas e passam a ser científicas. Ao invés do Orbis christianus, busca-se agora o Orbis cientificus, um mundo perfeitamente dominado e unido pelo poder da ciência. Está-se diante, portanto, de uma utopia de tipo cientificista.

Há um tom profético nas descrições do poder científico e tecnológico da "nova Atlântida".

34 CAMPANELLA, Tommaso. A cidade do sol. Lisboa: Guimarães, 1996.

35 Isaac Newton também falará a respeito de uma tal "casa” em sua obra O templo de Salomão.

36 BACON, Francis. Nova Atlântida. Lisboa: Minerva, 1976, p. 60. 
Entre as inovações merecem destaque a "capacidade de transmitir sons das mais diferentes distâncias" e a "capacidade de imitar vôos de aves", bem como de criar "navios e barcos para navegar debaixo da água". E o desejo de pôr a ciência no lugar da religião, chega ao ponto de fazer da ciência uma nova forma de religião:

"Para os nossos rituais e cerimônias dispomos de duas galerias muito compridas e grandes. Numa delas colocamos padrões e amostras de toda a sorte das mais raras e excelentes invenções; na outra, as estátuas de todos os principais inventores. Temos lá a estátua do vosso Colombo, que descobriu as Índias Ocidentais." 37

Tido por alguns como um texto de antecipação ou mesmo de divulgação científica, a História cômica, de Cyrano de Bergerac (1620-1655), marca um momento importante nesta transformação do conteúdo da utopia ${ }^{38}$. O cômico francês fazia parte do grupo dos chamados "libertinos eruditos", tendo sido aluno, juntamente com Moliére, do epicurista e sensualista Pierre Gassendi (1592-1655), considerado por seus contemporâneos como um dos maiores sábios de seu tempo.

A obra compõe-se de duas partes, uma que narra uma fantástica viagem à lua, outra ao sol. A crença na existência de outros mundos ainda era algo burlesco na época de Bergerac, ao mesmo tempo que podia levar para a fogueira, daí que ele compôs a fábula como uma história cômica, que era uma maneira dissimulada de falar destas coisas. Ele desenvolve temas comuns à nova cosmologia científica, sobretudo aqueles relacionados à relatividade dos lugares e dos movimentos.

37 BACON, Nova..., p. 77.

38 BER GERAC, Cyrano. História cômica ou Viagem à lua. Porto: Leiauto, 1989; e Los paraísos posibles: noticias del outro mundo. Bogotá: Altamir, 1996. 
A possibilidade de voar através do espaço em uma máquina é uma fantasia comum à época. Leonardo da Vinci elaborou o que seria o protótipo de um helicóptero, enquanto que François Godwin, em seu livro O homem na lua (1638), projetou um rudimentar artefato que seria elevado por gansos até o céu infinito. Mas Bergerac inspira-se também no bíblico "carro de Elias"39.

Sua cosmologia está muito mais próxima do animismo de Bruno do que da teoria do movimento desenvolvida por Galileu. Assim, para ele, no universo os corpos semelhantes tendem a juntar-se por "simpatia", "por esse princípio desconhecido de amor através do qual experimentamos que cada coisa busca seu semelhante". Este misto de ciência e fantasia, mostra bem a importância da contribuição renascentista para a composição do conteúdo da utopia.

A dimensão do possível, do onírico, o gosto do maravilhoso, a qualidade mágica são traços que persistem. Um exemplo disto é a possibilidade de reencontrar o Éden bíblico. Em sua versão do paraíso, Bergerac mescla a tradição mitológica grega, do Jardim da Hésperedes, que ele cita no final de sua viagem ao sol, e a tradição judaico-cristã, sobretudo Dante e Ariosto (1474-1533), que o localiza na lua. Não obstante esta referência às tradições do "velho mundo", as intenções satíricas são claras. Pondo o mundo pelo avesso, ele descreve a lua como os antípodas da Terra.

Duas outras novidades, relativamente ao conteúdo da utopia, marcam a obra de Bergerac. Em primeiro lugar, o desaparecimento do filósofo enquanto aquele personagem que aconselha o

39 Posteriormente iriam aparecer várias obras que narram experiências similares, cujo grande exemplo é O descobrimento austral por um homem voador (1781), de Rétif de la Bretone (1734-1806), que será seguido por Júlio Verne (1828-1905). 
rei. O narrador-viajante agora aconselha-se apenas a si mesmo, ou no máximo propõe-se como modelo de conduta para os indivíduos. Durante toda sua viagem ao sol, ele é acompanhado pelo "Demônio de Sócrates", personagem platônico que prefigura a voz interior que lhe faz saber o sentido moral da sua ação. Com reis "tão estúpidos" era impossível reformar o mundo. Há inclusive um ensaio de regicídio ${ }^{40}$.

Em segundo lugar, aparece um problema já levantado por Montaigne, que insere uma importante reflexão a respeito da natureza má do homem, ou de sua tendência para fazer o mal. No sol o narrador-viajante é preso e condenado por descobrirem que ele é homem, "uma calamidade" ante a natureza, uma "peste que deve ser excluída de toda sociedade bem ordenada". Só na Terra, isto é, nas sociedades humanas cujo modelo era a Europa de seu tempo, poderia haver a dominação do mais forte sobre o mais fraco, do homem sobre a natureza, do rico sobre o pobre. Até mesmo o império do Orbis cientificus é então questionado, à medida que ele é contrário às "leis da natureza", diante das quais todos os homens são iguais. Isto põe uma séria interrogação para o otimismo humanista que se vinha desenvolvendo.

Esta tendência de crítica aos valores de civilização, não obstante o relativo entusiasmo pela ciência, ganha um poderoso aliado em Fénélon (1651-1715), em sua obra Aventuras de Telêmaco (1702). Telêmaco, filho de Ulisses, que é o narrador da história, após viajar de ilha em ilha, encontra Betica. "Naquele país ainda parece se conservam as delícias da idade de ouro".Admira-se com

40 Veremos que à medida que a idéia de monarquia for perdendo força na Europa, mais este modelo tende a ser raro. Na era das "Luzes" falar-se-á em reformas feitas pela sociedade civil, enquanto que no século XIX será o sábio, imbuído da ciência, quem deverá cumprir esta missão. 
a vida "simples" e "feliz" que os habitantes levavam. A base da concórdia entre homens era a "inocência dos costumes" e a "boa fé" de cada um. Para além disso, não havia motivos para a concorrência, uma vez que a natureza tudo ofertava, e em abundância. Ao elogio do estado de natureza, corresponde uma corrosiva crítica à civilização, que amolece, afemina, torna as pessoas feias, estimula o luxo, o supérfluo e alimenta a ociosidade ${ }^{41}$.

Este mesmo jogo entre vícios e virtudes, de uma civilização que se mostra cada vez mais bárbara e de um imaginário estado de natureza que seria o ideal de convívio entre os homens, vai-se encontrar em Denis Diderot (1713-1784), Supplément au Voyage de Bougainville (1748). O livro é inspirado no relato de Louis Antoine de Bougainville (1729-1811), navegador francês que deu a volta ao mundo. Quando chega ao Taiti, assim como Colombo quando chegou ao Haiti, maravilha-se pensando ter chegado ao próprio paraíso. O relato, Voyage autour du monde, ressalta, sobretudo, o ideal comunitário que reinava entre os índios.

Tal como More que se viu maravilhado com os relatos de Colombo e Vespúcio, iniciando logo a seguir sua Utopia, Diderot não conseguiu conter seu entusiasmo. A história narra o diálogo entre dois personagens, "A" e "B", a respeito do referido relato de viagem. Voltam alguns dos temas já presentes em Fénélon, mas aqui eles são mais explícitos. A civilização européia aparece como uma "máquina complicada e corrupta", em contraposição à "juventude", ao "frescor", à vida "simples", "feliz" e "livre" dos "selvagens". A palavra liberdade aqui aparece como anátema de propriedade e servidão em um duplo sentido: em relação aos bens

41 Estas idéias estão na raiz do romantismo utópico que se desenvolverá posteriormente, e que vê no progresso capitalista um fator de destruição do meio e do homem. 
e às mulheres. Na comunidade dos taitianos ninguém é proprietário de nada nem de ninguém ${ }^{42}$.

A inocência dos selvagens aparece como a ignorância que é sabedoria, o saber viver, em contraposição às "luzes inúteis", que são ignorância e loucura. Eles medem-se apenas pelo que é necessário e bom para a comunidade, por suas "necessidades naturais", nunca pelo interesse individual. Também sua "beleza", sua saúde, força, destreza e coragem são reflexos desta sabedoria, que é conforme as "leis da natureza" e a base das "leis civis" entre eles. Portanto, os taitianos são um povo de "bons costumes" e "altamente civilizado", ao contrário dos europeus.

Ao fim do diálogo "A" pergunta a "B": "Que fazer então? Retornar à natureza?”. E "B" responde: "Há que falar contra as leis insensatas até que haja reforma". Se é impossível negar o estatuto de civilizado e retornar ao simples estado de natureza, é possível construir uma civilização melhor, desde que se tome como modelo as "leis da natureza". Este ponto marca também o início do reformismo ilustrado como um ideal entre os utópicos ${ }^{43}$.

Mas a precedência da Humanidade sobre os homens, do globo sobre a ilha, no que se fundamentava o otimismo dos utópicos, parece esbarrar com a possibilidade da barbárie. Com Jean-Jacques Rousseau o tema ganha novos argumentos. Em contraposição à natureza, reino da igualdade e da concórdia, aparece a sociedade, geradora de todas as desigualdades e vícios. No estado de natureza o bem-estar e a conservação individual é minimamente prejudicial à outrem. Isto porque o "homem natural" tem repugnância ao ver morrer ou sofrer o seu semelhante. Isto é, o homem, por

42 DENIS, Denis. Supplément au voyage de Bougainville.Paris: Le Livre de Poche, 1995.

43 DENIS, Supplément..., p. 96. 
natureza, só reconhece no outro a sua própria humanidade. A conservação de cada um importa ao todo a que pertencem. Mas como os homens atingiram aquele ponto em que os obstáculos que prejudicam a sua conservação no estado de natureza levam a melhor sobre as forças individuais para se manter neste estado, o único meio de se conservarem passa a ser a associação, isto é, a alienação de cada indivíduo a toda a comunidade ${ }^{44}$.

Em Rousseau é impossível deduzir a ordem social a partir da ordem natural, por mais doloroso que isso lhe seja, pois esta é a própria negação daquela. Fica o eterno sentimento de perda, a nostalgia e uma turva esperança quanto ao futuro.

O mesmo não acontece em Morelly, em seu Código da natureza (1755). Esta é a primeira obra em que o conteúdo da utopia encontrado na literatura precedente ganha o estatuto de um sistema de pensamento, que será depois a base da doutrina do chamado socialismo utópico. Mas o livro parte de um romance, A Basilíade, onde o autor desenha uma sociedade baseada na doutrina comunista. O subtítulo é em si muito significativo "o naufrágio das ilhas flutuantes", isto é, a imersão da ilha no continente, a vitória definitiva do globo. De fato, doravante raros serão os romances utópicos que farão menção à alegoria da ilha ${ }^{45}$.

O livro está organizado segundo cinco teses fundamentais. A primeira delas retoma Rousseau: o homem não nasce nem bom nem mau. Não há valores inatos. São as instituições que corrompem ou educam o homem para o bem. Isto é, não existe mal físico no mundo, o mal é apenas moral. O homem só nasce com suas

44 ROUSSEAU, Jean-Jacques. Discurso sobre a origem e fundamentos da desigualdade entre os homens. Lisboa: Europa-América, 1995; e O contrato social. Lisboa: Europa-América, 1999.

45 MORELLY. Código da natureza. São Paulo: Unicamp, 1994. 
necessidades e seu amor-próprio, seu desejo de conservar-se. Mas a natureza distribuiu as forças aos homens em diferentes proporções, de modo que eles necessitem de se associar para superar a fraqueza das partes. Portanto, a associação não é um artifício da sociedade, como em Rousseau.

Segunda tese: "O mundo é uma mesa guarnecida o suficiente para todos os convivas" 46 . Portanto, a primeira instituição que corrompeu o estado harmônico com que a natureza predispôs a sociedade dos homens foi a propriedade, argumento ao qual Rousseau também não chega. Os dois meios capazes de corrigir este estado vicioso é pondo fim às duas instituições geradoras dele: a propriedade e a educação fundada sobre as ruínas das "leis da natureza". Mas aqui entra uma contradição que é comum a Rousseau, isto é, o estado de natureza pode e deve ser melhorado pela civilização, tornando os "selvagens" "menos grosseiros" e "mais industriosos" como, por exemplo, através do ensino do cultivo da terra e da criação do gado.

A terceira tese estabelece que todo contrato, por sua artificialidade, apenas dá origem a uma sociedade, mas não a um todo unido e coeso. Ele é no fundo uma corrupção do "estado primitivo dos povos", onde predominava a reunião de "famílias associadas", e onde os indivíduos obedeciam apenas "às leis de um sentimento de afeto e ternura suscitado e fomentado pelo exemplo do chefe entre seus irmãos e próximos, doce autoridade que torna todos os bens comuns entre eles" ${ }^{47}$. Foi o fim do "império paternal" e dos "laços de consangüinidade" que originou toda a desordem e a ruína de toda forma de sociabilidade.

46 MORElly, Código..., p. 28.
47 MORElly, Código..., p. 50. 
A quarta tese postula e busca responder a seguinte questão: como ordenar, de acordo com as leis da natureza, as desigualdades naturais dos homens, de modo a formar um todo harmonioso e coeso? "Direi que tudo isso seria uma simples questão de enumeração de coisas e pessoas, uma simples operação de cálculo e combinação, e, portanto, passível de uma belíssima ordem". E sobre que base seria feita esta combinatória? A partir de uma operação de coordenação das diferentes funções sociais, de acordo com as forças próprias com que a natureza dotou cada indivíduo. A associação, a ligação potencia a ação de cada membro individual da sociedade, assim como o organismo humano funcionando em uníssono potencia a ação de cada órgão. Esta é a primeira vez que, entre os utópicos, aparece uma comparação desta natureza, entre o social e o biológico, a partir de uma suposta ordem natural ${ }^{48}$.

A quinta tese introduz um certo sentido da hierarquia que vinha sendo perseguido pelos utópicos desde More: "O todo vale mais do que a parte, mesmo a melhor; a humanidade inteira vale mais do que o melhor dos homens, e uma nação é preferível à mais respeitável família e esta ao mais respeitado dos cidadãos" ${ }^{49}$. Isto reflete-se na obsessão de Morelly pela regularidade, pela organização, pela uniformidade, pela ordenação, seja do espaço, seja da vida das pessoas, o modo de se vestir, de produzir, de distribuir, a idade ideal para casar, quantos filhos ter, etc. Enfim, nenhum esforço é poupado a fim de apagar da sociedade todas as marcas do individualismo, sinônimo de corrupção.

Mas Morelly só vê o mal fisico no mundo civilizado, uma decorrência quase mecânica do mal moral. O que não é exatamente o otimismo metafisico de Leibniz, segundo o qual o homem vive

\footnotetext{
48 MORELLY, Código..., p.54.

49 MORELLY, Código..., p. 67.
} 
no melhor dos mundos. O mundo civilizado chega a ser mesmo o pior dos mundos.

É contra este otimismo leibniziano que Voltaire (1694-1778) se insurge em seu romance Cândido (1758). Mas a obra é simultaneamente uma crítica ao pessimismo daqueles que viam no homem um ser malvado e infeliz. Portanto ele vai partir das mesmas bases de raciocínio definidas por Rousseau e Morelly, isto é, que o homem não nasce nem bom nem mau. Com a diferença de que ele se recusa a ver na natureza qualquer sinal de bondade. Mal e bem são realidades eminentemente sociais.

Cândido, o herói da narrativa, "dotado pela natureza das melhores qualidades", como a ingenuidade e a pureza, e ao mesmo tempo educado no "mais belo e agradável dos castelos do mundo", recebe suas lições de Pangloss, o "filósofo zarolha", encarnação grotesca do otimismo de Leibniz.

Cândido é bom, confia nos homens e em sua bondade natural. $\mathrm{E}$, às vezes, até encontra pessoas dispostas a ajudar e ser solidárias, como o médico anabatista Tiago e a velha que cuida de suas feridas e dá-lhe abrigo e comida. Mas em suas aventuras (e desventuras) pelo mundo é com o mal físico (catástrofes naturais, como o terremoto de Lisboa) e moral (o ódio, a injustiça, a opressão do homem pelo homem, a rapina; como, por exemplo, as pessoas que se aproveitam do terremoto para roubarem e pilharem as casas) que ele vai esbarrar constantemente.

Cansado de ver tanta maldade e desgraça pela Europa parte para o "Mundo Novo", na esperança de lá encontrar a ordem perfeita. Mas aí sofre sua segunda decepção. É quase comido pelos canibais do Paraguai e está prestes a renunciar a filosofia de seu mestre: "Ah, o que diria Pangloss, se visse como é feita a natureza 
pura dos selvagens!" ${ }^{50}$. Extenuado, Cândido adormece numa jangada e quando acorda depara-se com um lugar maravilhoso, paradisíaco, era o Eldorado, onde finalmente foram recebidos e muito bem tratados pelos habitantes. É, portanto, somente através dos sonhos que é possível encontrar um lugar onde tudo vai bem.

Ao deixar o paraíso pela segunda vez, já que a primeira fora quando expulsaram- no do castelo, conclui que a única coisa boa deste mundo era rever a menina Cunegundes, que prefigura o amor e a esperança. E é somente por ela que ele acredita ser possível continuar em suas desventuras pelo mundo. Ao fim, Pangloss já não acredita nas próprias posições, embora acreditasse fosse preciso mantê- las. Cunegundes, embora já "velha e horrivelmente feia", continua sendo o grande amor de Cândido. E o trabalho comum é a única maneira de mantê-los unidos e confiantes no futuro: "O que sei é que é preciso cultivar o nosso jardim"

O livro de Voltaire não é, pois, uma distopia, mas uma revitalização da idéia do sonho como fator construtivo. Não há ordem nem na natureza nem na sociedade e o melhor dos mundos é uma quimera impossível. Mas um mundo melhor é possível. E ele inclusive pode ser o pior dos mundos, pois não há como prever. Tudo o que há é a esperança e a disposição para trabalhar e torná -lo melhor.

No final do século XVIII tais utopias sociais encontrariam em Gracchus Babeuf (1760-1797) um defensor radical: "Tudo corre o melhor possível, diz-se. Sim, para os aristocratas e os inimigos da liberdade. Uma enorme carestia faz sofrer e morrer de fome o operário pobre". Por esta altura já havia ocorrido a Revolução Francesa, onde muitos depositaram as suas esperanças de um

50 VOLTAIRE. Cândido. Lisboa: Europa-América, 1987, p. 67.

51 VOLTAIRE. Cândido, p. 145. 
mundo mais igual e fraterno. Mas, uma vez mais, a realidade contradisse os sonhos e Babeuf interroga-se, um tanto cético: "Onde está o bem que o novo regime já nos proporcionou?" 52 .

A grande novidade que Babeuf traz para o conteúdo da utopia é o seu igualitarismo radical. Antes criticava-se os excessos da civilização, o consumo supérfluo, o luxo, o desperdício, mas sem identificá-lo a qualquer camada da sociedade. Agora eles são identificados com uma minoria ociosa - a aristocracia, o clero - que goza, enquanto a maioria dos "trabalhadores" e "camponeses” vivem na penúria. Neste sentido, Babeuf não considera nem mesmo as diferenças naturais, já que em ao menos um sentido eles são radicalmente iguais, isto é, na "capacidade de seu estômago". A propriedade só diz respeito ao trabalho que o gera. Portanto, tudo que é produzido pela sociedade é da sociedade como um todo.

Cético quanto ao contrato social, Babeuf recai no argumento da ordem natural como prefiguração da ordem social, um dos principais argumentos dos diferentes tipos de utopia:

"Estou convencido que o estado de comunidade é o único justo, o único bom, o único conforme aos puros sentimentos da natureza, e que, fora dele, não podem existir sociedades pacíficas e verdadeiramente felizes (...) Se é assim que as coisas se passam, não consigo ver por que motivo a possibilidade eventual de um regresso ao estado comunitário há-de ser apenas um sonho." ${ }^{53}$

\section{Conclusão}

5252 BABEUF, Gracchus. O tribuno do povo. Lisboa: Iniciativas Editoriais, 1977, p. 24 e p. 35.

53 BABEUF, O tribuno..., p. 72 e p.75. 
A imagem da utopia como mero sonho, fantasia ou evasão da realidade, não parece mais ser aceita pelos estudiosos do tema. Tampouco ela parece revelar-se exclusivamente através do seu conteúdo revolucionário. Ao longo dos séculos, desde Platão, houve um número muito grande de utopias, correspondentes aos diferentes contextos em que tais literaturas se viram nascer.

Mas o que permite então falar em utopia como um dado conceito, uma realidade ou conteúdo que perpassa todas estas diferentes manifestações literárias? Conforme vimos, a mundividência utópica revela uma série de elementos comuns: o modelo e a realização do modelo; a busca da unidade social e de uma sociedade harmônica e concorde, onde o todo é mais importante que as meras partes constituintes e conflitantes; enfim, a busca de uma ordem perfeita. Cada utópico, em diferentes momentos, elaborou estes conteúdos de forma distinta: Platão, através de uma perfeita hierarquização das funções sociais; Morelly através de uma imitação da ordem natural por parte da ordem social; Babeuf através de uma radicalização do conteúdo igualitário dos princípios da Revolução Francesa, e assim por diante.

Mas o sentido mais importante e atual talvez seja o não conformismo, a não aceitação de nenhuma realidade como definitiva, a não ser aquela que eleve ao mais alto grau as potencialidades humanas, isto é, o otimismo de perspectiva e o ideal universalista do homem. Conforme a mensagem de Cândido, personagem de Voltaire, hoje repetida entre aqueles que ainda acreditam em alguma forma de utopia, "um mundo melhor é possível". 


\section{Bibliografia}

ABENQUE, Pierre. As filosofias helenísticas: estoicismo, epicurismo, ceticismo. In: CHÂTELET, François (org.). A filosofia pagã. Rio de Janeiro: Zahar, 1983, p. 182-190.

BABEUF, Gracchus. O tribuno do povo. Lisboa: Iniciativas Editoriais, 1977. BACON, Francis. Nova Atlântida. Lisboa: Minerva, 1976.

BERGERAC, Cyrano. História cômica ou Viagem à lua. Porto: Leiauto, 1989.

BER GERAC, Cyrano. Los paraísos posibles: noticias del outro mundo. Bogotá: Altamir, 1996. BOCCALINI, Traiano. Discursos politicos y aviso del Parnaso. Madrid: Maria de Quinoñes, 1634. BORNHEIM, Gerd A. (org.). Os filósofos pré-socráticos. São Paulo: Cultrix, 1993.

BRUNO, Giordano. Sobre o infinito, o universo e os mundos. São Paulo: Abril Cultural, 1973. BUBER, Martin. O socialismo utópico. São Paulo: Perspectiva, 1971.

CAMPANELLA, Tommaso. A cidade do sol. Lisboa: Guimarães, 1996.

COLOMBO, Cristóvão. Diários da descoberta da América. Porto Alegre: L\&PM, 1991. DENIS, Denis. Supplément au voyage de Bougainville. Paris: Le Livre de Poche, 1995.

ENGELS, F. Do socialismo utópico ao socialismo científico. In: MARX, K. \& ENGELS, F. Obras escolhidas. São Paulo: Alfa-Omega, s.d. 
ERASMO. Elogio da loucura. Lisboa: Europa-América, 1990.

KEMPIS, Thomas de. A imitação de Cristo. Lisboa: Europa-América, 1998.

LÖWY, Michel. As aventuras de Karl Marx contra o Barão de Münchhausen. São Paulo: BuscaVida, 1987.

MANNHEIM, Karl. Ideologia e utopia. Rio de Janeiro: Guanabara, 1986.

MARX, Karl. Manifesto do Partido Comunista. In: MARX, K. \& ENGELS, F. Obras escolhidas. São Paulo: Alfa-Omega, s.d.

MONTAIGNE, Michel. Os ensaios: livro 1. São Paulo: Martins Fontes, 2001. MORE, Thomas. Utopia. Lisboa: Europa-América, 1995.

MORELLY. Código da natureza. São Paulo: Unicamp, 1994. PLATÃO. A República. Lisboa: Europa-América, 1998.

PLATÃO. Diálogos - vol. XI. Belém: Universidade Federal do Pará, 1975. RABELAIS, François. Gargantua. Paris: Flammarion, 1993.

RABELAIS, François. Le cinquiéme livre. Paris: Éditions du Seuil, 1997. RABELAIS, François. Le tiers livre. Paris: Gallimard, 1966.

ROUSSEAU, Jean-Jacques. Discurso sobre a origem e fundamentos da desigualdade entre os homens. Lisboa: Europa-América, 1995. 
ROUSSEAU, Jean-Jacques. O contrato social. Lisboa: EuropaAmérica, 1999.

SANTO AGOSTINHO. A cidade de Deus. Lisboa: Fundação Calouste Gulbenkian, 2000.

VEDRINE, Hélène. A nova imagem do mundo: de Nicolau de Cusa a Giordano Bruno. In: CHÂTELET, François (org.). A filosofia do mundo novo. Rio de Janeiro: Zahar, 1983.

VOLTAIRE. Cândido. Lisboa: Europa-América, 1987. 


\section{UMA UTOPIA DA PRESENÇA: SITUANDO MUNDOS DESEJADOS NOS LUGARES, ESPAÇOS E SOCIEDADES EM QUE VIVEMOS ${ }^{1}$}

Nicole Aguilar Gayard²;

Mylène Tanferri ${ }^{3}$;

Benjamin Raimbault ${ }^{4}$;

Zara Mirmalek ${ }^{5}$

\section{Introdução}

No século XVI, Thomas More retratou uma sociedade perfeita, localizada numa ilha denominada "Utopia". Esta sociedade se inspirava na sociedade inglesa da época, em relação à qual

1 Ensaio redigido durante período em que os autores estiveram vinculados como Pesquisadores visitantes ao programa "Science, Technology \& Society " da Universidade de Harvard.

2 Mestre e Doutoranda em Política Científica e Tecnológica, com enfoque nos Estudos Sociais da Ciência e Tecnologia, pela Universidade Estadual de Campinas.

3 Doutoranda em co-tutela, Universidade de Lausanne, Laboratório de Culturas e Humanidades Digitais e Universidade Federal da Bahia, Instituto de Ciência da Informação.

4 Doutorando no Institut National de La Recherche Agronomique, Sciences t Société.

5 Pós-doutoranda do Programa Science, Technology \& Society, Universidade de Harvard. 
constituía uma visão oposta e aperfeiçoada. Na Utopia de More, dois elementos fundamentais pautavam a realização de uma sociedade justa e livre de iniqüidades: a inexistência da propriedade privada e a perseguição de interesses da coletividade em lugar de intersses individuais (MORE, 2012).

A partir desta obra, utopias passaram a fazer referência a realidades imaginadas, nas quais uma ordem social desejada opera sem fricções com interesses individuais ou realidades materiais. As utopias carregam consigo uma concepção de ordem perfeita que não poderia ser alcançada pela realidade presente. As descrições utópicas assentam-se sobre uma tabula rasa, um cenário completamente novo, livre das complexidades, conflitos e heterogeneidade da vida social. Se estabelecem, portanto, a partir de um ponto de partida "em branco, do qual desaparecem interesses divergentes, a aflição e a miséria encontradas no mundo real. Assim, utopias não propõem soluções para os problemas reais, elas iniciam e desenham sociedades perfeitas a partir de um olhar crítico aos ordenamentos sociais considerados inaceitáveis, destruíndo-os por completo em suas construções imaginárias.

De fato, as utopias parecem ter perdido seu lugar na imaginação política, em sua capacidade de resistência e questionamento das ordens sociais. Da parte de organismos de governança internacional e de governo nacionais, prevalecem orientações pela promoção de maior eficiência de órgãos de governo na condução do desenvolvimento. Este formato confirma o papel da burocracia estatal na manutenção da ordem e se orienta pelo aconselhamento de experts, sem promover, efetivamente, formatos de participação, envolvimento e questionamento por parte da sociedade. Em muitos casos, a direção da política a partir de conhecimentos especializados é apontada como um caminho certeiro, a orientar ações e imaginários sociais em direção a um mundo mais bem gerido e, 
em uma relação "de cima para baixo (top down), termina por estabelecer objetivos comuns de governo a sociedades distintas.

Há, por outro lado, a persistência do que identificamos como uma "grande utopia" que se difunde pelas sociedades em escala global, relacionada aos sistemas de trocas, circulação e gestão: a utopia de "fluxos ilimitados. Esta utopia consistiria no fim de limitações materiais ao livre fluxo de pessoas, bens e informações, e fundamentaria tentativas de organizar e governar as sociedades em escalas cada vez maiores. A realidade social é imaginada como descolada das amarras espaciais e livremente contectada; e as subjetividades e materialidades percebidas como não apresentando fricções ou impedimentos à livre circulação ${ }^{6}$.

A utopia dos fluxos ilimitados pode ser percebida como um objetivo último das modernas tecnologias de informação e comunicação, ao almejar fluxos ilimitados de bens e ideias, configurando elementos-chave para alcançar uma coletividade perfeitamente governável - não localizada, não situada, e livre de contextos. Promove, portanto, uma virtualização das relações, pelas quais todos estes elementos podem ser geridos por redes virtuais. A grande utopia do nosso tempo poderia ser portanto descrita

6 A omissão das várias infra-estruturas que apoiam e sustentam a circulação de capitais, pessoas, materiais e morais, e as várias ações e atores necessários para construir e manter in loco esse tipo de aspiração universal é precisamente uma utopia. Estudos sociais de infra-estruturas de informação mostram, por exemplo, que as dimensões aparentemente virtuais, atemporais, livres do espaço - como a Internet-, estão, na realidade pautadas em pessoas e no trabalho empreendido para construir e manter essas infra-estruturas funcionais (STAR; RUHLEDER, 1994; EDWARDS, 2003; BOWKER et al, 2009). A possibilidade de inverter analiticamente (BOWKER ; STAR 1999) tais infra-estruturas para ver como elas funcionam e o que elas envolvem, denotando processos de negociação necessários para mantê-las, chama a atenção para o presente, o material, o situado e incorporado nos bastidores da utopia «universal». 
como pautada em perspectivas universalizantes e objetivadoras do mundo social, na busca por superar as especificidades próprias à realidade, fundamentadas em processos de virtualização.

A política contemporânea parece, portanto, pautada por esta dualidade em relação às utopias: ao mesmo tempo em que rejeita o aspecto imaginado de sociedades almejadas, focando em mecanismos de governo orientados por organismos internacionais para a promoção de melhoras "efetivas" nas sociedades - na promoção do "desenvolvimento -, aparece imersa em imaginações universalizantes e virtualizantes desta realidade social, em que as trocas e relações são, de fato, retiradas de seu lugar, de suas amarras, e tornam-se, em algum sentido, imaginadas. Realidade e utopias são percebidas como elementos excludentes, mas encontram-se, de fato, profundamente unidos nas construções do mundo social.

Este ensaio busca renovar nossa atenção sobre as utopias, situando-as no tempo presente, nas práticas quotidianas, nos movimentos de reprodução ou de contestação social. Argumentamos que as utopias podem ser percebidas nas "práticas" a partir das quais se pensam e buscam soluções para os problemas sociais. Para tanto, partimos do conceito de heterotopia, elaborado por Foucault (2004), que apresenta uma perspectiva situada do pensamento utópico, e incorporamos a concepção dos imaginários sociotécnicos,desenvolvida por Sheila Jasanoff e Sang-Hyun Kim (2009) a fim de entender os desejos de reforma como uma característica das sociedades presentes. Com base nestes conceitos, promovese uma releitura sobre o reavivamento das utopias nas políticas contemporâneas.

Esta perspectiva conceitual nos permite introduzir casos específicos, que demonstram alternativas à perspectiva utópica de mundos virtuais e ausentes de fricção. Os casos retratam coletivos trabalhando em espaços e tempos situados, recuperando 
a importância dessas dimensões para suas vidas e articulando diferentes versões de ordenamentos sociais ou demostrando implicitamente a importância da interação entre significados e lugares. Os exemplos foram buscados em movimentos no Brasil (ocupação de escolas por estudantes em São Paulo), França (transformação do uso do espaço no aeroporto em Notre Dame des Landes), Suíça (novas formas de uso do espaço via habitações cooperativas) e nos Estados Unidos / China (reprodução de cidades ocidentais na China), pelos quais utopias foram criadas, transportadas e reformuladas. Discutimos estes exemplos a partir dos conceitos de heterotopias e imaginários sociotécnicos.

\section{I - Utopias situadas: o corpo como utopia subjetiva e "outros lugares"}

Os debates sobre utopias remetem à ideia de fuga, a uma perspectiva externa à realidade, onde a imaginação permite um mundo perfeito. Se tomamos a palavra utopia em seu sentido literal (em grego, "sem lugar"), o pensamento utópico nos direciona a uma rejeição do presente, confundindo nossas capacidades de perceber e transformar nossos próprios locais e situações. A abordagem proposta por Foucault, entretanto, apresenta uma perspectiva das utopias como ancoradas em seu lugares e contextos de formação.

De acordo com Foucault, todas as utopias têm sua origem na localidade e realidade originais: no corpo, nos lugares, nas sociedades em que vivemos; de onde decorre uma imbricação necessária entre utopia e seu lugar/situação de produção e da importância de voltar a essas condições. Foucault revela o corpo humano como o contexto local e material a partir do qual as utopias são concebidas. O corpo é descrito como a localização absoluta de todo indivíduo, de onde podemos ver, imaginar, sentir e interpretar a realidade. 
Neste sentido, o corpo é descrito como o local (a topia) implacável, à qual estamos permanentemente presos, fadados a conviver com suas imperfeições e defeitos, sentir através dele as feridas e angústias. Assim, para o sociólogo, a primeira utopia consiste em se libertar deste corpo, trocando-o por uma versão aperfeiçoada (FOUCAULT, 2009).

Nos trabalhos de Foucault, o espaço não é uma dimensão neutra e objetiva, mas algo que é criado, organizado e polarizado por tecnologias de poder. Em "Vigiar e punir", o espaço é retomado na análise das instituições modernas, como prisões, hospitais ou escolas, que são interpretadas como espaços de reprodução social e ascensão da sociedade disciplinar. Nestes espaços específicos, formas sociais são reproduzidas, ordenamentos são criados e reforçados (FOUCAULT, 1987).

Alguns anos antes, em uma conferência dedicada a "outros espaços", Foucault considerou o espaço como uma categoria analítica central, crucial para o que ele chamou de heterotopologia. O objeto deste conceito são os espaços alternativos (hetero-topias, outros espaços) criados pela sociedade, onde é possível produzir "uma espécie de contestação ao mesmo tempo mítica e real do espaço em que vivemos". Estes espaços alternativos, ou heterotopias, variam eminentemente de acordo com o tempo e a cultura. Assim, uma escola ou um quarto de motel consistem em heterotopias circunscritas, isoladas, onde atividades tais como a educação, o crescimento ou a relação sexual possam ocorrer fora de vista $^{7}(-$ FOUCAULT, 2009).

7 Como os Estudos Sociais de Ciência e Tecnologia têm mostrado ao longo de décadas, o laboratório é uma das mais poderosas heterotopias da modernidade. O laboratório é um local que se liga a todos os outros juntos, enquanto separando ao mesmo tempo suas atividiades de pesquisa. Em seu artigo «Give me 
O que interessa a Foucault no conceito de heterotopia é pensar a heterogeneidade dos processos sociais que ocorrem nos "outros espaços, a fim de propor critérios que permitam identificar as relações destes espaços com a sociedade.

\section{II - Lugares utópicos, espaços fechados}

A imaginação de utopias costuma trazer à mente espaços de vida envoltos em determinadas fronteiras, naturais ou artificiais, flutuando no espaço ou localizados em outro planeta. Nas conceituações clássicas de utopia, a dimensão espacial costuma aparecer contida: a utopia de Thomas More é constituida por uma ilha cercada por águas, dentro da qual um segundo círculo de água constrõe outra divisão entre vida em periferia e vida no centro (Imagem 1).

Quatrocentos anos depois, a ideia de utopia é atualizada, com o auxílio de tecnologias que refletem a chegada da Era Espacial. Em meados do século XX, alguns países competiam ativamente na conquista espacial, com o envio de veículos e humanos para o espaço orbital. Parte do apelo discursivo em conquistar o espaço era a idéia de vida em outros planetas e a possibilidade de habitá-los.

a laboratory and I will raise the world» Latour (1983) mostra como o laboratório de Pasteur foi construído tanto como um lugar que combina atores heterogêneos / actantes (por exemplo, exploração agrícola, carneiros, bactérias, agricultura francesa), enquanto sendo o único lugar onde é possível estabelecer o conhecimento científico, um "ponto de passagem obrigatório". De forma mais contundente, os laboratórios são descritos como lugares específicos onde os "fatos científicos " são produzidos. O recurso experimental parece ser um elemento essencial na heterotopia contemporânea. 
O apelo deste ideário se baseava nas experiências de guerra e na necessidade de ampliar horizontes e espaços habitáveis ${ }^{8}$.

De fato, a ideia de viajar e viver no espaço representou uma extensão do folclore tradicional norte-americano, como uma nação fundada por colonos em busca de expaandir suas fronteiras. Uma das principais instituições da Era Espacial, a Agência Espacial Norte-mernicana (National Aeronautics and Space Administration, NASA), incentivou a imaginação desta nova utopia. Uma imagem produzida por esta agência se baseia na tecnologia do plástico maleável, tecnologia inventada no inicio da Era Espacial. A "utopia proposta pela NASA era de uma comunidade totalmente fechada em órbita no espaço (Imagem 2).

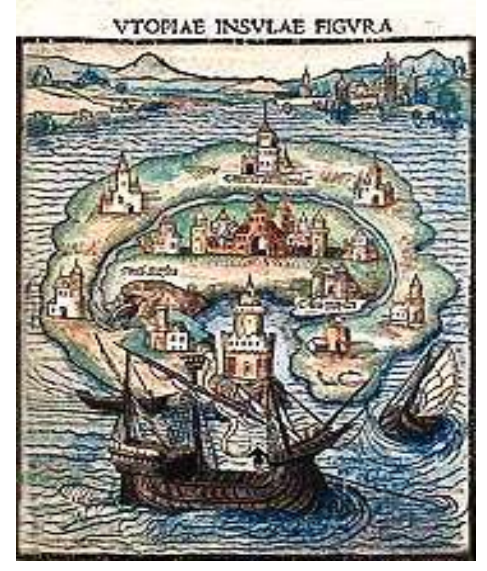

Imagem 1 - A utopia de More

8 Embora as utopias do espaço sideral não abordam especificamente quais cidadãos seriam bem-vindos, o período pós-Segunda Guerra Mundial forneceu um contexto histórico que fez qualquer visão de lugares harmoniosos e livres da guerra como uma visão desejável, um contraponto necessário à disputa do espaço através da guerra. 


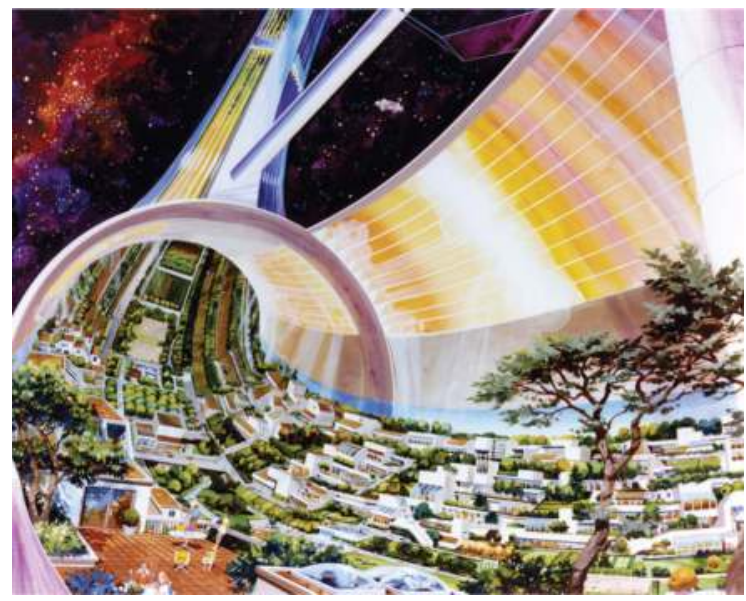

Imagem 2 - Colonia espacial da NASA ${ }^{9}$

Estas imagens de utopias representam espaços ideais, edifícios e ordens sociais, e transmitem valores e hábitos através de tecnologias de construção e paisagens (GAGLIARDI, 1990). Ao observar as duas representações acima, é possível identificar o predomínio de altos edifícios, em meio a uma paisagem com algumas representações da natureza. Cada imagem reflete as tecnologias de construção e arranjos típicos da época em que foram produzidas. As representações congregam aspectos do mundo natural e tecnológico combinados, reproduzindo ideias pautadas nas vivências existentes.

Estas representações levantam aspectos inclusivos e exclusivos da utopia. Os formuladores de utopias demarcam que tipos de

9 Fonte:http://settlement.arc.nasa.gov/75SummerStudy/able_of_Contents1. html; http://settlement.arc.nasa.gov/; http://www.nss.org/settlement/physicstoday.htm. 
natureza são incluídos (por exemplo, ambas as imagens representam parte da flora) e excluídos (por exemplo, na imagem 2 seres humanos precisam de um escudo entre si e espaço exterior, ao fim de criar uma atmosfera na qual possam respirar). É possível questionar: o que acontece com as pessoas? Quem habita estas utopias? As pessoas não são visíveis nessas representações. Em vez disso, constam seus domicílios imaginados, seus "espaços contidos, suas heterotopias, no âmbito das quais suas relações deveriam se desenvolver, distantes do espaço público.

Os próprios edifícios consistem em representações que indicam como as pessoas deveriam viver, em que tipo de ordem, e com que tipos de relações tecnológicas. Castelos, igrejas e habitações suburbanas levam à mente pessoas específicas e seus status socioeconômicos. Estes edifícios são contemporâneos à época em que as representações das utopias foram produzidas. Esta é uma indicação de como podemos identificar aspectos contemporâneos das utopias. Mesmo diante do desejo de escapar da realidade, utopias não são constituídas no vazio.

\section{III - Imaginários sociotécnicos}

O conceito de imaginários sociotécnicos, desenvolvido por Jasanoff e Kim (2009), e posteriormente elaborado por Jasanoff (2015), fornece um entendimento acerca das relações entre imaginações e realidade para compreender escolhas sociais a nível nacional ou comunitário. Inicialmente propostos para compreender como Estados realizam escolhas envolvendo ciência e tecnologia de acordo com suas preferências e visões culturais, o conceito também pode ser utilizado para analisar escolhas científicas e tecnológicas por arranjos comunitários e coletividades em geral. 
Os imaginários sociotécnicos são definidos como «formas coletivamente imaginadas de vida e ordem sociais, refletidas no projeto e realização de empreendimentos científicos e/ou tecnológicos específicos a uma nação” (JASANOFF; KIM, 2009, p.120). São, desta forma, um futuro imaginado por uma nação (ou coletividade) como desejado, atingível e preferível dentre outros futuros ou trajetórias, e envolvem escolhas socias, tecnológicas, dentre outras, que passa a ser perseguidas pelas políticas nacionais. Revelam, neste sentido, decisões sobre ordenamentos entre ciência, tecnologia, materialidade e sociedade.

Esses imaginários encontram-se inscritos nas culturas políticas e institucionais, e se relacionam a expectativas comuns na busca e perseguição do que é traçado como "melhor cenário futuro. Os imaginários sociotécnicos são construídos no presente, mas referem-se a futuros preferíveis, a serem perseguidos. Diferentes imaginários podem coexistir dentro de uma sociedade, proveniente de indivíduos, empresas, movimentos sociais ou outras partes da comunidade. No entanto, eles se tornam imaginários quando ganhar força ao longo do tempo, tornando-se perspectivas dominantes no seio das comunidades (JASANOFF, 2015).

O conceito de imaginários sociotécnicos nos permite compreender os caminhos que os projetos idealizados percorrem até suas realizações na esfera publica e social. Esta abordagem recusa uma perspectiva linear do desenvolvimento tecnológico e aponta para uma ampla gama de possíveis trajetórias tecnocientíficas, dirigidas por escolhas públicas e influenciadas de acordo com diferentes contextos e culturas. A imaginação é considerada como um importante recurso cultural que permite novas formas de gestão, para "projetar futuros objetivos positivos e procurar alcançá-los" (JASANOFF; KIM, 2009). 
A ênfase nos recursos imaginativos para a prossecução de um bem público expande abordagens tradicionais que se focadas em recursos materiais e organizacionais. Neste ensaio, argumentamos que é possível identificar semelhanças e potencialidades ao aproximar o quadro dos imaginários sociotécnicos da conceituação de heteropias por Foucault. Reconhecendo a importância da cultura, das estruturas, da materialidade e do conhecimento acumulado na construção de imaginários, os imaginários sociotécnicos trazem novos elementos a uma perspectiva que reconhece a importância dos lugares na reprodução da vida social - seja nos espaços públicos, seja nas heterotopias.

Os conceitos de imaginários sociotécnicos e de heterotopias apontam para a possibilidade de revisitar o mundo atual e resistir a estruturas consideradas opressivas. Isto irá ser discutido nos casos abaixo.

\section{IV - Quatro exemplos de utopias situadas}
A-Aeroporto Notre-Dame des Landes (NDDL): uma heterotopia de conflito

O projeto de construção de um aeroporto internacional nos arredores da pequena cidade de Notre-Dame des Landes (parte oeste da França) continua aparecendo nas manchetes dos principais jornais franceses.A história começou em 1963, quando o presidente De Gaulle decidiu construir um aeroporto internacional, a fim de descentralizar o tráfego do aeroporto de Paris. Rapidamente, o projeto foi objeto de intensa contestação, inicialmente pelos agricultores cujas terras estão incluídas na Zona de Desenvolvimento Específico (em francês, Zone dAménagement Differé, ZAD) e encontram-se ameaçadas pela construção do aeroporto. Na década 
de 70, o projeto foi temporariamente suspenso, principalmente por causa da crise do petróleo e de inúmeros protestos no local. O plano para NDDL foi reativado no início dos anos 2000 pelo governo socialista de Lionel Jospin. Quarenta anos após a sua criação, os argumentos a favor do projeto mudaram, orientando-se para a "necessidade" de desenvolver fluxos internacionais econômicos e humanos alinhados com o mundo globalizado.

Em 2008, depois de anos de resignificação dos argumentos e de procedimentos de consulta pública, o projeto foi declarado como utilidade pública. No entanto, isto marcou o início de uma grande oposição de agricultores e de movimentos sociais que denunciam o projeto como a negação de compromissos ambientais tomados anteriormente pelo governo francês, relacionados à destruição de uma área preservada da agricultura intensiva. Novos estudos de impacto ambiental foram lançados por empresas especializadas, que também experimentaram métodos gerenciais aplicados à biodiversidade (DAUGUET, 2015).

As inúmeras mobilizações, procedimentos e apelos à corte tornaram o caso de NDDL um dos mais importantes movimentos sociais dos últimos anos na França. O que é notável neste caso é a dimensão situada de contestação. Os opositores ocuparam o espaço inicialmente dedicado ao aeroporto e o rebatizaram como Zona A ser Defendida, mantendo o mesmo acrônimo (ZAD) do projeto de governo. Uma parte dos opositores passou a ocupar permanentemente a ZAD para impedir o início dos trabalhos de construção. A vida da comunidade organizada em torno da resistência ao projeto foi estabelecida e regularmente marcada por confrontos com as forças policiais.

A polissemia da sigla ZAD mostra como o caso do aeroporto NDDL representaum conflito entre dois modelos de apropriação espacial, construindo uma nova heterotopia. Esta heterotopia, 
resultante da relação conflituosa entre projetos distintos, resulta em que a zona não permaneça como espaço de produção agrícola, nem como aeroporto, mas seja transfromada em um espaço de resistência. A nova heterotopia pode ser lida como parte do conflito inerente às origens do pensamento utópico: um conflito sobre como se desejam organizar os espaços e nossas relações uns com os outros.

Por um lado, do ponto de vista governamental, a zona é concebida como um centro que reorganizaria parte do espaço econômico e social do noroeste francês. A construção do aeroporto colocaria a região no coração do Espaço Económico Europeu (EEE), enquanto racionalizaria os fluxos de passageiros fora da área de Paris. De acordo com o que temos descrito anteriormente, o aeroporto é um lugar performativo da ideia de livre circulação de bens e pessoas em um espaço aberto; ele é por excelência um não -lugar ${ }^{10}$ (AUGÉ, 1992). O caso NDDL também mostra a condição material desta utopia e a incapacidade de torná-la concreta a partir do nada. Há um espaço a ser desenvolvido, faixas de avião e estradas a serem construídas para organizar o território.

Por outro lado, a zona é imaginada como um baluarte a ser defendido, um lugar único a ser preservado. Parte do trabalho dos ativistas é tornar a área do aeroporto como única, destacando suas singularidades, humanas ou não-humanas. Ressalta-se, neste sentido, a necessidade de proteção de espécies locais contra o trítio, apresentada por ambientalistas. O ZAD é também o lugar a partir do qual é possível imaginar outros futuros possíveis longe do futuro "necessário" de uma globalização dolorosa. Assim, muitos

10 Se um lugar pode ser definido como a identidade, relacional e histórica, um espaço que não pode ser definido em termos identitários ou como relacional, nem como histórico definiria um não-lugar (AUGÉ, 1992, p.100). 
slogans não só exigem o abandono do projeto do aeroporto, mas também evocam uma rejeição do "mundo" que acompanha a sua construção. O acrônimo Zona A ser Defendida foi então recuperado por outros grupos na França para se opor a projetos de desenvolvimento, que ocupam territórios da mesma forma.

Em confronto com a contestação e as reivindicações dos ativistas, o principal desafio dos estudos de avaliação do impacto ambiental não é mais de negar os danos ambientais resultantes da construção do aeroporto, mas de demonstrar demonstrando como esses danos podem ser compensados. Em outras palavras, trata-se de transformar " $a$ " região em "uma" região qualquer, comparável a qualquer outra, em qualquer lugar. A comensurabilidade dos territórios com base em argumentos científicos é um elemento-chave da compensação ecológica, uma vez que elimina a especificidade dos lugares e permite reorganizar o espaço que perde assim suas especificidades.

Resumindo, o caso do aeroporto NDDL mostra que podem existir contradições radicais entre heterotopias, mas especialmente, o caso demostra a importância de ocupar o espaço para tornar permanente uma tal heterotopia.Além disso, o caso levanta a importância do conhecimento, que pode ser situado ou extraído de seu local para sustentar pretenções ao universal (HARAWAY, 1988) como um recurso para legitimar ações, reunir pessoas, e tornar as heterotopias credíveis. Finalmente, gostaríamos de insistir na dualidade do conceito de "experimento" que poderia ser visto em seu sentido analítico, ou seja, uma forma de testar um novo dispositivo para organizar o espaço, enquanto integra as críticas ecológicas, mas também em um sentido mais prescritivo, como um modo de ação para defender e concretizar heterotopias minoritárias. 


\section{B - Reorganização e Resistência em São Paulo}

Em setembro de 2015, o governo do Estado de São Paulo anunciou uma reorganização do seu sistema de ensino público, que se iniciaria no ano seguinte, levando ao encerramento de 94 escolas de funcionamento e o deslocamento de mais de 311 mil alunos $^{11}$ para outras escolas. Este anúncio desencadeou um movimento de resistência de grandes proporções, amplamente coberto pela mídia nacional. O objetivo declarado da política de reorganização escolar era implementar um novo modelo, baseado em escolas divididas de acordo com a "ciclos" - atribuindo diferentes idades e estágios de ensino em diferentes edificios. Famílias, conselhos escolares e os alunos não haviam sido consultados ou previamente comunicados da decisão.

Insatisfeitos com a decisão, considerada pouco transparente e imposta a partir "de cima, sem participação ou consulta de alunos, famílias e funcionários afetados, iniciou-se um movimento de ocupação das escolas por todo o Estado, realizado pelos próprios alunos. A mobilização estudantil congregou demandas diversas e foi principalmente pautada pela objeção a um histórico de baixa atenção do governo em relação à educação pública. Dentre as críticas à proposta, também constava a desconfiança dos reais motivos do fechamento das escolas, constantemente acusado de ser conduzido por interesses privados, voltados à liberação de espaços urbanos valorizados para disponibilização a outras finalidades. A

11 Fonte: "Reorganização atinge 311 mil alunos e 'disponibiliza' 94 escolas de SP”. Disponível em: <http://g1.globo.com/sao-paulo/noticia/2015/10/reorganizacao-escolar-em-sp-tem-94-escolas-que-serao-disponibilizadas.html>. Acesso em: Mar. 2016. 
exigência fundamental era o cancelamento do plano de reorganização e uma maior atenção ao sistema de ensino.

Inspirados pelo movimento em São Paulo, alunos do Estado de Goiás também iniciaram movimentos de ocupação escolar, chamando a atenção para grande insatisfação com as políticas educacionais. Ao final do ano de 2015, mais de 200 escolas haviam sido ocupadas no Estado de São Paulo por alunos de diferentes idades, e vários protestos haviam sido realizados nas ruas da capital do estado. O movimento chamou a atenção nacional pela sua longa duração, com ocupações que ultrapassaram dois meses de duração; pela participação maciça de estudantes e, sobretudo, pela faixa estária dos manifestantes, adolescentes e pré-adolescentes.

A resistência evidenciou de maneira vívida uma profunda disjunção entre políticas e processos de tomada de decisão do Estado e as demandas, anseios e realidades da população usuária dos serviços públicos. A posição do governo durante grande parte do período das ocupações foi marcada pela intransigência em reconsiderar a política, e pela tentativa de reaver os espaços por meio judiciais, sem apresentar abertura ou espaços de debate.

Em 29 de novembro, uma reunião do Departamento de Educação foi gravada e seu conteúdo foi divulgado à imprensa. No áudio, o Secretário de Educação paulista, em meio a cerca de 40 diretores de escolas públicas, orientava uma ação para a quebra da resistência. $\mathrm{O}$ representante de governo tomou como base os meios judiciais em curso para a implementação da reorganização escolar. Além disso, demonstrava pouco reconhecimento das demandas dos alunos, tratando a situação como um "estado de guerra". Na visão do Secretário, era necessário desmoralizar os grupos contrários à reorganização, respondendo às ocupações com "práticas de guerrilha”, incluindo a fotografia de placas de veículos nos arredores das escolas ocupadas e ações contra o Sindicato dos Professores. 
Após a divulgação do conteúdo da reunião, em 04 de dezembro, o governador do Estado, Geraldo Alckmin, fez um pronunciamento adiando a reorganização, com a promessa de aprofundar o diálogo com os estudantes, famílias e funcionários. A declaração marcou o início da desocupação das escolas edifícios (SANTIAGO, 2015).

Embora não seja possível afirmar, até o presente momento, que a política educacional tenha efetivamente cumprido a promessa de maior inclusão e diálogo com os usuários afetados, as ocupações demostraram a importância do espaço, de seu uso e de imaginários conflitantes no resultado final de um projeto político. No caso, o projeto de reorganização escolar proposto pelo governo não incluiu as perspectivas dos alunos, principais usuários do sistema educacional.

Tanto como no exemplo de NDDL, o uso dos espaços foi fundamental para a afirmação da resistência, e na promoção de um imaginário de ocupação do espaço escolar distinto daquele encampado pelo governo. As ocupações representaram uma releitura do espaço escolar, que se transformou em espaço de resistência, tanto quanto um sentimento de apropriação e de pertencimento àquele espaço. Os alunos se alternavam em turnos, garantindo uma presença constante dentro das ecolas. No interior dos edificios, eram realizadas diferentes atividades que sustentavam a ocupação - como produção das refeições - e promoviam o debate sobre educação pública, o papel da escola, entre outros temas correlatos. Algumas ocupações foram visitadas por artistas bastante conhecidos, como músicos e cartunistas, que apresentavam seu apoio ao movimento, participando dos debates e fazendo apresentações. Cabe ressaltar que a mídia alternativa teve um papel predominante ao divulgar as atividades internas, as posições dos estudantes, o apoio de setores artísticos e intelectuais, que não eram reproduzidos pela grande mídia. 
Neste sentido, os movimentos de ocupação, tanto em São Paulo como em NDDL, podem ser considerados como uma forma de apropriação alternativa de um espaço social, considerado por Foucault como heterotópico. Para o autor, as heterotopias são lugares fisicos excluídos dos demais espaços culturais ordinários da sociedade, mas que reproduzem ou contêm as diferenças da norma social, o "específico". Neste sentido, possuem uma relação de sustentação do modelo social vigente, na medida em que contêm, dentro de si, os desvios da norma ordinária. É o caso das prisões, casa de repouso, cemitérios, entre outros. Para o autor, "a heterotopia tem o poder de justapor em um único espaço real vários espaços", que são incompativeis entre si (FOUCAULT, 1967). Seguindo essa definição, as escolas também podem ser descritas como heterotopias, na medida em que são espaços contidos de formação, educação, adequação à norma social, e, ainda, de planificação da sociedade, na medida em que estabelecem um conteúdo comum, uma narrativa, aos alunos.

As escolas possuem, na sociedade, um lugar e simbologia específicos. As ocupações promoveram uma leitura e utilização alternativa deste espaço. Tradicionalmente, a escola desempenha o papel de espaço contido com a finalidade de educar as crianças dentro dos limites de uma política de educação formal, orientada pelo Estado. As ocupações transformam esse espaço em uma arena de resistência, apontando para diferentes leituras das relações entre Estado e estudantes. O espaço destinado ao ensino foi apropriado por seus usuários como um lugar para a difusão de reivindicações, onde seus ocupantes formais - estudantes - demandam ser levados em consideração e inseridos nos processos de tomada de decisão.

O movimento também apontou para a inadequação de um planejamento utópico de macroestruturas com base em decisões de cima para baixo, justificadas por argumentos técnicos pouco 
publicizados ou debatidos. O plano de reorganização com base na relação custo-eficiência, imaginando que estudantes e funcionários são facilmente deslocáveis -sem as fricções próprias da subjetividade, da sensação de pertencimento, ou mesmo das realidades individuais de alunos que residem espaços afastados das novas escolas às quais foram destinados-, foi contestado por diversos constrangimentos reais, apresentados pelo espaço e pela sociedade. Estes elementos dependem da real vivência e experiência no espaço e nas relações para serem considerados. Neste sentido, a resistência à política escolar em São Paulo é um exemplo de conflito sociopolítico, tendo como principais elementos o espaço, a comunidade, os laços sociais, como indissociáveis uns dos outros.

\section{C - Cooperativas de habitação, direitos de propriedade e (auto) definições dos sujeitos na Suiça}

A baía do Lago de Genebra, na Suíça, é um lugar de especulação imobiliária há mais de vinte anos. A possibilidade de viver em uma casa, neste espaço tranquilo e de belas paisagens naturais tornou-se um privilégio caro, imerso em uma rede de propriedades privadas composta por regras fiscais, jurídicas e econômicas. Formas de moradia alternativas, incluindo assentamentos e moradias irregulares, às margens da propriedades privadas foram gradualmente sendo coibidas pelas autoridades, e abrindo espaço para a especulação e a construção de edificios luxuosos por grupos imobiliairos. A disputa pela ocupação do espaço ocorre com a participação das autoridades no endurecimento progressivo contra as violações dos direitos de propriedade. Neste contexto, alguns grupos se organizaram em torno de alternativas que lhes permitissem, dentro do quadro jurídico, garantir um espaço de vida acessível 
economicamente, mas também pautado por outros direitos que incluíram questões de pertencimento e apropriação do espaço.

Kamila faz parte de um grupo que se organizou em uma habitação cooperativa (HC) desde 2012 para comprar uma propriedade abandonada na beira do lago, listado como patrimônio histórico da região. Composto por vinte e quatro pessoas, este grupo é parcialmente baseado no que Kamila descreve como uma "utopia em comum". Esta utopia - um quadro de valores e crenças sobre como a coletividade deveria ser gerida - sustentou as regras do trabalho de restauração do edifício e a sua distribuíção entre os membros, mas também o uso e a repartição dos espaços de moradia na casa. A renovação do edifício está programada para oferecer duas cozinhas compartilhadas, geladeiras comuns, máquinas de lavar coletivas, uma biblioteca e um salão comum. Há também um plano para uma horta que será cultivada por todos.

As cooperativas de habitação suíças geralmente têm uma administração separada para os membros não terem de se preocupar com a manutenção e administração das tarefas. Essas tarefas são geralmente confiadas a uma empresa especializada. O projeto ao qual pertence Kamila é baseado em uma outra visão da propriedade residencial. Na cooperativa, o espaço comum - o edificio, o bairro - é gerenciado por aqueles que ocupam-no diretamente, sem a intermediação de representantes ou terceiros. Neste sentido, a cooperativa colocada em jogo pelo grupo inverte e questiona, especialmente nas cidades, a ocupação do espaço por seus moradores. Quais são as regras não escritas aos quais os moradores das cidades modernas aderem e que reproduzem diariamente para que seus movimentos se mantenham fluidos e seus encontros discretos? Como se organizam para compartilhar espaços sem se conhecer um ao outro? Kamila diz que a utopia em comum apoiou os membros durante a fase difícil das reformas da casa. $\mathrm{Na}$ frente de cada dificuldade 
ou problema, a utopia ajudou a reforçar as tropas e restaurar a vontade de trabalhar, proporcionando uma meta coletiva pela qual os problemas peculiares poderiam ser relativizados e/ou serviria como um compasso para orientar soluções. Ela explica que o grupo se distinguiu com este ideal de convivência para seu projeto de habitação, em oposição a uma perspectiva individualista. Foi este ideal que reanimou a vontade de continuar, apesar dos importantes problemas legais ou financeiros que encontraram. Esta foi a marca do grupo enquanto o projeto se desdobrava, ter uma visão específica de como eles queriam viver juntos, como uma forma ideal de organização, melhor do que as possibilidades oferecidas em espaços coletivos tradicionais. No entanto, se as reformas trouxeram a sua parte de problemas, esta mesma organização do trabalho e da distribuição dos espaços gradualmente minaram a coesão do grupo. Os interesses de cada um, de acordo com Kamila, voltaram a pesar na balança. $\mathrm{Na}$ frente de injustiças sentidas por alguns, a utopia da comunidade não se mostrou suficiente. Longas discussões de regras e explicações de definições implícitas do que seria a igualdade e como deveria ser feita a coexistência foram desenvolvidas. Reescreveu-se progressivamente o projeto coletivo de forma a torná-lo adequado, na percepção de todos, às novas perguntas e incompatibilidades de pontos de vista ou de definições. Os participantes perderam um pouco de seus desejos utópicos no processo, para adequarem-se ao que foi sentido como a "realidade" da vida cotidiana e sua necessidade de organização material, como descreve Kamila. Uma vez a crise ultrapassada, ela sente a possibilidade de emergência de uma utopia coletiva renovada .

Incorporar uma utopia de comunidade para além do discurso mostrou sere um longo processo, permeado por negociações e conflitos. A proposição de um espaço alternativo aos modos 
contemporâneos de habitação não é um processo óbvio ou facilmente gerenciado. Exige uma reflexão profunda e um trabalho de legitimação adicional, pois não faz parte dos tradicionais circuitos de locação e venda de moradia que predominam nas relações de propriedade e de habitação. Envolve não apenas elementos ligados à situação de cada participante, mas também depende de novas formas de interação, às quais os participantes não estão acostumados. Nesta situação, não existem regras pré-estabelecidas às quais possam recorrer para justificar suas ações; é preciso constantemente reformular argumentos de forma a convencer o grupo para a tomada de decisões corriqueiras e cotidianas.

A cooperativa representa um espaço de novas interações e, ao mesmo tempo, inscreve-se materialmente entre apartamentos individuais e as casas de familia nos formatos de propriedade tradicionais. Neste sentido, a HC funciona plenamente como uma heterotopia foucaultiana interogando as formas de vida que as residências tradicionais oferecem. A cooperativa permanece registrada em um espaço específico que circunscreve o lugar no qual ela pode implantar a sua utopia da vida em comunidade. Esta utopia, por sua vez, é transmitida e atualizada em diferentes espaços, para ser incorporada sob formas específicas e localizadas. A cooperativa ainda está listada em (e precisando de) todo o sistema fiscal, inscrita dentro das redes jurídicas e econômicas que o grupo procura respeitar para poder continuar com o projeto, ligada à região em que a casa está localizada. Seus habitantes permanecem sujeitos às regras e normas que ali se aplicam. No entanto, a cooperativa reflete essas regras e se constrói sobre os vácuos existentes nas legislações e normas sobre o uso do espaço, conferindo-lhes uma interpretação própria.

A cooperativa propõe um desafio à reprodução das tradicionais regras de espaço e habitação, geralmente pautadas em moradias 
individuais e familiares. Este desafio abre um espaço de contestação a partir do qual as regras e suas consequências podem ser observadas e interrogadas, na realidade concreta, material e presente. Kamila contou as dificuldades para que o projeto se adequasse aos regimentos e leis. A posição da cooperativa dentro do quadro legal teve de ser explicada muitas vezes a funcionários do estado. As suas interpretações entraram às vezes em conflito com as interpretações tradicionais, e eles tiveram que se ajustar e buscar meios de se legitimar para garantir o cumprimento de suas demandas.

A cooperativa oferece um espelho para os direitos de propriedade em que esses direitos são ligeiramente deformados, de acordo com os vácuos legais que regulam a ocupação do espaço. Também configuram um espelho nas organizações e reorganizações de formas de habitação, que pode oferecer outro reflexo através do qual podemos nos ver, onde a antiga dicotomia "individual/coletivo" se reorganiza na prática e é constantemente testada no cotidiano de seus membros. Se o auto-conhecimento e outros edificios nas nossas cidades podem aparecer como relacionados à formação de um sujeito individual-singularizado que estabelece relações mais ou menos estreitas com os seus vizinhos, o cooperativa propõe novas formas de relação entre áreas comuns e definições individuais.

\section{D-Novas fronteiras no século 21 na China}

Em 2015, um artigo no New York Times (JACOBS, 2015) nos informa que um imaginário utópico foi construído na China e aprovado por seus habitantes. O artigo chamado "A New Frontier for the American West in the Far East", descreve uma comunidade construída para "imitar a vida no oeste americano". Seguindo a descrição, entendemos que o oeste americano tomado como modelo para esta comunidade é o do século XVIII não aquele do 
século XXI. O novo farwest se localiza nos arredores de Pequim e é um exemplo de construção utilizando uma imaginação "utópica" como suporte para suas construções materiais e discursivas. Esta imaginação utópica é caracterizada pelo uso de imagens e imaginações sobre uma realidade alternativa, distante, e por uma interpretação particular da vida no oeste americano do passado. Este imaginário se pauta, em grande medida, por leituras e obras ficcionais do "Velho Oeste" (DELORIA, 1969).

Jackson Hole, na China leva o nome de Jackson Hole, Wyoming (WY), um vale no qual a cidade de Jackson está localizado no Estados Unidos. Jackson, WY tem uma população de cerca de dez mil pessoas e atrai turistas procurando paisagens rurais e atividades ao ar livre como caça, pesca, rafting, esqui e caminhadas. Em Jackson Hole na China, não se trata de um vale ou cidade, mas de um conjunto habitacional, para o qual moradores são atraídos por grandes casas rurais, em uma área com poucas outras referências ou relações com a estética e história do oeste americano. Aprendemos com Jacobs:

Durante a última década, mais de mil famílias se instalaram em casas de armação da madeira com quintais requintados, situadas em ruas com nomes tipo Aspen, Moose e Route 66. Aos domingos, alguns rezam em uma igreja situada na praça da cidade, equipada com cowboys de bronze e uma vitrola gigante arrancando água (JACOBS, 2015).

$\mathrm{O}$ artigo inclui uma imagem de um residente, o Sr. Qin, sentado à sua janela. Por trás dele vemos paredes de madeira escura e uma lareira de pedra. A rúbrica inclui uma citação na qual o Sr. Qin explica: "Os Estados Unidos representam o deserto e a liberdade, mas também grandes casas”. O tamanho da casa não é pouca 
coisa, porque Jackson Hole na China é uma comunidade de luxo que requer riqueza para poder entrar. Alguns de seus habitantes residem apenas nos fins de semana, enquanto outros moram na cidade o ano todo. Outra foto no artigo mostra o exterior da casa, uma mansão de pedra de vários andares.

O FarWest se tornou um mito exatamente da forma que o Sr. Qin o descreve. Depois da Segunda Guerra Mundial, o arquiteto americano de parques de diversões Walt Disney incluiu noções similares do oeste americano em um do seus parques chamado de "Frontierland ". "Frontierismo" refere-se à ocupação do oeste americano pelas populações que formaram os primeiros territórios na costa leste, em propriedades registradas por documentos legais. Esta versão do oeste americano exige o esquecimento do fato de que essas áreas já eram habitadas por tribos indígenas, com códigos sociais, costumes e imaginações que moldaram suas relações com a terra e suas formas de construir estruturas de habitação.

O farewest chinês inclui interações sociais prescritas sob a forma de eventos planejados para a comunidade. “... os residentes gostam de falar sobre o que eles chamam de abertura e calor de inspiração americana de Jackson Hole. Os desconhecidos se saúdam uns aos outros enquanto passeiam ao longo das ruas e referem-se uns aos outros por apelidos carinhosos como "Vanilla", "Little Lion" e "Old Hooligan." Um morador atribui essa simpatia ao caráter norte-americano destas construções, "a cidade definitivamente não é como outros lugares na China, diz ele. Nas cidades chinesas, você pode viver em um lugar por anos e nunca conhecer as pessoas que moram do outro lado da sua parede".

Há grupos de passatempo chamados "tribos de coleta de sonho", uma apropriação dos costumes de tribos indígenas, alinhada com o fronteirismo americano, como se a participação em um grupo de passatempo fosse semelhante à adesão tribal. Para os 
índios americanos, o velho oeste foi um período de conflito por terra, por legibilidade, por cultura e vida. Diabolizadas e caçadas, suas populações foram removidas, abrindo o caminho para uma visão do oeste como um espaço selvagem e desabitado.

De acordo com Kashani-Sabet (2000), a principal fonte de ficções sobre o farwest, narrativa que confere bases ao nacionalismo norte-americano, são os conflitos em torno das terras. Um lugar não é capaz de revelar que grupos podem ocupá-lo livremente, sem a ameação de remoção por outro grupo que contesta sua legitimidade. Em vez disso, as pessoas inventam formas de determinar quem tem o direito de ocupação e se utilizam de tecnologias e elementos concretos para competir por este espaço. A narrativa do farwest continua a fluir mesmo nos EUA, onde o Velho Oeste já perdeu suas características retratadas por filmes e obras ficcionais - para muitos, estas características nunca existiram de fato. $\mathrm{Na}$ verdade, a narrativa do Velho Oeste requer a crença que uma terra que não for habitada pelos nossos próprios compatriotas, sendo uma terra desabitada, uma terra de ninguém.

$\mathrm{Na}$ China, quem possui os recursos para viver no "sonho" de Jackson Hole? Quem é excluído deste espaço? Que consequências são esperadas para aqueles que romperem seus limites? O artigo descreve que os primeiros habitantes de Jackson Hole chegaram de Audi e Land Rover, com as malas cheias de vinho francês. A descrição destaca os recursos financeiros e sociais suportando o crescimento desta utopia. É um ambiente remoto com uma população selecionada apoiando a construção de infraestruturas -habitação, escolas, entretenimento - à imagem de uma sociedade ideal, de um imaginário de vida ocidental altamente desejado.

Olhando para a utopia de Jackson Hole na China através do quadro dos imaginários sociotécnicos, é possível perceber a presença de novas utopias reproduzindo uma versão da história 
que ignora conflitos e abusos de poder, e é substituída por uma abundância particular para uma população escolhida. Para que os "outros espaços" sejam mais do que uma reprodução imaginada do outro, precisamos examinar criticamente as crenças coletivas que constrõem os espaços utópicos, e quais crenças e grupos encontram espaço de resistência e luta por novas utopias.

\section{Conclusão}

Neste artigo, retomamos o aspecto situado das utopias, tanto quanto a necessidade de considerar relações sociais e espaciais na conformação de imaginários coletivos orientados a um "futuro desejado". As utopias remetem à resistência, à luta, à transformação social. Entretanto, elas são diferentemente imaginadas, de acordo com materialidades, contextos, interesses, identidades, sentimento de pertencimento e de legitimidade em relação à ocupação dos espaços. As utopias são perseguidas por diferentes grupos sociais, na tentativa de implementar no presente, imaginações que não tem (ainda) seu lugar - imaginações utópicas.

Buscamos ressaltar, a partir das perspectivas de Foucault e de Jasanoff e Kim, a importância de reconhecer o espaço original na conceituação das novas utopias. Da mesma forma, discordamos de uma visão de que, em algum momento, as utopias perderam seu espaço. Utopias, como formas imaginadas e coletivamente perseguidas, permanecem vivas e atuando nos usos e conformações dos espaços, vividos ou imaginados.

A discussão de imaginários sociotécnicos traz à luz a necessidade de consideração de elementos materiais, valores e sistemas sociotécnicos, na produção e reprodução de opções de vida social. Ao trazer imaginários sociotécnicas e heterotopias em conjunto para analisar os casos diferentes, propomos que esses fundamentos 
teóricos são complementares para a divulgação de elementos presentes de pensamento e ação utópica. Eles oferecem pistas importantes sobre como heterotopias podem trabalhar para oferecer as visões que embasam as transformações sociais em grupos que compartilham uma identidade comum e espacial: sejam eles ocupantes em uma ZAD, alunos e suas escolas, moradores e suas habitações cooperativas, chineses abastados e seu refúgio americano. Nestes exemplos, há uma reprodução das fronteiras da coletividade e uma constante redefinição de suas relações, algumas vezes contrapondo-se às associações homem/espaço/sociedade mais tradicionais.

Um objetivo central do ensaio foi abordar a noção de espaço enquanto "espaço experimental", no qual diferentes ações são empreendidas e testadas na prática. A abordagem proposta permitiu testar diferente versões da heterotopia como conceito de trabalho, orientado à ação. Chamamos a atenção para exemplos de resistência em curso, que muitas vezes ocorrem à margem dos espaços considerados centrais na reprodução social - governos, cortes, organizações de governança, grandes empresas, entre outros. Assim, selecionaram-se exemplos de luta, sem que se recorresse à utopia enquanto mundo radicalmente distinto e dissociado da realidade.

Ao buscar casos de utopia no cotidiano, faz-se necessário apontar para a consideração das contingências dos locais, significações, materialidades e pessoas envolvidos nas disputas por transformação do espaço. Em todos os casos, há uma infra-estrutura superior - legal, organizacional, política - com a qual as reconfigurações necessitam lutar ou negociar.

O caso do aeroporto NDDL ilustra a possível justaposição de utopias diferentes e a importância da interação e ocupação do espaço na formação e estabilização de heterotopia. Como tal, heterotopia não são espaços contidos independentes, mas encontram-se 
imersos em disputas pela legitimidade e garantia de um futuro alternativo desejado coletivamente. Ele também mostra como a ocupação consiste em um recurso essencial para concretizar uma heterotopia minoria. O movimento de ocupação escolar em São Paulo também demonstrou a capacidade de imaginar e resistir frente a uma cultura de gestão muitas vezes repressiva e justificada por decisões tecnocráticas. Como em Notre-Dame de Landes, o modelo de ocupação foi baseada em um espaço específico e um imaginário compartilhado sobre a forma de ocupação.

O caso do condomínio de luxo na China e as habitações comunitárias na Suíça também apresentam formas específicas e compartilhadas de imaginação que rompem com os formatos sociotécnicos de moradia tradicionalmente estabelecidos. A utopia, nestes exemplos, é demarcada pela capacidade de reproduzir uma versão específica do frontierismo americano, tanto quanto de garantir um modelo alternativo de moradia, cooperativo.

A perspectiva situada da utopia, retomando o lugar foucaultiano ao qual estamos presos, juntamente com a capacidade de imaginar diferentes destinos daqueles que são impostos, levantados pela perspectiva dos imaginários coletivos, foram fundamentais para mostrar como uma utopia estão presentes, sendo constantemente revividas e reproduzidas. Demos atenção aos detalhes e realizações práticas de visões alternativas, mostrando o seu funcionamento e peculiaridades, e insistimos nas ligações identitárias e reproduzidas coletivamente em busca de cada utopia.

\section{Referências}

AUGÉ, M. Des lieux aux non-lieux. Non-Lieux. Introduction à une anthropologie da surmodernité. Paris : Seuil, 1992. 
BOWKER ,G..; BAKER, K.; MILLERAND, F. et al. Toward Information Infrastructure Studies: Ways of Knowing in a Networked Environment. In: Hunsinger, Jeremy; Klastrup, Lisbeth; Allen, Matthew (éds), International Handbook of Internet Research. Dordrecht: Springer: Netherlands, p.97-117, 2009.

BOWKER, G..; STAR, S.L. Sorting things out: classification and its consequences. Cambridge Mass.: The MIT Press, 1999. (Inside technology).

DAUGUET, B. Biodiversity offsetting as a commodification process: a French case study as a concrete example. Biological Conservation, n.192, p.533-540. 2015.

DELORIA, V. Custer Died for Your Sins: An Indian Manifesto. University of Oklahoma Press, 1969.

DEUS, L. Entenda a evolução das ocupações de escolas em São Paulo. Revista Educação. Retrieved from: <http:// revistaeducacao.com.br/textos/0/entenda-a-evolucao-das-ocupacoes-de-escolas-em-sao-paulo-366953-1.asp. > Acesso em: 18 dec.2015.

EDWARDS, P. N. Infrastructure and Modernity: Force. Time, and Social Organization in the History of Sociotechnical Systems. In: MISA, T. J.; BREY, P.; FEENBERG,, A. (Eds.). Modernity and Technology. Cambridge Mass: MIT Press, p.185-226, 2003.

FOUCAULT, M. Vigiar e punir. Petrópolis:Vozes, 1987.

FOUCAULT, M. Le corps utopique, les hétérotopies. Paris:

Nouvelles Editions Lignes, 2009. 
GAGLIARDI, P. Symbols and Artifacts:Views of the Corporate Landscape. Walter de Gruyter, 1990.

HARAWAY, D., D. Situated knowledges: The science question in feminism and the privilege of partial perspective. Feminist Studies, v.14, n.3, p.575-599, 1988.

JACOBS, A. Living a Frontier Dream on the Outskirts of China's Capital. The New York Times. Retrieved from: < http://www. nytimes.com/2015/12/09/world/asia/a-new-frontier-for-the-american-west-in-the-far-east.html>. Acesso em: 8 dec. 2015.

JASANOFF, S.; KIM, S.-H. Containing the Atom: Sociotechnical Imaginaries and Nuclear Power in the United States and South Korea. Minerva, n.47, p.119-146, 2009.

JASANOFF, S.; KIM, S.-H. (Eds.). Dreamscapes. University of Chicago Press, 2015.

KASHANI-SABET, F. Frontier Fictions. Princeton, NJ: Princeton University Press, 2000.

MORE,T. Utopia. Tradução de Dominic Baker-Smith. E-book: Peguin classics, 2012.

RESENDE, P. Estudantes ocupam mais escolas em ato contra OSs na Educação, em GO. G1.com. Retrieved from: < http:// g1.globo.com/goias/noticia/2015/12/estudantes-ocupam-mais-escolas-em-ato-contra-oss-na-educacao-em-go.html $>$. Acesso em: 14 dec.2015. 
SANTIAGO, T. Alckmin oficializa revogação da reorganização internacional em São Paulo. G1.com. Retrieved from: < http://g1.globo.com/sao-paulo/escolas-ocupadas/noticia/2015/12/ alckmin-oficializa-revogacao-da-reorganizacao-escolar-em-sao -paulo.html.> Acesso em: 5 dec. 2015.

STAR, S.L.; RUHLEDER, K. Steps Towards An Ecology Of Infrastructure: Complex Problems. In Design And Access For LargeScale Collaborative Systems, In: Proceedings OfThe 1994 ACM Conference On Computer Supported Cooperative Work, ACM, p.253-264. 1994. 


\title{
O BUEN VIVIR: UMA OPORTUNIDADE DE IMAGINAR OUTRO MUNDO ${ }^{1}$
}

Alberto Acosta ${ }^{2}$

\begin{abstract}
"Veja você, senhor Nicetas - disse Baudolino -, quando não estava preso às tentações deste mundo, passava minhas noites a imaginar outros mundos. Um pouco com a ajuda do vinho e um pouco com a do mel. Não há nada pior que imaginar outros mundos para esquecer o quão doloroso é o mundo em que vivemos. Pelo menos assim eu pensava, então. Contudo eu não havia entendido ainda que, ao imaginar outros mundos, se acaba mudando também este."
\end{abstract}

Umberto Eco

1 Texto publicado, originalmente, na coletânea Um Campeão Visto de Perto - Uma Análise do Modelo de Desenvolvimento Brasileiro, Editado pela Heinrich Böll Foundation, na Série Democracia, em 2012. Disponível em: https://br.boell.org/sites/default/files/democracia_inside_a_champion_port_ final.pdf

2 Economista equatoriano graduado pela Universidade de Colônia, Alemanha. É professor da Faculdade Latino-americana de Ciências Sociais (FLACSOEquador) e professor visitante de universidades dentro e fora do Equador. Atua como assessor de movimentos sociais e consultor internacional. É autor de numerosas publicações sobre temas relacionados ao desenvolvimento e Buen Vivir, economia, petróleo, energia, dívida externa, migração, mineração e direitos da natureza. 


\section{O desenvolvimento, um fantasma inalcançável}

Desde meados do século XX, um fantasma percorre o mundo... Este fantasma é o desenvolvimento. E embora a maioria das pessoas, certamente, não acredite em fantasmas, pelo menos em algum momento acreditou no "desenvolvimento", se deixou influenciar pelo "desenvolvimento", perseguiu o "desenvolvimento", trabalhou pelo "desenvolvimento", viveu do "desenvolvimento"... E é muito provável que siga fazendo isso ainda hoje.

Sem negar a validade da busca ancestral pela satisfação das necessidades dos seres humanos, existente há muito tempo, o desenvolvimento como proposta global se institucionalizou em 20 de janeiro de 1949. Nesta época, o presidente dos Estados Unidos, Harry Truman, no "quarto ponto" de seu discurso perante o Congresso, definiu a maior parte do mundo como sendo "áreas subdesenvolvidas". E anunciou que todas as sociedades teriam que perseguir uma só meta: "o desenvolvimento".

Esta metáfora tirada da vida natural adquiriu um vigor inusitado. Tornou-se uma meta a ser alcançada por toda a humanidade. Então, no início da Guerra Fria, com o discurso do "desenvolvimento", começaram a surgir planos, programas, projetos, metodologias e manuais de desenvolvimento, bancos especializados em financiar o desenvolvimento, ajuda ao desenvolvimento, capacitação e formação para o desenvolvimento, comunicação para o desenvolvimento e muitas outras ações para alcançar o desenvolvimento. A corrida em busca deste objetivo ansiado e esquivo ainda não terminou...

Em nome do "desenvolvimento", em nenhum momento os países centrais ou desenvolvidos, ou seja, nossas referências (causadores, em grande parte, do nosso subdesenvolvimento), renunciaram a diversas operações de intervenção interferência nos 
assuntos internos dos países periféricos ou subdesenvolvidos. Os países pobres, por sua vez, em um ato de subordinação generalizado e submissão, aceitaram este estado de coisas sempre que considerados países em desenvolvimento ou em vias de desenvolvimento; ou seja, sempre que se assumissem como seguidores do mandato recebido. $\mathrm{Na}$ verdade, se aceitou (melhor dizendo, se consolidou) uma estrutura de dominação dicotômica: desenvolvido-subdesenvolvido, civilizado-primitivo, avançado-atrasado, pobre-rico, centro-periferia... A partir de tal visualização binária o mundo se organizou para alcançar o "desenvolvimento".

Nas últimas décadas, quase todos os países do mundo considerados não desenvolvidos buscaram o desenvolvimento. Quantos conseguiram? Muito poucos, e isso se aceitarmos que o que conseguiram é realmente "o desenvolvimento".

$\mathrm{Na}$ verdade, quando os problemas começaram a minar nossa fé no "desenvolvimento", passamos a buscar alternativas de desenvolvimento, demos nomes para diferenciá-lo do que nos incomodava, mas seguimos no caminho do desenvolvimento: desenvolvimento econômico, desenvolvimento social, desenvolvimento local, desenvolvimento rural, desenvolvimento sustentável, ecodesenvolvimento, desenvolvimento em escala humana, desenvolvimento local, desenvolvimento endógeno, desenvolvimento com equidade de gênero, codesenvolvimento... Desenvolvimento, em resumo. O conceito de "desenvolvimento", como toda crença, nunca foi questionado, mas simplesmente redefinido.

A região teve um papel importante em gerar revisões contestadoras do desenvolvimento convencional, assim como o estruturalismo ou as diferentes ênfases na teoria da dependência, propondo posições mais novas.

Estas posições heterodoxas e críticas contêm uma importância considerável, mas também sofrem de algumas limitações. Por um 
lado, sua abordagem não conseguiu questionar seriamente os núcleos conceituais da ideia de desenvolvimento convencional entendido como progresso linear, especialmente expressado em termos de crescimento econômico. Por outro lado, cada um desses questionamentos gerou uma onda de análises que não conseguiram se unir nem se articular entre si. Em alguns casos geraram um auge de críticas, inclusive nas propostas, mas logo depois esses esforços foram definhando e as ideias convencionais recuperaram seu destaque.

Mais tarde, e isto é o que mais nos interessa agora, se percebeu que a questão não é simplesmente aceitar um ou outro caminho em direção ao desenvolvimento. Os caminhos até ele não são o maior problema. A dificuldade reside no conceito. Um conceito que ignora totalmente os sonhos e as lutas dos povos subdesenvolvidos, muitas vezes truncados pela ação direta das nações consideradas desenvolvidas. Um conceito, que embora seja uma reedição dos estilos de vida consumistas e predadores dos países centrais, é impossível de ser repetido em nível global. Basta ver que atualmente tudo indica que o crescimento material infinito poderia terminar em um suicídio coletivo. São indisfarçáveis os efeitos do grande aquecimento da atmosfera ou da destruição da camada de ozônio, da perda de fontes de água doce, da erosão da biodiversidade agrícola e silvestre, da degradação dos solos ou do rápido desaparecimento de espaços de habitação das comunidades locais...

Tal estilo de vida consumista e predador não apenas coloca em risco o equilíbrio ecológico global, mas marginaliza cada vez mais massas de seres humanos das (supostas) vantagens do ansiado desenvolvimento. Apesar dos indiscutíveis avanços tecnológicos, nem a fome foi erradicada do planeta.

Para completar, se constatou que o mundo vive um "mau desenvolvimento" generalizado, incluindo os países considerados desenvolvidos: "O sistema mundial está mal desenvolvido por sua 
própria lógica, e é em direção a essa lógica que devemos voltar nossas atenções” (José María Tortosa 2011).

O desenvolvimento pode, inclusive, não ter conteúdo, mas justifica os meios e até os fracassos. Temos aceitado as regras do "vale tudo". Tudo se tolera em nome de sair do subdesenvolvimento. Tudo se santifica em nome de um objetivo tão elevado e promissor. Para que fiquemos ao menos parecidos com os superiores, qualquer sacrificio vale.

Por isso aceitamos a devastação ambiental e social em troca de conseguir o "desenvolvimento". Negamos nossas raízes históricas e culturais para nos modernizarmos, imitando os países avançados, ou seja, modernos. Arquivamos nossos sonhos e nossas propostas. Fechamos a porta às possibilidades do que poderia ser uma modernização própria. Neste caminho, que implica em uma mercantilização extrema, aceitamos até mesmo que tudo se compra e tudo se vende. Assim, para que o pobre saia de sua pobreza, os ricos estabeleceram que, para ser como eles, o pobre deve agora pagar para imitá-los: comprar até o conhecimento deles, negando seus próprios conhecimentos e práticas ancestrais.

No entanto, embora "a ideia de desenvolvimento já seja uma ruína em nossa paisagem intelectual... sua sombra... ainda escurece nossa visão...” (José de Souza Silva, 2011). Em linguagem simples, mesmo quando sabemos que é inútil perseguir o fantasma, a influência deste nos acompanha por muito tempo. Assim, escapamos do desenvolvimento desde que tenhamos a capacidade de imaginar outros mundos e de nos transportarmos para eles.

3 É conhecido como "vale tudo" aquela modalidade de luta onde os combatentes podem usar qualquer arte marcial ou esporte de contato, já que as regras permitem todo tipo de técnicas e formas de enfrentamento.há mais de seis décadas em nome do "desenvolvimento" não foi cumprida. E não se cumprirá. 
Se a ideia de desenvolvimento está em crise em nossa paisagem intelectual, devemos necessariamente questionar o conceito de progresso, entendido como a lógica produtivista de ter cada vez mais, que surgiu com força há uns 500 anos na Europa. Para cristalizar este processo expansivo, o capitalismo consolidou aquela visão que colocou o ser humano, figurativamente falando, fora da natureza. Se definiu a natureza sem considerar a humanidade como parte integrante da mesma. E com isso continuou acelerada a via para dominá-la e manipulá-la.

A humanidade, e não apenas a América Latina, está em uma encruzilhada. A promessa feita há mais de cinco séculos em nome do "progresso" e "reciclada" há mais de seis décadas em nome do "desenvolvimento" não foi cumprida. E não se cumprirá.

\section{O Buen Vivir na filosofia autóctone}

No contexto das discussões pós-desenvolvimentistas se multiplicam os esforços por uma reconstrução e inclusive pela superação da base conceitual, das práticas, das instituições e dos discursos do desenvolvimento. Nesta situação, sem minimizar suas contribuições, há que se superar inclusive as visões heterodoxas, que enfocavam "desenvolvimentos alternativos", quando é cada vez mais necessário gerar "alternativas ao desenvolvimento". É disso que se trata o Buen Vivir.

O Buen Vivir, na realidade, se apresenta como uma oportunidade para construir coletivamente novas formas de vida. O Buen Vivir não é uma originalidade nem uma novidade dos processos políticos do início do século XXI nos países andinos. Nem é uma espécie de superstição ou poção mágica para todos os males do mundo. O Buen Vivir é parte de uma grande busca de alternativas de vida forjadas no calor das lutas da humanidade pela emancipação e pela vida. 
O que é notável e profundo nestas propostas é que estas surgem de grupos tradicionalmente marginalizados. Elas convidam a arrancar pela raiz vários conceitos considerados indiscutíveis. Questionam a ética do "viver melhor" na medida em que supõem um progresso ilimitado que nos convida a uma competição permanente entre os seres humanos. Este é um caminho seguido até agora, que permitiu a alguns viver "melhor" enquanto milhões de pessoas tiveram e ainda têm que "viver mal".

Para entender o que significa o Buen Vivir, que não pode ser simplesmente associado ao "bem-estar ocidental", é preciso começar recuperando a cosmovisão dos povos e nacionalidades autóctones. Este reconhecimento, plenamente, não significa negar uma modernização própria da sociedade, incorporando na lógica do Buen Vivir muitos e valiosos avanços tecnológicos. Tampouco se marginalizam contribuições importantes do pensamento da humanidade, que estão em sintonia com a construção de um mundo harmônico, como se deriva da filosofia do Buen Vivir. Por esta razão, uma das tarefas fundamentais reside no diálogo permanente e construtivo de saberes e conhecimentos ancestrais com a parte mais avançada do pensamento universal, em um processo de contínua descolonização da sociedade.

Em alguns saberes indígenas não existe uma ideia análoga à do desenvolvimento, o que leva a que em muitos casos se rejeite essa ideia (Carlos Viteri Gualinga, 2000). Não existe a concepção de um processo linear da vida que estabeleça um estado anterior e posterior, a saber, de subdesenvolvimento e desenvolvimento; dicotomia esta pela qual devem transitar as pessoas para que alcancem o bem-estar, como acontece no mundo ocidental. Tampouco existem conceitos de riqueza e pobreza determinados pela acumulação ou carência de bens materiais. Sendo uma abordagem holística, é preciso entender a diversidade de elementos a que estão 
condicionadas as ações humanas que proporcionam o Buen Vivir, assim como o conhecimento, os códigos de conduta ética e espiritual na relação com o meio ambiente, os valores humanos, a visão do futuro, entre outros. O Buen Vivir, em suma, constitui uma categoria central da filosofia de vida das sociedades indígenas. Trata-se de uma categoria em constante construção e reprodução.

Nas palavras do teólogo brasileiro Leonardo Boff, "o Buen Vivir aponta uma ética do suficiente para toda a comunidade, e não apenas para o indivíduo. O Buen Vivir supõe uma visão holística e integradora do ser humano, imerso na grande comunidade terrena que inclui, além do ser humano, o ar, a água, o solo, as montanhas, as árvores e os animais; $e$ estar em profunda comunhão com Pachamama (a Terra), com as energias do universo e com Deus."

Embora o Buen Vivir ancestral tenha perdido terreno por causa das práticas e mensagens da modernidade ocidental - digamos, com mais precisão, pela devastação social e ambiental causada pelo capitalismo -, assim como por efeito da perspectiva colonizadora do poder, do saber e do ser, sua contribuição não pode ser esquecida. Sem chegar, absolutamente, a uma idealização equivocada do modo de vida indígena, sua contribuição nos convida a assumir outros "saberes" e outras práticas, nesse caso dos povos e nacionalidades tradicionalmente marginalizados.

A tarefa de reconstrução/construção do Buen Vivir é, portanto, descolonizadora (e despatriarcalizadora, é claro). Estabelece definitivamente uma cosmovisão diferente da ocidental ao surgir de raízes comunitárias não capitalistas. Rompe igualmente com as lógicas antropocêntricas do capitalismo como civilização dominante e também dos diversos socialismos realmente existentes até agora. O Buen Vivir, em suma, propõe uma mudança da civilização.

Além destas visões da nossa América há muitas outras abordagens de pensamentos filosóficos de alguma forma relacionadas à 
busca do Buen Vivir ou sumak kawsay, partindo de posições filosóficas inclusivas. O sumak kawsay, como cultura da vida, sob diversos nomes e variantes, foi conhecido e praticado em diferentes períodos nas diferentes regiões da Mãe Terra. Aqui caberia destacar outras contribuições humanistas, como as do Svaadeshi de Gandhi ou como as das ecofeministas deVandana Shiva, por exemplo. Neste esforço coletivo para reconstruir/construir um quebra-cabeças de elementos sustentadores de novas formas de organização da vida, se pode recuperar elementos da "vida boa" de Aristóteles; ainda que o seu pensamento possa ser considerado como um dos pilares da questionada civilização ocidental.

Disso tudo o que falamos se deduz que não há uma única visão. $\mathrm{O}$ Buen Vivir não sintetiza uma proposta monocultural. O Buen Vivir é um conceito plural - melhor seria falar de "bons viveres" ou "bons conviveres" - que surge especialmente das comunidades indígenas, sem negar as vantagens tecnológicas do mundo moderno ou as possíveis contribuições de outras culturas e saberes que questionam diferentes pressupostos da modernidade dominante. O Buen Vivir, como é fácil de entender, nos obriga a repensar a forma atual de organização da vida, no campo e na cidade, nas unidades produtivas e nos espaços de convivência sociais, nos centros educativos e de saúde, etc.

\section{A natureza no centro do debate}

Lembremos que desde os primórdios da humanidade o medo dos elementos imprevisíveis da natureza esteve presente na vida cotidiana. Gradualmente, a ancestral e difícil luta pela sobrevivência foi se transformando em um desesperado esforço para dominar as forças da natureza. Se chegou a ver o ser humano fora da natureza. Se definiu a natureza sem considerar a humanidade como 
parte integrante da mesma. Com o capitalismo se abriu definitivamente a porta para dominá-la e manipulá-la. Isto levou a uma espécie de corte do nó górdio da vida. Se separou o ser humano da natureza, transformando esta em uma fonte de negócios aparentemente inesgotável...

Esta é o ponto de partida para entender a conquista e colonização da América, que cristalizou uma exploração impiedosa dos recursos naturais, com o consequente genocídio das populações indígenas e a posterior incorporação de escravos proveninetes da África no mercado global nascente. Desde então se forjou um esquema extrativista de exportação da natureza a partir das colônias em função das exigências de acumulação de capital das metrópoles.

Depois de alcançada a independência da Espanha, os países da América Latina continuaram a exportar recursos naturais, quer dizer, a natureza. E esta visão de dominação se mantém até hoje em muitos setores da sociedade (como se se tratasse de um DNA insuperável), sobretudo em nível governamental, inclusive naqueles considerados como regimes progressistas da região.

Para começar a enfrentar esta mensagem antiga, sustentada por uma ruptura profunda da economia e da natureza, deve-se resgatar a verdadeira dimensão da sustentabilidade. Esta exige uma nova ética para organizar a própria vida. É preciso reconhecer os limites biofísicos das atividades desenvolvidas pelos seres humanos. A realidade nos mostra exaustivamente que a natureza tem limites. E estes, aceleradamente alcançados pelo estilo de vida antropocêntrico particularmente exacerbado pelas exigências de acumulação de capital, são cada vez mais evidentes e insustentáveis.

A tarefa é simples e ao mesmo tempo complexa. Em vez de manter a ruptura entre a natureza e o ser humano, o desafio passa a ser propiciar seu reencontro, algo como tentar amarrar o nó górdio rompido pela força de uma concepção de vida que mostrou 
ser destruidora e certamente intolerável. Os objetivos econômicos devem estar subordinados às leis de funcionamento dos sistemas naturais, sem perder de vista o respeito à dignidade humana e a melhoria da qualidade de vida das pessoas. $\mathrm{O}$ crescimento econômico é apenas um meio, não um fim.

Escrever esta mudança histórica é o maior desafio da humanidade se não se quer colocar em risco a própria existência dos seres humanos na Terra. A Constituição equatoriana de 2008 deu um passo pioneiro nesta direção: a natureza se tornou um sujeito de direitos.

Dotar a natureza de direitos significa, então, incentivar politicamente sua transformação de objeto a sujeito, como parte de um processo centenário de ampliação dos sujeitos de direito. Ao longo da história legal, cada ampliação dos direitos era impensável, anteriormente. A emancipação dos escravos ou a extensão dos direitos aos afroamericanos, às mulheres e às crianças foram antes rejeitadas por serem consideradas um absurdo, inclusive sendo consideradas carentes de fundamento ideológico e jurídico. Tem sido requerido, ao longo da história, que se reconheça "o direito de ter direitos", e isso se conseguiu sempre com um esforço político para mudar as visões, costumes e leis que os negavam. É curioso notar que muitas pessoas que se opuseram e se opõem à ampliação destes direitos não têm vergonha alguma em dar direitos quase humanos a pessoas jurídicas... Uma das maiores aberrações do Direito. O principal dos direitos da natureza é resgatar o "direito de existir" dos próprios seres humanos. Sua vigência, como proposta política e não somente jurídica, suscita profundas mudanças. Isso nos obriga a transitar do antropocentrismo atual ao biocentrismo. Talvez devêssemos falar, de forma mais correta, de um sociobiocentrismo que teria que se concretizar em um novo socialismo, de novo tipo. Mudança que exige um processo contínuo e plural. A tarefa é 
organizar a sociedade e a economia, preservando a integridade dos processos naturais, garantindo os fluxos de energia e de materiais na biosfera, sem deixar de sustentar a biodiversidade do planeta. E tudo isso, melhorando as condições de vida de todos os habitantes do mundo. Uma abordagem política que pressupõe a superação do capitalismo: assim tão fácil e tão complexo é o desafio.

Nos Direitos Humanos, o centro está na pessoa. Trata-se de uma visão antropocêntrica. Nos Direitos da Natureza, o centro está na natureza, que certamente inclui o ser humano. A natureza vale por si mesma, independentemente da utilidade ou uso para o ser humano. Este aspecto é fundamental se aceitarmos que todos os seres vivos têm o mesmo valor ontológico, o que não implica que todos sejam idênticos. Isso é o que representa uma visão biocêntrica.

Estes direitos não defendem uma natureza intocada, que nos leve, por exemplo, a deixar de ter cultivos, pesca ou criação de animais. Estes direitos defendem manter os sistemas, os conjuntos de vida. Sua atenção se fixa nos ecossistemas, nas coletividades. Se pode comer carne, peixe e grãos, por exemplo, enquanto seja assegurado que os ecossistemas permaneçam funcionando com suas espécies nativas.

Aos direitos da natureza chamamos direitos ecológicos, para diferenciá-los dos direitos ambientais. Neste campo, a justiça ecológica visa assegurar a persistência e a sobrevivência das espécies e seus ecossistemas, como conjuntos, como redes de vida. Esta justiça é independente da justiça ambiental. Não é de sua incumbência a indenização aos seres ambientais pelo dano ambiental. É expressada na restauração dos ecossistemas afetados. Na verdade, se deve aplicar simultaneamente as duas justiças: a ambiental para as pessoas e a ecológica para a natureza.

Dos direitos da natureza derivam decisões transcendentais. Uma chave tem a ver com os processos de desmercantilização da 
natureza. Para citar alguns exemplos, se deve proibir todas as formas de privatização da água, assumida como um direito humano fundamental, e negar a introdução de critérios mercantis para comercializar os serviços ambientais. Outro ponto fundamental, sem com isso pretender esgotar o tema, está em proporcionar a soberania alimentar. Tudo isso está na Constituição equatoriana.

\section{Rumo à construção de uma economia solidária}

O valor básico da economia, em um regime de Buen Vivir, é a solidariedade. Portanto, busca-se uma economia diferente da atual. Uma economia solidária deve passar longe da competição livre que incentiva o canibalismo econômico entre os seres humanos e que alimenta a especulação financeira. Uma economia solidária exige relações de produção, de intercâmbio e de colaboração que propiciem a suficiência (mais do que apenas a eficiência) e a qualidade, apoiadas na reciprocidade.

O mundo do trabalho no Buen Vivir é parte fundamental da economia solidária, entendida também como economia do trabalho. Portanto, se pleitea o reconhecimento em igualdade de condições de todas as formas de trabalho, produtivo e reprodutivo. Este enfoque se consolida com a inclusão (e não a discriminação), a igualdade de gênero, os direitos reprodutivos no espaço do trabalho. Assim, o trabalho reprodutivo não remunerado das mulheres encontra um espaço próprio e não se satisfaz com sua simples visualização.

O ser humano, ao ser o centro das atenções, é o fator essencial da economia. Nesse sentido, resgatando a necessidade de fortalecer e dignificar o trabalho, se deve proibir qualquer forma de precarização laboral. O não cumprimento das normas trabalhistas deve ser penalizado e punido. Por outro lado, não se pode bloquear o trabalho dos comerciantes e dos artesãos informais. 
Então, se o trabalho é um direito e um dever social, em uma sociedade que busca o Buen Vivir, qualquer forma de desemprego não pode ser tolerada. O desafio do Buen Vivir, que em grande parte está associado ao tema do trabalho, terá que se resolver pelo lugar que se dá ao trabalho humano, não simplesmente para produzir mais, mas para viver bem. Estando as coisas em sua devida ordem, o trabalho contribuirá para a dignificação da pessoa. Será, então, indispensável prever a redução do tempo de trabalho e sua redistribuição, aumentando outras atividades criativas do ser humano.

Terá igualmente que processar, em base de igualdade real, a redefinição coletiva das necessidades axiológicas e existenciais do ser humano em função de necessidades ajustadas às disponibilidades da economia e da natureza. Mais cedo do que pensamos, será necessário dar prioridade a uma situação de suficiência, contanto que se busque aquilo que é suficiente, em função do que realmente se necessita, em vez de uma sempre maior eficiência sustentada sobre as bases de uma competitividade descontrolada e um consumismo desenfreado, que ameaçam os próprios fundamentos da sociedade e da sustentabilidade ambiental.

Do que expusemos aqui, se deduz que é indispensável ter em mente que Buen Vivir exige uma revisão profunda do estilo de vida de toda a sociedade, começando por desmontar o atual estilo de vida das elites que serve como marco orientador (inalcançável) para a maioria da população.

Já não se trata somente de defender a força de trabalho e de recuperar o tempo de trabalho excedente para os trabalhadores, ou melhor, de opor-se à exploração da força laboral. Está em jogo, além disso, a defesa da vida contra os esquemas de produção antropocêntricos, causadores da destruição do planeta por meio da degradação ambiental. E, certamente, trata-se de continuar a luta para eliminar as desigualdades de gênero, étnicas, intergeracionais... 
Esta transformação, certamente, deveria ser extensiva a todas aquelas formas de produção, como a extrativista, que sustentam as bases materiais do capitalismo. Os países produtores e exportadores de matérias-primas, quer dizer, de natureza, inseridos como tais de forma submissa no mercado mundial, são funcionais para o sistema de acumulação capitalista global e são também indireta ou diretamente causadores dos problemas ambientais globais. $\mathrm{O}$ extrativismo ${ }^{4}$, em última análise, não é compatível com o Buen Vivir, não só porque depreda a natureza, mas porque mantém uma estrutura laboral exploradora da mão-de-obra, à qual, além de tudo, não é assegurado um emprego adequado.

Disso concluímos que a própria organização da economia deve mudar de forma profunda. O mercado por si só não é a solução, tampouco o Estado sozinho. Subordinar o Estado ao mercado conduz a subordinar a sociedade às relações mercantis e ao egoísmo individualista. Longe de uma economia determinada pelas relações mercantis, o Buen Vivir promove uma relação dinâmica e construtiva entre mercados, Estado e sociedade. Se procura construir uma sociedade com mercados múltiplos para não se ter uma sociedade de mercado, ou seja, mercantilizada. Não se deseja uma economia controlada por monopolistas e especuladores. Tampouco se promove uma visão estatista extrema da economia.

Os mercados precisam de uma reconceituação política, que conduza a regulamentações adequadas. Os mercados refletem relações sociais submetidas às necessidades dos indivíduos e das coletividades. Eles devem ser entendidos como espaços de troca de bens e serviços em função da sociedade e não só do capital. E mais,

4 Utiliza-se o rótulo de extrativismo em sentido amplo para as atividades que removem grandes volumes de recursos naturais, que não são processados (ou que o são de maneira limitada), e passam a ser exportados." (Gudynas 2009b) 
o bom funcionamento dos mercados, para os fins instrumentais que a sociedade lhes designa, exige que estes não sejam completamente livres. Os mercados livres nunca funcionaram bem e terminaram em desastres econômicos de vários tipos. De nenhuma maneira se pode acreditar que todo o sistema econômico deve estar imerso na lógica dominante de mercado, pois há muitas outras relações que se inspiram em outros princípios de importância inquestionável; por exemplo, a solidariedade para o funcionamento da segurança social ou beneficios sociais, e em outras áreas como alimentação, saúde e habitação. Reflexão semelhante se poderia fazer para a garantia da Educação Pública, defesa, transporte público, serviços financeiros e outras funções que geram bens públicos que não são produzidos e são regulados através da Oferta e da Procura. Nem todos os agentes da economia, além disso, são motivados pelo lucro.

Concretamente, deve-se organizar e controlar o mercado, mas não assumi-lo como um mecanismo de dominação. Os mercados deverão ser civilizados; isto implicará em regulamentações e intervenções estatais, assim como uma crescente participação da sociedade.

Tal reflexão é válida se recordarmos dos fracassos daquelas opções estatais ao extremo. Esta nova economia consolida o princípio do monopólio público sobre os recursos estratégicos, mas por sua vez estabelece uma dinâmica de uso e aproveitamento deles sob uma ótica sustentável, com a necessidade de dispor de mecanismos de regulação e controle na prestação de serviços públicos por parte da sociedade. Igualmente, durante a etapa de transição, considera as diversas formas de fazer economia: estatal, pública, privada, mista, comunitária, associativa, cooperativa... A função social da propriedade é incluída tanto quanto sua função ambiental.

Para lidar com a gravidade dos problemas existentes e construir uma nova economia é indispensável desarmar as visões 
simplificadoras e compartimentadas. Também não devem existir receitas, quer dizer, uma lista indiscutível de ações a seguir. Ainda está em nossas memórias o fracasso retumbante de um mundo ao qual se quis organizar em torno do mercado, a partir da receita inspirada no Consenso de Washington.

Temos agora a oportunidade de incorporar de forma criativa as múltiplas instituições de produção e intercâmbio indígenas. ${ }^{5}$ Sua conotação e validade devem ser analisadas e até recuperadas se o que se quer é potencializar as raízes de sociedades diversas e culturalmente ricas. $\mathrm{Na}$ sociedade indígena existe amplo tecido e tramas sociais nos quais se inter-relacionam amplamente ações baseadas na reciprocidade, solidariedade e correspondência. Sem negar a influência perniciosa do capitalismo, são relações muito profundas e enraizadas nos costumes e práticas cotidianos. A vida transcorre em função da sociedade. $\mathrm{O}$ indivíduo está ligado ao ambiente social. E a comunidade, com todos os seus indivíduos, está em estreita relação com a natureza.

Sem pretender esgotar o assunto, podemos mencionar algumas formas de relação econômica próprias das comunidades indígenas:

- Minka (minga): É uma instituição de ajuda recíproca no âmbito comunitário. Garante o trabalho desenvolvido para o bem comum da população. É feito para atender às necessidades e interesses coletivos da comunidade. Por exemplo, na execução de obras como a construção e manutenção de um canal de irrigação ou de uma estrada. É, portanto, um mecanismo de trabalho coletivo que permite superar e enfrentar o descaso e a exclusão do sistema

5 Aqui se podem consultar os trabalho de Quisantuña Sisa (2011) ou Torre y Sandoval (2004). O autor também agradece os comentários de Yuri Guadinango. 
colonial e republicano. Além disso, esta instituição tem ajudado as comunidades a potencializar sua produção, incentivar seu trabalho e promover a poupança. A minka é também um poderoso ritual cultural e cerimonial de convocação e coesão das comunidades, assim como um espaço de intercâmbio de normas socioculturais.

- Ranti-Ranti: Ao contrário do escambo pontual e único que ocorre em algumas economias mestiças, o intercâmbio faz parte de uma cadeia que leva a uma série interminável de transferências de valores, produtos e jornadas de trabalho. Se apoia no princípio de dar e receber sem determinar uma classificação de tempo, ação e espaço, relacionado a certos valores da comunidade em relação à ética, à cultura e ao conteúdo histórico (este princípio está presente em todas as ações que se explicam depois). Por exemplo, aqui cabe a troca de mãos no trabalho agrícola, quer dizer, a força de trabalho que se oferece a outra pessoa para receber, depois de um certo tempo, aquela mesma força de trabalho. Trata-se de realizar uma atividade de forma solidária, "primeiro você e depois eu".

- Makimañachina:É um acordo entre indivíduos para realizar um trabalho específico de qualquer tipo, que não envolva remuneração salarial. A única condição é que aqueles que receberam ajuda em seu trabalho retribuam-na em outra oportunidade à pessoa que a concedeu. Equivale a uma ajuda que a família ou os amigos oferecem a quem a requer para a continuação de suas atividades. 
- Makipurarina: Significa conjugar forças para fazer um trabalho que beneficie a muitos, unindo-se entre si ou iguais. Por meio deste compromisso se pode ajudar em qualquer trabalho que não envolva necessariamente toda a comunidade, como no caso da minka. Através deste mecanismo se pode avançar em atividades previamente iniciadas por familiares, amigos, vizinhos ou amigos de outras áreas. Serve para unir forças e fortalecer os laços comunitários.

- Uyanza: É uma instituição de apoio social e reconhecimento às famílias que deram sua força de trabalho como préstimo. $\mathrm{O}$ credor dessa força de trabalho tem a obrigação moral de reconhecer este apoio através de uma doação, seja uma porção da colheita ou algum outro presente.

- Chukchina, chalana ou challina: Significa coletar os restos das colheitas. Este um direito de todas as pessoas que fizeram parte do processo de produção, fornecendo sua força de trabalho no makimañachina. Também os órfãos, viúvas e outras pessoas que não possuem o produto podem ter acesso à chukchina. Além disso, é dado a eles uma pequena porção de produtos agrícolas em solidariedade à situação limitada que estão passando no momento. Assim, nada desperdiçado. Esta opção, no entanto, também reflete a desigualdade em que as comunidades vivem. Além disso, a chukchina é possível quando existem grandes extensões de terra e de culturas. A maioria das comunidades agora vive em pequenas propriedades, onde esta ação não é possível. 
- Uniguilla: É uma atividade destinada ao intercâmbio para complementar a alimentação, os utilitários. Permite melhorar a dieta alimentar com produtos de outras áreas. As pessoas que vivem em locais remotos trocam seus alimentos. Esta atividade parte do conhecimento do calendário agrícola. Este é um processo de troca, complementação e abastecimento das despensas nas temporadas quando não há colheita ou a produção é deficiente.

- Waki: Concessão de terras cultiváveis ao partir a outra comunidade ou família ambas comunidades ou famílias. Essa atividade também ocorre no cuidado e criação de animais.

- Makikuna: Uma ajuda que envolve toda a comunidade, família ampliada, amigos, vizinhos. É uma espécie de apoio moral no momento em que mais se precisa de uma família. Esta ajuda pode ser pedida, mas também obedece a situações inesperadas e emergenciais.

Esta lista pode ser ampliada. Cabe apenas mencionar uma série de ações e práticas adicionais como a tumina, a probana, a yapa, a pampamesa, o kamari etc. Todas estas são formas de relacionamento solidário, recíproco e de corresponsabilidade entre os indivíduos, assim como entre as diversas comunidades e certamente de todas elas com a natureza. Muitas destas práticas poderiam ser resgatadas e aplicadas para a construção de uma nova economia que se encontre a serviço da humanidade, integrada harmonicamente com a natureza.

Certamente estes princípios básicos de reciprocidade e solidariedade exigem ser construídos desde o lar e nos centros de 
ensino primário, assim como nas diversas instâncias da vida dos seres humanos. Não se trata de ações de caridade em meio a um ambiente de crescente competitividade. Tenhamos em mente que a humanidade não é uma comunidade de seres agressivos e brutalmente competitivos. Estes valores são criados por civilizações que têm favorecido o individualismo, o consumismo e a acumulação agressiva de bens materiais, como tem sido a civilização capitalista. Cientificamente já foi comprovada a tendência natural dos seres humanos e animais superiores à cooperação e assistência mútua. Então, é preciso recuperar e fortalecer esses valores.

\section{O Buen Vivir incorporado em um debate global}

O Buen Vivir, enquanto proposta de construção, questiona o conceito ocidental de bem-estar, e, enquanto proposta de luta, enfrenta a perspectiva colonizadora do poder. Então, sem minimizar esta contribuição do mundo indígena, tradicionalmente marginalizado, devemos aceitar que a visão andina e amazônica não é a única fonte de inspiração para impulsionar o Buen Vivir.

É importante ressaltar as contribuições amazônicas. Estas não se limitam às regiões amazônicas do Equador e da Bolívia. Em toda a Amazônia há grupos indígenas que mantêm relações harmoniosas com a Amazônia e, certamente, dentro de suas comunidades. Aqui há um potencial enorme a ser explorado e aproveitado.

Do que foi falado até agora deriva a necessidade de restaurar as práticas das comunidades indígenas, assumindo-as como são, sem idealizá-las. Certamente não se trata de remendar o Estado atual. Não se planeja um simples acréscimo de ideias indígenas às estruturas atuais para construir um Estado diferente do atual. Não se propõe uma justaposição de propostas e visões indígenas e não indígenas. O Estado plurinacional não é um Estado híbrido. 
Tem que ser outro estado, em termos de outra sociedade e outra proposta de vida, que é o Buen Vivir. Disso se conclui que a plurinacionalidade, existente na região, implica outros projetos de país.

Outro ponto importante está no reconhecimento de que o Buen Vivir não pode ficar confinado ao mundo rural. É verdade que as propostas básicas provêm especialmente deste âmbito. Mas também é certo que cada vez mais pessoas vivem em cidades e que, portanto, é preciso respostas para esses amplos grupos humanos, muitos deles marginalizados e explorados. Os espaços urbanos existentes surgem longe de práticas de vida solidárias e de respeito ao meio ambiente. Este é um dos maiores desafios, pensar o Buen Vivir para e a partir das cidades. A tarefa passa por repensar as cidades, redesenhá-las e reorganizá-las ao mesmo tempo em que se constroem outras relações com o mundo rural.

Somando-se a isso, os povos e nacionalidades ancestrais do Abya Yala não são os únicos portadores dessas propostas. $\mathrm{O}$ Buen Vivir forma parte de uma longa busca de alternativas de vida forjadas no calor das lutas da humanidade pela emancipação e pela vida.

Inclusive em círculos da cultura ocidental se levantaram, e desde muito tempo, diversas vozes que poderiam estar de alguma maneira em sintonia com essa visão indígena e vice-versa. $\mathrm{O}$ conceito de Buen Vivir não só tem uma ancoragem histórica no mundo indígena como também se sustenta em alguns princípios filosóficos universais: aristotélicos, marxistas, ecológicos, feministas, cooperativistas, humanistas...

Além disso, no mundo se compreende, aos poucos, a inviabilidade global do estilo de vida dominante. O Buen Vivir, então, projeta-se, além disso, como uma plataforma para discutir respostas urgentes contra os efeitos devastadores das alterações climáticas em nível planetário. Nesse sentido, fala-se inclusive da "revolução mundial do Buen Vivir" (Raúl Prada Alcoreza). 
Esta reivindicação de uma grande transformação orientada para mudar o paradigma não pode ser imposta como o foi o desenvolvimento (leia-se inclusive o progresso mecanicista). A reivindicação formal por ações globais. A humanidade está cada vez mais fadada a enfrentar os problemas globais em conjunto de modo que as soluções para estes problemas inevitavelmente adquirem características globais. Partindo disso, as propostas devem ser plurais. Isso implica o respeito às diversas formas de vida, quer dizer, de organização da sociedade sempre que, ao menos, esta nova organização social e econômica esteja enquadrada dentro dos limites biofísicos da natureza e que erradique estruturalmente a pobreza tanto como a opulência de uns poucos que explica a grande miséria das massas.

Embora seja um ponto fundamental, o crescimento material não é a única maneira a que deveria se dar necessariamente prioridade. A concepção (equivocada!) do crescimento baseado em recursos naturais inesgotáveis e em um mercado capaz de absorver tudo o que foi produzido não conduziu e nem vai conduzir ao desenvolvimento. ${ }^{6}$

Esta constatação, embora seja contraditória, na prática não se incorporou na gestão governamental dos dois países onde se introduziu constitucionalmente o Buen Vivir ou o Viver Bem: Bolívia e Equador. Na gestão destes governos, considerados progressistas, mantém-se a importância dos setores extrativistas. Este extrativismo

6 O capitalismo global necessita urgentemente de certas regras e instituições para conter suas principais aberrações como parte de um processo que conduza à sua morte. Se o capitalismo é essencialmente um sistema de valores sustentado pela acumulação incessante de capital e constitui a civilização da desigualdade, que devasta a própria vida, é preciso construir outras bases civilizatórias. Neste empenho deve-se considerar várias soluções em muitos campos da vida humana: comercial, financeiro, ecológico, cultural... 
é novo pela combinação de velhas e novas características, mas não apresenta mudanças consideráveis no modo de acumulação primário exportador de origem colonial. O destaque deste neoextrativismo é um maior envolvimento do Estado na gestão do setor exportador primário e na distribuição da renda de mineração ou petróleo. No entanto, este extrativismo do século XXI sustenta a integração internacional subordinada e funcional à globalização do capitalismo transnacional. Além disso, este extrativismo exacerbado faz pressão a favor de uma crescente fragmentação territorial e da consolidação de enclaves extrativistas associados aos mercados globais. E tudo isso com crescentes impactos sociais e ambientais. ${ }^{7}$

Mais além da recuperação (parcial) da propriedade dos recursos por parte do Estado, reproduzem-se regras e o funcionamento dos processos produtivos voltados a forçar a competitividade externa, a eficiência, a maximização da renda e a externalização dos impactos ambientais e sociais. A influência das lógicas de acumulação transnacionais, além dos discursos nacionalistas, ainda existe nestes países. A lista de inconsistências nos governos progressistas, tanto em nível nacional como de territórios descentralizados, chama a atenção para intenções distintas entre os mandatos constitucionais e a "real politik" de formas continuístas de consumismo, refletindo também o uso propagandístico do termo Buen Vivir. Basta ver a quantidade de documentos e programas oficiais que anunciam o fim do Buen Vivir como pauta publicitária. Por exemplo, projetos municipais para melhorar as ruas são apresentados como se o Buen Vivir se tratasse disso, em cidades construídas em torno da cultura do automóvel, e não de seres humanos. Da mesma forma, enquanto se aprofunda o extrativismo com a megamineração ou a

7 Sobre este tema pode-se consultar os textos de Eduardo Gudynas (2009b) ou do mesmo autor destas linhas (2011b). 
expansão da fronteira petrolífera, surgem programas governamentais marcados como sendo do "Buen Vivir". Tudo isso representa um sumak kawsay propagandístico e burocratizado, carente de conteúdo, reduzido à condição de produto final.

Dogmatizar e imaginar o Buen Vivir a partir de visões "teóricas" inspiradas em ilusões ou utopias pessoais poderia terminar reproduzindo delírios civilizatórios e também de colonizadores. Assim, podemos até mesmo colocar nomes no Buen Vivir (Buen Vivir sustentável, Buen Vivir com igualdade de gênero, Buen Vivir endógeno?) da mesma forma como fizemos com o desenvolvimento quando quisemos diferenciá-lo daquilo que nos incomodava. Concluindo, o extrativismo do século XXI é parte de uma versão contemporânea do desenvolvimentismo, próprio da América do Sul. Mantém-se o mito do progresso, que não tem nada a ver com o Buen Vivir.

O ambiente internacional pressiona para sustentar esta situação. Particularmente as empresas chinesas "foram às compras" em todo o mundo em meio à crise. Aproveitando suas grandes reservas monetárias e financeiras, bem como utilizando o seu crescente poder político e financeiro, a China começou a adquirir cada vez mais ativos em todos os continentes, expandindo rapidamente sua área de influência.

Estas pressões também encontram suas raízes na região. $\mathrm{O}$ Brasil avança no processo de submissão de seus países vizinhos. Esta tarefa é incentivada através de vários mecanismos. Os créditos do BNDES desempenham um papel fundamental tanto para assegurar recursos na região como para financiar importantes obras de infraestrutura nos países vizinhos às grandes empresas brasileiras. E certamente estas ações se dão no marco da "Iniciativa para la Integración de la Infraestructura Regional Sudamericana" (IIRSA), que remonta aos anos neoliberais, constituindo um 
projeto para vincular ainda mais a América Latina às exigências da acumulação do capital global. A proposta exportadora do Brasil exige muito dos mercados de seus vizinhos, considerando-os vias de traslado e saída de seus produtos fora da região.

Além disso, o Brasil também se assegura de contribuições de energia importantes de vários de seus vizinhos. Não se trata só do gás da Bolívia ou do petróleo em outros lugares. Por exemplo, há grandes projetos hidrelétricos em andamento no Peru. Será produzida energia elétrica no país andino para alimentar a crescente demanda energética do Brasil, que força seu desenvolvimento (ou melhor: seu crescimento econômico) a todo custo, sem se importar com a inundação de bosques ou de terra fértil, o desmatamento, a eliminação da fauna...

O capitalismo periférico brasileiro, um subimperialismo em essência, transfere os custos da imposição deste tipo de integração transnacional aos países vizinhos. Em suma, assistimos a vários processos de desapropriação como os entende David Harvey e, até mesmo, a uma espécie de acumulação primitiva geral, com características semelhantes às colocadas por Karl Marx. Processos que são viáveis graças à cumplicidade de governos que enaltecem teses progressivas e que inclusive se comprometeram constitucionalmente a andar por um caminho de alternativa ao desenvolvimento.

Isso não é tudo. Além da maioria da população mundial não estar desfrutando de bem-estar material, a segurança, a liberdade e a identidade dos seres humanos estão sendo afetadas. A propagação global de certos padrões de consumo, em uma pirueta de perversidade absoluta, infiltra-se no imaginário coletivo até mesmo naqueles amplos grupos humanos sem capacidade econômica para ascender, sem meios financeiros para ter acesso a esse consumo, mantendo-os presos ao desejo permanente de alcançá-lo. 
Este mau desenvolvimento, gerado a partir de cima, seja pelos governos centrais, pelas empresas transnacionais ou elites dominantes em nível nacional nos países subdesenvolvidos, tão peculiar ao sistema capitalista, implica então em uma situação de complexidades múltiplas que não podem ser explicadas a partir de versões monocausais.

Nesta linha de reflexão, a partir da vertente ambiental, e não só dela, poderíamos mencionar as reivindicações de mudança na lógica do desenvolvimento, cada vez mais urgentes, de muitos pensadores de valor. Seus questionamentos das estratégias convencionais se nutrem de uma ampla gama de visões, experiências e propostas extraídas de diversas partes do planeta, inclusive algumas a partir das próprias raízes da civilização ocidental.

Há consciência dos limites biofisicos existentes. Não se pode cair na armadilha de um conceito de "desenvolvimento sustentável" ou "capitalismo verde". O capitalismo, demonstrando sua surpreendente e perversa inteligência para procurar e encontrar novos espaços de exploração, está colonizando o clima. Este exercício neoliberal extremo, do qual não se livram os governos "progressistas" da região, transforma a capacidade da Mãe Terra em um negócio para reciclar o carbono. E o que causa indignação é que a atmosfera é transformada cada vez mais em um novo produto projetado, regulado e administrado pelos mesmos atores que causaram a crise climática e que recebem, agora, subsídios dos governos com um complexo sistema financeiro e político. Este processo de privatização do clima se iniciou na época neoliberal, impulsionado pelo Banco Mundial, pela Organização Mundial do Comércio e por outros tratados complementares. Esta é, sem dúvida, a (pen) última fronteira de colonização do capitalismo.

Sabemos que o mercantilismo ambiental, exacerbado há muitas décadas, não contribuiu para melhorar a situação; apenas foi uma 
espécie de maquiagem inconsequente e diversionista. Sabemos os riscos de uma confiança desmedida na ciência, na técnica. É necessário construir novas formas de organização da própria vida.

Concordamos, então, que o Buen Vivir não sintetiza nenhuma proposta plenamente desenvolvida, muito menos indiscutível. Ele não pretende assumir o papel de um mandato global, mas sim uma construção que serve para desarmar o objetivo universal de todas as sociedades: o progresso em sua manobra produtivista e o desenvolvimento como direção única, sobretudo em sua visão mecanicista do crescimento econômico, assim como seus múltiplos sinônimos. Assim, não só os desarma como propõe uma visão diferente, muito mais rica em conteúdo e, certamente, mais complexa.

Cada país deverá encontrar seu caminho. O Brasil, enorme em muitos sentidos, com uma grande diversidade cultural, ecológica e humana tem grandes potenciais para viajar por um caminho que lhe permita proporcionar a grande transformação de uma maneira mais autônoma que seus vizinhos. No entanto, tem uma enorme responsabilidade histórica para forçar outro tipo de integração regional. Sem uma integração solidária e complementar dos países da Nossa América, elevada à condição de projeto histórico regional, não há a possibilidade de superar as condições atuais de deterioração social e econômica existentes. Esse é um passo fundamental para que os povos da região possam inclusive ser inseridos com dignidade e inteligência no contexto global; inserção que não pode ser o princípio e o fim do acionar econômico de nossos país.

A sexta economia do mundo não deve medir suas realizações em uma competição insana internacional, mas na construção de condições de vida dignas para toda sua população, inclusive para as populações dos países vizinhos.

No Brasil, o país que controla mais da metade da Amazônia, não se pode continuar atropelando a natureza simplesmente para 
competir com as grandes potências capitalistas. Em última análise, para seguir aprofundando um modelo de acumulação devastador na área social e ecológica que mostra com clareza seus limites e indica um caminho em direção à barbárie.

Estamos diante de uma luta pela libertação enquanto esforço político que deve começar por reconhecer que o sistema capitalista destrói suas próprias condições biofisicas e sociais de existência. Este é um sistema essencialmente predatório e explorador que "vive de sufocar a vida e o mundo da vida" (Bolívar Echeverría).

O Buen Vivir, finalmente, propõe uma mudança civilizatória. É um caminho que deve ser imaginado para ser construído por cada sociedade, com fins de mudar este mundo e construir democraticamente outro que seja sustentável, justo, igualitário, livre e, seguramente, mais humano.

\section{Referências Bibliográficas}

ACOSTA, Alberto (2010); "El Buen Vivir en el camino del post-desarrollo - Una lectura desde la Constitución de Montecristi", Policy Paper No 9, Fundación Friedrich Ebert. http://library. fes.de/ pdf-files/bueros/quito/07671.pdf

ACOSTA, Alberto (2011); “Los Derechos de la Naturaleza - Una lectura sobre el derecho a la existencia", vários autores (Alberto Acosta y Esperanza Martínez - editores); La Naturaleza con Derechos - De la filosofía a la política, Abya-Yala, série debate constituyente, Quito.

ACOSTA, Alberto (2011b); "Extractivismo y neoextractivismo: Dos caras de la misma maldición”, vários autores, Más allá del desarrollo, Fundación Rosa Luxemburg, Quito, 2011. 
ALCOREZA, R.P. (2010). “La revolución mundial del vivir bien.” Capítulo Boliviano de Derechos Humanos, Democracia y Desarrollo. Available at: http://www.derechoshumanosbolivia. org/ editorial.php?cod_editorial=ED20100507121355 (accessed on Mar. 15, 2012).

DE LA TORRE LUZ, Marina, y Peralta S. Carlos (2004); La reciprocidad en el Mundo Andino, Abya-Yala e ILDIS, Quito.

DE SOUZA SILVA, José; Hacia el 'Día Después del Desarrollo' Descolonizar la comunicación y la educación para construir comunidades felices con modos de vida sostenibles, ALER, 2011 (mimeo).

ECHEVERRÍA, Bolívar (2010); Modernidad y Blanquitud, Editorial ERA, México, 2010. GUDYNAS, Eduardo (2009a). El mandato ecológico. Derechos de la naturaleza y políticas ambientales en la nueva Constitución, serie Debate Constituyente, editores Alberto Acosta e Esperanza Martínez, Abya-Yala, Quito.

GUDYNAS, Eduardo (2009b). "Diez tesis urgentes sobre el nuevo extractivismo. Contextos y demandas bajo el progresismo sudamericano actual," vários autores, Extractivismo, Política y Sociedad, CAAP, CLAES e Fundación Rosa Luxemburg: Quito.

GUDYNAS, Eduardo (2010). "Si eres tan progresista ¿por qué destruyes la naturaleza? Neoextractivismo, izquierda y alternativas", Revista Ecuador Debate, n. 79, CAAP, Quito.

GUDYNAS, Eduardo; ACOSTA, Alberto (2011); "El buen vivir o la disolución de la idea del progreso", in Mariano Rojas (coordenador) do livro La medición del progreso y del bienestar - Propuestas 
desde América Latina, Foro Consultivo Científico y Tecnológico de México, México.

GUDYNAS, Eduardo e Alberto Acosta (2011); "La renovación de la crítica al desarrollo y el buen vivir como alternativa"; na revista Utopía y Praxis Latinoamericana, Revista Internacional de Filosofia Iberoamericana y Teoría Social Centro de Estudios Sociológicos y Antropológicos (CESA) , Facultad de Ciencias Económicas y Sociales, Universidad del Zulia-Venezuela, Ano 16. № 53. Abril-Junho.

HOUTART, Francois (2011); "El concepto del sumak kawsay (Buen Vivir) y su correspondencia con el bien común de la humanidad", Revista Ecuador Debate No 84, Quito, dezembro.

QUISANTUÑA SISA, Mirian Imelda (2011); Prácticas sociales y culturales de las comunidades andinas, una propuesta en la consolidación de economía social y solidaria, monografía do curso de economía social e solidária, FLACSO, Quito.

SHIVA, Vandana (2009); “La civilización de la selva”, in Acosta, Alberto y Martínez, Esperanza (editores); Derechos de la Naturaleza El futuro es ahora, Abya Yala, Quito.

TORTOSA, José María (2011); “Mal desarrollo y mal vivir Pobreza y violencia escala mundial”, editores Alberto Acosta e Esperanza Martínez, série Debate Constituyente, Abya-Yala, Quito.

VITERI GUALINGA, Carlos (2000); "Visión indígena del desarrollo en la Amazonía”, Quito, (mimeo). 


\section{A UTOPIA EM QUESTÃO: DESAlHEAMENTO EDUCACIONAL À OBJETIVIDADE}

Antonio Roberto Faustino da Costa ${ }^{1}$

Pedro Bergamo ${ }^{2}$

Roberto Marden Lucena ${ }^{3}$

\section{Prolegômenos}

Eis um convite-surpresa!

Abrace, conosco, a oportunidade de produzir um texto cujos teores se alinhem a uma "proposta-desafio-esperança"!

Mas, o que dizer sobre tal proposta ir ao encontro de intencionalidade há muito tempo resguardada?

1 Doutor em Educação (UFPB), Professor do Departamento de Comunicação Social e do Programa de Pós-Graduação em Formação de Professores (UEPB) e Líder do Grupo de Pesquisa Formação de Professores e Práxis Educativo-Coletiva.

2 Pós-Doutor em Educação (UNICAMP), Pesquisador Educacional e Mediador do Grupo de Pesquisa-Ação CONSER da Faculdade São Francisco de Barreiras (FASB) e Pesquisador do Grupo de Pesquisa Formação de Professores e Práxis Educativo-Coletiva.

3 Doutor em Educação (UNICAMP), Professor, Diretor Acadêmico e Membro do Grupo de Pesquisa-Ação CONSER (FASB) e Líder do Grupo de Pesquisa Formação de Professores e Práxis Educativo-Coletiva. 
Há surpresa inclusive na própria oportunidade, à medida que esta é comunicada mediante os seguintes e inesperados dizeres:"projeto editorial ensaístico, que visa provocar e mobilizar a comunidade latino-americana para a insurgência: sim, nós temos uma utopia, nós temos esperança, nós queremos um tempo/mundo diferente"4.

Todavia, cumpre de antemão elucidar que alinhamento à insurgência em foco há de assumir certa paradoxalidade quanto a conjugar modéstia e ousadia, em razão de que os teores adiante elaborados se obrigam a prescindir, por óbvia ou real impossibilidade, de recorrer a tão numerosos e renomados autores sobre a utopia. Enfatiza-se, por isso, a existência de abertura para que elaboradores partam "de seu lugar de vida/mundo" e "produza(m) um ensaio provocador, recuperando a necessidade de se despertar do sono profundo em que se encontra o espírito utópico - compreendido aqui em sentido amplo e crítico-dialético, como força mobilizadora das energias emancipatórias da humanidade"

Com efeito, o sentido insurgencial dos teores do texto adiante oferecido adentra "caráter eminentemente casual” (Tertulian, 2010, p. 396), por força de que suas fontes precisaram considerar realidades imediatas, simples e cotidianas, as quais lhes têm impelido a assumir exemplaridade, ao menos esta, de alcance provocador e emancipatório cuja realização venha a harmonizar-se com o renome de algo utópico.

Já esta realização foi inicialmente deflagrada por força de situada inconformidade com a ideia-força da ideologia que insiste em atribuir precisão de sentido público - o comum, segundo Arendt

4 Trata-se de comunicado expedido, via mensagem eletrônica, em 22/10/2015, cujo assunto PROPOSTA - DESAFIO - ESPERANÇA teve por signatário Cidoval Morais de Sousa (Professor PPGDR-UEPB).

5 Id. ibid. 
(2001, p. 59) - a uma ainda imprecisa idealidade do que se encontra em transformação para se tornar propriamente estatal, dado que o vigente estágio desta idealidade não reflete objetividade segundo os inarredáveis limites das projeções do pensar e dos artifícios do agir.

Trata-se de inconformidade à qual seria incabível advir inversão de sentido do que tem sido utópico, se enxergado a partir de fora da ambiência em que está a se intensificar. Já esta ambiência cumpre ser assumida enquanto reflexo de desafios político-institucionais cujo status está a suscitar, segundo Lucena (2015, p. 118-126), questões de entendimento sobre criteriosidade para abordar as relações entre poder político e dominação econômica no interior da ambiência educacional no Brasil.

Essas questões precisam ser examinadas na perspectiva de reduzir o ruído comunicativo em que incorrem as implicações e os desdobramentos das tentativas de qualificar o processo educacional, sobremaneira na esfera universitária deste processo, ao se ter em vista compatibilizar o desenvolvimento humano com o econômico.

Adicionalmente a tal ruído, a criteriosidade em foco precisou exsurgir junto a determinada instituição de ensino superior (IES), à qual cumpre fazer devida deferência, inclusive por estar sediada na peculiaridade sócio-histórica do isolamento que até pouco tempo atrás, início dos anos 1980, caracterizava o "Além São Francisco" da Bahia, visto a partir da metrópole de Salvador/ Brasil. Esta instituição corresponde à Faculdade São Francisco de Barreiras/Bahia (FASB).

Na peculiaridade organizacional desta IES, está institucionalizado um Grupo de Pesquisa-Ação que se denomina CONSER - de "ser junto". Os frequentadores de encontros regulares se

6 Desde 2014, o Grupo de Pesquisa-Ação CONSER/FASB intensifica parceria com o Programa de Pós-Graduação em Formação de Professores (PPGFP) da 
consideram "conserianos", em razão de assumirem uma práxis educativo-coletiva voltada para considerar também a pessoa do(a) educando(a), consideração que persiste a se implicar no desenvolvimento de condizente proposta educacional, mediante orientação recoltada junto à Faculdade de Educação da Universidade Estadual Campinas - São Paulo (Bergamo, 2010).

Dadas as circunstâncias até este ponto apresentadas, cumpre que se volte a enfatizar a oportunidade juntamente com a surpresa de o presente texto atender ao convite de se constituir em um ensaio no sentido de reavivar "o espírito utópico".

Entretanto, este atendimento se obriga a "correr por fora" no contexto da pesquisa institucionalizada e, para tanto, continuará a presumir incomum generosidade, esta em virtude de que educadores se voltem para considerar também a pessoa de quem aprende. Sabe-se que esta pessoa nasce detentora do modo de existir originariamente apenas apropriativo e que relativizar, ao menos isto, esta originária condição de existência implica ultrapassar omissão educacional, em rigor, recorrentemente inconfessa.

Por seu turno, esta ultrapassagem - urge que isto seja dito - adentra desafio cujo enfrentamento, ainda e até certo alcance, também perfaz algo de utópico, a começar pela raridade de linguagem a ser garimpada para comunicar algo aparentemente novo que, em boa medida, incide neste mesmo enfrentamento. Adiante, ao final da subunidade 4 deste texto, é apresentada proposta no

Universidade Estadual da Paraíba (UEPB) e o Instituto Federal de Educação, Ciência e Tecnologia da Paraíba (IFPB), Campus de Picuí-PB, culminando na criação, em meados de 2016, do Grupo de Pesquisa Formação de Professores e Práxis Educativo-Coletiva junto ao Diretório dos Grupos de Pesquisa no Brasil do CNPq (http://dgp.cnpq.br/dgp/espelhogrupo/6797320539538029). 
sentido de expor fontes de causalidade que facultem objetividade para realizar tal ultrapassagem.

Já o entendimento desta objetividade provém de Lukács (2003, p. 20), considerando-se categorias deste pensador na elaboração de inesperado teor prefacial, à sua obra "História e Consciência de Classes: estudos sobre dialética marxista". Neste prefácio de 1967, ele esclareceu que precisaria rever sua obra anterior, tendo em vista reconsiderar a força da objetividade que, em Marx, precisa mediar o intercâmbio orgânico entre natureza e metabolismo humano.

Além dessas considerações, cabe antecipar que os teores do presente texto foram inicialmente colocados de forma distanciada da Filosofia, mas que, ao seu final, este distanciamento passa a ser refletidamente assumido, especialmente em relação ao pensar filosófico pós-socrático. Com efeito, não se recorre à reflexão, mas, propriamente, à imediatidade da emergência do pensar humano, com base, inicialmente, em resquícios que foram salvos da obra de Leucipo (nascido entre 490 e 460 a.C.), em cujo atomismo o vazio se encontraria implicado de modo existencialmente ôntico. Trata-se do pensar que ameaçou, ao menos isto, ser retomado entre meados da década de 1930 até 1976, mediante uma espécie de recusa a filosofar à qual se voltou Martin Heidegger?

Esta imediatidade do pensar cumpriria ocorrer, neste texto, enquanto descortinamento do modo ôntico da existência do vazio, este a respeito de assumir produção inequívoca, assim como da necessidade, por ela mesma, da existência desta mesma produção.

Por utópico que de antemão o pareça, tal descortinamento passa a ser condição para passar a existir o objeto do presente texto, mediante enfrentamento do concernente desafio e da

7 LOPARIC, Zeljko. Como Heidegger, pensador do fenômeno, migrou para o oculto. In: Jornal Folha de São Paulo, Ilustríssima, p. C6-7, 2016. 
paradoxalidade que perfaz este enfrentamento em termos de ousadia e modéstia.

\section{Colocações deflagratórias}

Em Abbagnano (2007, p. 1173-4) consta uma sequência de significados filosóficos da utopia, a partir de Thomas Morus, avaliação da qual se infere falta de acordo entre os concernentes e principais pensadores.

A propósito de tal avaliação cabe destacar a oposição entre ideologia e ciência, dado o entendimento marxiano-engelsiano sobre o alcance científico, este, então, a respeito do porvir socialista, assim como sobre o caráter utópico que foi atribuído por seguidores desse entendimento à versão sobre este mesmo porvir junto a precedentes pensadores, sobremaneira em França.

Por força daquele alcance científico, a desandar em argumento da práxis revolucionária, o socialismo veio a ser considerado mito por Sorel (ib., p. 1173).

Assim, passa-se da ciência ao mito, enquanto a ideologia se sobrepõe à própria ciência e se torna cavalo-de-batalha das numerosas correntes do marxismo.

Todavia, em Mannheim (ib., p. 1173), a ideologia incorre em algo que "nunca conseguiria realizar-se", diversamente da utopia que se destina a realizar-se. Por sua vez, esta realização é enfatizada por Marcuse (ib., p. 1173-4) que chegou a falar de um "fim" da utopia, entendendo este "fim" enquanto realização da própria utopia:

[...] pretendendo aludir, com tal expressão, ao fato de que hoje existem já os espaços, ou seja, as precondições materiais e técnicas, em que as U. (utopias), abandonando os não-lugares da abstração, podem finalmente imergir no real. 
Entrementes, junto aos marxismos, sobremaneira ao ortodoxo, o fim da utopia passou a designar os futuros derrotados pela inevitabilidade do socialismo, enquanto, junto aos próprios candidatos a derrotados, este mesmo fim há de ocorrer por força de que a inevitabilidade em foco é utópica, conquanto não por motivo de perfazer propriamente um mito, mas por não ter como existir.

Adicionalmente a estas designações, cumpre ser ressaltado o posicionamento de Cassirer (ib., p. 1174), para quem a utopia tem função permanente, aquela de "criar espaço para o possível; contra aquiescência passiva ao estado presente".

$\mathrm{Na}$ esteira deste posicionamento, uma determinada crítica à oposição entre ideologia e ciência cabe ser colocada, no sentido de que existe referência e fundamento para prevenir ilimitação apropriativa de uma e de outra, não apenas enquanto forma ou idealidade na esfera do pensamento, como também enquanto prática ou materialidade no âmbito da ação.

Assim preventivamente e por conta de inicial e de a tanto indicada hipótese de trabalho, limitação apropriativa das formas e das práticas, ambas em bases de idealidade e de ciência, tende a injustificar a oposição entre ambas e a fazer com que a realização (da utopia) incida em outridade de seu suporte (material, real ou físico) e de correspondente sentido (ideal, abstrato ou formal).

Nesta perspectiva, não se trata de apenas abandonar os (acima citados) "não-lugares da abstração" de Marcuse, mas de vivenciar, por limitado que o seja, uma realidade que ainda há de persistir objeto utópico, se considerado junto às atuais ilimitações dos resultados do pensar e do agir em humanidades.

Trata-se de suporte que tem como ser reconhecido pelos sujeitos e estes, então, passem a encontrar condições para chegar à criteriosidade que é pressuposta para atribuir limites, tanto às projeções do pensar, quanto às realizações do agir. 
Já esta criteriosidade não tem sido nem mesmo vislumbrada, pois, recorrentemente, vem incidindo em espontâneo ostracismo, à conta da efetividade da mediação de projeções (criações) do pensar e de efeitos (artificios) do agir, ambos - projeções e efeitos - a deterem caráter ilimitado, a exemplo do mito e da guerra, respectivamente.

Por seu turno, este caráter de criações e de artifícios tem sido comum a ideólogos e a cientistas, em razão de que a concernente origem se faz valer "de cima para baixo", a partir de um preposto de instituição cujo "unismo" (identidade entre preposto e instituição) se implica na excludência do que tende a perfazer "unicismo" (excludência de tal identidade). Este unicismo, por seu turno, se tornou característica, não apenas do Poder enquanto projeção de ideologia, mas também do Estado enquanto artifício que historicamente tem incidido no espaço de conquistas violentas e de autorrealização do Poder.

Objeto de caráter assim ilimitado sempre se implicou em indignidade humana cuja ultrapassagem, em rigor, ainda sequer se coloca, apesar de que a custosidade dessa mesma implicação esteja a ocorrer como desperdício, ou mais precisamente, como usurpação da oportunidade de garantir sustentação de fontes ideativas e de meios materiais para constituir algo ainda utópico, ou seja, suporte real da dignidade humana e sentido deste suporte.

Trata-se de constituir o que há de perfazer outridade de coletivo humano cujo sentido cumpre ser inequívoco, por incidir em indeclinável condição para delimitar objetos do pensar e do agir na perspectiva de ultrapassar indignidade e de chegar a determinada dignidade humana. Já esta ultrapassagem se constitui em condição para a existência da (ainda utópica) generidade humana, esta enquanto referência e fundamento a tanto imprescindíveis e ambos 
- referência e fundamento - meramente mediativos e ainda a não ultrapassarem simples potencial na perspectiva de se condizerem com aquele sentido, cuja procedência se torna patente em tudo o que não surge e não se mantém por si mesmo, mas, por ter que existir na perspectiva de que todo ente humano adentre a condição de incidir em um fim em si mesmo e não mais persista reduzido a mero instrumento. Já este fim em si mesmo, sócio-historicamente ineliminável, sempre foi tão apequenado quanto o tem sido possível às ilimitações dos resultados do pensar e do agir.

Constituir algo que perfaça inequívoco sentido do que é coletivo adentra mudança no complexo âmbito do processo inseparavelmente civilizatório e cultural; civilizatório enquanto materializável e cultural enquanto pensável.

Sempre houve necessidade de vir a ocorrer tal mudança, cumprindo atendê-la, apesar de este atendimento persistir utópico na perspectiva de sair do seu recorrente unicismo para a condição de generalidade que cumpre ser comum, homogênea, universal, unívoca enfim.

Retorna-se, assim, àquela outridade de suporte real e sentido pertinente a este mesmo suporte, os quais, em razão de persistirem irreconhecíveis, perfazem caráter utópico. Para que haja consciência de ambos - outridade de suporte e inequivocação de sentido pertinente a este suporte - urge que, primeiramente, prevalência de ideologias seja enxergada em termos do que cabe ser definido como unismo condicionado por unicismo, mas ambos, ao final, desandando em magismo; a seguir, cumpre propor criteriosidade para chegar a limitadas projeções do pensar, às quais correspondam também limitadas realizações do agir, na perspectiva de que ambas - projeções e realizações assim limitadas - adentrem condição para desintensificar, ao menos isto, indignidade humana e para intensificar a prevenção das recorrentes e generalizadas injustificações, ou 
seja, prevenção dos desníveis educacionais, das disparidades econômicas e das desigualdades políticas.

\section{Por aquém do unismo condicionado por unicismo}

Ultrapassagem do clássico-antigo apelo helênico à utopia se implica na pressuposição de constatar, em todos os lugares da Terra, a ausência da realidade, à qual a própria utopia correspondesse, constatação que ainda hoje não se desvela realizável e que, por isso, se caracteriza como ilimitada projeção do pensar.

A Utopia de Morus significou um salto imaginativo que, em alcance até então inusitado, passou a se opor àquela projeção do pensar helênico.

A propósito deste salto, considera-se a representação do objeto imaginado enquanto este mesmo objeto precisou emergir incompatível com a procedência da sua própria representação, conforme tal procedência consta em Hartmann (apud Huisman, 2004, p. 464). Trata-se de procedência que incidiu em crítica ao idealismo, dado que este "despreza o estado de receptividade essencial no qual se encontra a representação humana". Neste estado, "todo conhecimento é conhecimento de alguma coisa que existe antes do homem e que não é produzida por ele" (ib. ibid.).

Nesta última assertiva, entretanto, coloca-se determinada improcedência quanto a representar o próprio produzir, por inadvertido que isto esteja a ocorrer e por inegável que se considere a genialidade do autor. Significa que a produção de coisas adentra um dilema: ou procede somente da natureza, ou teria que perfazer a condição de não se implicar em conhecimento. Esta condição, por sua vez, reduziria produzir a mero trabalho que, inclusive em Marx (apud Lukács, 2010, p. 86), tem como 
deter significado excessivamente espontâneo: "[...] para o trabalho, e para ele com maior razão, vale a frase de Marx sobre a práxis humana, fundamental para a metodologia histórica: eles não sabem, mas fazem"; e, ainda a propósito de trabalho se implicar em conhecimento, resultou até certo ponto frustrante a Marx (2004, p. 108-120) a tentativa de qualificar trabalho enquanto improdutivo e produtivo, pois ao primeiro não há como livrá-lo de materialidades entre si imiscuídas e ao segundo não adentrar redundância representativa.

Para remover aquela determinada improcedência de representar produção, cumpre que se recorra à totalidade compreendida pelo processo de teleologizar, este provindo do próprio Hartmann, enquanto "O engenhoso dissecador da teleologia autêntica" (apud Lukács, 2012, p. 153), uma vez que teleologia é relacionar cognitivamente causalidades com a imagem de um artificio, sobremaneira se este for alternativo, novo ou ainda não conhecido. Paralelamente, este ausente conhecimento das causalidades pressupõe outro conhecimento, aquele da necessidade, tão mais esta se imponha à fonte humana de imaginação.

A Utopia de Morus foi imaginariamente situada em um lugar que é único. Já esta localização, tal como tendencialmente se localizam as ilimitadas projeções do concernente pensar, foi condicionada, em termos culturais e civilizatórios, pela dialética entre os antigos mundos helênico (apropriativista, em rigor unicista) e bárbaro (produtivo, em rigor objetivo). Isto cabe ser afirmado, porque o tratamento nada utópico que Morus sugere aos inimigos dos habitantes da sua Utopia tem tido como rememorar a descomunal violência de Cortés e dos dois Pizarro, o primeiro ao conquistar o México e os segundos o Império Inca, assim como de colonos provindos de certas nações europeias contra indígenas nas Américas, negros em África e aborígenes na Oceania. 
Bárbaro, por origem, era afeito a produzir e trocar utilidades entre tribos de cepa comum, sobremaneira na possibilidade de haver resquícios de parentesco e de linguagem, o que cumpre ser inferido a partir do seguinte depoimento de Aristóteles (2007, p. 68):

\begin{abstract}
"Na família primitiva, tudo era comum a todos, mas, quando ela se dividiu em partes, os objetos foram também divididos entre estas, ficando alguns privados de algumas coisas; daí a necessidade de trocas. Esta prática é verificada ainda hoje entre inúmeros povos bárbaros: se uma tribo tem de sobra o que falta a outra, elas trocam o que possuem a mais; por exemplo, trocam vinho por trigo, e assim por diante. Este gênero de transação não está, pois, contra a natureza nem constitui uma espécie separada de ciência da riqueza, visto que, na origem, não tinha outro fim senão o da satisfação das necessidades da natureza" (Grifos nossos).
\end{abstract}

Por seu turno, o mundo helênico emergiu nas circunstâncias em que agressão passou a ser estrutural, por força de que esta agressão já incidia em defesa preventiva e, conforme Aristóteles (ib., p. 98), as próprias leis vieram a refletir esta incidência: "São os próprios fatos que o comprovam: as leis antigas eram excessivamente simples e bárbaras; os helenos andavam sempre armados e compravam as esposas uns aos outros". (Apelo ao atributo de "bárbaras", até mesmo em uma tradução recente para o linguajar português, é demonstrativo de residuais influências da apontada dialética entre os mundos helênico e bárbaro).

Por força daquela agressão estrutural, o indivíduo - o "um" originário - tende a acumular poderes de forma excludente, o que desanda em se tornar "o único", à medida que a condição de chefe 
tem sido enxertada na pessoa e esta, em o sendo possível, tende a se tornar rei ou imperador, do mundo inteiro inclusive. Trata-se de tendência que o próprio Aristóteles (ib., p. 244) vislumbrou para o povo grego que "se estivesse unido em um único Estado, seria capaz de governar o mundo". (Com efeito, seu discípulo Alexandre Magno chegou a ensaiar tal capacidade, ao conquistar a grande parte da Ásia que era dominada pelo Rei da Pérsia, à época Dario III).

Em tal "unismo condicionado por unicismo", os bárbaros eram importados por gregos - descendentes dos antigos helenos, de maneira emblemática por atenienses - para que se tornassem servos cultivadores das suas terras.

Este tipo de atividade humana, cuja origem está a ser, na atualidade, atribuída às mulheres, já em Hesíodo (apud Aristóteles, ib. p. 55) era primordialmente ilustrativa da mais originária composição de uma família em termos de possível associação entre mulher e boi, uma vez que este, por ser naturalmente apto para o labor, era, então, considerado o escravo dos pobres. Condição menos assim naturalmente apta que essa do boi, era aquela da mulher bárbara que, para os gregos, equivalia à de escravo, enquanto e diversamente, a condição da mulher grega, cuja associação àquela do homem, ou mesmo à de escravo em relação à de senhor, servia para destacar a prerrogativa de toda mulher ser capaz de designar "um fim específico para cada coisa" ou de incidir no "instrumento mais perfeito", aquele de servir para o uso que "lhe é próprio" (ib., p. 54).

Foi da forma assim explicitada que a produção, desde o surgimento da agricultura, tem tido os seus resultados injustamente consumidos: ora, para imemorialmente desaparecerem junto com as concernentes fontes humanas, ora, para historicamente (ao menos a partir de fins do $4^{\circ}$ e início do $3^{\circ}$ milênios a.C.) sustentarem a tendência de o unismo estar condicionado pelo unicismo. 
Por seu turno, esse condicionamento se implicou em um peculiar surgimento das (vigentes) classes sociais, a partir das circunstâncias em que este mesmo condicionamento passou a pressupor três mais explicitados estratos ocupacionais: (1) guerreiros em tempo integral de treinamento e/ou de combate; (2) matrizes de tais guerreiros, estas em não menos imprescindíveis funções sociais; e (3) geradores de meios propriamente necessários àquelas atividades e a estas funções. São circunstâncias que também coincidiram com as condições de emergência do Estado no mundo helênico, o que, segundo Kuczinsky (1985, p. 54-55), somente reuniu tais condições ao início do Século VI (a.C.).

Nestas mesmas circunstâncias, cumpre que seja evocado o aparecimento de bem determinada ocupação, aquela de "pedagogo", dentre cujas atribuições se destacavam, na Antiguidade Clássica, as funções de um escravo liberto que estava encarregado de conduzir crianças ao lugar em que aprendiam bem determinados saberes e condutas. Em alcance estrutural, ou até mesmo de obviedade, tais saberes e condutas não tinham como se incompatibilizar com a recorrência daquelas três classes sociais, uma vez que tinham de ocorrer condicionadas pela oposição entre os mundos helênico e bárbaro (por "unismo condicionado por unicismo”). Todavia, nem mesmo aquele pedagogo vislumbrava que, então, o mundo bárbaro perfazia um pressuposto que se encontrava, espontânea ou inconscientemente, responsável por algo que sempre foi imprescindível à procedência representativa das coisas, ou seja, pelo intercâmbio, orgânico e direto, entre natureza e metabolismo humano.

Trata-se de procedência representativa que preveniria a complicação inerente ao processo cultural e civilizatório em favor de alternatividade propriamente complexa, na mera hipótese de que a alternatividade em foco tivesse sido influenciada por mediação sócio-objetiva, esta no sentido de que povos encontrem condições 
residuais de realizar algo que ainda na atualidade persiste utópico, conforme e até certo ponto, está observado por Browne (1988, p. 23):

[...] em regiões ricas, podem os caçadorescoletores organizar-se em sociedades mais complexas. Mas isso é excepcional: a regra é que se atinja essa maior complexidade social quando a mera apropriação dá lugar à produção, isto é, ao cultivo ou criação.

$\mathrm{Na}$ atualidade histórica, a defesa preventiva recorrentemente estruturada em termos de agressão - esta originariamente contra quem produz de modo inequívoco e, apesar disto ou por isto mesmo, humanamente a se expor à indignidade - ainda impede que aconteça tal excepcionalidade de organização a ser propriamente coletiva, pois tal defesa prevalece mediante atribuição de explícita culpa a determinado modo de produzir, o qual não é mediado por um concernente saber.Já à conta desta culpa, prevalecem meras formas de apropriação, assim como implícita inocência do Estado ao comandar geração e (ab)uso destas mesmas formas.

Todavia, em acordo com Clastres (1988, p.132-152) e testemunhado somente após influências decorrentes da expansão europeia ultramarina em lugares e junto a povos em cujas realidades a produção ainda provinha quase que totalmente da natureza, aquela oportunidade de emergência do Estado talvez já ocorresse em razão de certo agigantamento de uma população em estágio ainda tribal da sua sociabilidade.

A propósito de tal emergência, o retardamento em atender a pertinente necessidade, no Brasil meridional e junto a povos tupisguaranis, é atribuído por este mesmo autor à circunstância de ser impossível que uma eventual chefia se enxertasse em determinado 
indivíduo, mesmo que este se destacasse ao comandar defesas e/ ou agressões contra outros povos também ainda em estágio tribal.

Entretanto, Clastres (ib., p. 118-122) também chegou a prenunciar, por mais implícito ou não proposital que isto tenha acontecido, ocasião para existir determinada realidade que também se prenunciasse como objeto a perfazer o "fim" da utopia em Marcuse, mediante proposição de realidade cuja representação incida no objeto a perfazer este "fim". Tratava-se da imaginária "descendência de um karai guarani” (xamã - pessoa influente, por força de saberes sui generis), ao qual o próprio Clastres atribuiu a autoria de um fragmento de escrita encontrado no fundo de uma floresta do Paraguai: "As coisas em sua totalidade são uma: e para nós que não desejamos isso, elas são más".

Afirma-se que "o Mal é o Um" ou vice-versa (ib., p. 121), a partir da idealização do que uma calculista e astuta deidade (Tupã) ensinava a seu próprio filho, após o dilúvio, para recompor o mundo (ib., p. 118):

Eis o que farás, meu filho. Dispõe os fundamentos futuros da Terra imperfeita... Coloca uma boa malha como fundamento futuro da Terra... é o pequeno porco selvagem que vai provocar a multiplicação da Terra imperfeita... Quando ela tiver alcançado o tamanho que desejamos, eu te prevenirei, meu filho... Eu, Tupã, sou aquele que vela pela manutenção da Terra... (ib., p. 118) [reticências no original].

A deidade em apreço "queria que a nova Terra fosse uma Terra imperfeita, uma terra má, conquanto capaz de acolher os pequenos seres destinados a nela habitarem" (id. ibid.).

Mas, para tanto, terá que voltar à Terra imperfeita e agir contra a fonte de uma bruma que torna inabitável esta mesma Terra: 
Farei com que a bruma seja leve à Terra imperfeita. Somente assim os pequenos seres que enviamos para lá se sentirão revigorados, felizes. Aqueles que enviamos para a Terra, nossos netos, esses pedaços de nós, serão felizes. Quanto aos outros, devemos enganá-los (id. ibid. p. 18-19) [Grifo nosso].

Importa, desde já, focar os "pedaços de nós" - do filho e do próprio pai Tupã, este último enquanto fonte de até travessuras contra não aparentados. Um exemplar deles é o karai que atribuiu maldade à condição de "um" aos pequenos seres que povoam e padecem a imperfeição da Terra.

Trata-se de condição que é comum, universal ou homogênea; em outras palavras, é uma só em todos os pequenos seres, por força da transitoriedade da existência que, inclusive, cabe ser assemelhável à historicidade em Marx, exceto, obviamente, quanto a dissolvê-la no bojo do materialismo ou da existência autoconstituída de antemão incompatível com o recurso indígena à deidade de Tupã e de seu filho.

Mas, inicialmente ficou dito que é "o pequeno porco selvagem que vai provocar a multiplicação da Terra imperfeita”, assertiva cuja abscôndita mensagem o próprio Clastres parece dela não se aperceber: é a própria natureza que se reproduz e dispensa os guaranis de recompô-la, o que, também inicialmente, fora atribuição propriamente divina.

Assim, enquanto a Terra imperfeita não atingir o tamanho divinamente desejado, o filho de Tupã não será prevenido e os "pedaços de nós" ficarão sem assumir o que neles persiste apenas potencialmente divino. Nesta condição, recorrência das desgraças dos guaranis sempre os fez migrar, em busca da imperfeição da Terra, e impedir que eles (re)produzissem, ao menos isto, esta 
mesma imperfeição, conforme cabe ser interpretado, mediante termos referenciados pelo próprio Clastres (ib., p. 121):

Povo entre todos religioso, através dos séculos presos à sua recusa altaneira de sujeição à terra imperfeita, povo de loucos orgulhosos que se estimava o suficiente para desejar colocar-se na fileira dos divinos, os índios guaranis vagabundavam ainda, outrora, à procura de sua verdadeira terra natal, que eles supunham, que sabiam situada lá longe, do lado do sol nascente, "o lado de nossa face". E muitas vezes chegados lá, nas praias, nas fronteiras da terra má, quase à vista da meta, o mesmo ardil dos deuses, a mesma dor, o mesmo fracasso: obstáculo à eternidade, o mar indo com o sol. (Aspas e grifos no original).

Assim, a situação de povos tais como esses tupis guaranis precisaria ter sido encontrada por europeus outros que aqueles redutores do produzir a trabalho materialmente alienado e humanamente indigno, pois ainda não tinham que produzir de modo objetivamente exposto à falta de limites nas projeções do pensar e nos artificios do agir dos seus chefes.

Todavia, nativos da América Latina, especialmente sul-americanos, têm impedido que feneçam, em outras realidades, propósitos e ações no sentido de prevenirem ostracismo, não somente à utopia, como também à esperança.

Paralelamente, cumpre relevar que tal impedimento tem ocorrido na condição de suplemento cristão-religioso, mediado pela dualidade "inculturação e libertação" (Paleari, 1993, p. 159169) e, por implícito que o ocorra e que o tenha de ser alertado, inclusive por risco de exposição ao ostracismo tal como se expôs a luteranidade antimaterialista de Lange (1903), por força de ainda 
não ser possível ultrapassar alheamento em relação à falta de limites em projeções do pensar e em artifícios do agir, sobremaneira em termos de consumar o "fim" marcusiano da Utopia.

No horizonte categoricamente modal da necessidade, da possibilidade e, inclusive, da virtualidade, de tal consumação, cabe abertura à surpreendente originalidade do pensar religioso junto aos "xamãs guaranis", em razão de atribuir origem divina, ainda que meramente imaginária, à imperfeição da Terra e por maldizer a objetividade desta mesma imperfeição, uma vez que se encontravam como que imersos em fartura natural, ou seja, faltava oportunidade para homens agirem de modo produtivo em contraponto à situação ocupacional junto às mulheres. Estas exerciam, diariamente e durante algum tempo, atividades domesticamente sediadas, enquanto aqueles só efetivamente produziam ao longo de "cerca de dois meses em cada quatro anos", quando lhes cabia "arrotear, por meio de um machado de pedra e com o auxílio do fogo, a superfície necessária" para que elas plantassem, mondassem e colhessem.

Presença de limites ao agir se contrapunha à concernente falta ao pensar que, então, projetava-se no imaginário sobre Tupã e, até mesmo do seu (anônimo) filho, a quem competiria reproduzir tal imperfeição. Assim, reproduzia-se ininterruptamente falta da necessidade, da possibilidade e, sobremaneira, da virtualidade de identificar inequívoco produzir com recompor a imperfeição da Terra.

Trata-se de identificação cuja ausência, junto a até mesmo críticos de conceitos totalizadores e absolutos, resta passível de suspeição quanto a se exporem ao contágio das projeções do pensar sobre o que Dussel (apud Paleari, 1993, p. 160) denomina como "o espaço metafísico ou transontológico".

Diversamente, prevenir tal contágio, cumpre que se o diga, incidiria em objetivar que, em rigor, o dar-se a conhecer da deidade 
aos humanos adentra problema tão somente desta mesma deidade, a menos que os humanos por eles mesmos se ascendam à condição de deidade, restando ao menos curioso que a tanto se arvorem, desde um selvagem sul-americano até as sumidades filosóficas e teológicas do Ocidente de origem greco-europeia, origem que ainda reflete a oposição entre os mundos helênico e bárbaro, para a fragilização do segundo e o empoderamento do primeiro.

A esta altura da abordagem do "unismo condicionado por unicismo", em cuja dialética se colocam as duas soluções mágicas de conquistar, notória e historicamente, poder político e riqueza econômica, ambas enquanto ilimitadas projeções do pensar e irrestritos artificios do agir, cumpre que se adentre a teleologia de como explicar ausência de surpresa a respeito de que virtuoses da religiosidade cristã sejam reduzidas a sempre menos expressivos resquícios, sem que se lhe oponha defesa preventiva contra algo que não seja mais do que eivá-la de "joio" (ilimitação de projeções do pensar e de artificios do agir), enquanto ainda persista imaturo o "trigo" (produção inequívoca e opcional-livremente assumida).

\section{Criteriosidade pura e simples}

Trata-se da possibilidade de existir o que em Abbagnano (2007, p. 259-260) é referenciado como "Uma regra para decidir o que é verdadeiro ou falso, o que se deve fazer ou não etc.".

Ao se ter em conta mera possibilidade de critério, buscase vislumbrar alteridade de significado a respeito de ser utópico suprimir a inexistência de determinado objeto que é imprescindível no sentido de esta mesma supressão se implicar em referência e fundamento. [Nesta busca, corrobora-se a inconformidade de Heidegger (apud Abbagnano, ib., p. 848) com assumir ontológico por ôntico e vice-versa]. 
Assim, referência é vislumbrada de forma ideativa e fundamento de modo material, na perspectiva de recorrer à causalidade ôntico-social de leis cuja concepção procede de determinada categorização ulterior de Lukács $(2003$, p. 20) a respeito do critério marxiano de que o trabalho, na atualidade histórica da sua originária condição de único mediador do intercâmbio orgânico entre natureza e humanidade, cumpriria processar-se de modo coerente - criterioso, para todos os efeitos - com o (natural) metabolismo que é interno à essência do complexo constituído pelo ente humano e pela própria sociedade.

Já este processar-se cumpre coincidir com a necessária e objetiva condição para ter acontecido "o salto filosófico" (ib., p. 20) que corresponde à mediação, através da qual, sujeito e objeto passaram a se colocar enquanto representações de realidades ôntico-coletivamente constituídas.

Por sua vez, a própria coerência cumpre incidir em determinado dever-ser, por frustrante que esta incidência tenha que se impor às vigentes ideologias sobre a origem marxiana da cientificidade que futuramente - cabe que assim se admita - venha a servir para restaurar a originária lei ôntico-coletiva cuja mediação cumpriria prevalecer para ultrapassar divergências de realidades que, já a seu tempo, dificultaram a ninguém mais do que ao próprio Marx (2004, p. 109) atribuir qualificativos ao trabalho.

Por seu turno, estas realidades estão a refletir intensificada indiretitude entre a natureza livre e o metabolismo humano, indiretitude que se faz valer mediante avanço científico-técnico na instrumentalização do que resta denominado como trabalho, resto este a ocorrer intensificadamente mediado por esvaecimento dos limites que a pregressa diretitude lhe facultava deter.

Tal esvaecimento, ao descaracterizar suporte real que faculte à concepção de trabalho chegar a deter limites, urge ser enxergado 
como ilimitações antinômicas entre valor econômico (preço, enquanto "cavalo-de-batalha" para expandir capital-dinheiro e este ser convertido em ilimitada apropriação das fontes de meios de vida) e valor extraeconômico (justiça/dignidade humana).

Tem-se em vista a antinomia que, em Marx (apud Lukács, 2012, p. 419), se encontra suprassumida "em correspondência com a estrutura ontológica [em rigor ôntica] fundamental do ser social", antinomia em cujo âmbito há como vislumbrar ilimitações de objetos ideológicos (valores etc.), em oposição a imprimidas limitações materiais (necessidades econômicas) que têm condicionado o modo imediato como a base vital da humanidade tem que provir da "relação genérica natural" (ib.) entre os gêneros da espécie.

Diversamente, reverter, ou mesmo conter, esvaecimento dos limites para restabelecer coerência mediadora do trabalho, por entre natureza livre e humanidade, pressupõe mudança de processo social.

Por sua vez, esta mudança é referenciada por Tertulian (2010, p. 396) em termos de uma resultante final que o próprio Lukács considera deter "caráter eminentemente casual":

A tese de fundo é que os processos sociais são postos em movimento exclusivamente através dos atos teleológicos dos indivíduos, mas a totalização desses atos numa resultante final tem um caráter eminentemente casual, privado de qualquer caráter finalístico. (Grifo nosso).

Dada esta eminência do caráter casual, juntamente com a condição de o ato teleológico ser restrito propriamente à pessoa, ambas - eminência e condição - tendem a favorecer que seja posto em movimento, com exclusividade, um processo social de 
mudança, pois reúnem requisitos que passam a perfazer criteriosidade no sentido de encontrar poro, fissura, ou mesmo brecha, para conter, quiçá reverter, esvaecimento dos limites que residualmente ainda caracterizam o trabalho na sua mais originária condição de mediador do intercâmbio orgânico entre humanidade e natureza, de modo a voltar a ser coerente - criterioso - com o metabolismo que é interno à condição do ente humano, também ôntica e não pretensamente apenas social.

Assim, ou seja, não por mero acaso, recoloca-se alternatividade de categorização ulterior ao lukacsiano ato teleológico. Trata-se de alternatividade em alcance fundamental e em sentido referencial, de modo e forma que cumpririam ser assumidos até mesmo pelo próprio Lukács (2003, p. 20), caso lhe fosse possível, à época, rever obras anteriormente elaboradas.

Assim fundamental e referencial, a reprodução da espécie humana cumpriria, respectivamente, ser assumida e categorizada. A reprodução sempre ocorreu; e, há de ocorrer, à referência de que a (estrita) idealidade da não ocorrência se implicaria no absurdo da extinção de nada mais do que a própria humanidade. (A propósito de tal implicação e por subentendido que recorrentemente o esteja, o desdém do absurdo em foco sempre coincidiu com a persistência do recurso à indignidade humana no mundo do trabalho).

Cabe, então, consentir que se passe a enxergar condição assumida e sentido categórico em bem determinadas realidades, conforme logo adiante elencadas - ordenadas, em rigor:

\section{$\left.1^{a}\right)$ Interação entre sustentador(es) e prole humana naturalmente ainda autoinsustentável.}

A interação em foco é detentora de causalidade ôntico-coletiva cuja ontologia (representação objetiva) se desvela como que 
vocacionada a adentrar teleologização, não apenas para pensar coibição do esvaecimento dos limites materiais do trabalho, mas também para atualizar o significado da marxiana suprassunção da antinomia entre necessidade econômica e implicações do atendimento desta necessidade.

Adicionalmente àquela coibição e a este significado, trata-se de teleologização especialmente relevante para intensificar qualidade em desenvolvimento humano.

Assim, a representação que é concernente à realidade da interação em apreço passa a deter potencial no sentido de incidir em recurso para assumir determinada práxis educativo-coletiva, esta a se coadunar, em sentido também assim teleológico, com a intensificação da qualidade em desenvolvimento humano e, simultaneamente, com divisar outras realidades às quais correspondam categorias direta e indiretamente conexas àquela desta mesma interação.

Dentre as realidades assim divisadas, distinguem-se outras quatro:

$\left.2^{a}\right)$ A imediatidade da excedência de produção que não pertence à sua própria fonte geradora.

A excedência assim categorizada é imediata porque está sempre presente, pois tem de ficar ineliminavelmente disponível à reprodução humana a se processar de modo estruturalmente ampliado. Já este modo se implica na recorrência de novos indivíduos a serem acrescentados aos dois gêneros da espécie dos quais eles procedem. Todos estes indivíduos detêm organismos em rotineira sustentação.

Porém, os organismos dos novos indivíduos se encontram, inicial e naturalmente, onticamente incapazes de se manterem, de 
modo que os adultos precisam sustentá-los, mediante a geração de pertinentes meios, em excesso relativamente àqueles que seriam gerados na ausência de tal incapacidade.

Esta mesma excedência de produção, a existir de modo sempre imediato, distingue-se, também e especificamente, em razão da sua pertença, uma vez que os concernentes destinatários dependem de atitudes do(s) seu(s) sustentador(es) que, direta ou indiretamente, são presumidos ao dever-ser do modo natural ou objetivo e da forma mínimo-coletivamente justa daquela pertença ser efetivada.

Por sua vez, as condições para aquela dependência e este dever-ser serem efetivados facultam, de modo também conexo às duas anteriores, divisar outra categoria cuja mínimo-coletivamente ôntica materialidade importa à teleologia, ora em composição, para intensificar qualidade em desenvolvimento humano.

$\left.3^{a}\right)$ Distinção entre produzir e apropriar os inelimináveis resultados.

Inequivocação quanto a produzir e a apropriar somente se coloca ao se ter em conta que é imprescindivel ou natural-institucional gerar excedência de produção cujo destinatário não é a fonte da concernente geração, além de que esta mesma geração precisa ocorrer mediante coerência sempre mais indireta com o intercâmbio orgânico entre natureza e metabolismo humano.

Assim, a destinação de tal excedência passa a sugerir critério com necessária e suficiente objetividade para afirmar que a pertinente geração perfaz produção inequívoca, porque o sujeito por ela responsável se limita a apenas gerá-la, enquanto os destinatários somente a apropriam, em acordo com limites que estes sequer têm como fixá-los. (Paralelamente, não cabe relacionar tal destinação 
ao consumo dos meios que foram incorporados aos produtos que perfazem o suporte real desta mesma excedência).

Todavia, impõe-se mediatidade na pertença da excedência em foco junto à fonte da concernente geração cuja parentela, tão mais próxima esta seja (prole naturalmente ainda autoinsustentável), encontra-se exposta a restar relativizada, por conta e risco de aquela pertença lhe ser natural ou objetiva.

Trata-se de relativização que, por rara ou mesmo inoportuna que o seja, emerge sobreposta em situações alternativamente até fatais, a exemplo de secas, enchentes, terremotos, guerras etc. Neste aspecto e apesar de que em tais circunstâncias se torna admissível relativizar tal pertença, cumpre que entre em questão criteriosidade, especialmente em favor de justiça e de ética contra ganância, sobremaneira contra tributos, estes destinados segundo um balanço de justificavas que tem persistido fechado de forma mágica, por força de se implicar em violência primordial para prevenir todas as demais, sem que sequer entrem em questionamento as inter-relações entre aquela primordial e as presumidamente prevenidas.

Esta forma mágica e aquela relativização da pertença da imediatidade da excedência de produção que não pertence à sua própria fonte geradora, mas que se constitui em necessário e suficiente critério para distinguir entre produção e apropriação dos inelimináveis resultados; ambas - magia e relativização - já conformam empecilho, para não dizer impasse, para adentrar "negação da negação", esta compreendida à base da existência de antítese ao antagonismo entre, de uma parte, evolução social, a estar acentuadamente ameaçada por violência potencial e/ou já efetiva, e, de outra, desenvolvimento depuradamente humano à referência e fundamento de limites.

Por sua vez, estes mesmos limites adentram nova categoria, esta em razão de ser depurante de desenvolvimento humano e, por isso, conexa às anteriores (segunda e primeira): 


\section{$\left.4^{a}\right)$ Limites.}

Sustentador(es) de prole naturalmente ainda autoinsustentável se conduze(m) de modo autodelimitativo, ao não apropriar(em) parte dos resultados por ele(s) produzidos, parte esta que é destinada àquela prole de modo objetivamente heterolimitado.

Nesta assertiva constam as duas condições da ocorrência de limites: enquanto modo fisico ou factual em todos os objetos - na prole, taxativamente; e, enquanto eticidade ou dever-ser em todos os sujeitos - no(s) sustentador(es), procedentemente.

$\mathrm{Na}$ primeira destas condições da sua ocorrência, limites perfazem o exterior dos objetos (das realidades já efetivas ou sempre pós-ocorridas) e, por isso, facultam categorizar tais objetos, à base de representações cuja existência reflete o concurso da percepção humana, de forma direta ou mediante instrumentos.

A partir desta primeira condição da existência de limites, infere-se que só é possível definir natureza, matéria ou objetos acessíveis aos sentidos humanos, em razão de que as concernentes realidades ocorrem dentro de limites que lhes perfazem exterioridade. Em rigor, estes limites coincidem com a aparência das coisas enquanto estas têm como se apresentarem à percepção direta ou indireta (instrumentalizada) dos sentidos de quem os constata, observa ou verifica.

$\mathrm{Na}$ segunda destas mesmas condições da sua ocorrência, limites dependem de que os sujeitos se projetem como fontes humanas de realidades cujas existências são ainda meramente potenciais e cuja representatividade precisa ser inferida mediante o modo vazio do que cumpre atender necessidade, verificar possibilidade, realizar alternatividade e incidir em labilidade. Na recorrência do presente histórico dos modos assim vazios das existências potenciais ou das 
potencialidades, limites se encontram interiores, abscônditos e apenas mediatamente inferíveis enquanto extensos e profundos.

Assim apenas inferíveis, conquanto e em rigor inegáveis, tais potencialidades compreendem limites de modo interior, mediante os quais as realidades correspondentes àquelas potencialidades se caracterizam como necessidades a serem atendidas, possibilidades a serem verificadas, alternativas a serem realizadas, ou mesmo labilidades a poderem ou não poderem ocorrer ${ }^{8}$.

Contudo, se limites são externos às realidades sensíveis (produtos provindos do intercâmbio entre natureza e agir humano), mas também internos às realidades asseveradas mediante a inferência do que ainda perfaz vazio, então, existe também incontinuidade por entre exterioridade e interioridade dos limites, a qual coincide com o inequivoco suporte do pensar para que a este se torne possivel interpor-se.

Ainda que se desprezem os teores de ambos os parágrafos logo acima, sobremaneira nos atualmente difusos horizontes do materialismo e do idealismo, o que, apesar de tudo, cumpre ser colocado é que projeções ilimitadas do pensar e artifícios também ilimitados do agir, ambos têm como se confrontarem com as respectivas improcedências.

Entrementes, tais projeções e artifícios continuam a incidir em ideias-força de ideologias que recorrentemente se implicam em "unismo condicionado por unicismo" a usurpar condição de nada mais do que a deidade, por conta de que nunca teria sido "pecado original" entender e assumir (re)compor a imperfeição da

8 Tais entendimentos sobre o modo de existir do vazio - conforme outrora teria sido afirmado por Leucipo (apud Huisman, 2004, p. 594-597) - não divergem de uma concernente ilação à referência de determinada assertiva provinda de Hegel (apud Lukács, 2012, p.45): "Da mesma forma que há uma extensão vazia, há também uma profundidade vazia”. 
Terra à base de limites ônticos para produzir de modo inequivocamente objetivo e de forma coerente com humanidade.

Neste ponto da reflexão sobre limites, urge que seja descortinada a incontinuidade em questão, mediante o concurso da mais decisiva das realidades cujas categorias foram conexamente explicitadas até este ponto.

\section{$\left.5^{a}\right)$ Sentido (do que é) coletivo}

A incontinuidade por entre exterioridade sensível e interioridade inferível de limites coincide com a condição precipuamente ôntica na qual ambas - exterioridade e interioridade - se dão a conhecer e, inusitadamente, passam a oportunizar a potencialização do sentido (do que é) coletivo. Já a constituição deste sentido adentra potencialidade para deflagrar o que Dussel (apud Paleari, 1993, p. 160) aventa nos seguintes termos:"A destruição da filosofia ocidental, desde Parmênides até Heidegger, é a primeira condição de romper com seu caráter absolutizador".

Por sua vez, este sentido cumpre se interpor, enquanto orientação para o pensamento e objetivo para o agir, por entre, de um lado, os limites enquanto exterioridade da produção que é inconfundível com apropriação dos inelimináveis resultados, e, de outro, os limites enquanto interioridade mais extensa e mais profunda do modo ainda vazio da potencialidade de extrapolar aquela interação - esta, enquanto onticamente mínima e teleologicamente viva entre sustentador(es) e prole naturalmente ainda autoinsustentável - para a esfera da sociabilidade humana que, então, também passasse a se tornar mais extensa e profunda.

Trata-se de passagem que sempre foi postergada, desde que emergiu oportunidade de ela começar a ocorrer e, a seguir, ser estendida e intensificada no contexto das aglomerações humanas 
que iniciaram a obtenção de meios de vida, a partir da domesticação de animais selvagens e do cultivo de cereais silvestres.

Conforme exposto por Barraclough (1995, p. 40), registros desta obtenção remontam ao $8^{\circ}$ milênio a.C., sendo o mais antigo localizado na cidade (hoje chamada) Jericó, no vale do Rio Jordão, e a seguir em Çatal Hüyük, em uma encosta úmida de montanha da antiga Anatólia (hoje Turquia). Aquela domesticação e tal cultivo também ocorreram nas encostas dos Montes Taurus e dos Montes Zagros, os quais circundam as planícies da Mesopotâmia. Posteriormente, vieram a ser produzidas nestas planícies até as próprias condições de produzir - umedecimento de solos mediante canais de irrigação.

A incipiente produção que coincidiu com aquela domesticação e aquele cultivo possibilitou, ao longo de milênios, o aparecimento de núcleos urbanos e, a partir destes, intercâmbio de utilidades. Determinados objetos de metais passaram a compor tal intercâmbio, desde o $5^{\circ}$ milênio (id. ib.): "pontas de lança fundida, machados e similares. Armas, símbolos hierárquicos e objetos de culto [...] seguidos mais tarde por artefatos de uso prático".

À base dos teores desta citação, infere-se que produção possibilitou a existência de aglomerações humanas em que religião e violência - esta, possivelmente, provinda da natureza - se fizeram presentes por motivos ainda muito pouco reconhecidos quanto, respectivamente, à transcendência e à materialidade, bem como ao peso das suas influências.

Segundo a mesma fonte (p. 54), por volta de meados do $4^{\circ}$ milênio, alguns dentre aqueles núcleos chegaram a deter $10 \mathrm{mil}$ habitantes, graças não apenas ao desenvolvimento da agricultura, sobremaneira à base de cultivo irrigado, mas também ao concurso das atividades dos mercadores que chegaram a cobrir distâncias entre o Indus e os Bálcãs, por terra e mar. 
Entretanto, agressão à base de conquistas e posterior defesa destas mesmas conquistas passaram a sobrevir. Há registros de que ambas - agressão e defesa - tenham inicialmente ocorrido por volta dos anos 3.100 a.C., no Egito, mediante a subjugação do reino do Baixo Egito pelo reino do Alto Egito (Barraclough, 1995, p. 58-59). Também se encontram registros sobre a usurpação do poder que era exercido em cada cidade-estado da Mesopotâmia meridional, por volta dos anos de 2.300 a.C., por um rei do povo acadiano. Já este reino foi invadido por um povo conhecido por "Gutians" que, por sua vez, foi conquistado por rei sumério, o que implicou uma primeira e outras posteriores e sucessivas conquistas. Já esta recorrência de conquistas não mais cessou, chegando até ao Egito e deste também retornando até (as atuais) Palestina e Síria (id., p. 54-55).

Assim, civilizações surgiram e desapareceram, dentre as quais se destaca aquela que ocorreu por volta de 1450 a.C. (id., p. 66). Trata-se do surgimento e do debacle, inusitadamente intestino e sobremaneira violento, da civilização micênica, cuja expansão ocorreu a partir da península do Peloponeso, no extremo sul da atual Grécia.

A importância histórica deste debacle reside no vazio em que ele resultou e em cuja interioridade surgiu a civilização clássico -helênica. A influência desta civilização perdura até a atualidade, seja na violência da oposição entre agressão e defesa, seja à cata de refúgio ainda utópico. Trata-se de influência que, a partir dos anos 40 d.C., passou a ser mediada por religiosidade de origem inegavelmente diversa das anteriores, à medida que a violência, ao estar historicamente já inevitável, passa a ser objeto de padecimento em vez de ser promovida. Por sua vez, a religiosidade assim mediadora, apesar de ter persistido ainda excessivamente potencial em relação a ser efetiva, tem demarcado, ousada e modestamente, o alcance dito 
Ocidental do processo civilizatório. Deve-se tal anterioridade de potencial, em vez de efetividade da origem diversa de lide com a violência, à recorrente circunstância de que a mediação daquela religiosidade tenha sido relativizada, para não dizer traída, desde a ingerência gnóstica, conforme denúncia de Lange (1903, p. 190):

[...] de la simple y severa disciplina de la Iglesia naciente salieron los elementos jerárquicos; los obispos acapararon las riquezas y llevaron uma vida orgullosa y mundana á la vez que el populacho de las grandes ciudades se enardeció de ódio y fanatismo; se olvidó el socorrer á los pobres, y el rico usurero se mantuvo en possesión de sus rapiñas con el auxilio de la policia y de los tribunales; ...].

Em rigor, tal ingerência reflete conjunção de magia com poder político-econômico ou vice-versa, à conta das ilimitações dos resultados do pensar e do agir. Trata-se de conjunção em cuja vigência, agressão de cunho político-econômico, seguida por defesa de antemão justificada, precisariam persistir as únicas e não utópicas saídas para a humanidade enfrentar os seus históricos percalços. Por seu turno, tais saídas foram seguidas - apesar de seus seguidores estarem expostos à mais decisiva das influências civilizacionais cristãs, aquela de padecer em vez de promover violência - por destacados mágicos, a exemplo de Cesare Borgia (Duca Valentino, cujo lema era "ou César ou nada”), Cortés, Pizarro(s), Frederico II da Prússia, Napoleão e a dupla Hitler/Schlieffen. Em tais casos, a diferença de "não-ser 'o ser" inferida em Dussel (apud Paleari, 1993, p. 160), por inconformidade a objetivar-se enquanto múltiplo, se torna "unista" na imanência "unicista" de "o ser" de Parmênides. 
Prevenir a conjunção em foco já havia sido objeto de ajuizamento atribuído a um precoce teólogo - Hermas - sobre como enxergar sustentadores da comunidade cristã, ainda por volta de 120 d.C., conforme referenciado por Brown (apud Veyne, 1991, p. 249):

[...] o coração dos cristãos influentes está dividido entre as exigências de solidariedade e intercâmbios sinceros entre cristãos e a preocupação com a condução de seus negócios, e, pois, de seus contatos com os amigos pagãos. A opulência de sua casa e o futuro de seus filhos os preocupam. Embora sejam uma perpétua fonte de ansiedade e da tensão inerente aos "corações divididos", Hermas não duvida de que tais homens desempenham um papel crucial numa comunidade cristã próspera: são a madeira seca $e$ sólida ao redor da qual se enrosca a vinha luxuriante de uma comunidade religiosa próspera e bem articulada. (Grifo nosso).

Sabe-se que, posteriormente, recorreu-se ao dízimo, de tradição judaica, para sustentar, em rigor, parte recorrentemente preferencial das comunidades cristãs, o que significou alheamento quanto a transparecer a procedência dos meios materiais a tanto necessários, sobremaneira ao serem recebidos sob a forma de mero dinheiro. Já esse alheamento se tornou historicamente notório ao final do Século XV e início do XVI, especialmente após a descoberta do Novo Mundo e consequente colonização. Sem demora, passou a existir conjunção do padecer violência, simbolizado pela cruz, com o promover violência, mediante apelo à espada. $\mathrm{Na}$ atualidade histórica, assemelhadas conjunções ocorrem com o judaísmo já milenar e com o multissecular islamismo, o primeiro escudado em armas nucleares (ciência) e o segundo em terrorismo 
difuso (ideologia), este a reproduzir, tardiamente, as conquistas dos exércitos árabes enquanto saída para a máxima expansão do Islã.

Assim, refúgio mediado por oposição entre agressão e defesa - esta última, justificada à conta de ser preventiva - nunca se encontrou tão distante de vir a ser utópico para que venha a deixar de ser, também utópica, a constituição do inequívoco sentido do que sempre cumpriu incidir em coletivo humano.

Naquelas mais primitivas aglomerações de agricultores, a coesão entre seus componentes adultos coincidia com presença de religiosidade e a mediação desta dispensava política escudada em violência. A prática desta coesão fundava-se em generosidade a se concretizar à base da dádiva. Na atualidade histórica, esta generosidade está reduzida ao coletivo natural-mínimo da interação entre prole naturalmente ainda autoinsustentável e pertinente(s) sustentador(es). A mera possibilidade de que a fonte de meios a tanto imprescindíveis coincida com não aparentados adentraria realização de objeto ainda utópico.

Entretanto, excedência de produção imediatamente disponibilizada por fonte humana - que a gera sem que lhe pertença - tem sido ampliada para forçosamente constituir tributos e estes, em derradeira instância, têm persistido justificados para remediar violência, sem que se questione a inegável violência de nada mais do que a própria tributação. Historicamente, cumpre que se questione sobre origem outra da tributação, a qual descarte aquelas do saque, da conquista e do butin, uma vez que sempre persistiu ao menos a potencialidade de tal origem estar ininterruptamente restaurada e, por isso, estar justificada a pertinente injustiça, cuja recorrência faculta indagar: por que "desrealizar" esta mesma injustiça não tem precisado incidir em objeto de determinada utopia?

Resposta a esta indagação tem que significar o atendimento da necessidade de virar pelo avesso nada menos do que a própria história 
da civilização, pois esta sempre refletiu efetividade do poder político escudado na violência de conquistar espaço vital para o exercício deste mesmo poder, à base do Estado. Todavia, a necessidade em foco cumpre ser atendida, apesar de que a realização da mais originária e decisiva das injustiças persista a se reproduzir, sempre mais extensa e profundamente, como verdade apenas utopicamente contestável. Em outros termos, inequivoco sentido do que perfaz coletivo precisa se adensar como o avesso histórico da civilização, à medida que não há como este avesso emergir e de se manter por si mesmo, mas há de existir para que seja "desrealizada" a mais originária e crítica das injustiças.

Ao longo do processo civilizatório sempre foi constatável que produzir, desde a domesticação de animais e do cultivo de cereais, vem favorecendo expansão extensa e intensa de aglomerações humanas, de terras agricultáveis inclusive; porém, os beneficiários dos produtos nunca se aperceberam, com a devida suficiência, de que estes mesmos produtos sempre incidem em inelimináveis limites e que, por isso, os resultados dos seus próprios pensamentos e ações tivessem que se coadunar com estes mesmos limites.

Assim, por força da insuficiência de tal percepção, prevaleceu apelo à mais crucial das magias, àquela religiosamente simbolizada em termos de comer "do fruto da árvore, que está no meio do paraíso", cuja versão meramente profana tem como significar a conquista, sempre violenta, dos resultados de inequívoca produção, especialmente dos resultados da produção já reflexa, a começar por aqueles das condições de produzir (a exemplo do próprio saber produzir e dos solos irrigados). Então, os verdadeiros produtores restaram condenados a uma originária e crítica injustiça. Esta, por seu turno, tinha como confrontar eventual referência e fundamento de uma espontânea religiosidade que justificasse coesão daqueles produtores com o concernente coletivo humano, ao passo que a deidade dos conquistadores tinha que prevalecer de forma exclusamente nominalística. 
Tal imposição tem coincidido com ausência de distinção ou falta de objetiva idealidade, coincidência à qual corresponde conjunção das realidades de produzir e de apropriar os inelimináveis e limitados produtos. Já ultrapassagem desta coincidência sempre incidiu em uma crucial necessidade, cujo atendimento tem ocorrido como o mais encoberto aspecto da utopia.

Por força daquele prevalente apelo à mais crucial das magias, distinção para separar, bem como separação para distinguir, entre produção e apropriação dos inelimináveis e limitados produtos, ambas - distinção e separação - somente irão se colocar ao se ter em conta que é imprescindível ou natural-institucional gerar excedência de produção cujo destinatário não é a fonte da concernente geração, além de que esta mesma geração precisa ocorrer mediante coerência sempre mais indireta com o intercâmbio orgânico entre natureza e metabolismo humano.

A coerência em foco urge decorrer da mediação do inequívoco sentido do que perfaz coletivo humano, pois, este e tão somente este sentido perfaz referência (orientação) e fundamento (base real) para que o pensar e o agir do sujeito humano se coadunem com limites para criar projeções e concretizar artifícios, os quais, alternativamente, persistiriam meras potencialidades de tudo o que não tem como emergir e se manter por si mesmo, mas que tem de existir, sob pena de que nunca venha a ser desmascarada a magia e removida a injustiça, nas quais têm incidido o processo civilizatório e a concernente história.

\section{4. "Desrealização" culturalmente mediativa}

Propor "fim" da utopia, sem que concernente "começo" se encontre em questão, é objetivo que ainda se expõe à suspeita de que ambos - "fim" e "começo" - incidam em implicações de 
espontâneo alheamento quanto a apelar à mais crucial das magias e a concretizar a mais drástica das injustiças.

Tal suspeição tem como ser admitida, porque ambos - apelo e concretização - têm incidido, conjuntamente, na condição de fundo para que se insista em explicar os desenvolvimentos humano e material enquanto decorrência, preferencial antes de tudo o mais, de meras conquistas de resultados de anterior e ineliminável produção, mediante agressividade evocada por espontaneidade preventivamente defensiva.

A prevalecer tal explicação, o significado propriamente humano de produzir tenderá a se tornar supérfluo, especialmente porque estaria em inauguração um inovado retorno às condições materiais da situação ainda devoluta e gratuita da natureza originária, retorno cuja efetivação está a ser atribuído ao avanço científico-tecnológico. Entretanto, esta atribuição teria que continuar admitida, a despeito de que aqueles desenvolvimentos tenham persistido meramente adaptativos ao longo de até mesmo milhões de anos, além de que, na futura situação devoluta e gratuita, sequer é vislumbrável ausência de senhorios unicistas dos objetos técnicos.

Aquela suspeição tem como ser reforçada pelos teores da tese de Simondon (2007, p. 171-195), a respeito de que o modo de existir dos objetos técnicos se implica em tecnicidade que emerge em um ponto neutro por entre a magia e a religião, processando-se de forma indutiva e de modo sempre elementar, ou seja, incidindo em objetos menos abrangentes em oposição ao que sucede com totalidade magicamente invasora ou religiosamente incontida.

$\mathrm{Na}$ prevalência deste modo de existir dos objetos técnicos e na perspectiva da "desrealização" culturalmente mediativa ora em abordagem, a tendência do desenvolvimento de tais objetos - a tecnicidade - passa a depender de que aquele ponto neutro se contenha por entre a exterioridade ou explicitude dos limites 
destes mesmos objetos e a interioridade ou a implicitude dos limites que inteiram pertinentes potenciais a ainda serem objetivados. Em outros termos, cumpriria que a tecnicidade incida em mediação, mas sem que sobrevenha à base de falsos princípios (como sujeitos mágicos) ou de impropriedade de objetos (como remates religiosos).

Dada a tendência em foco, a tecnicidade passa a requerer que a incontinuidade por entre exterioridade e interioridade de limites ainda lhe venha a incidir em apoio para os seus (ora promissores) potenciais de indução e de elementaridade.

Resta, então, imprescindível que o "fim" da utopia correspondente a "desrealizar" um inconfesso mistifório de magia e de injustiça - herdado da cultura helênica posterior ao intestino debacle da civilização micênica - seja projetada na perspectiva de um recomeço que se projete a partir da atualidade histórica do processo cultural e civilizatório.

Trata-se de recomeço que, por ora, cumpre ser entrevisto de forma eminentemente cultural e que, para ser apreendido, requer educação de perfil universitário ainda inusitado, ou mais precisamente, perfil de educação do próprio educador, porém nas antípodas das condições de fundo nas quais tinha que operar o pedagogo clássico-antigo. Este contava com objetos de ensino que não se projetavam em razão de autoconvencimento docente a respeito das concernentes justificações, mas se implicavam em sociológica funcionalidade às vantagens da agressão enquanto defesa preventiva que prevalecia em razão de ameaças, não só reciprocamente potencializadas entre os próprios povos helênicos, mas também em franca irrupção a partir do Império Persa.

Para tanto, o caráter propriamente universitário do perfil educativo, ora em projeção, cumpre se referenciar e se fundamentar nas condições de fundo nas quais tem ocorrido o processo cultural e 
civilizatório, ou seja, nas realidades mais gerais ou universais, cujas existências têm como ser representadas mediante concepções de acessibilidade também universal ou generalizável. Em rigor, tais realidades e concernentes representações cumprem incidir em nada mais e nada menos do que o objeto da educação do próprio educador, bem como - o que atualmente já é imprescindível - inteirar uma "economia propedêutica e interdisciplinar", esta a evidenciar-se como "do conhecimento".

É óbvio que tal objeto e o processo educativo que o propague não emergem e não se mantêm por si mesmos, mas que passam a ter que existir, sob pena de que persista postergado o reconhecimento da condição ôntica da incontinuidade por entre exterioridade e interioridade de limites, além de que, por força desta condição, ambos - objeto e educação - venham a servir de suporte à coerência do pensar e do agir com aquelas generalidade e universalidade, tornando-se enfim possível, não só que fique para trás a magia do apelo à falta de limites de projeções do pensar e artifícios do agir, mas também que religiosidade deixe de se expor aos riscos de se imiscuir com magia, por falta de autocrítica quanto a sucumbir a tentações de mistificar, ou mesmo de mistificar-se, ao abranger objetos concebidos ou realizados à base de conteúdos meramente humanos.

Para tanto, recorre-se a quatro, dentre outros eventualmente possíveis, dos princípios nos quais tem incorrido o processo cultural e civilizatório. São princípios que perfazem referência e fundamento, além de comporem a história da humanidade: $\left(1^{\circ}\right)$ o equilíbrio dinâmico-sustentatório de todo organismo, questão radicalmente ôntica; $\left(2^{\circ}\right)$ a propriedade, enquanto o mais socialmente crítico e ainda inescapável dos contraditórios; $\left(3^{\circ}\right)$ a impossibilidade de não existir excedência de produção exteriormente à propriedade da sua própria fonte humana; $\left(4^{\circ}\right)$ a existência 
de antítese ao antagonismo entre a realização ainda utópica da dignidade humana e a já efetiva realização mágica da dominação política e do interesse econômico.

Primeiro: todo organismo perece ao não estar sustentado, mas, na recorrência da sua sustentação ou no seu equilíbrio dinâmicosustentatório, ele prolifera de modo evolutivamente incompatível com a obviedade da sua sustentação material, conquanto e circunstancialmente, esta incompatibilidade não se tenha generalizado. Todavia, não restam dúvidas de que sempre houve riscos de sobrevir esta generalização, pois, em rigor, tem precedido e/ou acompanhado o processo cultural e civilizatório, em estreita correlação com a violência que usualmente se tornou até estrutural ao longo deste processo. Em suma, tal equilíbrio tem incidido na mais decisiva fonte dos problemas que tem caracterizado o avanço deste mesmo processo.

Segundo: a partir dos seus mais remotos precedentes - abrigo, refúgio, vigilância, cercamento, muralhas, defesa e até agressão à conta de esta defesa precisar ser preventiva - a propriedade tem coincidido com o mais vocacionado dos artifícios humanos que servem para relegar a ostracismo o enfrentamento dos problemas historicamente instaurados no processo cultural e civilizatório.

Trata-se de artificio que sempre se implicou, por obscuro que ainda o permaneça, em contraditoriedade acentuadamente mais extensa e profunda, dado que garantir a propriedade mediante oneração do processo produtivo tem desandado na mais original e mais crucial das violências. Já este desandar corresponde à parte dos produtos que acaba destinada a fenômenos que têm emergido por si mesmos, ou seja, magicamente, e não têm tido que existir, além de que a sua constante sustentação sempre coincidiu com o desvio dos meios materiais de fazer emergir e de manter tudo o que perfaz o coletivo de inequívoco sentido. Por seu turno, este desvio 
tem coincidido com inegável inciência sobre a forma indutiva e o modo elementar como a propriedade persiste como a usurpadora do espaço vital da ciência e da prática científica enquanto tecnicidade, ao se instaurar por entre magia e religião e sem que magia sirva para enxergar e religião sirva para prevenir falta de limites nos resultados do agir e do pensar.

Em desfecho, esta persistência tem implicado conjunção de práticas e confusão de ideias, ambas a estender e a aprofundar o mistifório em cuja imanência não há como discernir, entre si, absurdidade e sentido. Então, adentra-se ao que está a ser vivenciado em termos de nada mais nada menos do que sociedade e sem que nem mesmo se vislumbre emergência de inequivocação sobre o sentido do que seja o coletivo humano, ou seja, sobre como "desrealizar" o contraditório em que se constitui a propriedade enquanto historicamente imperativa e essencialmente perversa.

Terceiro: A impossibilidade de não existir excedência de produção exteriormente à propriedade da sua própria fonte humana ocorre em duas circunstâncias.

A primeira destas circunstâncias se dá na interação entre sustentador(es) e prole humana naturalmente ainda autoinsustentável, coincidindo com a própria humanidade em ampliada reprodução, ou seja, incidindo, por si mesma, na evidência do que significa não emergir e não se manter por si próprio, mas ter que existir, em contraponto à absurdidade de a espécie vir a desaparecer. Constitui-se na circunstância mais primordial em que se coloca suficiência de critério para metodicamente separar e, desta forma, ser possível formalizar distinção entre produzir e apropriar os inelimináveis resultados, estes a provirem do pensar e do agir coerentemente com óbvia detenção de limites, ou seja, com onticidade. Efetivamente, quem gera esta excedência limita-se a 
apenas ativamente produzi-la. Mas, quem a apropria sequer ainda tem como saber que o faz, enquanto produzir lhe é naturalmente inacessível.

A segunda circunstância acontece por exposição a desvios enquanto injustiça na concernente destinação, porque o critério - este, quanto a beneficiários não emergirem e não se manterem por si próprios, mas terem que existir - não tem ultrapassado mera espontaneidade no concernente seguimento. Trata-se de exposição que tem ocorrido, não só no âmbito do mais estreito parentesco da filiação natural, como também e sobremaneira, porque o concernente objeto detém natureza especialmente vulnerável à dominação política e ao interesse econômico.

Assim, há necessidade de que a focalizada situação indefesa, devoluta inclusive, dessa mesma excedência venha a se tornar de antemão defesa.

Por sua vez, esta necessidade se constitui em ensejo inusitadamente inspirativo para engendrar e realizar, de forma teleologizada, objetivo no sentido de deflagrar mudança na imanência do pertinente processo social.

Já esta deflagração cumpre ser engendrada na perspectiva de efetivar o potencial de causalidade desse mesmo critério para ser estendido e aprofundado, inclusive por deter uma espécie de vocação para se tornar convincente junto a pessoas que ainda enxerguem abertura, por inicial ou até residual que o seja, para se projetar em acordo com o que em Ricoeur (apud Doron; Parot, 2007, p. 786) coincide com vontade no estrito sentido de volição:

inclui os fenômenos de "desejo" (a execução de uma ação depende de fatores que o agente não pode controlar), de "ordem" (a execução da ação depende de um sujeito cuja autoridade o agente reconhece) e de "intenção volitiva" 
(a execução da ação depende unicamente do agente)". [Grifos no original].

Nesta peculiar perspectiva, coloca-se a necessidade de mudar, antes de tudo o mais, o processo educacional. Trata-se de mudança no sentido de que sua necessidade se torne convincente por força de um determinado e próprio objeto de ensino, este a ser seguido por docentes e operado por instituições cujos dirigentes previnam confusão entre religiosidade e magia, de forma que, apoiados na incontinuidade por entre as respectivas idealizações, promovam desenvolvimentos humano e material.

Quanto aos demais objetos de ensino, a promoção em foco precisa ter em vista que materialidade há de corresponder à interdependência entre ciência e tecnicidade, pois a existência da técnica passou a ser condicionada por aquela da ciência, enquanto humanidade cumpre se referir à coerência entre generidade e exemplaridade dos próprios objetos de ensino.

Em relação à materialidade, cumpre que se recorra, em coerência com a teleologização em foco, à indução e à elementaridade do modo de existir dos objetos técnicos, à medida que, em eles sendo reais, detêm exterioridade de limites, mas, ao incidirem em estritos potenciais, a concernente interioridade de limites seja assumida, tanto em desfavor da magia ilimitavelmente só apropriadora dos resultados da produção, quanto em favor da abertura à religiosidade, desde que esta se desvele coerente com atribuir sentido a produzir de modo inequívoco, ou seja, tão compatível com dignidade humana quão totalizável por inteirar complexidade mediante apoio na incontinuidade, ou seja, na culturalmente mediativa (Pudera!) "santidade de espírito" por entre exterioridade e interioridade de limites.

Quarto: a existência de antítese ao antagonismo entre a realização ainda utópica da dignidade humana e a já efetiva realização 
mágica da dominação política e do interesse econômico, antítese que é vista a partir da convicção de que persiste determinada etnocentria, sob cuja influência, em alcance nacional e também internacional, dominação política é exercida à conta de ilimitada liberdade, ao passo que interesse econômico, em alcance individual e inclusive comum, é assumido à deriva de presumida e também ilimitável inocência.

Trata-se de etnocentria em cuja esfera não se faculta que as instituições sócio-políticas favoreçam, ou mesmo que venham a favorecer, "desrealização" do que magicamente se tornou realidade e que tem servido de apoio para atribuir condição utópica do que alterinamente precisaria ter ocorrido. Por seu turno, o apoio em foco tem servido para explicar as atuais condições em que se processam os desenvolvimentos humano e material, como decorrência, preferencial inclusive, não só de violentas conquistas de resultados de anterior e ineliminável produção propriamente humana, como também de agressão enquanto defesa preventiva espontaneamente praticada.

Entretanto, impõe-se que se afirme a obviedade de que somente pessoas se constituem em fonte procedentemente originária de gestos generosos, estes a se voltarem para vislumbrar e a seguir, indutiva e especificamente, adentrar eventuais poros, brechas e rachaduras em espaços relativamente menos influenciados pela etnocentria em foco.

Chega-se, então, à antítese ao antagonismo entre um desenvolvimento propriamente humano e outro cuja denominação de econômico tem restado tergiversante sobre seu caráter veladamente político. É antítese que coincide com a autoafirmação do indivíduo-sujeito e que se faz presente, à medida que este indivíduo reconhece a excedência de produção como realidade que 
sempre ocorre ou que é impossível de não ocorrer e cuja pertença tem persistido cultural-socialmente indefesa.

Então, esse indivíduo passa a dispor de referência e fundamento para se convencer de que gerar esta excedência perfaz a atividade estritamente singular-pessoal de produzir distintamente de apropriar os inelimináveis resultados, mas que, de outra parte e inevitavelmente, não a gerar implica em substituir generosidade por obrigação, esta a ser impingida a outrem, em vez de assumida à luz de irrecusável autoconvencimento. Paralelamente, passa a associar entre si generosidade e afetuosidade, assim como obrigação e estranheza. Além disso, tende a tomar consciência de que urge assumir determinada paradoxalidade, esta nos precisos sentidos de "opcionalmente ter que" gerar aquela excedência de produção e destiná-la a constituir tudo o que perfaz inequívoco sentido do que é coletivo.

Por sua vez, esta paradoxalidade compreende inegável potencial para se constituir na mais promissora via de autoafirmação do indivíduo-sujeito. Já esta autoafirmação tem como se estender e se aprofundar ao longo da própria ou pessoal história e em conteúdos de desenvolvimento inequivocamente humano. Porém, em busca deste desenvolvimento, precisará valer-se da dialeticidade na qual refúgio e ameaça se opõem, especialmente na circunstância em que espontaneidade (fazer, sem saber o que se faz) tem como ascender à formalidade da consciência (ao saber pertinente ao que se faz). Já assumir essa via de autoafirmação há de pressupor tomada de consciência para prevenir ameaças de que esta mesma via reste fragilizada, por força de que não venha a se desconcentrar a conjunção de dominação política com interesse econômico.

Entretanto, a própria tomada de consciência se arrisca a adentrar extenso e profundo desalento, quando o indivíduo percebe quão também extenso e profundo tem sido tudo o que cumpre ser 
enxergado como obsessão por absurdidade, sobremaneira na esfera do trabalho intelectual que se processe de forma imprecisamente entendida e, nesta forma, se encontre fazer com que proliferem as ideologias.

Por seu turno, esta proliferação significa prestar-se ao ilimitável atendimento de necessidades que são cultural e socialmente criadas, enquanto o pertinente atendimento perfaz trabalho exercido de forma incoerentemente mediada (instrumentalizada) no intercâmbio entre a natureza livre e o metabolismo humano - este último, a incidir na indissociabilidade entre o que é humano e o que é orgânico. Em outros termos, urge que seja reconhecida a potência e a possibilidade de o trabalho intelectual refletir limites nos seus próprios resultados, porém não mais na perspectiva de atender as necessidades que sempre têm sido cultural e socialmente criadas, a começar pela constante recriação do empoderamento político cujo atendimento tem sido inseparável daquele do enriquecimento econômico.

Abusiva ilimitação no atendimento de necessidades assim recriadas explica que insuficiências coletivas têm ocorrido, antes de tudo o mais, à deriva do ideologismo de promover violência, apesar de que a conflituosidade entre os desenvolvimentos econômico e humano cumpre ser confrontada com o que Lukács (2010, p. 87-88) expõe sobre a correlação entre a integração econômica e a formação das nações.

Nas antípodas do ideologismo em foco e em franca insurgência contra a tal conflituosidade, impõe-se que o indivíduo-sujeito se proponha a produzir, modesta e ousadamente, de modo inteirado e de forma coerente com o intercâmbio orgânico entre a natureza livre e o metabolismo pessoal e social, assim como apoiado no modo de existir dos objetos técnicos, à medida que estes também 
inteiram indiretitude deste intercâmbio em bases indutiva e elementarmente limitados.

No sentido de ilustrar tal autoproposição quanto a produzir, conforme o que até este ponto tem sido projetado enquanto "desrealização" culturalmente mediativa, cabe que se busque pertinente inspiração em uma fala de Jesus, de Nazaré, sobre o que cumpre significar, salvo insuficiência exegética para a devida interpretação, o inequívoco produzir na tradução de Figueiredo (1972):

Qual é pois de vós o que tendo um servo ocupado em lavrar, ou em guardar o gado, lhe diga, quando ele se recolhe do campo:Vai já pôr-te à mesa: e que antes lhe não diga: Prepare-me a ceia, e cinge-te, e serve-me, enquanto eu como e bebo, e depois disto comerás tu, e beberás. E quando o servo tenha feito tudo que lhe ordenou, por ventura fica-lhe agradecido? Creio que não. Pois assim também vós, depois de terdes feito tudo o que vos foi mandado, dizei: Somos servos inúteis: fizemos o que devíamos fazer. [Lc: 17, p. 7-10].

O recurso ao termo "vós" ilustra que a fonte da fala não se inclui entre mágicos e mistificadores, mas não assegura, antes o contrário, que seus seguidores ainda não tenham entendido o quanto custa "desrealizar" a condição mágica e mítica, conquanto historicamente não utópica, de confundir entre si apropriação e produção. Aquele "servo" - em rigor, um não-assalariado - é inútil em relação a ele mesmo, pois tem que gerar excedência de produção que não se destina à sua própria fonte. Além disso, se esta inutilidade não for abraçada, a própria religiosidade irá solicitar que o seja por força de não mais adentrar magia e, sim, objetividade. 
Para a inteiração do objeto ainda utópico, é imprescindível que se considere a recorrência da circunstância em que solucionar sempre implicou produzir e este também aquele, apesar de que um e outro já estejam em efetivação há pelo menos uma dúzia de milênios sem que veraz procedência lhes seja reconhecida. Já em conteúdos díspares em relação ao de produzir, apelar à magia perfaz solução a custas de gerar problemas a tanto em quantidade e gravidade até bem mais do que a própria razão o sugira.

Por isso, urge que se considere abrangência de tempo e de espaço, inclusive em sentido procedentemente religioso, para persistir na certeza e na paciência de que não tenham ainda que decorrer outro(s) milênio(s) para que produzir adentre condição comum, generalidade ou universalidade, enquanto solução efetivamente tal e venha a "desrealizar" o que persiste a se constituir, histórica e magicamente, o próprio processo cultural e civilizatório.

\section{Desfecho autoaplicativo}

Ao longo das subunidades anteriores da presente proposição de reavivar determinada índole latino-americana no sentido de persistir aberta ao "fim" da utopia, intentou-se, a tanto e em desfecho, ultrapassar o fim da magia, ou seja, não mais se deter a abarcar totalidade a partir de um apoio pressupostamente exterior a esta e sem questionamento da procedência de tal apoio.

Após este questionamento, é sugerido, ao menos isto, que este mesmo apoio esteja a se constituir em nada mais do que uma recorrente viciosidade de se insistir em explicar os desenvolvimentos humano e material enquanto decorrência, preferencial inclusive, de meras conquistas de resultados de anterior e ineliminável produção, sobremaneira mediante agressão inicialmente praticada de modo espontâneo e, a seguir, à conta de defesa preventiva. 
Em contraponto a tal viciosidade, um conjunto de representações de cinco realidades urge ser reconhecido como obviedade e que lhe seja atribuída, em perspectiva propriamente educacional, a condição de uma "mina de saberes" para constatar necessidades e estas motivarem teleologizações de objetivos no sentido de acelerar mais extensas e profundas mudanças na sociabilidade humana, mudanças que cumprem ser ilustradas, mediante concernente realização educacional. Estas cinco representações foram compreensivamente tratadas na subunidade 3 deste texto, o que, neste desfecho, justifica apenas evocá-las: $\left(1^{a}\right)$ interação entre sustentador(es) e prole naturalmente ainda autoinsustentável; $\left(2^{\mathrm{a}}\right)$ excedência de produção de pertença cultural-socialmente indefesa junto aos destinatários; $\left(3^{\mathrm{a}}\right)$ distinção entre produzir e apropriar os inelimináveis resultados; $\left(4^{\mathrm{a}}\right)$ limites; e, $\left(5^{\mathrm{a}}\right)$ sentido inequívoco do que é coletivo.

Estas representações se constituem em um complexo de saberes sobre os princípios de fundo do avanço do processo cultural e civilizatório ou da história da própria humanidade. Por isso, estes princípios adentram compreensividade que é generalizável, universalizável ou possivelmente comum, tornando-se objeto de uma economia propedêutica e interdisciplinar, assim como de uma educação propriamente universitária, ou mais precisamente, de uma educação dos próprios educadores. É objeto imprescindível ou natural-institucional, pois as implicações de ignorá-lo têm sido fatais à dignidade humana.

Já esta ou aquela educação universitária, ao ser promovida à base de tal compreensividade, há de contar com proposta educacional ainda "sui generis", ao tempo em que adoção e seguimento da condição geral, universal e comum do objeto em proposição, ambos - adoção e seguimento - passam a dispor de instrumentalização não menos inusitada, em que autoaplicação coincida com 
a difusão deste objeto na situação de reciprocidade entre discente e docente.

Paralelamente a esta difusão, cumpre que jamais se perca de vista o alcance emancipatório de uma proposta educacional assim instrumentalizada, de forma que protagonismo estudantil também faça jus a adentrar práxis de teleologização de mudança nas esferas subjetiva e objetiva, o que ocorre mediante pesquisa-ação a ser objeto de experiência na perspectiva de ser inclusiva de sempre mais numerosos pesquisadores. Adota-se esta pesquisa-ação porque seu objeto é proposto para dar conta, no nível da discência, de que os saberes acessados sirvam para intensificar aproximação às futuras realidades ocupacionais, em cuja presença, egressos do processo educacional precisam se valer de orientação e fundamento para visualizarem especificidade de objetos de ocupação inequivocamente produtiva. Peculiarmente, é nesta visualização que futuros egressos precisam de orientação e fundamento para correlacionar violência primordial com magia institucional por detrás de triviais desenvolvimentismos. É nesta correlação que a "bruma" do inimigo de Tupã (Clastres, 1988, p. 118), apresentada acima na subunidade 2 , intenta "tornar inabitável a Terra imperfeita" (tributação, a ser expandida mediante estímulo a lucrar junto à sociedade civil).

Coloca-se, então, o inequívoco sentido do que é coletivo nas prerrogativas do perfil do egresso da educação a ser promovida.

Neste sentido, cumpre ultrapassar espontaneidade e adentrar conscientização sobre vontade humana enquanto "intenção volitiva", pela qual "a execução da ação depende unicamente do agente" (Doron; Parot, 2007, p. 786). Em rigor, chegar a este perfil significa o egresso ter como valer-se de princípios de fundo no enfrentamento das numerosas e diversas situações de vida, nas quais 
urge que ele próprio também se situe na perspectiva de efetivar seus potenciais para realizar-se.

Tais princípios se caracterizam por neles existirem espaço vital para o indivíduo-sujeito que, nesta ou naquela organização, há de inteirar inequívoco sentido do que é coletivo humano.

Para tanto, o egresso em foco cumpre enxergar aspectos em que se patenteie a presença da pessoa (em termos do que seja "mais individual" da situação), da organização (do que seja "mais organizacional") e do coletivo humano (o "mais coletivo"). No seu conjunto, estes três aspectos esgotam a totalidade de toda situação em que a realidade humana se faz influente, de forma que o egresso, ao se dar conta de tais aspectos, passa a deter orientação e fundamento para realizar os seus próprios potenciais, assim que destes se encontre consciente.

Paralelamente a esta realização, tem-se que considerar a questão da liberdade humana. Diz-se questão, porque, em rigor, liberdade se implica em existir oportunidade de errar, falhar ou mesmo transgredir, sobremaneira se magia e, inclusive, religião exerçam influência na determinação do próprio sentido de ela existir. Nos horizontes mais amplos e profundos desta determinação, influência da magia urge ser o quanto possível ao menos relativizada.Todavia, influência de religião tem sido e promete persistir de forma inescapável, porque liberdade sequer se colocaria na ausência de mistério, este inconfundível com um imaginário "além -limites" da própria razão humana, inclusive porque tal ausência se implica em sua própria absurdidade.

Já esta autoimplicação em absurdidade por parte da razão humana, ao coincidir com o desfecho desta controvérsia sobre a utopia, à base de desalheamento educacional à objetividade, há de coincidir com uma nada surpreendente decepção sobre os teores deste mesmo desalheamento e daquela controvérsia. Todavia e ao 
mesmo tempo, há de significar que inequívoco desenvolvimento humano terá que aguardar muitos outros milênios, tal como já os aguardou a produção distinta da apropriação, produção esta enquanto única e inescapável geratriz daquele desenvolvimento.

Por força de tal decepção, os teores dos parágrafos logo acima apresentados neste "desfecho autoaplicativo" não propenderam a explicitamente antecipar o "juízo final” do processo cultural e civilizatório, inclusive porque aperceber-se de tal antecipação incidiria até mesmo em extremada raridade, ainda que lograsse constar inusitadamente explicitada.

Todavia, intentou-se tal antecipação, por velado que isto sequer o precise ser admitido, uma vez que este mesmo juízo passa a ficar disponível à razão humana de forma exclusivamente restrita ao âmbito da subjetividade.

Trata-se de âmbito que teria sido ao menos vislumbrado por Sócrates, não aquele dos diálogos platônicos, mas o outro, de carne e osso, quiçá descendente dos micênios que, exemplarmente, haviam reduzido a cinzas um processo cultural e civilizatório cujas potestades políticas e domínios econômicos não tiveram maneira de se expandir enquanto "exit" sociocultural. Trata-se de expansão em cujos horizontes até mesmo as conquistas científico-tecnológicas de migrar para outros planetas nunca serão admitidas como utópicas, apesar de recaírem na tentação de incidir em oportunidade de arrecadar impostos e realizar lucros e juros. É na inércia desta incidência que a própria globalização está a acontecer na esteira da falta de saída para até mesmo o próprio Planeta persistir habitável. Apelo às instituições, sobremaneira ao Estado, continuará a ser acreditado enquanto única e inevitável viabilização de soluções.

Já à base de desalheamento educacional, urge que se enxergue de modo propedêutico e se conceba de forma interdisciplinar que 
o Estado, enquanto matriz de velhas ou novas outras instituições, houve de inaugurar-se como a mais originária, covarde e insana das violências, ou seja, aquela de usurpar a excedência de produção que se destina a constituir o inequívoco sentido do que é coletivo e, à conta da persistência desta usurpação, aparentar que se justifica, apesar de nunca ter ultrapassado as próprias recaídas na enganação que desanda em todas as demais. Por isso, violência se tornou até mesmo imprescindível e, por isso, ela sempre foi reproduzida enquanto aparente justificativa para a existência de nada mais do que as próprias instituições, a partir daquela do Estado.

Nas antípodas de tal usurpação, urge que aconteça a paradoxalidade do obrigar-se livremente a gerar excedência de produção a ser destinada, mediante justiça a toda prova, ou seja, de modo e forma radicalmente distintos daqueles cuja atribuição provém da mais injusta das pertinentes origens - o Estado. Com efeito, somente a pessoa humana se constitui na origem da justiça cuja atribuição ainda cumpre ser mediada pelo inequívoco sentido do que é coletivo. Já a universalização do acesso a este sentido tem como provir da educação que detenha objeto próprio e que, enfim, aconteça com veraz qualidade e com ético-cientificamente assegurada procedência.

Neste horizonte de uma utopia que precisa ser realidade e da realidade que teria de se tornar utópica, cumpre que se encontre em questão o significado da própria utopia. Já responder a esta questão requer objetividade a toda prova que, entretanto, ainda não depara suficiência de desalheamento educacional para que as novas gerações, ao substituírem as anteriores, reúnam chances para demover os constantes empecilhos que as induzem a reproduzir, mais intensamente inclusive, ilimitações dos resultados do pensar enquanto meras ideologias e do agir enquanto artificios, ambos - ideologias e artificios - voltados para sofismadamente justificar 
instituições que provêm e se mantêm à conta de violência e, por isso mesmo, esta se parece inamovível.

\section{Referências bibliográficas}

ABBAGNANO, Nicolas. Dicionário de filosofia. São Paulo:

Martins Fontes, 2007.

ARISTÓTELES. Política. São Paulo: Martin Claret, 2007.

BARRACLOUGH, Geoffrey. Atlas da História do Mundo. São Paulo: Folha da Manhã, 1995.

BER GAMO, Pedro. Educação universitária: práxis coletiva em busca de veraz qualidade e de precisa cientificidade. Campina Grande, PB: EDUEPB, 2010.

BROWNE, Alfredo Lisboa. Introdução à economia política. Rio de Janeiro: Civilização Brasileira, 1988.

CLASTRES, Pierre. A sociedade contra o Estado. Rio de Janeiro, RJ: Francisco Alves, 1988.

DORON, Roland; PAROT, Francoise. Dicionário de Psicologia. São Paulo: Ática, 2007.

FIGUEIREDO, Antonio Pereira (trad.). Bíblia Sagrada. Rio de Janeiro: BARSA, 1972.

HUISMANN, Denis. Dicionário dos filósofos. São Paulo:

Martins Fontes, 2004. 
KUCZINSKY, Jürgen. Breve historia de la economia: de la comunidad primitiva al capitalismo contemporâneo. Buenos Aires, Platina, 1985.

LANGE, Federico Alberto. Historia del materialismo. Madrid, 2003.

LUCENA, Roberto Marden. Educação superior, trabalho e humanização: mediações políticas e pressupostos institucionais para a análise da produção social e dos impactos do projeto de formação FASB - Barreiras-BA. Campinas, SP. 2015. Tese (doutorado) Universidade Estadual de Campinas, Faculdade de Educação.

LUKÁCS, György. Prefácio (1967). In: Lukács, G. História e consciência de classe: estudos sobre a dialética marxista. São Paulo: Martins Fontes, 2003, p. 1-50.

LUKÁCS, György. Prolegômenos para uma ontologia do ser social. São Paulo: Boitempo, 2010.

LUKÁCS, György. Para uma ontologia do ser social I. São Paulo: Boitempo, 2012.

MARX, Karl. O capital. "Capítulo IV inédito de O Capital, resultados do processo de produção imediata”. 2. Ed. São Paulo: Centauro, 2004.

PALEARI, Giorgio. Religiões do Povo - Um Estudo sobre a inculturação. São Paulo: AM edições, 1993. 
SIMONDON, Gilbert. El modo de existencia de los objetos técnicos. Buenos Aires: Prometeo Libros, 2007.

TERTULIAN, Nicolas. Posfácio. In: Lukács, G. Prolegômenos para uma ontologia do ser social. São Paulo: Boitempo, 2010, p. 383-402.

VEYNE, Paul (Org.). História da vida privada. São Paulo: Companhia das Letras, 1991. 


\section{A VERDADEIRA UTOPIA ${ }^{1}$}

Slavoj Zizek ${ }^{2}$

Para instaurar uma forma diferente de funcionamento do poder, que vá além dos limites da democracia representativa, permanecer fiel à ideia comunista não é suficiente. Devem ser localizados, na realidade histórica, os antagonismos que fazem dessa ideia uma urgência prática. Deve-se, em primeiro lugar, transformar de maneira crítica os aparatos conceituas de Marx. Por causa de sua negligência quanto à dimensão social do a general intellect $^{3}$, Marx não vislumbrou a possibilidade de privatização do

1 Texto traduzido por Maria Beatriz de Medina para a Revista Filosofia Conhecimento Prático, Edição 51, e disponibilizado no site da própria publicação: http://filosofia.uol.com.br/filosofia/ideologia-sabedoria/31/artigo 28143-1.asp

2 Slavoj Žižek (1949) é um filósofo esloveno cujas influências principais são os pensamentos de Karl Marx, Jacques Lacan e Hegel. Atua nos campos da teoria política, análise cultural e cinematográfica e teoria psicanalítica. É professor da Universidade de Liubliana e professor convidado da Universidade de Vermont (EUA).

3 O termo general intellect significa, em linhas gerais, a inteligência social ou coletiva, o trabalho imaterial. De certa forma, se opõe ao conceito de propriedade intelectual individualizada. 
próprio general intellect - é isto que está no coração da batalha pela "propriedade intelectual".

Nisso Antonio Negri está certo: sob esse ponto de vista, a exploração no sentido marxista clássico não é mais possível - e é por isso que ela tem de ser reforçada, cada vez mais, por medidas legais diretas, ou seja, por uma força não econômica. É por isso que hoje a exploração assume cada vez mais a forma de uma renda. Como afirma Carlo Vercellone, o capitalismo pós-industrial é caracterizado pelo "tornar-se renda do lucro". E é por isso que a autoridade direta é necessária. É preciso impor as condições legais (arbitrárias) para que se extraia a renda, condições que não são mais "espontaneamente" geradas pelo mercado.

Talvez aqui resida a "contradição" fundamental do capitalismo "pós-moderno" contemporâneo. Enquanto sua lógica é desreguladora, "antiestatal", nomática/desterritorializante etc., a tendência principal do "tornar-se-renda-do-lucro" assinala um fortalecimento do papel do Estado, cuja função (não somente) reguladora é mais e mais onipresente. Desterritorialização dinâmica coexiste com e se apoia mais e mais em intervenções autoritárias do Estado e seus aparelhos legais (e outros). O que é possível discernir no horizonte do nosso porvir histórico é, assim, uma sociedade em que liberalismo pessoal e hedonismo coexistem com (e são sustentados por) uma complexa rede de mecanismos estatais regulatórios. Longe de desaparecer, o Estado está se fortalecendo.

Em outras palavras, quando, devido ao papel crucial do general intellect (conhecimento e cooperação social) na criação da riqueza, formas de riqueza estão mais e mais "fora de quaisquer proporções com o tempo de trabalho direto envolvido em sua produção", o resultado não é, como Marx parece esperar, a autodissolução do capitalismo, mas a transformação gradual e relativa do lucro gerado pela exploração da força de trabalho em renda apropriada pela 
privatização do general intellect. Tomemos o caso de Bill Gates. Como ele se tornou o homem mais rico do mundo? Sua riqueza não tem nada a ver com os custos de produção dos produtos vendidos pela a Microsoft (pode-se até mesmo argumentar que a Microsoft está pagando a seus trabalhadores intellectuais um salário relativamente alto), isto é, a riqueza de Gates não é resultado de seu sucesso em produzir bons softwares por preços mais baixos do que seus competidores, ou com uma maior "exploração" dos trabalhadores intelectuais con tratados. Fosse esse o caso, a Microsoft já teria ido à falência há muito tempo. As pessoas teriam aderido em massa a programas alternativos e gratuitos, como o a Linux - que, de acordo com especialistas, possui melhor desempenho do que os programas da Microsoft .

Por que, então, milhões de pessoas ainda compram produtos da Microsoft ? Porque a Microsoft se impõe como um padrão quase universal, (quase) monopolizando o mercado, uma espécie de encarnação do general intellect. Gates se tornou o homem mais rico do mundo em algumas décadas apropriando-se da renda cobrada pela permissão, dada a milhões de trabalhadores intelectuais, de participar da forma de general intellect que ele privatizou e controla. É verdade, então, que os trabalhadores intelectuais de hoje não estão mais separados das condições objetivas de seu trabalho (eles possuem seu próprio PC etc.), o que seria, em Marx, a descrição da "alienação" capitalista? Sim, mas, mais fundamentalmente, não. Eles foram mutilados do campo social de seu próprio trabalho, do general intellect - que por sua vez é mediado pelo capital privado.

E o mesmo acontece com os recursos naturais. Sua exploração é uma das maiores fontes de renda hoje em dia, acompanhada pela luta por quem irá controlar essa renda, as populações do Terceiro Mundo ou as corporações ocidentais. A ironia suprema é que, para 
explicar a diferença entre força de trabalho - que, em seu uso, produz mais-valia sobre seu próprio valor - e outras mercadorias - cujo valor é simplesmente consumido em seu uso, sem envolver exploração -, Marx menciona como exemplo de mercadoria "comum" o petróleo, a mesma mercadoria que hoje é a fonte de extraordinários "lucros". Aqui também não faria sentido vincular os aumentos e as quedas do preço do petróleo à exploração do trabalho - o custo de produção é negligenciável, o preço que pagamos pelo petróleo é a renda que pagamos aos proprietários desses recursos por sua escassez e oferta limitada.

\section{Antagonismo e Protagonismo Global}

A única questão verdadeira hoje é: o capitalismo global contém antagonismos fortes o suficiente para impedir sua reprodução indefinida? Existem, penso eu, quatro desses antagonismos: a ameaça iminente de uma catástrofe ecológica, o caráter inapropriado da propriedade privada para designar a chamada "propriedade intelectual”, as implicações socioéticas dos novos desenvolvimentos tecnocientíficos (especialmente na biogenética) e, por último, mas não menos importante, as novas formas de apartheid, os novos muros e as favelas. Há uma diferença qualitativa entre este último aspecto, a lacuna que separa os excluídos dos incluídos, e os outros três, que designam os domínios daquilo que Hardt e Negri chamaram de "comuns", a substância partilhada do ser social cuja privatização é um ato violento a que se deve resistir, igualmente, com meios violentos, se necessário:

- os comuns da cultura, as formas imediatamente socializadas de capital "cognitivo", primariamente a linguagem, nosso meio de comunicação e educação, mas também a infraestrutura comum do transporte público, da eletricidade, dos correios etc. (se o monopólio fosse permitido 
a Bill Gates, chegaríamos à situação absurda em que um único indivíduo seria literalmente dono da tessitura, do software de nossa rede básica de comunicação);

- os comuns da natureza externa ameaçados pela poluição e exploração (do petróleo às florestas e habitats naturais);

- os comuns da natureza interna (a herança biogenética da humanidade): com a nova tecnologia biogenética, a criação do novo homem, no sentido literal de mudar a natureza humana, se torna uma perspectiva realista.

O que todas essas lutas têm em comum é a preocupação com os potenciais destrutivos, inclusive a autoaniquilação da própria humanidade, se fosse dada carta branca à lógica capitalista de enclausuramento desses comuns. Nicholas Stern estava correto em caracterizar a crise ambiental como "o maior fracasso do mercado na história da humanidade” (Revista Time, 24/12/2007). Então, quando Kishan Khoday, um líder de equipe da ONU, escreveu recentemente que "existe um espírito crescente de cidadania ambiental global, um desejo de fazer da mudança do clima uma questão de preocupação comum de toda a humanidade", devese dar toda ênfase nos termos "cidadania global" e "preocupação comum" - a necessidade de estabelecer uma organização e um engajamento plítico globais que, neutralizando e canalizando os mecanismos de mercado, representem uma perspectiva propriamente comunista.

É essa referência aos "comuns" que justifica ressuscitar a palavra comunismo. Ela nos permite ver o "enclausuramento" em marcha dos comuns como um processo de proletarização daqueles que estão, assim, excluídos de sua própria substância. A situação histórica de hoje não só não nos compele a abandonar a noção de proletariado, da posição do proletariado; ao contrário, ela nos compele a radicalizá-la a um nível existencial para além da imaginação 
de Marx. Necessitamos de uma noção mais radical do sujeito proletário, um sujeito reduzido a um ponto evanescente do cogito cartesiano, privado de seu conteúdo substancial.

Por esa razão, a nova política emancipatória não será mais o ato de um agente social particular, mas uma explosiva combinação de diferentes agentes. O que nos une é que, em contraste com a clássica imagem dos proletários que não tem "nada a perder senão seus grilhões", corremos o perigo de perder tudo. A ameaça é que sejamos reduzidos a um sujeito cartesiano abstratamente vazio, desprovido de todos os conteúdos substanciais, desapropriado de substância simbólica e com a base genética manipulada, condenado a vegetar num meio ambiente inabitável. Essa tripla ameaça a totalidade de nosso ser nos torna, de certo modo, todos proletários, reduzidos à "subjetividade sem substância", como Marx afirma nos Grundrisse. O desa o ético-político é reconhecermos a nós mesmos nessa figura - de certa forma, todos nós somos excluídos, tanto da natureza como de nossa própria substância simbólica. Hoje somos todos potencialmente Homo sacer, e a única forma de evitar que nos tornemos um é atuando preventivamente.

Comunismo é hoje não o nome da solução, mas o nome do problema, o problema dos comuns em todas as dimensões - os comuns da natureza como a substância de nossa vida, o problema de nossa biogenética comum, o problema de nossa cultura comum ("propriedade intelectual") e, por último, mas não menos importante, diretamente o problema dos comuns como espaço universal da humanidade, do qual ninguém deveria ser excluído. Isso porque, como colocou Linera, nosso horizonte tem de permanecer comunista - horizonte não como um ideal inacessível, mas um espaço mental no qual nos movemos. Isso é impossível? Nossa resposta deveria ser o paradoxo que retorna ao ponto que começamos: a Soyons realistes, demandons L'impossible. A verdadeira utopia hoje é a de que seremos capazes de resolver nossos problemas com 
transformações modestas no sistema existente. A única opção realista é fazer o que parece impossível nesse sistema.

Lembremos da definição surpreendentemente relevante de Paulo sobre uma luta emancipatória: "Porque não temos que lutar contra a carne e o sangue, mas contra os principados, contra as potestades, contra os príncipes /kosmokratoras/ das trevas deste século, contra as hostes espirituais da maldade, nos lugares celestiais". Ou, traduzindo em nossa linguagem de hoje: "nossa luta não é contra indivíduos corruptos concretos, mas contra todos aqueles no poder em geral, contra sua autoridade, contra a ordem global e a mistificação ideológica que a sustenta”. Se engajar nessa luta signi ca endossar a fórmula de Badiou, mieux vaut un desastre qu'un desètre, melhor assumir o risco e se engajar na fidelidade ao evento-verdade, mesmo que essa fidelidade termine numa catástrofe, do que vegetar na sobrevivência hedonista-utilitarista sem-eventos daquilo que Nietzsche chamou de último homem. O que devemos rejeitar é a ideologia liberal-vitimista que reduz a política a evitar o pior, a renunciar de todos os projetos positivos e perseguir a opção menos ruim - ou, como notou amargamente Arthur Feldmann, o escritor judeu vienense, o preço que usualmente pagamos para sobreviver é a própria vida.

\section{Crença na utopia é ainda a melhor forma de questionar a exclusão social $^{4}$}

Eleger a internet como exemplo democrático é esconder diferenças sociais, institucionais e psicológicas entre as vidas "real" e "virtual".

4 Tradução de Luiz Roberto Mendes Gonçalves. Retirado de: http://cesarkiraly. opsblog.org/2008/06/03/crenca-na-utopia-slavoj-zizek/ 
Um dos grafites mais conhecidos dos muros de Paris em 1968 era: “As estruturas não andam pelas ruas!". Isto é, não se podem explicar as grandes manifestações de estudantes e trabalhadores do Maio de 68 como determinadas pelas mudanças estruturais na sociedade.

Mas, segundo [o psicanalista] Jacques Lacan, foi exatamente isso o que aconteceu em 1968: as estruturas saíram às ruas. Os eventos explosivos visíveis foram, em última instância, o resultado de um desequilíbrio estrutural - a passagem de uma forma de dominação para outra; nos termos de Lacan, do discurso do mestre para o discurso da universidade. Os protestos anticapitalistas dos anos 60 suplementaram a crítica padrão da exploração socioeconômica pelos temas da crítica social: a alienação da vida cotidiana, a "mercadorização" do consumo, a inautenticidade de uma sociedade de massa em que "usamos máscaras" e sofremos opressão sexual e outras etc.

\section{Prazer extremo}

Mas o novo espírito do capitalismo recuperou triunfalmente a retórica anti-hierárquica de 1968, apresentando-se como bem-sucedida revolta libertária contra as organizações sociais opressivas do capitalismo corporativo e do socialismo "realmente existente". O que sobreviveu da libertação sexual dos anos 1960 foi o hedonismo tolerante, facilmente incorporado a nossa ideologia hegemônica: hoje o prazer sexual não apenas é permitido, é ordenado - os indivíduos se sentem culpados quando não podem desfrutá-lo. A tendência às formas radicais de prazer (por meio de experiências sexuais e drogas ou outros meios de indução ao transe) surge em um momento político preciso: quando o "espírito de 68" esgota seus potenciais políticos. Nesse ponto crítico (meados dos anos 70), a única opção restante foi um direto e brutal empurrão para o real, que assumiu três formas principais: a busca por formas 
extremas de prazer sexual, a opção pelo real de uma experiência interior (misticismo oriental) e, finalmente, o terrorismo político de esquerda (Fração do Exército Vermelho na Alemanha, Brigadas Vermelhas na Itália etc.).

O que todas essas opções compartilham é um recuo do engajamento sociopolítico concreto para um contato direto com o real. Lembremos aqui o desafio de Lacan aos estudantes que protestavam: "Como revolucionários, vocês são histéricos que exigem um novo mestre. Vocês vão ganhar um”. E o ganhamos, sob o disfarce do mestre "permissivo" pós-moderno cuja dominação é mais forte por ser menos visível.

Sem dúvida, muitas mudanças positivas acompanharam essa passagem -basta citar as novas liberdades das mulheres e seu acesso a cargos de poder.Entretanto essa passagem para um outro "espírito do capitalismo" foi realmente tudo o que aconteceu nos eventos do Maio de 68, de modo que todo o entusiasmo ébrio de liberdade foi apenas um meio de substituir uma forma de dominação por outra? Muitos sinais indicam que as coisas não são tão simples. Se examinarmos nossa situação com os olhos de 1968, devemos lembrar o verdadeiro legado desse ano: seu núcleo foi uma rejeição ao sistema liberal-capitalista. É fácil zombar da idéia do "fim da história" de Francis Fukuyama, mas hoje a maioria é fukuyamista: o capitalismo liberal-democrático é aceito como a fórmula finalmente encontrada da melhor sociedade possível, e tudo o que se pode fazer é torná-la mais justa, tolerante etc.

\section{Ecologia e apartheid}

Hoje a única verdadeira questão é: nós endossamos essa naturalização do capitalismo ou o capitalismo global de hoje contém antagonismos fortes o suficiente para impedir sua infinita reprodução? Há (pelo menos) quatro desses antagonismos: a sombria 
ameaça da catástrofe ecológica, a inadequação da propriedade privada para a chamada "propriedade intelectual", as implicações socioéticas dos novos avanços tecnocientíficos (especialmente em biogenética) e as novas formas de apartheid, os novos muros e favelas. Os primeiros três antagonismos se referem aos domínios do que Michael Hardt e Toni Negri chamam de "comuns".

Há os "comuns de natureza externa" ameaçados pela poluição e a exploração (do petróleo a florestas e o próprio habitat natural), os "comuns de natureza interna" (o legado biogenético da humanidade) e os "comuns de cultura", as formas imediatamente socializadas de capital "cognitivo", basicamente a língua, nosso meio de educação e comunicação.

A referência a "comuns" justifica a ressurreição da idéia de comunismo: nos permite ver o envolvimento progressivo dos comuns como um processo de proletarização daqueles que são assim excluídos de sua própria substância. No entanto é apenas o antagonismo entre os "incluídos" e os "excluídos" que realmente justifica o termo comunismo. Em diferentes formas de favelas ao redor do mundo, presenciamos o rápido crescimento da população sem o controle do Estado, vivendo em condições meio fora-da-lei, em terrível carência de formas mínimas de auto-organização.

Se a principal tarefa da política emancipatória do século 19 foi romper o monopólio dos liberais burgueses por meio da politização da classe trabalhadora, e se a tarefa do século 20 foi despertar politicamente a imensa população rural da Ásia e da África, a principal tarefa do século 21 é politizar -organizar e disciplinar - as "massas desestruturadas" dos que vivem nas favelas.

Se ignorarmos esse problema dos excluídos, todos os outros antagonismos perdem seu viés subversivo. A ecologia se transforma em um problema de desenvolvimento sustentável, a propriedade intelectual em um complexo desafio jurídico, a biogenética em uma questão ética. 


\section{"Sejamos realistas"}

Sem o antagonismo entre incluídos e excluídos, poderemos nos encontrar em um mundo em que Bill Gates é o principal humanista, lutando contra a pobreza e as doenças, e Rupert Murdoch o maior ambientalista, mobilizando milhões de pessoas por meio de seu império da mídia. O verdadeiro legado de 1968 é melhor resumido na fórmula "soyons realistes, demandons l'impossible!” sejamos realistas, exijamos o impossível!].

A verdadeira utopia é a crença em que o sistema global existente pode se reproduzir indefinidamente. A única maneira de ser verdadeiramente realista é imaginar o que, dentro das coordenadas desse sistema, só pode parecer impossível. 


\section{O REENCANTAMENTO DO MUNDO E ACESSO \\ À INFORMAÇÃO: AS POTENCIALIDADES DAS \\ TeCnologias de InformaÇão e ComunicaÇÃo \\ (TICs) NA CONSTRUÇÃO E REFORÇO DA \\ DEMOCRACIA}

Valdir Jose Morigi ${ }^{1}$

Solange Inês Engelmann ${ }^{2}$

Luis Fernando Herbert Massoni ${ }^{3}$

Ketlen Stueber ${ }^{4}$

\section{Introdução}

Vivemos em um tempo de explosão informacional e, paradoxalmente, o mundo parece dominado pela alienação e o consumismo que dificultam a formação do pensamento crítico. Atualmente, somos bombardeados pela mídia com informações de

1 Professor titular da Fabico/UFRGS. Dr. Em Sociologia pela USP e docente do Programa de Pós-Graduação em Comunicação e Informação da Universidade Federal do Rio Grande do Sul. E-mail:valdir.morigi@gmail.com

2 Doutoranda do Programa de Pós-Graduação em Comunicação e Informação da Universidade Federal do Rio Grande do Sul. Bolsista CAPES. E-mail:solenge103@gmail.com

3 Mestrando em Comunicação e Informação (PPGCOM) pela UFR GS. Bacharel em Biblioteconomia pela UFRGS. Bolsista Capes. E-mail: luisfernandomassoni@gmail.com

4 Mestranda do Programa de Pós-Graduação em Comunicação e Informação da Universidade Federal do Rio Grande do Sul. E-mail: ketistueber@hotmail.com 
que o país passa por uma crise econômica, moral, política, ambiental e de segurança. Soma-se a isso o descrédito da população nas instituições, nos governos, nos partidos políticos e suas lideranças. Parte dessa letargia está associada ao silêncio dos intelectuais e o enfraquecimento da esfera pública, quer seja pela espetacularização, estetização e despolitização da política ou pelos mecanismos que fortalecem o império da intimidade e reduzem a participação dos atores sociais. Essa situação nos leva à falta de perspectiva em relação ao futuro e à incapacidade de criação de novos projetos coletivos para construirmos um mundo melhor.

A cidade é o espaço público da sociabilidade, nela interagimos uns com os outros e com o próprio ambiente, legitimando-a como espaço de interações, lutas, tensões e diálogo. $\mathrm{O}$ medo de sair às ruas cresce entre a população e a sensação de insegurança aumenta. Isso faz com que cada vez menos nos apropriemos dos espaços públicos de convivência, o que enfraquece a sociabilidade e a participação cidadã. Ao mesmo tempo, é nos espaços públicos que manifestamos as insatisfações, reivindicações, paixões e esperanças. Desse modo, o medo de sair às ruas, fruto da insegurança, acarreta na limitação de nossa atuação política, social e cidadã, interferindo no florescimento de novas utopias.

No Brasil, os meios de comunicação estão monopolizados e o controle da informação se restringe às empresas privadas, dificilmente interessadas em fazer da internet, dos usos e apropriações das Tecnologias de Informação e Comunicação (TICs) um espaço para debate e construção cidadã que atue de modo efetivo para romper os silêncios. Além disso, os meios de comunicação de massa se aliam na defesa das grandes corporações e os grupos conservadores que resistem às mudanças sociais através de posições políticas e ideológicas que dificultam a transparência, o acesso e a democratização das informações públicas, tratando os fatos de forma parcial e tendenciosa. 
A legitimidade e a manutenção das sociedades baseadas na democracia deliberativa dependem da construção de espaços públicos participativos, voltados ao embate dialógico de ideias com pretensões distintas entre os cidadãos. Isso tudo com o intuito de formar uma opinião pública crítica e questionadora para a construção de uma comunicação pública participativa, em prol da cidadania e do aprofundamento dos regimes democráticos. Desse modo, a democracia representativa necessita da colaboração, tanto pelos meios tradicionais de comunicação como pelas TICs, na qualificação da participação cidadã e nas mudanças sociais.

$\mathrm{O}$ reencantamento do mundo passa pelo acesso à informação e a possibilidade de sua democratização. Nossa reflexão aborda as potencialidades das TICs na construção do novo espaço público a partir do ciberespaço. As questões que nos mobilizam nesse texto são: Como os usos e apropriações das TICs na vida cotidiana podem reencantar o mundo e criar novas utopias? De que modo elas possibilitam a ampliação da participação dos cidadãos na construção de uma sociedade planetária? A partir da reflexão crítica sobre o tema procuramos responder essas indagações.

\section{Esfera Pública e o Ciberespaço: espaços de democracia e cidadania}

Compreender a esfera pública, sua transformação no decorrer da história, a introdução das TICs e seus usos e apropriações na constituição do ciberespaço, torna-se determinante para ressignificar a construção da democracia, da cidadania e de suas potencialidades no mundo contemporâneo.

Conforme lembra George Yúdice (2015), as esferas públicas se solidificam na Modernidade, final do século XVIII, e se caracterizaram pelo seu aporte físico: as interações sociais entre as pessoas eram diretas e ocorriam em espaços públicos como cafés, salões, 
praças e teatros. Nestes locais ocorriam os diálogos, os debates e as trocas de opiniões entre os cidadãos. $\mathrm{Na}$ atualidade, com as plataformas digitais, a esfera pública converte-se em um espaço virtual em que as interações passam a ser mediadas por informações que circulam em dispositivos tecnológicos.

Perceber o papel dos meios de comunicação na construção e fortalecimento da democracia, formação da opinião pública e dos sistemas democráticos é fundamental. Conforme aponta Norbert Bobbio (1986, p. 84), um dos ideais dos sistemas democráticos é a sua apresentação como o governo do poder visível, “[...] o governo do poder público em público.” Tendo como propósito tornar conhecidas à sociedade as decisões institucionais dos governantes, fazendo do critério da visibilidade um princípio central dos regimes democráticos. Entretanto, o caráter público do poder democrático efetiva-se por meio da publicidade, tornando transparentes para os cidadãos as ações ocultas dos governos. Nesses termos, o avanço de um debate público depende da publicidade sobre os atos do poder e a liberdade de críticas e opiniões, através da constituição de uma opinião pública com papel de mediação social, objetivando a diminuição da invisibilidade e/ou manipulação das informações de interesse coletivo. Dessa forma, a esfera pública não existiria sem os princípios de visibilidade e publicidade, que se traduzem na prática comunicativa da conversação e dos meios de comunicação de massa.

Porém, fundamentada no elemento da conversação ${ }^{5}$, a criação de uma comunicação pública ocorre mediante o desenvolvimento de um público, representando uma forma de sociabilidade

5 A conversação é vista como uma forma de comunicação elementar na formação dos públicos e se encontra ancorada no debate argumentativo e racional de opiniões distintas, fundamental na construção de posicionamentos e mudanças dos 
na democracia. Segundo Gabriel Tarde (1992, p. 29), a psicologia do público compreende-se em "[...] uma coletividade puramente espiritual, como uma disseminação de indivíduos fisicamente separados e cuja coesão é inteiramente mental." Nesse sentido, o público constitui-se como um grupo de indivíduos que partilham entre si um tipo de ligação simbólica, com base em um assunto ou problema. Na medida em que adquirem a capacidade de intervir e influenciar na sociedade, se tornam atores sociais. Portanto, a formação e existência de um público dependem essencialmente de uma conversação, adquirida através do embate argumentativo e dialógico de opiniões distintas. De tal modo que o desempenho do público como ator social coletivo necessita de uma excitação intelectual, baseada na prática reflexiva e comunicacional entre os públicos. Diante disso, a construção de uma comunicação pública participativa e crítica somente se efetiva a partir de uma comunicação de caráter argumentativo entre os públicos, baseada na conversação.

[...] Há um vínculo estreito entre o funcionamento da conversação e as mudanças de opinião, de que dependem as vicissitudes do poder. Onde a opinião muda pouco, lentamente ou permanece quase imutável, as conversações costumam ser raras, tímidas [...]. Onde a opinião é móvel, agitada, onde passa de um extremo a outro, as conversações são frequentes, ousadas, emancipadas [...] (TARDE, 1992, p.134).

mesmos pelos públicos (Tarde, 1992). Nesse sentido que o conceito é abordado no trabalho. 
Portanto, a formação de uma opinião pública crítica depende do incentivo dos governos democráticos e das instituições sociais, no fomento a uma conversação ativa e questionadora, que confira à mesma seu papel de uma comunicação livre e democrática. Diante disso, percebe-se a necessidade de ultrapassar uma visão reificada e/ou naturalizada da esfera pública como algo definitivo e estático. Contrariamente, deve ser encarada como produto de uma formação cultural das sociedades, sendo passível de transformação com base na dialogicidade e na racionalidade.

Dentre as principais dificuldades na construção de uma esfera pública democrática está a falta de condições para a liberdade de participação dos públicos de forma igualitária. Diante disso, compreendemos que o reforço de uma comunicação pública livre e democrática necessita de diversidades de opiniões, da valorização dos indivíduos bem como condições igualitárias para a liberdade de participação entre os diferentes públicos. Esses são requisitos básicos para a promoção de uma esfera pública menos assimétrica, capaz de dar voz aos mais variados sujeitos e grupos sociais, em uma relação dialógica, marcada pelo respeito à opinião e ao saber do outro.

A comunicação pública participativa e crítica que estimula o debate de assuntos de interesse geral, necessita de comunicação e argumentação. Ou seja, somente se torna possível mediante a democratização dos Estados e das instituições sociais nas relações de poder instituídas. Para nos aproximarmos do ideal das democracias deliberativas, torna-se fundamental inserir neste contexto o debate sobre os princípios democráticos de valores, direitos humanos e de cidadania.

A cidadania procura garantir um acesso igualitário aos direitos formais dos cidadãos, contudo, há limitações dos governos democráticos em garantir a igualdade de direitos a todos os indivíduos 
devido às desigualdades sociais inerentes ao sistema capitalista. A busca por cidadania se encontra em constante construção e mutação nas sociedades, a depender do contexto e especificidade de cada Estado-Nação.

A renovação da teoria democrática implica na repolitização global da prática social. Para Boaventura de Souza Santos (1999), politizar é identificar relações de poder e promover formas práticas de transformá-las em relações de autoridade partilhada. Ao ressignificar as relações de poder, desocultar as formas de opressão e dominação, recriar novos meios e oportunidades através das práticas de cidadania, estabelece-se a possibilidade de considerar a dimensão comunitária do espaço público. O espaço político está estruturado em diferentes ambientes, divididos em: espaço doméstico, espaço da produção, espaço mundial e espaço da cidadania (Santos, 1999). Em cada espaço político é preciso desenvolver lutas e abordagens democráticas diferenciadas, segundo suas demandas específicas, a fim de transformar as relações de poder próprias destes espaços em relações de autoridade partilhada.

Essa repolitização pela transmutação das práticas sociais, em um movimento de maior participação dos cidadãos, torna-se necessária a própria alteração de concepção a respeito do que é a cidadania. A mudança no conceito de cidadania implica ir além da reciprocidade e da simetria entre direitos e deveres. De acordo com Santos (1999), para a ressignificação do conceito de cidadania é preciso eliminar os mecanismos de exclusão e combinar formas individuais e coletivas que estão diretamente relacionadas com a teoria da subjetividade.

No contexto contemporâneo, o direito à comunicação e à informação, bem como a democratização das TICs, são fundamentais. Os processos comunicativos e discursivos centrados no diálogo argumentativo em torno de temáticas e problemas de 
interesse público que contemplam visões de mundo e objetivos concorrentes permite constantemente aos cidadãos reavaliar seus posicionamentos em relação às diferenças sociais, políticas e culturais, tornando o ciberespaço ou a esfera pública virtual a Ágora do século XXI.

Mais do que uma criação, a inovação tecnológica possibilitou o nascimento da esfera pública virtual, que permite o debate entre os cidadãos, transformando-se em um centro principal através das redes que interconectam o mundo, interligando empresas, governos, organizações, pessoas de diferentes grupos sociais. Para Maria do Rosário Silva (2010), nossas atividades passam a compor um novo âmbito de articulação em que recebem uma segunda dimensão de existência, que é a dimensão virtual. Tal dimensão gera novas formas de comunicação e interação que promovem a participação e o exercício da cidadania. Além disso, provoca novas exclusões que acrescem mais as desigualdades sociais já existentes em relação ao acesso à informação, à comunicação, às tecnologias e à educação.

Diante da centralidade do ciberespaço, visto como uma esfera pública virtual, percebe-se que os usos e a apropriação das TICs se tornam elementos fundamentais e determinantes, por parte dos sujeitos e grupos sociais contemporâneos, para a criação de práticas mais democráticas. $\mathrm{O}$ acesso dos indivíduos a essas tecnologias adquire papel importante na construção de uma nova cidadania?

O avanço das TICs e seus impactos no espaço virtual ativam as interconexões globais, trazendo questões desafiadoras para a compreensão das novas configurações a partir das dinâmicas que se estabelecem entre as relações internacionais na atualidade. $\mathrm{O}$ mundo passou a interatuar a partir de coordenadas espaciais/temporais cada vez mais flexíveis e descentralizadas a partir das TICs. No entanto, ainda que este fato seja concebido em termos de 
ampliação da democracia - pois seus impactos na política mundial estão cada vez mais interligados - em grande medida, são ignorados. Ou seja, muitas demandas de importância mundial, ainda que tenham adquirido maior visibilidade ao serem compartilhadas por diferentes povos e culturas no contexto da esfera pública virtual, continuam sem resolução e nem sempre são priorizados por parte dos representantes políticos. As questões ambientais (e o descaso a que são submetidas) servem de exemplo para ilustrar tal situação.

$\mathrm{Na}$ perspectiva otimista, o ciberespaço ampliaria a democracia tanto em domínio local, como em domínio global. De acordo com Pierre Lévy (2000), o ciberespaço possibilitaria a expressão e a própria elaboração dos problemas da cidade pelos próprios cidadãos, a auto-organização das comunidades locais e a participação de grupos diretamente afetados pelas decisões nas deliberações, bem como a transparência e avaliação das políticas públicas por parte dos cidadãos. Reforçando essa abordagem, Manuel Castells (2003) afirma que o ciberespaço é uma ágora eletrônica global na qual a diversidade da divergência humana explode em uma cacofonia de sotaques. Conforme o autor, as articulações democráticas seriam atreladas às formas de mobilização política dos diversos movimentos sociais do século XXI, que desempenhariam no espaço virtual global uma nova forma de ativismo político - o ciberativismo.

Nesse contexto, para Castells (2003a, p. 115), alguns movimentos sociais se conformariam através da internet, desenvolvendo ações coletivas e deliberativas com o objetivo de transformar valores e ações, sendo que "[...] o mesmo pode ser dito do movimento ambiental, o movimento das mulheres, vários movimentos pelos direitos humanos, movimentos de identidade étnica, movimentos religiosos, movimentos nacionalistas e dos defensores/proponentes de uma lista infindável de projetos culturais e causas políticas." 
A esse respeito, lembramos que o acesso à informação foi transformado ao longo dos últimos anos, especialmente devido ao surgimento de ferramentas inovadoras da internet. Uma revolução da tecnologia da informação e da comunicação que caracteriza nossa sociedade, responsável pelo informalismo, uma forma de desenvolvimento em que o conhecimento é fonte central de produtividade (CASTELLS, 2006). Ao se estruturar em rede, a sociedade informacional funciona através dos fluxos globais influentes nas relações sociais em todo o globo. Conforme o autor, a internet torna-se o meio de comunicação e de relação essencial que serve de base para a sociedade em rede que vivemos (CASTELLS, 2003b).

Entretanto, tais visões são criticadas e consideradas utópicas por muitos cientistas ${ }^{6}$ em relação à capacidade do ciberespaço representar uma ampliação da democracia. Eles questionam se realmente o ciberespaço seria capaz de promover articulações que possibilitassem a participação política. Ao contrário, apontam numerosas decorrências negativas dos usos da tecnologia para a política atual, em que também identificamos exclusões. Além disso, ao agenciar a virtualização das interações, abranda os vínculos sociais tradicionais (comunitários, familiares, religiosos, etc.).

Bernardo Sorj (2006) questiona o ciberespaço e os usos das TICs ao mencionar a ausência de critérios de qualidade capazes de afiançar o amplo volume de informações fragmentadas e dispersas na rede. Assim, o provável ganho que o ciberespaço proporcionaria em relação ao livre acesso a informações seria amofinado pela impossibilidade de se garantir a confiabilidade e a credibilidade dos autores que se apropriam das informações nele divulgadas para expor suas ideias. Dessa forma, o ciberespaço fracassaria na sua

6 LYON (1998); ZYGMUNT (1999); SUNSTEIN (2001); LEVINE (2004). 
função de possibilitar o acesso democrático à informação, além de prejudicar a apreensão crítica dos cidadãos.

Na concepção de Trejo Delarbre (2009), o espaço virtual vem se transformando em um receptáculo de conteúdos que potencialmente atrapalham as buscas, a aptidão de cotejo, seleção e discernimento dos internautas que navegam pelo ciberespaço. Para o autor, uma maior quantidade de informações não conduz necessariamente ao melhor entendimento ou a uma maior reflexão dos cidadãos das redes, principalmente quando essas informações são compostas por trivialidades e mentiras.

Diante disso, João Pissarra Esteves (2011) procura analisar qual a contribuição da internet, principalmente a versão mais recente da Web 2.0 $0^{7}$, tem a oferecer à democracia. "[...] Uma exploração de hipóteses, possibilidades e alternativas para a construção de uma democracia deliberativa - mais deliberativa - que tem por base o suporte comunicacional hoje oferecido pelas novas tecnologias" (p. 33).

O autor orienta sua pesquisa em um modelo de democracia considerado como um meio de vivência, baseado em valores e normas sociais que possui como condição essencial a cidadania participativa e deliberativa. O propósito é analisar como, mediante o suporte comunicativo, os usos e as apropriações das TICs podem proporcionar mecanismos de colaboração na melhoria da democracia deliberativa, tornado-a mais ampla e eficiente.

Esteves (2011) chama atenção para um significativo aumento na preocupação e consciência social quanto à função das TICs, não somente no aspecto técnico, mas também de caráter ético e moral. Ao mesmo tempo se observa, por parte do autor, o reconhecimento

7 Esta se refere a um conjunto de media com diversas linguagens e discursos, que adquirem significados simbólicos e políticos distintos (ESTEVES, 2011). 
de pontos negativos desses meios, porém, que não o impedem de cultivar uma posição otimista quanto à alteração desse cenário; principalmente, a partir de um alargamento no envolvimento da sociedade civil em vários aspectos e do Estado. $\mathrm{Na}$ sua concepção, essa consciência social se torna mais efetiva com o avanço no acesso de um número mais amplo de cidadãos à internet no mundo, o que representaria um fator importante no rompimento do padrão tradicional de divisão social entre as populações mais ricas e pobres.

Nesse contexto, se considerarmos o caso do Brasil, o número de usuários avançou no último período, mas grande parte da população ainda não possui acesso à internet. Pesquisa do Instituto Brasileiro de Geografia e Estatística (IBGE, 2016) aponta que, em 2014, cerca de 95,4 milhões de brasileiros $(54,4 \%)$ possuíam acesso à internet, atingindo 36,8 milhões dos domicílios. Ao mesmo tempo essas tecnologias, obviamente, atingem preferencialmente os grandes centros urbanos com maior nível de desenvolvimento econômico e renda, se comparado ao espaço rural ${ }^{8}$.

As desigualdades de acesso às tecnológicas, conforme Esteves (2011) compreendem uma nova versão do "digital divide", que evidencia como as diferenças de acesso às tecnologias refletem as reais desigualdades sociais, políticas, econômicas, etc., entre as populações ricas e pobres e os países desenvolvidos e em desenvolvimento. Portanto, ainda que se procure visualizar fatores positivos

8 O uso do computador ainda é muito superior na área urbana, que concentra 51\% dos computadores, enquanto na área rural esse acesso chega somente a $16 \%$ da população. Ao mesmo tempo, nos domicílios em que a renda familiar é menor que um salário mínimo o acesso à internet é de apenas 6\%. Já entre as famílias com rendas superiores a cinco salários mínimos o acesso se entende a 91\% (CGI.BR, 2012). 
nesse contexto, como falar de preocupação social em relação às novas tecnologias no Brasil, se o acesso à internet até 2014, não contemplava 50\% dos domicílios do país (IBGE, 2016).

Entretanto, é importante salientar que as desigualdades tecnológicas não são determinadas pelas TICs, mas pelas relações sociais estabelecidas pelas democracias de massa, em relação a essas tecnologias. Para Esteves (2011, p.36), “[...] não é a internet a grande ameaça à nossa democracia, mas muito mais uma dada ordem social e política - a nossa - que cria, por vezes, grandes limitações à Internet [...] quanto às suas potencialidades e capacidades democráticas."

Portanto, uma ordem digital mais democrática passa pela criação de sistemas sociais e políticos que eliminem as limitações impostas à internet pela ordem atual e desenvolvam mecanismos para a formação de uma opinião pública mais crítica e participativa, que de fato, estimule debates racionais acerca de temas importantes e indispensáveis para a comunicação pública, gerando mudanças significativas na democracia.

Considerando a função do acesso à informação na conversação e no estabelecimento de uma comunicação pública eficaz, com capacidade de influência nas decisões do poder, Esteves (2011, p.37) defende que a internet constitui-se em um instrumento fundamental para a consolidação de uma democracia deliberativa mais participativa, devido ao seu "[...] potencial comunicacional, que resulta das extraordinárias capacidades informacionais da Rede: a grande facilidade de armazenamento, processamento, acesso e difusão de informações [...]." Tal fator vem sendo considerado, principalmente a partir da Web 2.0, devido à maior capacidade de processamento e circulação de informações, ampliando os acessos, a participação e a colaboração em rede. 
A mídia tradicional era calcada na distribuição centralizada de informações, enquanto que o cenário atual favorece o compartilhamento, pois muitos são os autores do que é produzido (CUNHA, 2011). O uso das TICs promove o rompimento de um padrão clássico de comunicação - de um para muitos (emissor - receptor), para de muitos para muitos (inúmeros produtores de conteúdos). Na concepção de Cunha (2011), a "velha mídia" decorria da lógica da sociedade industrial de massa, contexto em que todos tinham os mesmos gostos e compartilhavam das mesmas crenças, ao passo que a "nova mídia" segue a lógica pós-industrial, caracterizada por valores individuais, diferentes estilos de vida e ideologias, com uma oferta maior de escolha. Este fenômeno possibilita a alguns grupos sociais, anteriormente atingidos por uma invisibilidade comunicacional nos meios de comunicação de massa (tradicionais), condições de apresentar suas demandas de comunicação a partir do momento em que obtêm acesso à internet e às tecnologias digitais. Esse contexto insere antigas e novas pautas no âmbito da comunicação pública.

Todavia, como a interação social representa um elemento importante nas democracias deliberativas, percebe-se que uma maior interatividade virtual pode estimular um alargamento na interrelação real dos cidadãos para a democracia. Porém, isso não garante que uma ampliação de interatividade na internet promova uma qualificação real das interações sociais e de uma comunicação pública, já que se observa atualmente a circulação de grandes quantidades de informações superficiais na rede. Estas, em grande parte geram a fragmentação dos assuntos, além de abordar vários temas privados e fofocas, como de interesse público. Portanto, não se pode confundir o aumento do acesso e consumo à informação com a qualificação de uma comunicação pública e fortalecimento da esfera pública, pois geralmente a maior interação comunicativa 
entre os públicos não provoca novos debates ou resulta em uma comunicação pública mais crítica.

Buscando propor soluções a esses problemas, Esteves (2011) defende a criação de um serviço público para a internet, com um conjunto de políticas públicas que estabeleça garantias, proteções e incentivos, promovendo acesso mais equilibrado entre os grupos sociais presentes na sociedade, bem como a diminuição da apropriação individual por alguns segmentos sociais e o estabelecimento de uma rede de comunicação e colaboração de caráter público e não governamental.

Nesse sentido, propõe-se o potencial do uso das TICs no aperfeiçoamento de uma esfera pública que auxilie na qualificação do processo reflexivo e decisório, influenciando politicamente o desenvolvimento de novas posturas e comportamentos democráticos. Porém, as informações divulgadas por meio das tecnologias ainda apresentam algumas debilidades no contexto da democracia deliberativa. Em geral, estas informações não vão além da divulgação de propagandas de ações governamentais, centradas na visibilidade das iniciativas dos grupos no poder e no fortalecimento do papel do Estado, procurando estabelecer uma comunicação direta com a população. A maioria dos Estados também tem adotado uma postura defensiva quanto à internet, centrada na busca pela auto-regulação em detrimento de políticas de incentivo ao avanço da cidadania e de uma comunicação de interesse público (ESTEVES, 2011).

Porém, ainda que tenha possibilitado a reprodução de alguns problemas e debates antigos, é importante registrar que a internet vem gerando condições para um aumento na participação cidadã, especialmente por partes de grupos sociais que antes possuíam inserção mais tímida no embate de ideias na esfera pública. Além disso, ela possibilita a expressão de grupos populares e minorias, 
como as mulheres, gays, negros, movimentos sociais de luta por direitos sociais básicos (moradia, terra, etc.), imigrantes, entre outros.

\section{Acesso à Informação: usos e apropriações das TICs, suas pontecialidades e utopias}

Com o crescimento exponencial dos canais de comunicação, o acesso à informação tornou-se fundamental nas mais diversas esferas da vida pública e privada, perpassando as interações sociais, servindo como fator competitivo para empresas e, também, possibilitando a transparência sobre os gastos do governo. O próprio sistema capitalista vem se rendendo ao papel desempenhado pela informação na sociedade, pois se antes era basicamente regido pelo dinheiro, atualmente presenciamos o capitalismo informacional, contexto em que têm poder aqueles que detém a informação.

Nessa perspectiva, pensar qualquer assunto que diga respeito ao nosso contexto social significa, também, repensar o papel da informação, constantemente presente no cotidiano. Isso porque a informação nos permite acesso a diferentes visões de mundo, tornando-se um elemento com muitas potencialidades na geração de nossos inconformismos e resistências. Conforme Yves Le Coadic (1996), através da informação, se possibilita a apreensão de sentidos ou seres, sendo ela passível de compartilhamento via um sistema de signos. Para Ana Lúcia Castro (2002), o acesso à informação está atrelado à garantia de liberdade, fortalecendo nossa capacidade de escolha. Compreendemos que a informação, ao nos fornecer múltiplas perspectivas sobre um mesmo tema, permite posicionamentos mais críticos e pode nos tornar reflexivos perante a estrutura social vigente. Ou seja: o aceso à informação 
pode ser um elemento-chave na luta pela construção de um ideal e na manutenção de nossas utopias.

Para isso, é preciso compreender os processos de apropriação e significação que dizem respeito ao ato de transmitir e receber informações. A informação é um recurso simbólico, que aglutina sentidos culturais para diferentes grupos e indivíduos (MARTELETO, 2000; 1995) e sua transferência e aquisição também são de ordem simbólica formada a partir do contexto social e da atribuição de sentidos por parte dos indivíduos. Desse modo, o acesso a ela potencializa o entendimento dos acontecimentos sociais e históricos, tornando-se um meio de efetivação da cidadania e propulsora de novas utopias.

Enquanto condição para a sobrevivência, o acervo informacional resiste aos mecanismos de esquecimento e obliteração, de modo a possibilitar reconstruções cognitivas de avaliação e conhecimento da realidade (CASTRO, 2002). Se o contato com o outro, por meio da sociabilidade, não dá conta de nos manter a par das mais diversas visões de mundo, essa função fica a cargo da informação e de seus enquadramentos.

Entretanto, a informação por si só, a partir de uma perspectiva tecnicista, não dá conta dessa trama social na qual a queremos enquadrar. É preciso compreendê-la por meio de uma perspectiva complexa, percebendo que a sua eficácia depende da distribuição no espaço social, das características dos sujeitos coletivos detentores de conhecimento e das tecnologias de informação e comunicação (CASTRO, 2002). Em outras palavras, é preciso o esforço de analisar as práticas de produção, circulação e apropriação da informação na sociedade, tendo em vista a forma como os mais diversos grupos sociais a utilizam no contexto em que nos encontramos.

A sociedade em rede está imersa em uma nova cultura tecnológica e comunicativa, alterando a política, a democracia e a forma 
de pensar (DI FELICE, 2014). Neste contexto, os sujeitos sociais tornam-se ativos, pois deixam de ser meros receptores e passam a ser também emissores de conteúdos informativos. Para Regina Marteleto (2011), informação e comunicação são a energia que move as redes sociais, promovendo a participação dos agentes em plano técnico, cognitivo e político, para a mobilização e participação. Para a autora, a noção de redes sociais é empregada para representar a estrutura social e, quando elas são associadas a ações de mobilização e participação de movimentos sociais, atuam como redes submersas de grupos, o que as configura como pontos de encontro, circuitos de solidariedade que fogem ao padrão de ator coletivo politicamente organizado (MARTELETO, 2011). Assim, configuram-se as redes de relações e os processos comunicativos que fortalecem a cidadania.

A construção das novas utopias está relacionada com o "bem coletivo", que deve se sobressair aos interesses individuais, opondo-se ao que é restrito, ao privado, e, portanto, ao “secreto". Essa é uma condição fundamental para nos transformarmos em uma sociedade mais justa e igualitária. A luta pelo ideal de democracia e suas possíveis utopias ocorre quando os cidadãos se tornam autônomos e protagonistas dos acontecimentos na esfera pública.

No momento em que temos acesso às informações públicas que dizem respeito à gestão dos bens coletivos, é possível compreendermos melhor a forma como nossos impostos arrecadados são aplicados e, desse modo, abre-se também a possibilidade de criticarmos e sugerirmos outros destinos ao dinheiro público. O acesso à informação pública é a melhor forma de fortalecer a confiança coletiva e a responsabilidade social (PLAISANCE, 2011). Ela possibilita a reconfiguração das estruturas da sociedade (BATISTA, 2010a). 
Conforme Carmem Batista (2010b, p. 40), a informação pública:

[...] é um bem público, tangível ou intangível, com forma de expressão gráfica, sonora e/ou iconográfica, que consiste num patrimônio cultural de uso comum da sociedade e de propriedade das entidades/instituições públicas da administração centralizada, das autarquias e das fundações públicas. A informação pública pode ser produzida pela administração pública ou, simplesmente, estar em poder dela, sem o status de sigilo para que esteja disponível ao interesse público/coletivo da sociedade. Quando acessível à sociedade, a informação pública tem o poder de afetar elementos do ambiente, reconfigurando a estrutura social.

De acordo com Batista (2010a), a luta pelo direito à informação perpassa o acesso público, incluindo também a reivindicação contra o segredo de Estado, quando não se trata de informação sigilosa. Para a autora, a disponibilidade da informação pública pressupõe não apenas o acesso físico, mas também a transparência e a compreensão do cidadão a respeito do que é produzido e publicado pelo Estado. Esse pressuposto, segundo Batista (2010a), vai além dos conceitos que consideram os aspectos jurídicos, de legalidade e legitimidade.

Para que cumpra seu papel de transformação social, a informação pública deve necessariamente estar acompanhada de mecanismos que incentivem uma real aproximação com o público e o efetivo entendimento da informação disponibilizada. A linguagem, especialmente, deve ser estar em consonância com o público que acessa a informação, para que seja clara a leitura feita destes documentos. Além disso, a partir do uso das TICs é possível buscar 
tutoriais que ensinem o cidadão a navegar e acessar conteúdos disponibilizados para a plena recuperação e eventual uso da informação desejada.

\section{O Futuro: reencantamento do mundo através das TICs}

As utopias necessitam constantemente de impulsos, paixões e esperanças para fortalecer suas bases filosóficas. Em um processo dinâmico, as trocas dialógicas de saber reinventam-se e abrem espaço para o novo, mas também revisitam o que já foi estabelecido no campo teórico. Neste contexto, é oportuno tencionar um diálogo possível entre pensadores que através de suas inquietudes buscam respostas para desenvolver a sociedade com base nos valores de cidadania, igualdade, liberdade, solidariedade, justiça e democracia.

Conceber as potencialidades que as TICs podem oferecer à sociedade significa também considerar seus usos e apropriações destoantes às propostas de reencantamento e ressignificação que nos propomos nesta reflexão. Milton Santos (2008) afirma que a globalização perversa se baseia na combinação constante entre dinheiro e informação. Ambos formam uma espécie de dupla tirania, pois servem de base para o sistema ideológico, legitimam e conformam as relações sociais e interpessoais por meio da competitividade e da perversidade sistêmica.

As tecnologias de informação e comunnicação utilizadas em função de objetivos privados promovem o aumento da desigualdade social. Ao serem manipuladas, além de confundir e omitir, podem se tornar fragmentos para a sustentação de discursos ideológicos. Promovem retrocesso quanto à noção de bem público e de solidariedade, facilitam e ampliam o papel político das empresas 
na vida social e ao mesmo tempo encolhem as funções sociais e políticas do Estado.

O "reencantamento do mundo" através do acesso à informação e uso das TICs parece ser mais um discurso retórico, o imperativo e a onipresença da informação são indiciosos, pois a informação tem dois rostos: um pelo qual instrui e outro pelo qual convence (SANTOS, 2008). A informação originária de interpretações, subjetividades e intenções pré-estabelecidas no discurso ideológico produz objetos, ou seja, discursos que criam sentidos e comandam comportamentos. De acordo com Santos (2008), estes objetos podem contribuir para a violência econômica do sistema financeiro, principalmente porque os meios de comunicação e informação encontram-se monopolizados.

Haveria outra forma de apropriação das TICs, que nos leve ao reencantamento? Edgar Morin (2010) reflete sobre o assunto partindo dos contextos delineados no século XX, em que o totalitarismo é considerado causa de inúmeras regressões, produto e produtor de guerras e crises (econômicas e democráticas). Estes fatos trouxeram para o campo sociopolítico múltiplos problemas e desafios: a politização do econômico, as responsabilidades de ordem social, cultural, econômica e biológica (ambiental e humana). Para Morin (2010), a relação entre a humanidade e a natureza encontrase permeada por laços de salvaguarda vital e, ao mesmo tempo, por ameaças de destruição da vida, principalmente após a apropriação política do nuclear.

Diante deste cenário, parece não haver mudanças, no entanto a necessidade de impermanência provoca-nos a reacender as utopias e contestar os silêncios. Os argumentos da perspectiva complexa de Morin (2010), acerca da necessidade de estabelecer pontos comuns de ligação entre as pessoas, também estão presentes nos ideais de Santos (2008), ao reivindicar a condição de pensar 
a informação e seus possíveis usos para ressignificar o mundo. Tamanhas responsabilidades concedem à política a missão de " [...] arcar com a multidimensionalidade das realidades antropossociais e assegurar o destino histórico da humanidade." (MORIN, 2010, p. 108). Esta missão precisa acontecer com um duplo vínculo que agregue a todas as coisas uma dimensão política sem reduzirem-se ao político, evitando assim possíveis tendências ao totalitarismo.

Primeiramente, é preciso considerar que o mundo traz em si seus opostos e que há dificuldades em diagnosticar, segundo Morin (2010), o mal ou o perigo principal, assim como a solução ou o bem principal. Diante de grandes e múltiplos desafios, eis a trama do complexo, daquilo que é tecido em conjunto. A pós-modernidade unifica o planeta e, ao mesmo tempo, torna-o ainda mais fragmentado e neste contexto também está inserida a comunicação e a informação: "Tudo comunica, tudo está em relação, tudo permite a compreensão, mas, ao mesmo tempo, a incompreensão aumenta mais" (MORIN, 2010, p. 110). Para o autor, as incertezas e as interdependências têm sido consideradas como obstáculos insuperáveis, mas podem ser aceitas como desafios.

Em Por uma outra Globalização, Milton Santos (2008) reconhece que a unicidade da técnica, a convergência dos momentos e a produção de conhecimento em esfera global são as bases materiais da contemporaneidade. Aponta ainda que tais bases servem de apoio para a globalização perversa que conhecemos, mas ao mesmo tempo projeta nestas bases a expectativa de que podem servir a objetivos contra-hegemônicos se estipulados às finalidades sociais e políticas de emancipação popular.

Para Santos (2008), o progresso da informação e a mistura de saberes e filosofias originadas deste processo colocaram em detrimento o racionalismo e a hegemonia do conhecimento. A diversidade produzida pela população aglomerada em grandes 
centros urbanos é a força motriz capaz de dinamizar a mistura entre pessoas e filosofias. Isto resulta no surgimento de uma universalidade empírica, pois permite conhecer o planeta profundamente. As TIC's podem servir de meios para este processo, pois seu uso viabiliza a criação de saberes e soluções práticas para as demandas sociais.

Para evitar a chamada miopia intelectual (originada nos reducionismos) é preciso pensar " [...] as partes em relação com o todo e o todo em relação com as partes. Tal pensamento evita ao mesmo tempo que se perceba apenas um fragmento fechado de humanidade, esquecendo a mundialidade, e que se perceba apenas uma mundialidade desprovida de complexidades." (Morin, 2010, p.113).

O desafio parece estar em pensar aquilo que não é óbvio, fugir à visão tradicional e rígida. $\mathrm{Na}$ concepção de Michel Maffesoli (2005), precisamos elaborar um saber próximo de seu objeto, em que se possa estabelecer a topografia da incerteza e do imprevisível, da desordem e da efervescência, que englobe o trágico e o não -racional. Trata-se de um saber incontrolável e imprevisível, mas não menos humano, que enlace histórias individuais e coletivas e constitua o ato do conhecimento.

Em 2000, ano da primeira edição da obra Por uma outra globalização, Milton Santos (2008) parece prever as potencialidades das técnicas da informação (termo da época, utilizado pelo autor) ao afirmar que o uso dos computadores exige inteligência. $\mathrm{Ou}$ seja, "[...] é capaz de assegurar a liberação da inventividade e também torná-la efetiva.” (SANTOS, 2008). Percebe-se no discurso do autor a aposta em novos arranjos e criatividade a partir do uso generalizado de computadores e plataformas digitais para contribuírem com a restauração do homem em sua essência.

Neste sentido, Morin (2010) propõe a chamada refundação antropoplanetária, esta, busca pensar os vínculos antropológicos, 
filosóficos e científicos aliados à natureza e ao meio ambiente de maneira interdependente e enraizada. Para Morin (2010, p. 120), "[...] reintroduzir a humanidade no planeta implica introduzir o planeta na política." Esta concepção possibilita a refundação da antropolítica, amparada nos pressupostos interdependentes da diversidade e da singularidade, da ética e da harmonia entre o pensamento racional e o entusiasmo do pensamento apaixonado. Desta forma, se estabelece a busca de uma reconecção com o todo e suas partes, com a unidade e a diversidade. O passado e o presente constituem-se para o sujeito, de um lado através da memória cultural enquanto necessidade identitária; de outro, por meio das descobertas adquiridas durante o processo de desenvolvimento humano.

Qual a relação das tecnologias de informação e comunicação diante destes pressupostos? De que maneira elas podem contribuir nesta complexa trama política e social? Acreditamos que as TICs contribuam enquanto pontos de ligação. Dentre as finalidades de refletir acerca de diferentes pressupostos, destaca-se a necessidade de instaurar possíveis modos de motivar as práticas de democracia. Para Morin (2010, p. 125), este é um dos grandes desafios do século XXI e para isso é preciso "[...] regenerar as cidadanias locais e gerar uma cidadania planetária, ligar nossas diversas pátrias no seio da Terra-Pátria”. As TICs possuem potencial para contribuir com este projeto, pois hoje são instrumentos cada vez mais importantes para aproximar e desenvolver vínculos entre povos e culturas.

Entretanto, como afirma Santos (2008) é preciso politizar as tecnologias diante do impacto sócio-técnico da informação digital. Para o autor, perceber as tecnologias apenas a partir do seu consumo sem considerar a sua produção e inovação é um fetiche. $\mathrm{O}$ acesso à tecnologia promove uma diferença de status, de 
prestígio, portanto, também pode criar uma diferenciação social. Precisamos pensar as TICs a partir da sua produção, apropriações e capacidades de interconexões. Nesses termos, Anthony Giddens (2006) considera que as revoluções das comunicações possibilitam a construção e o desenvolvimento de cidadanias mais ativas e reflexivas do que no passado.

Uma experiência significativa e pioneira acerca do uso da internet, principalmente das redes sociais, por grupos populares para fins políticos (CABRAL FILHO e CARVALHO, 2013), luta por democracia e cidadania, trata-se de um conjunto de protestos que ocorreu entre o norte da África e o Oriente Médio, no fim de 2010 e início de 2011, denominado de "Primavera Árabe". Iniciou-se na região uma onda de protestos contra governos ditatoriais no poder. Uma multidão tomou as ruas pressionando pelo fim das ditaduras e a garantia de direitos sociais negados.

Entre janeiro e outubro de 2011, mobilizações massivas de rua em países Árabes chamaram a atenções do mundo, resultando na queda de Bel Ali, na Tunísia, a derrubada de Hosni Mubarak, no Egito e o linchamento público de Muammar Kadafi, na Líbia, que contou com ampla repercussão da imprensa mundial. Porém, os atos na Líbia tiveram um forte estímulo e apelo da imprensa dos Estados Unidos (DI FÁTIMA, 2012).

Conforme Adilson Cabral Filho e Aline Carvalho (2013), a utilização das redes sociais como uma ferramenta política se inicia com o "Movimento Verde Iraniano", durante as eleições de 2009 no país. Na ocasião, a população utilizou essa tecnologia na tentativa de furar o bloqueio e a censura do governo presente nas mídias tradicionais. Os grupos contrários ao regime também passaram a usar o espaço das redes sociais para contestar o resultado das eleições e denunciar que a manutenção de Mahmuod Ahmadinejad representava fraude eleitoral. O Twitter e o Facebook 
foram utilizados pela população para a divulgação de informações contra-hegemônica ao sistema político e a convocação de protestos e ataques contra páginas do governo.

Diante disso, além da repressão policial às manifestações, que tinham o objetivo de frear as mobilizações e sua repercussão, o governo iraniano censurou a internet, diminuindo a velocidade, bloqueando alguns sites e suspendendo totalmente a conexão por alguns dias. Embora Ahmadinejad tenha permanecido no poder, o engajamento da população no que ficou conhecido como o "Twitter Revolution" demonstrou a potencialidade das redes sociais no estímulo à mobilização da sociedade na busca por mudanças democráticas.

De modo geral, naquele momento as redes sociais tiveram papel central na conscientização e estímulo à população na participação dos protestos e luta por cidadania nesses países. Inicialmente, a maioria das mobilizações massivas havia sido convocada através das redes sociais. Além da função de convocação, a internet desempenhou papel importante na divulgação dos protestos, possibilitando a repercussão internacional e apropriação política da mesma por grupos sociais ausentes nos meios de comunicação de massa, como TV, Rádios e impressos. No entanto, por outro lado, a apropriação das redes sociais na "Primavera Árabe" também chamou atenção de governos e empresas desses países, que passam a considerá-la uma ameaça à estabilidade dos regimes e a fazer uso da internet para mapear os grupos sociais contrários aos regimes ditatoriais vigentes.

Contudo, ainda há concentração dos meios de comunicação na sociedade contemporânea por alguns grupos hegemônicos, que de modo geral ainda dominam as TICs, bem como os vários limites que prejudicam os governos democráticos na formação de um espaço público fortalecido e na participação da sociedade civil 
na formação de uma opinião pública crítica. Torna-se fundamental a adoção de políticas que transbordem as fronteiras dos estados nacionais para auxiliar na resolução dessas questões. Exemplo é o estabelecimento de medidas internacionais de respeito à Declaração Universal dos Direitos Humanos (ONU, 1998), que assegurem direitos civis e direitos individuais, e respeito em relação a acordos internacionais na área de meio ambiente, clima, desenvolvimento e tecnologia, entre outros. Portanto, para o fortalecimento da democracia, necessita-se extrapolar as fronteiras do Estado-Nação (GIDDENS, 2006) e criar políticas transnacionais de proteção aos direitos individuais que auxiliem na construção de um sistema democrático para o exercício da cidadania e emancipação social global.

A era da globalização precisa oferecer uma resposta global. O aprofundamento do sistema democrático depende da viabilização da democratização da democracia, ou seja, o alargamento dos sistemas democráticos necessita de um processo de transnacionalização da democracia. Ou seja, com a operação de uma democratização interna por dentro da nação e externa a um nível global que transborde o território do Estado-Nação (GIDDENS, 2006).

Essa democratização se torna necessária, pois as antigas posturas dos governos não funcionam de forma eficiente no contexto de uma sociedade onde os cidadãos e governos passam a ter acesso aos mesmos meios de informação, principalmente com a internet, que viabiliza um processo de globalização de informação em nível planetário. Diante disso, Giddens (2006) considera que a democratização dos sistemas democráticos precisa ser apropriada de formas diversas e distintas em cada país, respeitando o desenvolvimento histórico de cada nação. São elas a adoção de medidas de combate à corrupção em todos os níveis, reformas 
constitucionais, maior transparência na política, bem como a utilização de instrumentos alternativos, como júris populares e referendos, que podem gerar complementos importantes na democracia. Não estando nenhum país livre dessa necessidade, independente de possuir sistemas democráticos mais avançados.

Isto posto, a democratização da democracia necessita ainda de estímulo ao avanço de uma cultura cívica. "A construção da democracia das emoções é um dos aspectos da cultura cívica progressiva. A sociedade civil é o fórum onde as atitudes democráticas, incluindo a tolerância, têm de ser cultivadas." (GIDDENS, 2006, p.77). Portanto, o cultivo da pluralidade de ideias e opiniões na sociedade depende do fortalecimento de outros setores, que precisam ampliar seu espaço restrito ao Estado e o mercado (setor público e privado), possibilitando a inclusão da sociedade civil, composta pela família e outras instituições sem caráter econômico, procurando assim efetivar uma maior participação nos sistemas democráticos.

Já a construção de uma hegemonia a partir do pensamento de Gramsci (ANDERSON, 1986) se refere à conquista do consenso e liderança cultural, política e ideológica de uma classe sobre a outra. A direção de uma classe ou de um bloco histórico não dependente somente das forças materiais de coerção do Estado, mas da construção de instrumentos de debate e persuasão em torno das questões sociais, através da sociedade civil, ou seja, no plano das ideias. Deste modo, a formação de um consenso contra -hegemônico depende da disputa dos instrumentos de formação de consenso, como a imprensa, os partidos políticos, sindicatos, entre outras instituições influentes. O controle desses órgãos pela classe dominante impede a participação dos segmentos sociais populares, como a classe trabalhadora. 
Conforme Perry Anderson (1986), o conceito de hegemonia em Gramsci demonstra a importância dos meios de comunicação de massa no processo de criação de uma esfera pública forte, com uma participação crítica da sociedade civil no debate de ideias e nos rumos dos sistemas democráticos, no qual atualmente se torna necessário incluir o contemporâneo desenvolvimento da internet. Esses canais atuam de modo privilegiado na produção e distribuição de conteúdo, podendo exercer influência nas relações sociais, culturais e políticas.

Giddens (2006) conclui que a busca de uma democracia equilibrada necessita da operacionalização de um tripé, atuando de modo sincronizado, composto pelo Governo, a economia e a sociedade civil, uma vez que uma das partes não pode dominar as demais. Nesse sentido, o autor considera que a televisão e outros meios, ao transformar a política em instrumento vulgar e personalizado, provoca a destruição do próprio espaço público de debate criado pelo mesmo meio. Contrariamente, a sociedade global de informação representaria um importante espaço de democratização.

Partindo do entendimento de que o desenvolvimento das TICs, responsável pela criação do ciberespaço, torna o mesmo em uma esfera pública virtual de contexto globalizado, considera-se possível conceber a potencialidade desse ambiente como um espaço público plural e crítico, podendo se tornar uma linha de transmissão na construção e difusão de práticas e valores da democracia, à medida que a distribuição de informação, apropriação e os usos dessas tecnologias também sejam regulamentados de modo democrático, eliminando os abusos e o conjunto de desigualdades sociais da contemporaneidade, e promovendo o respeito aos preceitos éticos da informação e comunicação. 


\section{Considerações Finais}

O uso e apropriações das TICs como ferramentas de mediação das informações e de visibilidade, de crítica da realidade e de reivindicações dos direitos parece ter se ampliado. Esse potencial revolucionário é devido à quebra do antigo modelo de comunicação, fundamentalmente marcado pela transmissão de informações a partir de um centro (emissor) para a periferia (receptor). Nesse processo, ao mesmo tempo em que o acesso à informação é facilitado, também é possibilitado o acesso à produção da informação, uma vez que a nova forma de interação social permite que diversos sejam os agentes produtores de informação.

A formação de uma comunicação pública crítica e livre depende da conversação e de uma performática intelectual dos públicos no debate dialógico entre posições concorrentes, transformando o público em ator social coletivo. Porém, percebe-se que atualmente a formação de uma esfera pública questionadora e crítica se encontra ausente, o que contribui com a tentativa de massificação e instrumentalização da opinião pública e busca de legitimidade por parte dos Estados e governos descomprometidos com a democracia, resignados a transferir as riquezas públicas para o sistema privado.

Nesse sentido, mesmo com as limitações impostas pelas desigualdades sociais, políticas e econômicas, devido à potencialidade de acesso e armazenamento de informações, compreendemos que as TICs podem oferecer uma contribuição importante para a democracia deliberativa, auxiliar na formação de uma opinião pública crítica e influente, bem como na maior participação cidadã. Porém, percebemos que o crescimento do acesso à informação, a partir das TICs, não garantem maior participação dos cidadãos e uma melhor comunicação pública nos processos democráticos. 
Isto somente será possível com transformações políticas e sociais estruturais que ultrapassem as debilidades de usos e acessos às tecnologias criadas por esses sistemas. O desafio dos governos democráticos está em alterar as relações sociais e políticas através dos princípios de cidadania e transparência, aproveitando o potencial das TICs na construção de uma esfera pública eficiente, com capacidade de influenciar politicamente os processos deliberativos.

Compreende-se que a transnacionalização dos sistemas democráticos e a construção de uma cidadania global somente será possível a partir de uma efetiva democratização dos meios de comunicação e construção de uma esfera pública virtual, que contemple novas práticas democráticas na luta por cidadania. A transparência no acesso às informações por meio de plataformas digitais auxilia na formação de uma comunicação pública crítica, uma vez que dá ao cidadão a oportunidade de checar de que modo, por exemplo, o dinheiro público é empregado. Esse tipo de prática facilita o controle dos gastos públicos por parte do cidadão, que de qualquer lugar onde estiver pode acessar essas informações, promovendo o sentimento de pertencimento e responsabilidade frente aos recursos públicos. Canais de comunicação como essas plataformas, que apresentam de forma detalhada os gastos públicos, possibilitam também que os cidadãos possam distinguir os gastos e investimentos feitos em nível federal, estadual e municipal, facilitando a identificação de possíveis desvios de dinheiro público por parte de qualquer uma dessas esferas políticas.

Como alerta Santos (2008), é preciso analisar as tecnologias a partir do ponto de vista da politização, procurando compreender que estas se encontram inseridas ao sistema capitalista, que é permeado por um conjunto de desigualdades sociais que afetam o uso e a distribuição desses meios, bem como o acesso à informação. Desse modo, necessita-se analisar as TICs não somente nas suas 
formas de consumo, ma s conjuntamente com o seu funcionamento no sistema de produção, usos e interconexões possíveis, no âmbito da construção da democracia e da cidadania.

Sabemos o quanto os meios de comunicação são capazes de influenciar culturas e comportamentos por meio dos usos e apropriações de diferentes elementos simbólicos. A construção de conteúdos solidários e que promovam a cidadania são praticados no ciberespaço e em algumas mídias tradicionais, mas ainda de modo insuficiente. Torna-se inquestionável que os meios de comunicação sejam capazes de produzir os conteúdos das informações de maneira autônoma, sem que sejam regidos pela lógica do mercado.

Para isto, além da democratização dos meios - com a eliminação dos oligopólios das empresas de comunicação e construção de um sistema de comunicação público e democrático no âmbito da imprensa tradicionais e das TICs -, é preciso apostar em abordagens e trocas informacionais que valorizem a ética e desenvolvam estratégias de comunicação dialógica e de respeito ao Outro, ao diferente. É uma reforma lenta, pois busca alterar as estruturas culturais e sociais em que os indivíduos estão inseridos e requer esforço mútuo entre os meios de comunicação e os atores sociais para a produção e disseminação de conteúdos que promovam a solidariedade e a cidadania.

Refletir acerca do reencantamento a partir das TICs, acreditar em suas possibilidades, por mais utópicas que possam parecer, significa reivindicar seus aspectos práticos e efetivos. Alguns parecem mais dificeis e desafiadores que outros, no entanto, todos são de inquestionável importância. Ou seja, a regulação dos meios de comunicação e informação, a transparência no acesso às informações públicas e até mesmo o investimento na mudança de paradigmas culturais e éticos que envolvam as interações humanas e a maneira de se comunicar, são formas de tornar as TICs e o 
ciberespaço em espaços de sociabilidade voltados a construção e reforço da democracia e à cidadania planetária.

\section{Referências}

ANDERSON, Perry. As antinomias de Antônio Gramsci. São Paulo: Joruês, 1986.

BATISTA, Carmem Lúcia. As dimensões da informação pública: transparência, acesso e comunicação. TransInformação, Campinas, v. 22, n. 3, p. 225-231, set./dez. 2010a.

BATISTA, Carmem Lúcia. Informação pública: entre o acesso e a apropriação social. 2010. 202 f. Dissertação (Mestrado em Ciência da Informação) - Escola de Comunicações e Artes, Universidade de São Paulo, São Paulo, 2010b.

BOBBIO, Norberto. O futuro da democracia: uma defesa das regras do jogo. 9. ed. Rio de Janeiro: Paz e Terra, 1986.

CABRAL FILHO, Adilson Vaz; CARVALHO Aline. Da "alterglobalização" à "indignação": reconstruindo as redes sociais no início do século XXI. Revista Acadêmica de La Federación Latinoamericana de Facultades de Comunicación Social. ed. 86. fev/jul, 2013. Disponível em: <www.dialogosfelafacs.net/ da-alterglobalizacao-a-indignacao-reconstruindo-as-redes-sociaisno-inicio-do-seculo-xxi/>. Acesso em: 10 abr. 2016.

CASTELLS, Manuel. A galáxia da internet: reflexões sobre a internet, os negócios e a sociedade. Rio de Janeiro: Jorge Zahar Editor, 2003a. 
CASTELLS, Manuel. Internet e sociedade em rede. In: MORAES, Denis de (Org.) Por uma outra comunicação: mídia, mundialização cultural e poder. Rio de Janeiro: Record, 2003b, p. 255-288.

CASTELLS, Manuel. A sociedade em rede. 9. ed. São Paulo: Paz e Terra, 2006.

CASTRO, Ana Lúcia Siaines de. O valor da informação: um desafio permanente. DataGramaZero: Revista de Ciência da Informação, Rio de Janeiro, v. 3, n. 3, jun. 2002.

COMitê GeStOR DA INTERnET NO BRASIL. Pesquisa sobre o uso das tecnologias de informação e comunicação no Brasil:TIC Domicílios e TIC Empresas 2011. São Paulo, 2012. Disponível em: <www.op.ceptro.br/cgi-bin/cetic/tic-domicilios-e -empresas-2011.pdf>. Acesso em: 10 mar. 2016.

CUNHA, Mágda Rodrigues da. A memória na era da reconexão e do esquecimento. Em Questão, Porto Alegre, v. 17, n. 2, p. 101-115, jul./dez. 2011.

DI FÁTIMA, B. Primavera Àrabe: vigilância e controle na sociedade da informação. Biblioteca on-line de Ciências da Comunicação. 2012. Disponível em: <www.bocc.ubi.pt/pag/fatima-branco-primavera-arabe-vigilancia-e-controle.pdf $>$. Acesso em: 08 abr. 2016.

DI FELICE, Massimo. Network society (Sociedade em rede): da esfera pública para a conectividade. In: MARCHIORI, Marlene (Org.). Sociedade, comunidade e redes. São Caetano do Sul: Difusão; Rio de Janeiro: Editora Senac Rio de Janeiro, 2014. 
ESTEVES, João Pissarra. Novos media e deliberação: sobre redes, tecnologia, informação e comunicação. Revista Media \& Jornalismo, v. 18, n. 10, 2011.

GIDDENS. Anthony. O mundo na era da globalização. 2. ed. Lisboa: Presença, 2006.

Instituto Brasileiro de Geografia e Estatística (IBGE). PNAD TIC: pela primeira vez celulares superaram computadores no acesso domiciliar à internet. Sala de Imprensa, 06 abr. 2016. Disponível em: <http://saladeimprensa.ibge.gov.br/noticias. $\mathrm{html}$ ?view $=$ noticia\&id $=1 \&$ idnoticia $=3133 \& \mathrm{busca}=1 \& \mathrm{t}=$ pnad tic-2014-pela-primeira-vez-celulares-superaram-microcomputadores-acesso-domiciliar-internet>. Acesso em 08 abr. 2016.

LE COADIC,Yves François. A Ciência da Informação. Brasília, DF: Briquet de Lemos, 1996.

LÉVY, Pierre. Cibercultura. 2. ed. São Paulo: Ed. 34, 2000.

MAFFESOLI, Michel. Elogio da Razão Sensível. 3. ed. Petrópolis:Vozes, 2005.

MARTELETO, Regina Maria. Cultura, educação, distribuição social dos bens simbólicos e excedente informacional. Informare: Cad. Prog. Pós-Grad. Ci. Inf., Rio de Janeiro, v. 1, n. 2, p. 11-23, jul./dez. 1995.

MARTELETO, Regina Maria. Redes e configurações de comunicação e informação: construindo um modelo interpretativo de análise para estudo da questão do conhecimento na sociedade. 
Investigatión Bibliotecológica, México, v. 14, n. 29, p. 69 - 94, jul./dic. 2000 .

MARTELETO, Regina Maria. Redes sociais: formas de participação e de informação. In: GÓMEZ, Maria Nélida Gonzáles de; LIMA, Clóvis Ricardo Montenegro de (Org.). Informação e democracia: a reflexão contemporânea da ética e da política. Brasília, DF: Ibict, 2011. p. 173-183.

Morin, Edgar. Em busca dos fundamentos perdidos: textos sobre o Marxismo. 2.ed. Porto Alegre: Sulina, 2010.

PLAISANCE, Patrick Lee. Ética na comunicação: princípios para uma prática responsável. Porto Alegre:Artmed, 2011.

SANTOS, Boaventura de Souza. Pela mão de Alice: o social e o político na pós-modernidade. 5.ed. São Paulo: Cortez, 1999.

SANTOS, Milton. Por uma outra globalização: do pensamento único à consciência universal. 15. ed. Rio de Janeiro: Record, 2008.

SILVA, Maria do Rosário Gomes. Ciberespaço: um espaço público virtual para a democracia contemporânea? Belo Horizonte: UniBH, 2010 .

SORJ, Bernardo. Internet, espaço público e marketing político. Novos Estudos. CEBRAP, v. 76, p. 123-136, 2006.

TARDE, Gabriel. A opinião e as massas. São Paulo: Martins Fontes, 1992. 
TREJO DELARBRE, Raúl. Internet como expressão e expansão do espaço público. Matrizes, ano 2, n.2, p. 71- 92, 2009.

YÚDICE, George. Internet en manos de sectores privados hoy está disputando el poder a los Estados. Entrevista a Karina Wroblewski. La Nación, Argentina, 17 may. 2015. Disponível em: <http://www. lanacion.com.ar/1792906-internet-hoy-esta-disputando-el-poder-a -los-estados>.Acesso em: 01 mar. 2016.

\section{Indicações para Leitura}

CABRERA, Daniel H. Lo tecnológico y lo imaginário: las nuevas tecnologias como creenciias y esperenzas colectivas. Buenos Aires: Biblos, 2006.

MORIGI,Valdir José; GIRARDI, Ilza Maria. Tourinho; ALMEIDA, Cristóvão Domingos de. (Orgs.). Comunicação, informação e cidadania: refletindo práticas e contextos. Porto Alegre: Sulina, 2011.

NOVAES, Adauto. Mutações: a experiência do pensamento. São Paulo: Edições Sesc, 2010.

SCHLUCHTER, Wolfgang. O desencantamento do mundo: seis estudos sobre Max Weber. Rio de Janeiro: Editora da UFRJ, 2014.

SILVEIRA, Sergio Amadeu da. (Org.). Cidadania e redes digitais. São Paulo:Comitê Gestor da Internet no Brasil : Maracá - Educação e Tecnologias, 2010. 


\section{Mídia, Cidadania e Utopia no Brasil José Marques de Melo}

Criação de Thomas Morus, escritor inglês (1480-1535), a Utopia é um país imaginário, onde o governo, organizado da melhor maneira, proporciona ótimas condições de vida a um povo equilibrado e feliz.

Para Thomas More, utopia era uma sociedade organizada de forma racional, as casas e bens seriam de todas as pessoas, que passariam seu tempo livre envolvidos com leitura e arte, não seriam enviados para a guerra, a não ser em caso extremo, assim esta sociedade viveria em paz e em plena harmonia de interesses.

Cidadania e Utopia são conceitos que brotaram de uma mesma conjuntura histórica. Filhos diletos da modernidade simbolizam produtos das "liberdades urbanas" que BRAUDEL (1989, p. 297-299) identifica como responsáveis pelo "primeiro surto desenvolvimentista" europeu.

A Cidadania foi sendo conquistada em meio a "tensões sociais" e "lutas de classes", gerando situações de incertezas, quando as Cidades começaram a sofrer ameaças regulatórias por parte dos Estados "modernos". Esses movimentos pendulares da vida cotidiana certamente motivaram Thomas Morus a satirizar as contradições da sua época. Concebendo a Utopia como ilha imaginária, ele tornou a felicidade patrimônio coletivo. 
Não obstante tenha sido contemporâneo do artífice do fenômeno social que hoje conhecemos pelo neologismo Mídia (MARQUES DE MELO, 2005, p. 13-22), o criador da utopia não viveu o suficiente para conhecer a Galáxia de Gutenberg. Mas se tivesse atravessado o portal do universo tipográfico, certamente desejaria recolher-se ardentemente ao seu refúgio utópico, tamanho o impacto provocado pela imprensa nos pilares da sociedade. Refletindo a intrepidez de cidadãos forjados pelo nacionalismo, pelo individualismo e pelo espírito de crítica (McLUHAN, 1972), a geografia européia expandiu suas fronteiras além mar e a história intelectual percorreu caminhos infinitos.

Os detentores do poder, nos emergentes Estados nacionais, trataram de refrear o ímpeto da Cidadania, da mesma forma que os guardiões da doutrina, no precursor Estado multinacional (Igreja Católica), não hesitaram em frear o poder revolucionário da Imprensa. E as nefastas conseqüências da engrenagem inquisitorial perduraram durante séculos. Foram neutralizadas apenas quando a Cidadania se tornou hegemônica nos Estados regidos pela democracia representativa, fortalecida pelo ideário republicano.

"O século que viu Colombo, viu Gutenberg também", proclamou retoricamente Castro Alves (1870) no poema "O livro e a América". Mas a coincidência foi mero acidente histórico, advertiu imediatamente o poeta: isso ocorreu "Por uma fatalidade. Dessas que descem de além".

Tanto assim que o itinerário da mídia impressa no continente desbravado por Colombo obedeceu uma seqüência plenamente articulada com o percurso aqui desenvolvido pela urbanização e pelo fortalecimento da cidadania (MARQUES DE MELO, 2003, 59-85). Os prelos madrugam nos territórios conquistados pelo Império Castelhano (1533), onde os colonizadores reproduzem as condições de vida desfrutadas pelos cidadãos que habitavam 
os burgos da metrópole ibérica. Eles florescem mais tarde (1638) no espaço ocupado pela Coroa Britânica, justamente quando se intensifica a migração de comunidades religiosas. Elas constroem a malha urbana das colônias agro-industriais, onde as práticas cidadãs aceleram o processo de autonomia nacional. Fenômeno contrastante ocorre na vastidão territorial da Colônia Lusitana, onde a mídia impressa foi retardada durante três séculos (1808), como decorrência da incipiente urbanização e da conseqüente ausência de Cidadania, entre outros fatores de natureza sócio-cultural.

Não é sem razão que Paulo Freire (1966) deplora o "mutismo do homem brasileiro", resultante da nossa inexperiência democrática durante o regime colonial.

"O Brasil nasceu e cresceu sem experiência de diálogo. De cabeça baixo, com receio da Coroa. Sem imprensa. Sem relações. Sem escolas. Doente. Sem fala autêntica. (...) Entre nós (...) o que predominou foi o mutismo do homem brasileiro. Foi a sua não-participação na solução dos problemas comuns. Faltou-nos, na verdade (...), vivência comunitária" (FREIRE, 1996, p. 66-70).

Desprovido de suportes midiáticos e destituído de referentes simbólicos que habilitassem ao ingresso na Galáxia de Gutenberg, o povo brasileiro foi criando sua própria mídia (artesanal, ardilosa, criativa). Trata-se do embrião da mídia cidadã, que ganharia densidade, mas não necessariamente legitimidade, na fase posterior à independência nacional. Luiz Beltrão (1967) denominou "sistema de folkcomunicação" ao conjunto dessas manifestações populares. $\mathrm{Na}$ verdade, elas permanecem vivas até os dias atuais, coexistindo dialeticamente como o "sistema de comunicação massiva". 
"As classes populares têm, assim, meios próprios de expressão e somente através deles é que podem entender e fazer-se entender. Tais meios são, ainda em grande parte aqueles mesmos que the serviram na fase da Independência: - a literatura oral, com os cantadores, as estórias e anedotas, os romances cheios de moralidade e filosofia; o jornalismo ambulante dos caixeiros-viajantes, dos choferes de caminhão, dos frades e padres missionários ou dos vigários nas 'desobrigas', dos passadores-de-bicho de engenho a engenho enchendo as 'poules' e conversando fiado, dos canoeiros do São Francisco, do Amazonas e seus afluentes; ou a literatura escrita, com os folhetos de romances ou paródias de orações católicas, os almanaques de produtos farmacêuticos, os calendários e folhinhas, os livros de sorte, publicações periódicas e avulsas impressas em prelos manuais; ou, ainda, a linguagem simbólica e eloqüente dos autos e entretenimentos, que se praticam nas festas religiosas e civicas, no São João, no Natal, durante o tríduo de Momo ou nos aprontes de marchas dos blocos ou de sambas das escolas das favelas, nos candomblés e xangôs, na Semana Santa. E também pela 'fala' explícita das peças de artesanato, de esculturas, de quadros, de móveis e utensílios rústicos" (BELTRÃO, 2003, p. 125).

Essa simultaneidade de sistemas midiáticos, um massivo (hegemônico) e outro popular (contra-hegemônico), configura paradoxo que desafia os pesquisadores da área de comunicação.

Ele faz parte da minha agenda acadêmica desde o doutorado. A tese que defendi em 1973 tinha como objetivo principal a elucidação da defasagem temporal entre o funcionamento da mídia no continente europeu e nos territórios coloniais. As variáveis contempladas reforçavam a idéia de que a ausência de urbanismo e consequentemente de cidadania inibiram o desenvolvimento da 
mídia impressa (MARQUES DE MELO, 2003). Problematizei, no livro que reúne ensaios do pós-doutorado, o papel modernizador da mídia em sociedades que mantêm contingentes humanos à margem do desenvolvimento econômico. Anula-se completamente o estímulo à "participação" que a engrenagem midiática provoca nas audiências, tendo em vista a ausência do pleno exercício da cidadania (MARQUES DE MELO, 1976, p. 30-35).

Retornei a essa questão na conjuntura da transição brasileira para o regime democrático, ao sugerir que as novas gerações de pesquisadores da área explorassem a mídia cultivada pelas classes subalternas. Ao invés de estigmatizar como espaço de alienação política, testar a hipótese da resistência possível dos excluídos pela sociedade de consumo (MARQUES DE MELO, 1980). Sistematizei posteriormente as observações sobre a contra-hegemonia exercitada pela mídia "nanica"1, robustecendo a tese de que a imprensa comunitária brasileira, com raras exceções, pauta-se por critérios e motivações externos às comunidades a que servem. Ordenei também as minhas reflexões sobre a brecha cidadã existente em nossa sociedade, tomando como referência a pedagogia da comunicação de Paulo Freire (MARQUES DE MELO, 1981).

Contribuição relevante para decifrar o enigma da mídia cidadã no Brasil foi proporcionada pelo professor Luiz Beltrão, através do livro em que redimensiona e amplia o conceito de folkcomunicação. Identificando-o como mídia dos "marginalizados", ele inventariou as formas rudimentares através das quais as classes subalternas expressam sua inconformidade em relação à sociedade

1 Expressão corrente nos anos 60-70 do século passado, designando os meios de comunicação de pequeno porte, sobretudo os tablóides e os jornais alternativos. Vide: RABAÇA \& BARBOSA - Dicionário de Comunicação, Rio de Janeiro, Campus, 2001, p. 505 
instituída pelas "camadas superiores". Coletando evidências em várias regiões do país, compôs um panorama unificado pela "universalidade que advém do folclore, desde que a autêntica cultura popular tem raízes, tronco e ramos tão profundamente arraigados na natureza humana"(BELTRÃO, 1980, p. 40).

Nessa mesma linha de resgate dos processos de comunicação popular, RIBEIRO JÚNIOR (1982) percorreu a trilha das festas populares, conceituando-as pedagogicamente como espaços de resistência cultural, onde a função "lúdica" não exclui as contradições sociais (p. 12). O autor privilegiou em sua análise as festas operárias ("festas de solidariedade" que expressam a "consciência de classe"). Ele procurou demonstrar a hipótese construída por Ecléa Bosi (1972), segundo a qual a "cultura popular é a única que se realiza na militância ou então se atrofia"

As observações de Beltrão, Bosi e Ribeiro Júnior pertencem a uma conjuntura marcada pelos estertores do regime militar. Poucos pesquisadores se aventuravam a explorar esse tipo de objeto. Os acadêmicos solidários com as classes subalternas concentravam energias na produção de um novo tipo de mídia cidadã.

Com o fim da censura (1975) e a decretação da anistia política (1979), a resistência ao sistema autoritário se fazia de modo peculiar. A pesquisa-ação tomava o lugar da pesquisa-denúncia ${ }^{2}$. No arcabouço do projeto de transição "lenta, gradual e segura" dos generais Geisel-Golbery, o mais importante era conscientizar

2 Para melhor entender essa conjuntura, vide: MARQUES DE MELO \& GOBBI - Pensamento Comunicacional Laino-Americano: da pesquisa-denúncia ao pragmatismo pedagógico, São Bernardo do Campo, Editora Meetodista, 2004 
as classes subalternas para a ocupação dos espaços reservados à cidadania ${ }^{3}$.

Isso explica o pequeno volume de estudos sobre o fenômeno da mídia cidadã. Constituem exceções, nesse panorama, o inventário realizado por Marco Morel (1986) a propósito do jornalismo popular nas favelas cariocas e a sistematização das práticas de jornalismo comunitário feita por Ana Arruda Callado (1985), em parceria com Maria Ignez Duque Estrada. São documentos que atestam o lento desabrochar da cidadania nas zonas periféricas das grandes metrópoles.

Pertencem também a essa conjuntura os esforços de reflexão coletiva sobre a construção de alternativas à mídia hegemônica, catalisando as aspirações da cidadania e fomentando a intervenção de novos sujeitos emissores. Duas associações nacionais ocupam a vanguarda desse movimento. A Sociedade Brasileira de Estudos Interdisciplinares da Comunicação (1982) dedica a primeira edição dos seus "Cadernos INTERCOM" à revisão das experiências e à proposta de formatos adequados ao "jornalismo popular", além de privilegiar a contra-informação no temário do seu congresso anual (LINS DA SILVA, 1982). A União Cristã Brasileira de Comunicação Social - UCBC proclama os "direitos humanos" como um “desafio á comunicação” (SOARES, PUNTEL \& FLEURI, 1983) e reconstitui a memória da "resistência" durante os anos de chumbo (GOMES, BULIK \& PIVA, 1989) como alerta para o trabalho das gerações emergentes.

Concomitantemente, o Programa de Pós-Graduação em Comunicação Social da hoje Universidade Metodista de São

3 Esse capítulo da nossa história recente está documentado em MARQUES DE MELO, José, org, - Comunicação e Transição Democrática, Porto Alegre, Mercado Aberto, 1985 
Paulo incluiu o novo objeto de estudos na sua agenda acadêmica. O ponto de partida foi o lançamento da edição monográfica da revista "Comunicação \& Sociedade" (1981), focalizando as relações entre a comunicação alternativa e a cultura popular. Na seqüência, três jovens pesquisadores vinculados ao Grupo de São Bernardo ${ }^{4}$, mas que também estavam na vanguarda das instituições acima referidas, ampliaram o debate sobre a questão. Regina Festa e Carlos Eduardo Lins da Silva (1986) selecionam projetos emblemáticos de comunicação popular e alternativa desenvolvidos no Brasil no período 1968-1982. Por sua vez, Luis Fernando Santoro (1989) inventaria criticamente o movimento brasileiro de vídeo popular, realçando sua colaboração para que "as classes populares possam expressar a sua própria visão de mundo, informar-se, registrar a sua história” (-p. 113).

Cresce na fase posterior à Constituinte de 1988 o interesse acadêmico pelo protagonismo da cidadania, ocupando espaços possíveis no complexo midiático. Popularmente conhecida como Constituição "Cidadã”, a nossa carta magna ampliou consideravelmente os direitos humanos, instituindo diretrizes para garantir o acesso dos cidadãos aos sistemas midiáticos, não apenas como receptores, mas como emissores ${ }^{5}$.

As brechas legalmente instituídas pelo sistema beneficiam justamente o operariado, segmento mais bem organizado e com

4 O Grupo de São Bernardo é constituído pelos mestres e discípulos do Programa de Pós-Graduação em Comunicação Social da Universidade Metodista de São Paulo.Vide:MARQUES DE MELO,José - História do Pensamento Comunicacional, São Paulo, Paulus, 2003, p. 272-287

5 Os bastidores desse episódio estão registrados por um dos seus lúcidos observadores-participantes. Vide: FREITAS NOBRE - Imprensa e Liberdade - os princípios constitucionais e a nova legislação, São Paulo, Summus, 1987 
maior tradição de luta. Através dos sindicatos, e não raro usando subsídios estatais, os trabalhadores urbanos substituem os tradicionais e rudimentares meios de comunicação pelas novas tecnologias de difusão simbólica. Adotando a estratégia rotulada como "política de resultados", muitos deles conquistam espaços no aparato legislativo e passam a influir nas decisões nacionais, alcançando até mesmo postos executivos nos governos municipais e estaduais.

Essa transição política mereceu a atenção de um contingente expressivo de pesquisadores da comunicação, alguns mais preocupados com as variáveis históricas do processo, desentranhando as raízes da mídia operária, como Ferreira (1988), Araújo \& Cardoso (1992) e Rubim (1995); outros mais interessados em conhecer o desempenho da moderna mídia sindical, como Momesso (1995), Ferreira \& equipe (1995) e Santiago \& Gianotti (1997).

Geralmente desencadeadas nos pátios ou portões das fabricas, as lutas sindicais repercutiam nas comunidades habitadas pelos operários. Sua correia de transmissão era quase sempre a imprensa mantida pelas comunidades eclesiais de base ou instituições congêneres das periferias metropolitanas. Esse filão surpreendente da mídia cidadã foi desvendado por Gomes (1990). Valendo-se da metodologia da observação-participante ele penetra no âmago dos processos comunicacionais, numa paróquia do bairro de São Miguel Paulista. E desentranha as relações conflituosas entre lideranças sindicais, partidárias e religiosas nos bastidores da produção de um jornal comunitário.

Percebe-se claramente, nesta revisão bibliográfica, que a pesquisa do exercício midiático da cidadania reduziu-se historicamente à mídia segmentada, classista ou periférica.

Por isso mesmo, ganha significação o livro de Jorge Maranhão (1993), focalizando o "papel da mídia no despertar da cidadania”. Refletindo sobre o ofício de publicitário, ele examina criticamente 
a ação de empresas, órgãos públicos e entidades da sociedade civil, iluminando iniciativas que favorecem a qualidade de vida dos cidadãos e refugando aquelas que prejudicam os interesses coletivos. Seu ponto de partida é a compreensão do estágio em que se encontra a cidadania brasileira, seus canais de expressão das reivindicações comunitárias e o tratamento que essas demandas merecem da mídia hegemônica. Trata-se, em essência, de um valioso exercício de crítica midiática, cujo ângulo de observação privilegia o cidadão-consumidor.

Contudo, o autor demonstra o seu ceticismo quanto ao papel das "elites" no fortalecimento da cidadania.

"Vira e mexe, as elites sociais brasileiras, mesmo que bem intencionadas, têm tentado promover a integração social do povo brasileiro, sem que no entanto se dêem conta de que elas próprias não estão integradas eticamente ao caráter nacional brasileiro. Se o que caracteriza as elites de outros povos é exatamente o orgulho de pertencer ao seu próprio povo, o que produz a condição de possibilidade de integração social, que é a solidariedade social, o que caracteriza as elites sociais brasileiras é a subestimação cultural $e$ a discriminação social do seu próprio povo. Pois caráter das elites nacionais é tradicionalmente vendido às referências culturais de ouros povos, um caráter simio e de pastiche, xenofilico e preconceituoso". (MARANHÃO, 1993, p. 342)

Esse desprezo pelas camadas sociais que constituem a base da nossa pirâmide social explica a natureza episódica, residual e intermitente dos espaços dedicados ao povo em movimento, vale 
dizer, à construção da nossa cidadania, na grande mídia ${ }^{6}$. Eles vão se ampliando na medida em que os cidadãos organizados em associações de moradores, clubes de mães, sociedades beneficentes e mutirões cívicos arregimentam suas próprias forças. Engendrando artificios comunicacionais - da folkmídia à webmídia - podem ultrapassar as fronteiras da periferia da sociedade, acuando, em certo sentido, as indústrias midiáticas. Elas abrem "janelas" para que as demandas cidadãs repercutam na sociedade, sensibilizando, desta forma, os detentores do poder. Mas até que as "portas" lhe sejam franqueadas, as lideranças da sociedade civil vislumbram caminho árduo a percorrer.

Trata-se de jornada complexa e sinuosa, desafiada pela multiplicação das experiências de comunicação popular que os movimentos sociais promovem em todos os quadrantes da geografia nacional.

Cicília Peruzzo (1998) iniciou o resgate crítico dessa "participação" dos agentes midiáticos na "construção da cidadania". Sua conclusão reforça a esperança de que a utopia da mídia cidadã deixe de ser "quimera" (ilusão, fantasia), concretizando-se através de processos capazes de evidenciar que "o homem e a mulher encerram a potencialidade de ser sujeitos da história" (p. 23). Assumindo a parte que lhes compete nessa caminhada, Peruzzo \& Almeida (2003) e Peruzzo (2004) vêm mobilizando a comunidade acadêmica no sentido de observar e refletir sobre as experiências de "comunicação para a cidadania". E também para reconhecer

6 Em seu artigo "Omissão das classes subalternas e da América Latina nas notícias diárias de quatro jornais paulistas", Maria Otilia BOCCINI demonstra claramente essa tendência.Vide: MARQUES DE MELO, org. - Ideologia, Cultura e Comunicação no Brasil, São Bernardo do Campo, Instituto Metodista de Ensino Ssuperior, 1982, p. 21-48 
quais "vozes cidadãs" se tornam emblemáticas, motivanmdo os novos sujeitos desse processo.

Trata-se de uma conclamação que vem produzindo resultados positivos. As principais evidências coletadas pelos jovens pesquisadores começam a demonstrar que a mídia cidadã vem sendo robustecida em todo o país.

COGO (1998) atesta a pujança das rádios comunitárias, descrevendo o caso da Rádio Popular Lagoa, de Belo Horizonte. BAZI (2001) apresenta um mapa da televisão regional paulista, focalizando “as ações conjuntas com a comunidade". FERNANDES (2003) explica como se estrutura a pequena imprensa catarinense, destacando "a força do jornal do interior". Por sua vez, DORNELLES (2004) investiga os mecanismos através dos quais os jornais que circulam em "cidades do interior" gaúcho estabelecem sintonia com as demandas "comunitárias". Trata-se de mesmo universo que havia sido palmilhado por MARQUES DE MELO \& QUEIROZ (1998) no caso da imprensa paulista, onde procuraram entender as conexões entre local, regional, nacional e global.

A utopia brasileira da mídia cidadã começa, portanto, a adquirir concretude, ultrapassando o universo da tipografia e das telecomunicações para ingressar no ciberespaço. LIMA, PRIETO \& FERREIRA (2004) sinalizam as potencialidades da mídia digital para a educação cidadã, enquanto BARBOSA FILHO \& CASTRO (2004) discutem as perspectivas de acesso das comunidades periféricas à cibercultura, reafirmando "a inclusão digital como forma de inclusão social".

Tendência idêntica de atualização histórica opera-se no âmbito da folkcomunicação. Nota-se, por um lado, a transmutação dos fluxos mediadores desencadeados pelos agentes folk, dentro das comunidades em que atuam, sob o impacto contínuo da mídia massiva, como bem o interpreta BENJAMIN (2000 e 2004). Por 
outro lado, verifica-se uma espécie de contra-fluxo folkmidiático, caracterizado pela apropriação que as indústrias culturais fazem das manifestações folclóricas. Fenômenos dessa natureza foram documentados e analisados por MARQUES DE MELO \& KUNSCH (1998) em relação aos festejos natalinos; por MARQUES DE MELO, LUYTEN \& CASTELO BRANCO no que diz respeito ao carnaval (2000), por TRIGUEIRO (2001) no caso das celebrações juninas e por HOHLFEDT (2004) no tocante à propaganda política em tempo de eleições.

Entretanto, o caminho a percorrer demanda esforço, perseverança e determinação. Trata-se de batalha cuja vitória depende fundamentalmente da vontade política dos sujeitos que estão na vanguarda da sociedade política. Mas a sociedade civil e a comunidade acadêmica podem exercer influência, acelerando o processo através de estudos e reflexões capazes de sensibilizar e convencer os que tomam decisões nas estruturas de poder.

O Brasil, a Índia e a África do Sul situam-se, hoje, na vanguarda dos países em desenvolvimento que estão desempenhando papel-chave na contestação ao regime vigente dos direitos de propriedade intelectual, fomentando iniciativas destinadas a flexibilizar o comércio mundial dos produtos audiovisuais. O Governo brasileiro, através do Ministério da Cultura e de outras agências federais, vem debatendo alternativas possíveis para fazer da inclusão digital uma alavanca para a inclusão social. Trata-se de garantir o direito de acesso universal às novas tecnologias de difusão, fomentando a expressão simbólica dos vastos contingentes que constroem cotidianamente a nossa diversidade cultural.

Foi a partir dessa contingência histórica que a World Association for Christian Commmunication - WACC e a Cátedra UNESCO/METODISTA de Comunicação se consorciaram para promover o Seminário "Mídia Cidadã", realizado nos dias 28-30 
de novembro de 2006, no campus Rudge Ramos da Universidade Metodista de São Bernardo do Campo. O evento reuniu meia centena de participantes, oriundos de dois segmentos distintos da atividade intelectual: jovens pesquisadores vinculados a instituições acadêmicas do campo comunicacional e ativistas midiáticos engajados nos movimentos sociais.

A agenda dos debates foi construída em função do conhecimento disponível sobre o objeto. Tratando-se de fenômeno complexo e multifacetado, optou-se por eleger aquelas dimensões melhor registradas na literatura acadêmica. As tendências previamente observadas, cujo esboço está contido na parte inicial deste ensaio, evidenciavam que três variáveis possuíam referencial cognitivo suficiente para justificar sua inclusão na pauta dos trabalhos: imprensa local, rádios comunitárias e folkcomunicação. A elas deveríamos agregar uma quarta variável. A escolha recaiu sobre a mídia digital, tendo em vista que os diagnósticos sobre a questão eram mais consistentes e atualizados que a respeito de outras variáveis.

Os "territórios midiáticos" a suscitar a observação dos participantes do seminário foram assim definidos:

Imprensa local - mídia impressa de pequeno porte, publicada nos espaços municipais ou nas periferias metropolitanas, perfilando pequenos negócios, catalizando interesses corporativos, subsidiando iniciativas governamentais ou mobilizando as forças vivas das comunidades atuantes nas diferentes regiões brasileiras.

Rádios comunitárias - estações de baixa frequiência que funcionam como serviço público, competindo com as redes comerciais, no sentido de acolher, endossar e/ou estimular os movimentos sociais. 
Folkcomunicação - canais preservados pelos grupos socialmente marginalizados para expressar sua resistência à cultura das classes dominantes, realizando operações de decodificação das mensagens difundidas pelas redes de comunicação massiva.

Mídia digital - canais de comunicação que otimizam novas tecnologias digitais, especialmente a internet, para agendar publicamente as manifestações simbólicas e as reivindicações comunitárias das organizações periféricas, das minorias excluídas e dos grupos culturalmente marginalizados.

Tal revisão contemplou de modo vertical todo o sistema brasileiro de comunicação, recortando-o a partir de três níveis analíticos: macro - o contexto midiático -, meso - as políticas públicas - e micro - as relações de gênero. Denominados "eixos focais", eles foram assim definidos:

Contexto midiático: o sistema nacional no espaço global. Visão panorâmica das redes industriais - imprensa, rádio, televisão, cinema e vídeo, internet e tecnologias emergentes -, bem como dos serviços comerciais - publicidade, relações públicas, agências noticiosas, bancos de dados, entretenimento, teleducação - focalizando suas relações de poder (privado, estatal, multinacional) e suas estratégias de interação cidadã.

Políticas públicas: os direitos à comunicação e o regime de propriedade intelectual. Análise das políticas públicas brasileiras nos campos da comunicação e da informação, 
identificando os obstáculos e incentivos ao exercício universal do direito à informação, à comunicação e à liberdade de opinião, inclusive o estatuto da propriedade intelectual numa conjuntura globalizante, marcada pelo temor de homogeneização cultural, com prejuízos incalculáveis para a diversidade cultural do planeta.

Questão de gênero: inclusão/exclusão da mulher no complexo midiático Resgate da militância feminina pela ocupação de espaços no interior do complexo midiático, desde os conglomerados industriais às agências comunitárias e aos serviços populares; agenda das conquistas consolidadas e das batalhas persistentes.

Especialistas em cada uma dessas dimensões territoriais e níveis interpretativos foram convidados a oferecer suas contribuições para o debate, cruzando pontos de vista numa espécie de "agora" pós-moderna, complementada por um "fórum" aberto, porque receptivo à participação de todos os interessados, através da internet.

Durante três dias, todos os sujeitos engajados nesse mutirão intelectual confrontaram civilizadamente suas teses e argumentos, tanto em sessões plenárias quanto em grupos temáticos. Ao final, esboçaram o "mapa brasileiro" da mídia cidadã neste limiar do século XXI.

A "Carta de São Bernardo" sintetiza os principais elementos dessa cartografia intelectual.

Ela estabelece premissas fundamentais:

1) O princípio da comunicação como direito humano fundamental pressupõe não somente o acesso, mas a construção de conteúdos, a apropriação da tecnologia e a multiplicação da diversidade 
cultural e da socialização do conhecimento, contemplando politicas públicas de proteção dos conteúdos locais/regionais/nacionais e das indústrias criativas.

2) O conceito de interesse público transcende o de estatal, justificando a ampliação dos recursos públicos para a sustentabilidade da mídia local, assim como a instituição de fundos públicos para a mídia comunitária.

3) A construção coletiva e participativa do conhecimento constitui a meta dos movimentos de acesso livre e em defesa do software livre, demandando um novo estatuto da propriedade intelectual, no sentido de viabilizar padrões tecnológicos abertos para o intercâmbio de informação e utilização integrada de distintas plataformas tecnológicas.

E aprovou recomendações estratégicas:

1) O Estado deve assumir sua responsabilidade no sentido de estabelecer Políticas Públicas e critérios claros na descentralização das verbas publicitárias em âmbito federal, estadual, municipal e distrital, favorecendo a regionalização da comunicação e fiscalizando nas empresas midiáticas o cumprimento das finalidades de informação, educação, entretenimento e cultura, previstas pela Constituição Federal. Trata-se de modificar a realidade, garantindo a sustentabilidade da mídia local e comunitária sintonizada com o interesse público.

2) As empresas de mídia devem ampliar sua participação social, através de ações e conteúdos dentro dos princípios da mídia cidadã; valorizar e qualificar seus profissionais nos princípios de responsabilidade social; inserir conteúdos locais/regionais, 
respeitando e garantindo a diversidade cultural; estimular a presença de minorias e difundir os direitos humanos nos conteúdos midiáticos, preservando assim as identidades e peculiaridades, locais ou regionais.

3) As instituições universitárias devem assumir a responsabilidade de promover cursos voltados para a formação de comunicadores/ empreendedores, profissionalização e modernização de empresas e instituições, criando, inclusive, incubadoras de mídia local/regional. Para isso devem implantar novas linhas de pesquisa nos cursos de pós-graduação, ancoradas na relação da Comunicação com a Educação e o Desenvolvimento Comunitário, com ações integradas à graduação.

4) A comunidade acadêmica deve incentivar a produção de conteúdos dialógicos, que incluam entretenimento e educaşão para diferentes suportes midiáticos, bem como a convergência tecnológica, valorizando as identidades, as singularidades locais e a responsabilidade social. Além disso, deve promover parcerias entre as instituições de ensino e de comunicação com a sociedade civil para um levantamento da memória e da cultura das comunidades periféricas por meio de projetos de mídia cidadã, histórias de vida e relatos orais.

Mas também formulou questões específicas:

1) A mídia local/regional ocupa papel-chave no desenvolvimento da cidadania, possuindo interfaces com as questões sociais, econômicas, políticas e culturais. Apesar do crescimento e diversidade da mídia local, persiste a reprodução dos padrões da grande mídia nacional/global, com pouco espaço para novos formatos, linguagens e mesmo conteúdos apropriados 
2) A sociedade demanda às emissoras comerciais e educativas a abertura de novos espaços, gratuitos, para a veiculação de programas produzidos por organizações comunitárias, considerando o caráter concessionário dessas emissoras. Concita igualmente o governo federal para agilizar o trâmite dos processos de liberação das concessões de novas emissoras comunitárias e para permitir o aumento da potência e do número de canais, a veiculação de publicidade, a atuação em cadeia. Reivindica também a descriminalização das emissoras comunitárias que operam sem autorização, garantindo a veiculação de programas produzidos por organizações comunitárias.

3) As intersecções entre a folkcomunicação e a mídia massiva pode fortalecer a diversidade cultural, através dos espaços compartilhados e dos conteúdos comuns, Esse tipo de ação não deve se limitar à apropriação das tecnologias, mas se estender ao marco regulatório dos conteúdos e dos processos comunicacionais. Nesse sentido, torna-se premente avaliar - por meio de leitura crítica - as produções midiáticas para que contemplem as temáticas e abordagens voltadas para uma prática cidadã no contexto da folkcomunicação. Trata-se de catalisar a resistência cultural das classes subalternas e dos grupos social e politicamente marginalizados, transformando-a em alavanca para a inclusão midiática.

4) A sociedade civil pode desempenhar função estratégica no processo de regulamentação da emergente mídia digital (rádio e $T V)$, lutando pela adoção de padrões e modelos técnicos os mais abertos possíveis, que contemplem os objetivos e princípios de interatividade, usabilidade, interoperabilidade, escalabilidade, universalização e sistema compartilhado. 
O texto completo da "Carta de São Bernardo" está reproduzido no final do volume, "Mapa da Mídia Cidadã: Brasil, século XXI" editado pela Cátedra UNESCO/METODISTA de Comunicação, 2006.

\section{Referências bibliográficas}

ARAÚJO, Silvia \& CARDOSO, Alcina 1992 - Jornalismo \& militância operária, Curiiba, Editora UFPR

BARBOSA FILHO, André \& CASTRO, Cosette 2005 - A inclusão digital como forma de inclusão social, In: BARBOSA

FILHO, André, CASTRO, Cosette \& TOME, Takashi - Mídias digitais, São Paulo, Paulinas, p. 273-294

BAZI, Rogério 2001 - TV Regional, Campinas, Alínea

BELTRÃO, Luiz 1980 - Folkcomunicação, a comunicação dos marginalizados, São Paulo, Cortez 2003 - Folkcomunicação, Porto Alegre, Edipucrs

BENJAMIN, Roberto 2000 - Folkcomunicação no contexto de massa, João Pessoa, Ed. UFPB 2004 - Folkcomunicaşão na sociedade contemporânea, Porto Alegre, Comissão Gaúcha de Folclore

BOSI, Ecléa 1972 - Cultura de Massa e Cultura Popular, Petrópolis, Vozes

BRAUDEL, Fernand. 1989 - Gramática das Civilizações, São Paulo, Martins Fontes 
CASTRO ALVES 1870 - Espumas Flutuantes, Salvador

CALLADO, Ana Arruda \& ESTRADA, Maria Ignez Duque 1985 Como se faz um jornal comunitário, Petrópolis, Vozes

COGO, Denise 1998 - No ar... uma rádio comunitária, São Paulo, Paulinas

DORNELLES, Beatriz 2004 - Jornalismo "comunitário" em cidades do interior, Porto Alegre, Sagra-Lusatto

FERNANDES, Mario Luiz 2003 - A força do jornal do inerior, Itajaí, UNIVALI

FERREIRA, Maria Nazareth 1988 - Imprensa operária no Brasil, São Paulo, Ática

FERREIRA, Maria Nazareth e equipe 1995 - O impasse da comunicação sindical, São Paulo, Cebela

FESTA, Regina \& LINS DA SILVA, Carlos Eduardo 1986 Comunicação popular e alternativa no Brasil, São Paulo, Paulinas

FREIRE, Paulo 1966 - Educação como prática da liberdade, Rio de Janeiro, Paz e Terra

GOMES, Pedro Gilberto 1990 - O jornalismo alternativo no projeto popular, São Paulo, Paulinas

GOMES, Pedro Gilberto, BULIK, Linda \& PIVA, Márcia 1989 Comunicação, Memória \& Resistência, São Paulo, Paulinas 
HOHLFELDT, Antonio 2004 - A imagem da política e dos políticos na perspectiva da Folkcomunicação, Anuário Unesco/Umesp de Comunicação Regional, 8 (59-78), São Bernardo do Campo, Editora Metodista

INTERCOM 1982 - Jornalismo Popular, Cadernos Intercom

LIMA, M. Fátima; PRIETO, Nelson \& FERREIRA, Lucrecia 2005 - Mídia digital e educação: tudo ao mesmo tempo agora o tempo o tempo todo, In: BARBOSA FILHO, André, CASTRO, Cosette \&

TOME, Takashi - Mídias digitais, São Paulo, Paulinas, p. 225-256

LINS DA SILVA, Carlos Eduardo 1982 - Comunicação, hegemonia e contra-informação, São Paulo, Cortez/Intercom

MANNION, James 2004 - O livro completo da filosofia, São Paulo, Madras

MARQUES DE MELO, José 1976 - Subdesenvolvimento, urbanização e comunicação, Petrópolis, Vozes 1980 - Comunicação e Classes Subalternas, São Paulo, Cortez 1981 - Comunicação \& Libertação, Petrópolis, Vozes 2003 - História Social da Imprensa, Porto Alegre, Edipucrs

MARQUES DE MELO, José \& QUEIROZ, Adolpho 1998 Identidade da imprensa brasileira no final do século, São Bernardo do Campo, Editora Metodista 
MARQUES DE MELO, José \& KUNSCH, Waldemar 1998 - De Belém a Bagé, imagens midiáticas do Natal Brasileiro, São Bernardo do Campo, Editora Metodista

MARQUES DE MELO, José; LUYTEN, Joseph \& CASTELO BRANCO, Samantha 2000 - Imagens Midiáticas do Carnaval Brasileiro, Anuário Unesco/Umesp

de Comunicação Regional, 4 (113-202), São Bernardo do Campo, Editora Metodista

MARANHÃO, Jorge 1993 - Mídia e cidadania, Rio de Janeiro, Topbooks

McLUHAN, Marshall 1972 - A Galáxia de Gutenberg, São Paulo, Nacional

MENDONÇA, Nadir Domingues 1983 - O uso dos conceitos, Petrópolis, Vozes

MOMESSO, Luiz 1997 - Comunicação sindical: limites, contradições, perspectivas, Recife, Editoras UFPE

MOREL, Marco 1986 - Jornalismo popular nas favelas cariocas, Rio, RioArte

PERUZZO, Cicília 1998 - Comunicação nos movimentos populares: a participação na construção da cidadania, Petrópolis, Vozes

2004 - Vozes Cidadãs, São Paulo, Angellara 2015 - Comunicação popular, comunitária e alternativa no Brasil, São Paulo, Editora UMESP 
PERUZZO, Cicília \& ALMEIDA, Fernando 2003 - Comunicação para a Cidadania, Salvador, UNEB / São Paulo, INTERCOM

RIBEIRO JÚNIOR, Jorge Cláudio Noel 1982 - A festa do povo, Petrópolis, Vozes

RUBIM, Albino 1995 - Marxismo, cultura e intelectuais no Brasil, Salvador, UFBA

SANTIAGO, Claudia \& GIANOTTI,Vito 1997 - Comunicação sindical: falando para milhões, Petrópolis, Vozes

SANTORO, Luiz Fernando 1989 - A imagem nas mãos - o vídeo popular no Brasil, São Paulo, Summus

SOARES, Ismar; PUNTEL, Joana \& FLEURI, Reinaldo 1983 Direitos humanos: um desafio à comunicação, São Paulo, Paulinas

TRIGUEIRO, Osvaldo 2001 - O São João de Campina Grande na Mídia, Anuário Unesco/Umesp de Comunicação Regional, 5 (135-150), São Bernardo do Campo, Editora Metodista 


\section{INTELECTUAIS E WEB 2.0/3.0: COMO PENSAR, NO $3^{\circ}$ MILÊNIO, A UTOPIA DO INTELECTUAL ${ }^{1}$}

Pedro de Andrade ${ }^{2}$

\section{Introdução}

$\mathrm{Na}$ actual conjuntura de globalização da informação, os media apresentam uma natureza não apenas convergente, mas também indefinidamente fluida, infinitamente híbrida, e surpreendentemente camaleónica. Arjun Appadurai fala de 'paisagens dos media' ou mediascapes, para significar o papel que os media electrónicos ocupam na produção e difusão de fluxos de cultura e de imagens globais. Neste contexto planetário da informação e do conhecimento, os intelectuais definem-se, antes de mais, enquanto 'intelectuais mediáticos', na medida em que, quase obsessivamente, como se verá, procuram intervir nos media ou são por eles, cada vez mais, convocados. Entretanto, ao fazê-lo, confrontam-se com modos de acção e de reflexão inéditos e algo perturbadores.

1 Texto produzido especialmente para a Coleção Convite. Por decisão dos editores, e em homenagem aos utopistas portugueses, o texto se mantém conforme os parâmetros linguísticos do Português de Portugal.

2 Doutor em Sociologia da Cultura e Comunicação e Professor do Centro de Estudos de Comunicação e Sociedade, Instituto de Ciências Sociais, Universidade do Minho, Portugal 
Afim de captar esta realidade complexa, por um lado apontarei algumas notas, ou posts um pouco à maneira da blogosfera, mas desta vez usando aquilo que se poderá nomear posts teóricos. Para além disso, apresentarei um estudo de caso empírico sobre uma das múltiplas arenas de actuação possível do intelectual, o ciberespaço e, em especial, a cena da Web 2.0 (ou Web Social) ou da Web 3.0 (ou Web Social-Semântica).

Como se sabe, a Web 2.0 funda-se em 3 parâmetros centrais:

(a) o software utilizado pelo infonauta pode ser acedido colectivamente (social software);

(b) o usuário da Web 2.0 é um utilizador-produtor, ou seja, não apenas leitor mas igualmente um escritor que participa activamente na construção, reconstrução e desconstrução dos conteúdos;

(c) e fá-lo tendo em vista a emissão e recepção de uma informação partilhada, nomeadamente no seio de redes sociais digitais.

Daí que a Web 2.0 tenha sido denominada, amiúde, como uma reading-writing internet.

No entanto, hoje encontramo-nos imersos numa inédita incarnação da internet, a Web 3.0. Nos seus sites e redes, a informação transforma-se em conhecimento partilhado, de maneira muito mais profunda daquilo que acontece na Web 2.0.Veremos como isto se processa no estudo de caso apresentado abaixo.

\section{Dez posts sobre o intelectual no seio das redes sociais pré-digitais e digitais}

Comecemos por aspectos mais abrangentes da reflexão sobre o intelectual, como as questões sobre os espaços e os tempos sociais e públicos nos quais o intelectual intervém, para podermos entender 
melhor o campo dos media e o poder subjacente, a cultura mediática ou os novos desafios introduzidos pelos media digitais.

\section{Post 1. Espaço social e público da intelligentsia}

A visibilidade sócio-cultural do intelectual obedece a condições específicas de desenvolvimento da sociedade, da cultura e dos próprios media. Gerard Leclerc (2003) questiona a pertença deste actor a certas classes ou grupos sociais, a sua realidade estatística ou as redes de afinidades em seu torno.

Para além de uma tal sociologia da intelectual ainda a desenvolver, é urgente circunscrever a economia da intelligentsia. A sua inserção sócio-económica revela uma situação muitas vezes dificil, representada na figura social do intelectual precário 'intello précaire', conceito forjado por Anne e Marine Rambach (2001). O trabalhador intelectual insere-se por vezes numa lógica liberal, onde a precaridade se mostra orgânica, mesmo para profissionais competentes e polivalentes. $\mathrm{O}$ intelectual pertence a um segmento de consumidor muito específico. Este nicho é hiperactivo na aquisição de bens e serviços culturais, e desvaloriza o consumo tradicional de bens domésticos (habitação, alimentação, etc.).

Por seu lado, Thomas Bender (1997) alega que a organização da vida intelectual é um produto da História, e não apenas decorrente da lógica do desenvolvimento social ou do conhecimento em si. Em particular, as relações entre a Academia e a cultura urbana encontram-se em plena mudança. Ou seja, os intelectuais universitários incorporam grandes tensões quando confrontam a sua vida profissional com a experiência da cidadania. Segundo o autor, os intelectuais americanos sofreram, desde o século XIX, um processo de intensa especialização profissional e autonomização, no 
quadro da sua acção em termos de discussão pública de questões de interesse geral. Após a demissão da noção republicana da esfera pública, emerge uma versão mais pluralista do espaço público, em articulação com a revisitação de teorias pragmáticas da verdade. Esta tendência, de acordo com Bender, conduz a uma mais profunda colaboração entre a democracia e os intelectuais.

Outra via de interpretação possível é uma espécie de antropologia da intelligentsia. $O$ intelectual tradicional refugiou-se frequentemente na incompatibilidade entre viver e pensar, de acordo com François Negroni (2006). Com efeito, Durkheim e Bergson recolhiam-se na intimidade e sacríficio do seu trabalho intelectual. Todavia, principalmente a partir dos anos 30 do século XX, a cena modifica-se. Os existencialistas dão o tom, cultivando a exposição pública das ideias no café e noutros locais públicos informais ou festivos. Os jovens intelectuais dos anos 60 articularam a discussão com o amor livre. Nos anos 80 e 90, o intelectual reconhece-se sobretudo através da figura de estrela mediática, exibindo um 'look cultural' ao prununciar-se sobre assuntos que vão desde o Afeganistão até à opinião sobre uma receita culinária. Assim fazendo, este agente poderá mesmo eclipsar os escritores e artistas, os seus antigos rivais enquanto paradigma cultural e existencial, segundo Negroni.

Em Portugal, um tal fenómeno de mix mediático é visível, por exemplo, na necessidade, que muitas figuras da cultura exibiram nestes últimos anos, em opinar sobre o futebol ou acerca de outros assuntos de interesse geral menos legitimados como 'sérios', e que proporcionam uma 'votação' pública não nas ideias expressas, mas em quem as exprime. De alguma forma, oscilamos hoje entre uma democracia política e uma democracia mediática.

\section{Post 2. Tempo social e público dos media, sociedade da investigação e cibertempo}


Se passarmos agora para a dimensão das temporalidades públicas dos media, repare-se, antes de mais, que o século XX foi apelidado o 'século dos intelectuais'. Michel Winock (2006) sustenta que essa genealogia da intelligentsia funda-se mais numa sucessão de afrontamentos, ódios e amizades, do que numa história de pessoas, de ideias e de obras.

Presentemente, as actuações dos profissionais dos media e de outros agentes e gatekeepers envolvidos nas redes dos media, nas quais o intelectual se insere, registam cumplicidades, mas igualmente confrontações inéditas. Por exemplo, cada vez mais o jornalista (e não apenas o jornalista de investigação) assume-se como um sociólogo a curto prazo. Da mesma forma, o sociólogo afirma-se, paulatinamente, enquanto jornalista a médio prazo. De facto, encontramo-nos hoje imersos não apenas numa sociedade da informação, mas igualmente numa sociedade da investigação e do jornalismo (Andrade, 2008).

Nesta sociedade da investigação e do jornalismo, todos temos acesso (pelo menos em princípio) a meios de recolha da informação de natureza jonalística em $1^{a}$ mão, por exemplo por meio de telemóveis, como se passou no atentado na estação ferroviária de Atocha, em Madrid e no ano de 2004. Mas, para além disso, todos podemos fazer pesquisa (também numa primeira aproximação), inclusive investigação científica, por exemplo através de alguns dos instrumentos da Web 2.0, como o Google.

Por outro lado, no seio da problemática do tempo dos media, não podemos reduzir o ciberespaço a ele mesmo, mas é necessário confrontá-lo, incessantemente, ao cibertempo, organicamente inerente ao ciberespaço. O cibertempo consiste no conjunto de temporalidades, de natureza múltipla, activadas pelo infonauta durante a navegação no ciberespaço. Como ilustração da versatilidade e virtualidades do cibertempo, confronte-se o tempo diferido da web page de um professor, com o compasso diário do blogue 
de um investigador ou com o ritmo imediatista, em tempo real, de um chat ou de uma ligação dem Skype, entre dois ou mais jornalistas (Andrade, 1996, 1997, 2008).

\section{Post 3. Campo dos media e poder intelectual}

O espaço e o tempo públicos de co-presença entre atores sociais, atrás referidos, ou as suas versões digitais (o ciberespaço e o cibertempo), influem no campo dos media. O campo social é um conceito desenvolvido por Pierre Bourdieu, que o entende como um espaço reticular (em rede) de poder, onde os agentes sociais utilizam diversos tipos de capital (económico, social, cultural, intelectual, simbólico, etc.), em vista à manutenção ou obtenção desse mesmo poder, ao longo do tempo das suas vidas. Ora, o campo social dos media alargou-se extraordinariamente nas últimas décadas. Daí que as prioridades tradicionais dos Media Studies também se tenham metamorfoseado inexoravelmente.

Por exemplo, as relações de poder tecidas pelos agentes que subjazem ao campo dos media, em particular o poder intelectual mantido ou disputado pelos intelectuais mediáticos, apresentam hoje traços inéditos. Nesta perspectiva, a variante Francesa do poder intelectual foi analisada extensivamente por Régis Débray (1986).

Nas sociedades contemporâneas, o poder intelectual funda-se em redes nunca dantes vistas. Emmanuel Lemieux (2003) refere a necessidade de evolução do intelectual em vista à sua própria sobrevivência. Ou seja, este agente cultural deve intervir nos media, investindo mais na postura do que nas ideias, preferindo a palavra ao pensamenrto, e preocupando-se mais intensamente com a opinião pública do que com a ideologia. $\mathrm{O}$ autor estabelece uma tipologia dos novos intelectuais que polulam nas redes de influência mediáticas: os 'mediacratas', os 'especialistas', os 'oráculos', os 
'universitários', os 'seminaristas', os 'comunistas órfãos', os 'bourdieusiens', os 'intelectuais ministeriais', os 'novos predicadores islamistas', os 'néo-reacionários', etc.

\section{Post 4. Cultura mediática: a representação dos intelectuais e sua utilização dos media.}

Edward Said (1996) escreveu uma obra de referência sobre as representações do intelectual. Para ele, isso significa duas coisas: a representação de uma ideia para um público, bem como a representação da imagem do próprio intelectual. $\mathrm{O}$ autor defende o acto de falar em si próprio, ao sugerir que o intelectual deverá manter um cepticismo vigilante sobre qualquer saber consolidado. Nesta óptica, Said exprime algumas reservas em relação ao perito, que veicula um saber objectivo ou de aconselhamento para um governo, empresa, organização mediática ou política, etc. Prefere antes uma perspectiva do intelectual enquanto marginal, mesmo amador, autor de uma linguagem que pretende falar a verdade ao poder. No fundo, Said visa reconcliliar a independência do intelectual ao seu compromisso necessário.

Já reparámos que os media constituem um lugar privilegiado para a intervenção dos intelectuais na esfera pública e, em particular, na esfera política, como se sabe desde o célebre Affaire Dreyfus. Numa tal participação, de acordo com Antoine Spire e Judith Wolf (1996), mostra-se central avaliar qual a 'justa distância' que o intelectual e o artista mantém ou deverão traçar com a política. Os percursos dos intelectuais interpelados no medium específico que constitui este livro dos 2 autores, exibem diferentes mas estimulantes perspectivas acerca dessa interrogação, através dos testemunhos de Edgar Morin, Roland Castro, Jean-Pierre Vernant, entre outros. 
Em diversos assuntos para além da política, nos nossos dias, o 'intelectual de media' (Buxton et al, 2006), ocupa uma posição central, por ex. nas figuras de comentador, editorialista, ensaísta ou filósofo. Note-se que, nesta reflexão, os autores ccupam-se mais dos media 'clássicos' (não-digitais), ao referirem que os julgamentos de valor são monopolizados por uma minoria de especialistas.

Entretanto, muitos mediadores que desenvolvem a sua acção em instituições não propriamente mediáticas à partida, como as universidades ou o mundo da arte, só o serão plenamente se souberem utilizar os mass media mais legitimados, como os jornais ou a televisão. Por exemplo, Claude Jaeglé (2007) procura instruir diversos tipos de intelectuais e artistas na dificil arte de comunicar com os jornalistas, no âmbito da construção da sua imagem pública, através dos referidos mass media 'clássicos'.

Por seu lado, o intelectual público constitui uma outro modo de representação dos intelectuais nos campos dos media e da cultura, não necessariamente coincidente com o intelectual de media acima referido. John Michael (2000) defende que a democracia não se afigura viável sem a participação dos intelectuais, na sua tripla valência de crítico da sociedade e da cultura, de cientista e de profissional do saber. $\mathrm{O}$ autor alega que a intelectualidade originada no Iluminismo encerra uma complexidade onde sobressaem a ambivalência, a ansiedade, a projecção, a identificação e a hibridade. O discurso público da modernidade é assim composto não só de razão, justiça e igualdade, mas igualmente inclui o multiculturalismo, o relativismo e um saber multidisciplinar.

Este conceito de 'intelectual público'é retomado por Richard Posner (2003), que o define como um comentador crítico, que se dirige a audiências não especializadas, sobre assuntos de interesse público geral. $\mathrm{O}$ autor distrinça os indicadores sociais da notoriedade do intelectual, por ex. as menções em media impressos, os 
livros vendidos, o $\mathrm{n}^{\mathrm{o}}$ de visitas em páginas da Internet. Estabelece ainda uma tipologia dos intelectuais, como o crítico literário politicamente inclinado, entre outros. Após várias análises teóricas e estatísticas dos seus dados, Posner conclui que o intelectual público atual encontra-se em declínio, na medida em que poucos dos seus representantes conseguem uma pontuação elevada nos indicadores selecionados ou em categorias tomadas como referência, como o temperamento, a perspectiva, o carácter ou o conhecimento. Para além disso, a proliferação de novos media suscita a necessidade de mais cabeças pensantes. Mas a combinação desta urgência mediática com as insuficiências do intelectual provocou, nas últimas décadas, um discurso público inadequado. Por exemplo, na televisão por cabo, o volume da informação substitui a razão, nos debates públicos. Outro motivo desta decadência, segundo o autor, é o hábito de os intelectuais falarem em assuntos fora do seu domínio.

\section{Post 5. Papel do intelectual: crítica e/ou autismo público?}

Retomemos a genealogia sócio-cultural do intelectual, para melhor entender a questão específica do seu papel e estatuto actuais, positivos ou negativos, aclamados ou contestados. Pierre Bourdieu (1996) delineia a figura do 'intelectual total', baseandose no paradigma fundado por Jean-Paul Sartre desde os anos 50 do século passado. Trata-se de uma personagem cultural e mediática cujo 'capital intelectual' abrange competências em diversas áreas do saber, como a Filosofia, a teoria, a crítica e a autoria literárias, etc.

De alguma forma, Noam Chomsky aparece hoje enquanto herdeiro desta concepção de compromisso, e mesmo militante, do intelectual, mas aplicada à sociedade actual, e à sociedade da informação em particular. Chomsky (1998) interroga se é possível 
formular um julgamento justo na base de informações falsas. Assim, este linguista com preocupações políticas, insiste mais nos paralelos e ilações que se podem deduzir dos factos, do que nos dados em si. Por exemplo, qual o modo de representação, por parte da intelligentsia Ocidental, dos conflitos ocorridos no estangeiro? Chomsky conclui que existe hoje um obscurantismo não tanto religioso, mas científico, fundado na negação dos factos reais que se oponham às teorias estabelecidas. Numa tal conjuntura, o papel do intelectual consiste em usar a sua respeitabilidade para lutar contra aquele obscurantismo científico.

Outro papel do intelectual, para além da intervenção pública no espaço nacional ou global, é a participação naquilo que Habermas nomeia 'esfera semi-pública'. É o caso de certas instituições organizações ou associações de mediação, mas que efectuam a difusão da informação ou do saber em territórios algo circunscritos, como o campus universitário ou os espaços semi-privados dos sindicatos. Neta arena, Henry Giroux (1988) defende que os professores e o restante pessoal das instituições educativas se tornem intelectuais, a partir de um maior envolvimento, sentido de transformação e procura de empowerment de si próprios e dos seus alunos. O resultado desta postura será a proposta de pedagogias contra-hegemónicas, que preparem os estudantes para a vida profissional, enquanto agentes transformadores simultaneamente dos locais de trabalho e da sociedade em geral.

Actualmente, o intelectual exibe uma pluralidade ainda mais diversificada, em termos de figuras, posturas e trajectórias, no seio do espaço público, lugar de eleição dos seus modos de acção (Kouvouama et al, 2007). As suas produções polimórficas fundamse num saber crítico, que opina tipicamente, entre outros assuntos, sobre a democracia, o plano ético na intenção e exigência da verdade, a prática do diálogo e o reconhecimento do Outro. 
No entanto, por vezes, o intelectual interventor nos media ocupa esse território de um modo abusivo, segundo Nocolas Beau e Olivier Toscer (2006). Os 2 autores notam que essa prática é perfeitamente simbolizada por Bernard-Henry Lévy, que se instituíu, pela via mediática e pela gestão cuidada da sua própria imagem, como o 'pensador nacional' Francês por definição. Aliás, este 'novo filósofo', como que a preparar o terreno para esse pepel, escrevera, no final dos anos 80 , um livro sobre o protagonismo dos intelectuais (1988).

Outra deriva ou desvio intelectual é o terrorismo intelectual, de acordo com Jean Sévillia, (2004). É como se apenas uma minoria de pensadores detivesse a posse da verdade única, e postulasse arbitrariamente as exclusões necessárias para a manutenção do poder daquela élite. $\mathrm{O}$ autor identifica várias metodologias de marginalização e descrédito dos 'dissidentes', como a amálgama, o processo de intenção e a caça à bruxas. Esta situação de terrorismo intelectual engendra o fim do verdadeiro debate.

Ainda uma variante do abuso dos clercs consiste na figura da impostura intelectual. Neste aspecto, o livro de Alan Sokal e Jean Bricmont (1999) suscitou uma discussão acesa nos media globais. Os autores constestavam essencialmente o relativismo pós-moderno, em termos de uma aparente erudição científica que ocultava um amadorismo errático e até uma posição política conservadora. Os mais visados são alguns dos mais preminentes analistas da pós-modernidade, especialmente intelectuais Franceses oriundos de diversas disciplinas das Ciências Humanas. Resta saber se a principal motivação deste processo acusatório não se deve precisamente ao protagonismo inesperado das Ciências Sociais na arena global das Science Wars, e a correspondente ameaça à hegemonia das Ciências Exactas neste plano. 
De qualquer modo, será que o conjunto dos diversos excessos do poder do saber poderão ser nomeados, contraditoriamente, 'autismo público'? Com efeito, muitas destas derrapagens exibem posturas narcísicas, voltadas para si próprias, mas igualmente endereçadas a segmentos específicos de público e de audiências, no seio da esfera e do espaço públicos planetários.

\section{Post 6. A nova morte do intelectual (ou quantas vidas ele tem)?}

Entretanto, uma tal versatilidade do intelectual pode esconder um esgotamento das suas virtualidades. Já Sartre colocava a questão da possível 'morte do intelectual', ou pelo menos da sua versão de 'intellectuel engagé'. Também Bourdieu se questionou sobre a eficácia do intelectual, que ligeiramente ignorava os excessos do Goulag ou do socialismo na União Soviética. Tais derivações perversas do socialismo já tinham sido debatidas por Cornelius Castoriadis e por outros intelectuais na revista Socialisme ou Barbarie, no final dos anos 50 do século XX.

Muitos outros intelectuais partilham esta auto-crítica, como Michel Foucault, que aludiu ao fim dos filósofos. De seu lado, Baudrillard (1982) defende o fim do social e dos próprios políticos, na medida em que as sociedades actuais e a modernidade são fundadas em maiorias ailenciosas, constituídas pela 'massa', essa entidade neutra, implosiva, inerte, má condutora do social, do político e do próprio sentido, e cujo modo de aparição, tipicamente estatístico, é a sondagem..

Mais recentemente, Jean-François Lyotard retoma este desassossego, na sua obra Tombeau de l'Intellectuel (1984). O autor argumenta que, na pós-modernidade, era da dissolução das grandes narrativas e dos discursos 'absolutos' e 'universais', o intelectual 
perde a sua razão de ser, precisamente porque já não existem as grandes ideias e causas que comentava, em termos da sua adesão ou crítica. Mas quem virá preencher este espaço vazio? Lyotard responde que são os novos quadros que exercem profissionalmente a inteligência, não enquanto sujeitos universais, mas em vista à realização das melhores performances possíveis.

Por seu turno, Régis Debray (2000) advogou igualmente a inutilidade do intelectual, em particular do I.F. (intelectual Francês), e a sua passagem de I.O (o intelectual original Émile Zola) para o I.T. (intelectual terminal). Tal metamorfose fundamentase no facto de que este agente social, nas últimas décadas, sofreu uma acentuada perda de prestígio, devido a gritantes equívocos em diagnósticos sobre política mundial.

Recentemente, Eric Méchoulan (2005) tenta propôr uma alternativa ao crepúsculo dos intelectuais. Parte igualmente da constatação do esgotamento do paradigma do intelectual, cujos excessos mais frequentes são o delírio da interpretação ou a própria tirania da clareza. Dai decorre a tendência ao anti-intelectualismo, que encontra hoje um aliado inesperado em certas dimensões da sociedade da informação. Por isso, deverá ser cultivado um sentido das nuances, pelo intelectual face aos jornalista, ou pelo saber face à informação. Se a figura social do intelectual desaparecer, a inteligência poderá sempre subsistir em outras formas. Por exemplo, através de um novo tipo de leitura por parte de um leitor mais activo, que Méchoulan apelida de intelector (intellecteur').

Afinal, se um dito Português defende que um gato tem sete vidas, a quantas mortes e novas vidas consegue o intelectual sobreviver?

\section{Post 7. Media electrónicos e digitais: Reabilitação ou superação do intelectual especialista?}


Quanto à relação entre saber e informação, tem existido, há muito, um mixto de cumplicidade e de tensão ente universitários e jornalistas. Geoffroy de Lagasnerie (2007) reporta que, por um lado, autores como Foucalt, Deleuze e Derrida apoiaram-se em instituições fora da Academia, e nos massmedia impressos em particular, para difundirem as suas ideias contra o academismo universitário. Mas, por outro lado, muitos intelectuais insurgiram-se com as novas condições de circulação do saber, que muitos media subscreviam. Por exemplo, o livro de Bourdieu Sur la Télévision, em 1996, causou uma vivo debate sobre este assunto, ao recusar, para o jornalismo, o direiro de avaliar a produção intelectual. Por outras palavras, defender o pensamento implicaria defender a autonomia universitária. Contudo, uma solução possível seria, para Lagasnerie, apoiando-se em Bourdieu, a aliança entre o pensamento crítico e as palavras 'heréticas'. É quase como se o intelectual ficasse reabilitado por meio de alguma adesão (ou por vezes promiscuidade) aos media.

Uma alternativa a esta reconsversão do intelectual, em termos da sua superação em algo nunca dantes vislumbrado, poderá passarse no ciberespaço e no cibertempo. O debate sobre as actividades intelectuais nos media digitais aponta para direcções diversas, que se torna urgente descodificar. Uma delas é a questão da propriedade intelectual na sociedade da informação (Janssens, 1999). No mundo das TIC, a discussão sobre a propriedade intelectual torna-se ainda mais premente, devido à facilidade de cópia dos conteúdos. Nesta perspectiva, pareceria que a ausência de propriedade em relação ao código de escrita dos softwares, como sucede na proposta do software open source, seria a solução ideal. Contudo, mesmo neste contexto, ocorre ainda perguntar qual a articulação possível e desejável entre a propriedade intelectual e o open source. Mais concretamente: quando começa o trabalho de um participante nesse 
código comum e quando termina ou se sustém? E como guardar um segredo comercial nestas condições? Estas são algumas das interrogações avançadas porV. Lindberg num livro recente (2008).

Outra dúvida, ainda mais problemática e inexplorada, incide na natureza do intelectual na idade da Web 2.0. Neste contexto digital recente, a referida proliferação das figuras sociais da intelectualidade surge contemporaneamente a uma mudança no sentido da relação entre o intelectual, o cidadão comum e o conhecimento não-especialista. Como mencionámos atrás, a partir do acesso expedito de um telemóvel aos instrumentos 'sociais' da Web 2.0 (por exemplo, a escrita e a leitura de lugares da Internet como os blogues, serviços RSS, etc.), qualquer cidadão se pode converter, embora parcialmente, num 'cidadão jornalista'. Esta prática teve origem, em grande parte, na prática das 'reportagens comuns', ou seja as descrições e narrações operadas por cidadãos comuns desde o ataque à estação central de combóios Atocha em Madrid em 2004, muitas vezes em direto e antes dos próprios jornalistas profissionais (Andrade, 2008).

Desenvolvamos estas considerações no quadro dos seus efeitos sociais globais. Uma primeira consequência da proliferação recente de tais práticas, em termos de planetarização das redes de informação, é a chamada sociedade do jornalismo. Trata-se possivelmente de um paradigma social e comunicativo inédito, na medida em que, ao usar boas práticas de cidadania participativa através da internet móvel e do social bookmarking, produz uma espécie de 'cidadãos jornalistas' (Idem, Ibidem).

Uma segunda consequência das considerações anteriores é a seguinte: em termos da reflexão sobre os media, entre outras classificações dos programas de pesquisa dos Communication Studies, já não faz muito sentido utilizar, por ex., a divisão tripartida entre: comunicação interpessoal em co-presença; mass media clássicos; 
e media digitais. Hoje, os espaços sociais de mediação, e os media digitais em especial, apresentam-se essencialmente enquanto media híbridos. Por exemplo, a co-presença virtual, herdeira problemática da co-presença física, constitui um traço central da experiência no ciberespaço, como nos chats, no Skype ou noutras comunicações síncronas. No plano da reflexão sobre esta realidade social globalizada, as próprias taxonomias, classificações e conceptualizações científicas forjadas no dealbar da modernidade, transmutam-se hoje em 'folksnomias', isto é, organizações conceptuais dos conteúdos informativos, em grande parte produzidas pelo utilizador comum, por exemplo através do social bookmarking em sitios fundadores como o site Del-Icio-Us.

\section{Post 8: a emergência da Web 3.0 e o novo knowledge turn}

Uma tal sociedade da investigação e a hibridação dos media conduz-nos diretamente à emergência inexorável da Web 3.0 ou rede social-semântica. Por forma a entender esta nova conjuntura social, consideremos o seguinte: o utilizador ordinário dos wikis e de outros instrumentos da Web 3.0 (como o site Freebase) encontra e constrói, no próprio momento de visita àqueles sítios da Internet, novas configurações do saber, distintas das organizações de significado mais frequentemente usadas hoje em dia na Web 2.0, que não raras vezes se reduzem a descrições (por ex. a informação sobre os espaços sociais, como os lugares visitados em férias) e as narrações (informação acerca dos tempos sociais: eventos excecionais, etc.).

Assim sendo, para muitos utilizadores da Web Social/Web 2.0, seja no Facebook, no Twitter ou no Instagram, de alguma forma a rede funciona enquanto 'social' meramente em sentido restrito. Por seu lado, a Web Social-Semântica/Web 2.0 (mais frequente e 
profundamente do que sucede na Web 2.0), serve-se de classificações, explicações e interpretações, entre outras configurações do saber mais exigentes. Ou seja, a rede social- semântica tem tendência a desvelar-se mais socialmente crítica do que a Web 2.0, adquirindo, por esta via e algo curiosamente, um sentido mais socializador, na medida em que, para além da informação, permite a partilha mais profunda de um conhecimento critico. Assim sendo, uma tal conjuntura do início do terceiro milénio sugere um knowledge turn de natureza não apenas social, mas simultaneamente social e semântica, que encerra consequências ainda imprevisíveis.

Dito de outro modo, para além do novo papel do 'cidadão jornalista', emerge hoje um novo tipo de ator social, o 'cidadão investigador' (Andrade, 2007). A figura do 'cientista comum' (lay scientist) já tinha sido, em parte, preconizada por Albert Schutz, quando este sociólogo falava dos 'conceitos comuns'. De um modo mais abrangente, neste caso ou ainda na atuação de outros membros da intelligentsia interventora no espaço publico digital, deparamo-nos hoje com a figura inédita do intelectual comum (lay intellectual), um agente social não especialista do conhecimento, mas experiente na panóplia dos novos saberes descentralizados.

Um estudo mais recente sobre reportagens comuns opera a tradução das fontes de informação destas reportagens em conhecimento e conceitos comuns, situando-se, deste modo, no seio do paradigma do knowledge turn social e semântico. Trata-se de um livro que analisa as lutas políticas no Portugal atual em plena crise económica, social e cultural, em especial a resistência e crítica contra a austeritocracia que subjaz à política Europeia defensora da austeridade. Num primeiro momento, o fenómeno das lutas sociais nomeadas 'marés' foram reportados e auto-analisados por cidadãos comuns que nelas participaram, através de 3 modos de comunicação: a comunicação em co-presença (murais, graffiti, manifestações); a 
comunicação nos mass media 'clássicos' (jornais, televisão); a comunicação digital (redes sociais digitais). Uma segunda análise de tais confrontos foi efetuada por um sociólogo (Andrade, 2015), por meio de um livro experimental, nomeado Sociological Comics. Trata-se de uma ‘banda desenhada sociológica' que considera a manifestação política como um método sociológico, e desenvolve questões e hipóteses baseadas tanto no sentdo social dessas lutas quanto nos seus significados semânticos mais profundos. Assim sendo, o livro assume-se como uma obra da era da sociedade da investigação e da Web 3.0, onde a pesquisa é levada a cabo tanto por especialistas como um cientista social, quanto pelos cidadãos comuns.

Neste contexto emergente, e em particular, a estruturação das ideias e dos conceitos utiliza instrumentos do pensamento para além das dicotomias, taxonomias e hierarquias, que constituem algumas das estruturas hegemónicas da reflexão racionalista moderna, herdeira directa da lógica formal de Aristóteles ou de Descartes. Por exemplo, no seio da conjuntura intelectual recente, as chamadas 'transcotomias' constituem configurações concetuais do pensamento que têm operado uma articulação de diversificados modos ou tipos de lógicas, podendo investir simultaneamente, para além das lógicas formais e dialéticas, nas lógicas booleanas, nas lógicas fuzzy da Inteligência Artificial, etc. Repare-se nas seguintes formas de transcotomias possíveis, entre outras (Andrade, 2008):

(a) as pluricotomias sociais: trata-se de estruturas sócioconceptuais que utilizam não só 2 pólos conceptuais opostos, como as dicotomias, mas 3 ou mais. A tríade, definida por Georg Simmel, ou seja, o grupo social subjacente à família triangular moderna, é um exemplo disso mesmo. Mas existem outras tricotomias no ciberespaço e no cibertempo actuais. No plano das práticas, o software social esbate a oposição dicotómica, antes muito manifesta, entre o produtor e o utilizador de conteúdos, 
no seio das redes de informação (Web 2.0) e das redes de conhecimento (Web 3.0). Por seu lado, no plano do discurso, os sites da Web 2.0 usam tags (i.e., palavras-chave definidas pelo utilizador comum), que não são necessariamente opostos entre si. No caso da Web 3.0, estas palavras-chave de senso comum encontram-se organizados em redes sócio-conceptuais mediadoras, que manifestam relações hierárquicas, sinonímicas, associativas, ou outras.

(b) as hibricotomias sociais: são configurações sócio-conceptuais que misturam duas ou mais formas da natureza, como o animado e o inanimado. Na Web 2.0, estas maneiras de agir, de pensar e de imaginar revelam-se muito nítidas em mundos virtuais como o Second Life. Aí, o corpo real, físico, não se entende nem funciona sem o seu avatar, ou agente social virtual em rede, ambos edificando uma personalidade híbrida do utilizador da Web 2.0. Com efeito, qualquer um de nós pode ter não só um duplo, um sósia, ou um alter-ego, mas vários, o que permite actuar e pensar o mundo para além do reducionismo dicotómico. Afinal, neste contexto de 3-D colaborativo, já não se sabe quem é o sujeito de quê, nem o que é o objecto de quem. Nas redes sociaissemânticas, estas ações e ideias híbridas desenvolvem-se de maneiras inesperadas.

Assim sendo, e em suma, a cena da comunicação e a natureza do intelectual transformam-se profundamente com o advento dos paradigmas de comunicação difundidos pela Web 2.0, e ainda mais pela Web 3.0 Neste novo ambiente mediático, um dos tipos de intelectual possível é o intelectual comum, que se define como sendo aquele que esbate a diferença entre o amador e o especialista 
da informação, a partir da construção de utensílios ordinários de utilização quotidiana do saber, como as folksonomias nas redes sociais digitais ou as transcotomias nas redes sociais semânticas.

\section{Post 9: a representação do intelectual na Web 3.0: a Wikipedia e o intelectual comum.}

Em seguida, procederemos à apresentação de uma análise do discurso produzido e difundido por um sítio típico da Web 3.0, a Wikipédia. Como se sabe, a Wikipédia, mais do que partilhar informação, comunica conhecimento sobre informação de base. E fá-lo na forma de conceitos que são aí propostos, definidos, desenvolvidos, discutidos e modificados por qualquer utilizador da Internet, seja ele um especialista ou um cidadão comum em geral. Se nos blogues ou nas redes sociais digitais da Web 2.0 a informação é móvel e rapidamente disseminada, num wiki como a Wikipédia o próprio (e o mesmo) conteúdo da informação torna-se objeto de transformação incessante.

Este estudo sobre a Wikipédia foi realizado no projeto de investigação intitulado Comunicação Pública da Arte, financiado pela Fundação para a Ciência e a Tecnologia, e decorreu desde 2007 a 2011 sob minha coordenação.

No exemplo aqui reportado, analisámos a página desse wiki intitulada 'Intelectual', localizada em http://en.wikipedia.org/ wiki/Intellectual . Uma tal estratégia pode fornecer uma das bases empíricas preliminares possíveis para a compreensão do utilizador da Web 3.0, embora restrito ao caso específico da Wikipedia. Antes de mais, distingamos dois planos principais deste processo.

O $1^{\circ}$ é o nível da comunicação social ou plano implícito do discurso. Situamo-nos aqui num plano macrossocial, que considera as estruturas sociais contextualizadoras do utilizador na sua acção. Usaremos simultaneamente uma análise de conteúdo quantitativa e uma interpretação qualitativa. A estrutura social que 
reteremos consiste, essencialmente, no 'discurso', neste caso aquele que a Wikipédia emite na suas web pages. Esse modo discursivo é interpretado e activado pelo visitante, um pouco à maneira que Anthony Giddens aponta: os agentes sociais desenvolvem o sentido da sua própria acção a partir do mutual knowledge ou conhecimento comum que têm das estruturas sociais. A actividade do utilizador reside, neste caso, na leitura, no comentário, na crítica ou na reescrita da página.

$1^{\text {a }}$ questão: que ideias e conceitos mais frequentes se relacionam com o conceito principal 'Intelectual', título da página da Wikipédia lida e eventualmente comentada pelo visitante? Estas noções expressas na web page irão condicionar, directa ou indirectamente, a leitura e a escrita crítica do infonauta.

$\begin{array}{llll}0148 & \text { intellectual } & 0013 & \text { class } \\ 0027 & \text { public } & 0013 & \text { century } \\ 0025 & \text { language_unit } & 0011 & 2004 \\ 0019 & \text { academic } & 0011 & 2006 \\ 0017 & \text { idea } & 0011 & \text { issue } \\ 0016 & \text { role } & 0011 & \text { ideology } \\ 0016 & \text { scholar } & 0011 & \text { academia } \\ 0015 & \text { life } & 0011 & \text { society } \\ 0015 & \text { university } & 0010 & 1997\end{array}$

Fig.1 Conceitos mais frequentes na página 'Intelectual' da Wikipédia

O termo 'intelectual' (v. Fig 1) distancia-se claramente dos outros, registando 148 menções, o que pode significar duas coisas. De um ponto de vista substantivo ou de conteúdo, o conceito parece ser tão importante na dimensão do discurso quanto a relevância que o intelectual quer conferir a si próprio na vida social, política e cultural. Numa perspectiva formal, tal proliferação sugere que se aplicaram, nesta página, poucos sinónimos do termo, pelo menos na língua inglesa. É o caso de 'scholar' 
(mencionado 16 vezes) que, para além da conotação de 'intelectual', 'erudito', 'sábio', inclui muitas vezes um sentido mais restrito, ou seja, significa o 'intelectual académico', ou mesmo o 'bolseiro' e o 'aluno'.

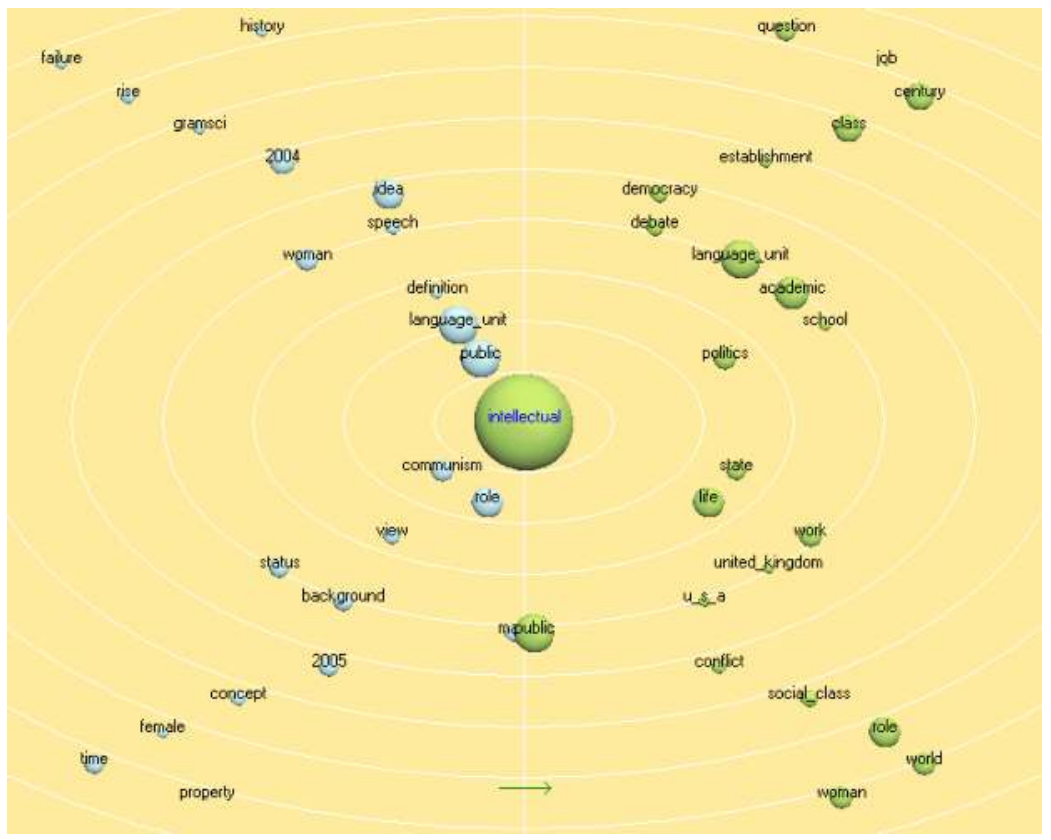

Fig.2 - Campo semântico do conceito 'Intelectual' na Wikipédia

A Fig.2 apresenta as relações conceptuais de uma meneira mais gráfica. $\mathrm{Na}$ imagem, as maiores proximidades espaciais entre as palavras correspondem a mais profundas proximidades de sentido, referidas à totalidade das frases do texto. À esquerda, situam-se os conceitos condicionantes do termo central 'intelectual', e à direita as noções por ele condicionadas. As ideias de 'público', 'comunismo' e 'papel' encontram-se em estreita vizinhança com o intelectual, significando que, de alguma forma, determinam este agente. Tais coincidências também se passam nas obras que comentámos na 
primeira parte deste paper. Para além disso, se olharmos para os conceitos da parte direita da imagem da Fig.1, constataremos que o intelectual influi na 'política' e na 'vida' da 'democracia', através do 'debate' 'público' sobre 'conflitos' e o 'establishment' no 'mundo', etc.

$\mathrm{Na}$ Fig.3, estas relações aparecem expressas em termos mais precisos, a partir do $n^{\circ}$ de menções a esses conceitos, no texto da página em análise.

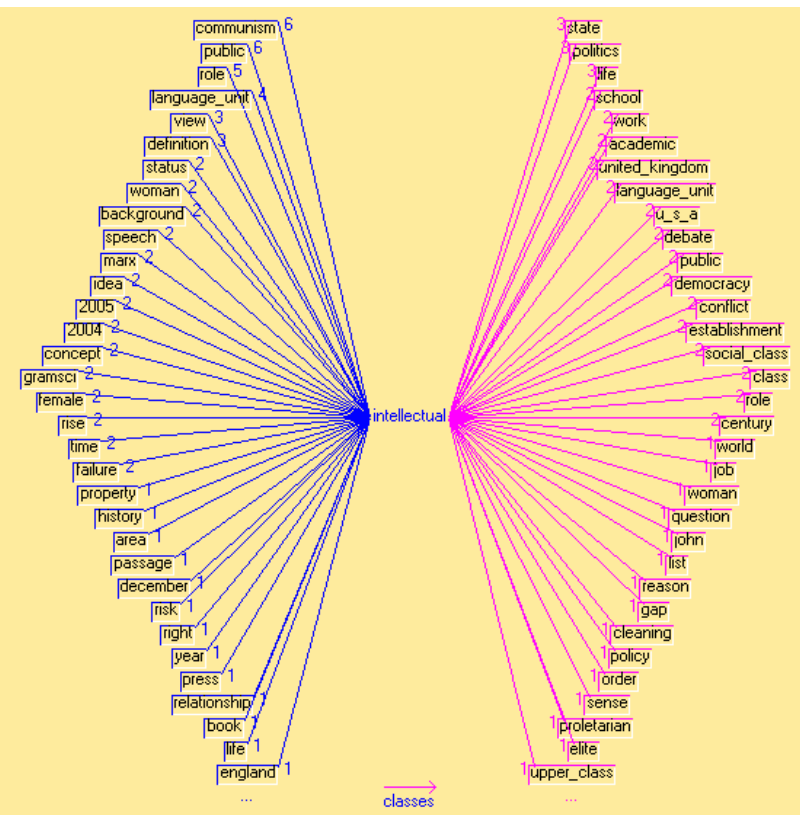

Fig.3 Rede de relações quantitivas do termo 'Intelectual' na Wikipédia

Para além disso, o Thesaurus dos conceitos da web page (Fig.4) organiza os campos semânticos mais notáveis dessa página e da vida social digital dos seus utilizadores, delimitando assim 
um contexto social-semântico característico da Web 3.0. As 'personalidades \& indivíduos' registam uma pontuação elevada (198 menções) bem como a conexão dos intelectuais às questões políticas e sociais (129). Repare-se nos sub-conceitos do campo semântico 'comunicação \& media'. Os modos de comunicação sobressaem, como o debate e a carta, ou a crítica e a discussão, e as referências ao jornalismo também são notórias.

$2^{\mathrm{a}}$ questão: qual o itinerário retórico dos conceitos mais relevantes do texto da página da Wikipédia cujo título é 'Intelectual'? Tal como os conceitos e as suas relações, também as estratégias de persuasão influem nos modos de ler e de rescrever, em linha, o texto das páginas digitais pelo visitante. 


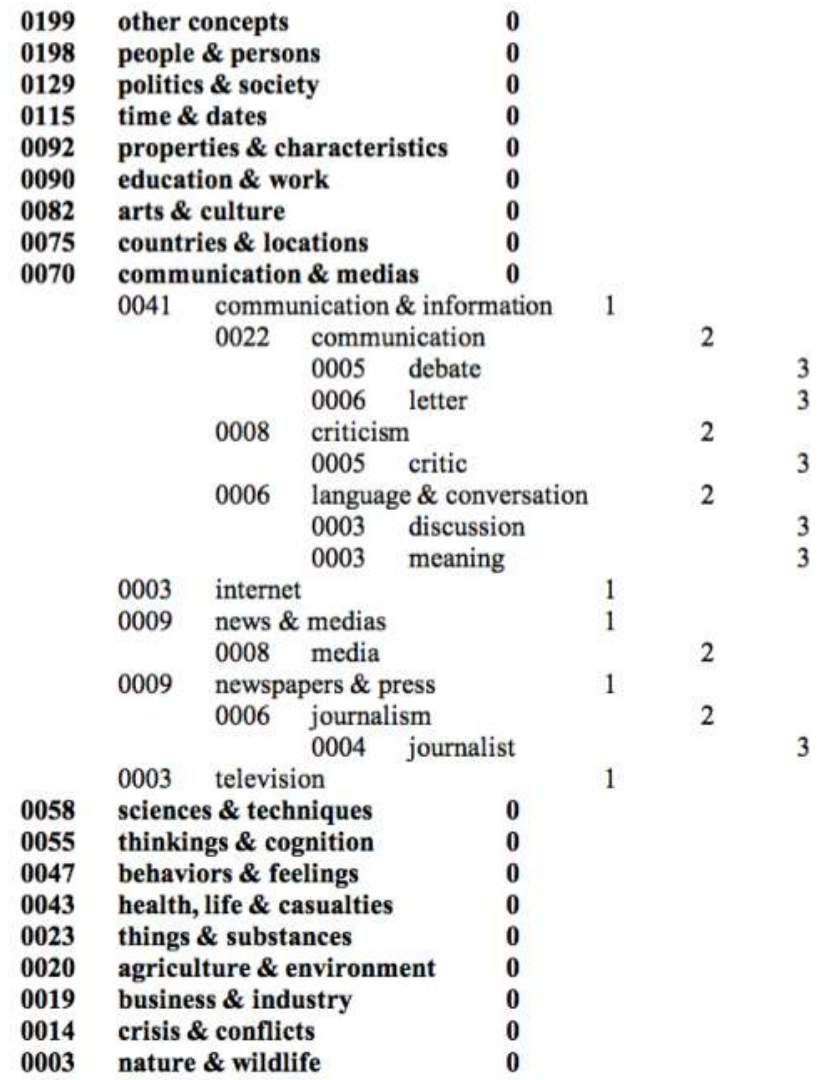

Fig. 4 - Thesaurus dos conceitos da página "Intelectual" da Wikipédia

A Fig. 5 testemunha o percurso argumentativo do conceito central 'intelectual' ao longo da respectiva página. Note-se que existem 3 picos de insistência dessa ideia, no início da página, no meio e no final.

$\mathrm{Na}$ Fig.6, observa-se a progressão dos principais conceitos da página em conjunto. As linhas verticais sinalizam as principais divisões estruturais da web page 'Intelectual'. E a maior ou menor densidade dos termos em certas partes do texto são representados 
pelo maior ou menor comprimento das linhas horizontais. Por exemplo, fala-se muito da relação entre o intelectual, a sociedade e a esfera pública na $4^{a}$ secção definida. A parte seguinte ocupa-se extensivamente da academia ou da ligação da intelligentsia às questões do trabalho, classe social, ideologia e comunismo. As datas na última parte indicam a menção à bibliografia mais importante para a compreensão do tema central da página.

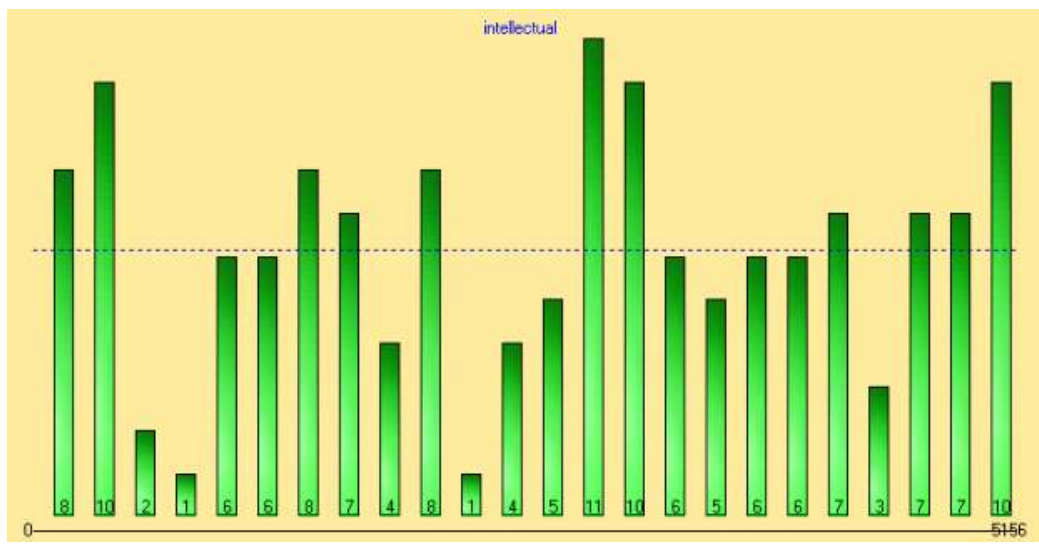

Fig.5 Percurso argumentativo do conceito 'Intelectual' na Wikipédia

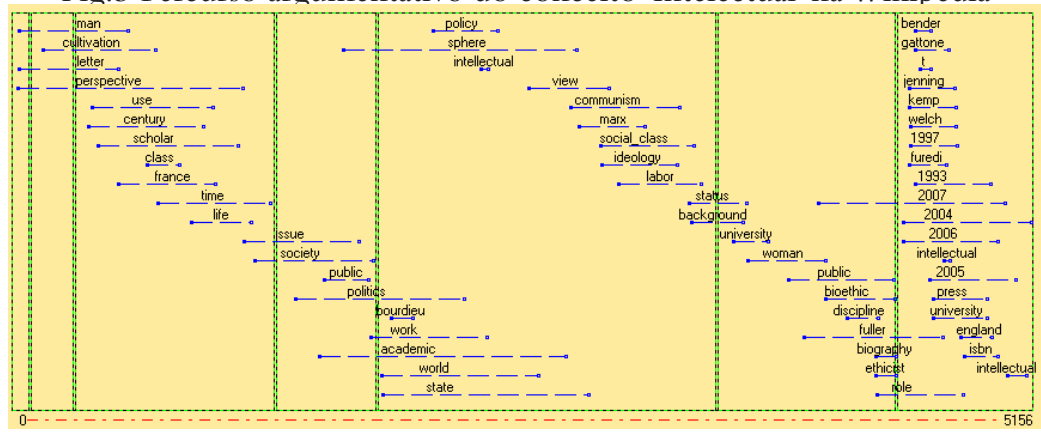

Fig.6 Itinerário retórico dos principais conceitos da página 'Intelectual' da Wikipédia 


\section{O $2^{\circ}$ plano de pesquisa é o nível manifesto ou da comuni-}

cação interactiva. Encontramo-nos aqui num plano microssocial, no qual aplicaremos uma hermenêutica qualitativa ao discurso da web page considerada, a partir de 2 questões fundadoras:

1) Como é que o utilizador da Wikipédia estabelece uma relação interactiva com o conteúdo que é aí exibido?

2) E de que maneira essa articulação transforma a sua actividade numa intervenção de intelectual comum?

Para tentar responder a estas questões, observem-se os comentários, sugestões e modificações que qualquer infonauta pode realizar no próprio conteúdo das páginas da Wikipédia, dentro das regras especificadas para esse efeito para a comunidade virtual. $\mathrm{Na}$ página 'Intellectual', encontram-se 2 comentários: o primeiro critica a falta de referências ou fontes, o segundo sugere uma reformulação do próprio texto (Fig.7).

Role and failures of intellectuals [edit]

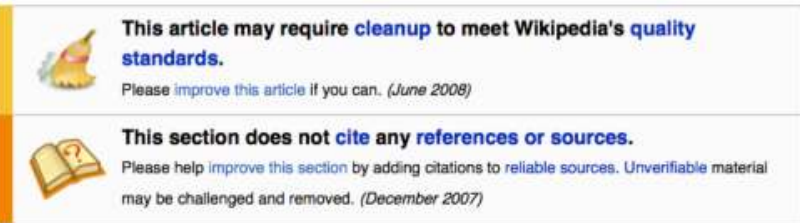

Fig.7 Comentários à página 'Intelectual' da Wikipédia

Assim sendo, eis uma resposta possível à questão 1: o utilizador relaciona-se de forma activa com a informação recebida, ou seja, não somente lê a informação, como também a (re)escreve. A Wikipedia insere-se assim na reading/writing web, ou Web 2.0. São pelo menos três, as consequências de uma tal situação: (a) o utilizador detém alguma autonomia sobre a informação, em termos de 
emissão da sua opinião sobre ela; (b) esta relativa independência da sua voz constitui uma condição necessária, embora não suficiente, para a democratização da Intenet, ainda algo incipiente na primeira idade da rede, anterior à Web 2.0; (c) em terceiro lugar, a escrita opinativa confere-lhe um certo estatuto de autor ou, mais precisamente, de co-autor, embora limitado às condições dessa mesma intervenção que o produtor da página da Wikipédia lhe permite, seja ele um profissional da informação ou não.

A resposta à pergunta 2 pode ser enunciada da seguinte forma: a Wikipédia constitui uma espécie de enciclopédia digital global. Dito de outro modo, os conceitos aí definidos são produzidos e reproduzidos não apenas por especialistas, mas igualmente pelo cidadão comum ou ordinário. E se a conceptualização é uma das actividades mais correntes do intelectual, é legítimo afirmar que os conceitos da Wikipédia são reformulados continuamente pelo intelectual comum em que, por essa via, o infonauta se metamorfoseia.

\section{Post 10. Conclusão: questões e pistas post posts}

As relações entre o intelectual, a Web 2.0 e a Web 3.0, mostram-se ainda problemáticas. A via aberta pelo intelectual comum necessita de ser explorada: (a) tanto pela cooperação mais intensa entre os cidadãos no seio dos instrumentos colaborativos da social web e da social semantic web; (b) quanto através da construção de novas metodologias de reflexão e pesquisa que dissolvam o actual hiato entre o saber especialista e o conhecimento ordinário.

Para um tal debate, lanço em seguida mais 5 pistas de reflexão, na forma de 6 questões para contextualizar as utopias globalizadas no terceiro milénio. Os conceitos convocados por estes dessassossegos e respetivas perguntas encontram-se desenvolvidos em várias obras minhas indicadas na Bibliografia. 
Questão 1: o que é a utopia e o que significa a eventual utopia da utopia

Vamos escolher viver numa utopia negativa (ou-topia ou não-lugar), ou optamos por uma utopia positiva (eutopia ou lugar melhor)? Ou articulamos, dialeticamente, ambos os caminhos?

Questão 2: espaços sociais da vida diária: espaço público/púbico das democracias ou espaço púdico dos fundamentalismos?

$\mathrm{Na}$ dimensão do espaço social do quotidiano, a nossa vida encerra múltiplas vias de vida, decorrentes de tomadas de posição no seio do espaço público e púbico em democracia, ou consequentes de sobreposições e subposições no interior do espaço púdico dos fundamentalismos? Somos solidários e não solitários, ou o inverso?

Questão 3: tempo social do quotidiano: restos, rastos ou rostos?

Neste aspeto, cabe-nos decidir se queremos restos do passado, rostos de cidadãos atuantes, ou rastos que forneçam pistas para um futuro mais inclusivo? Dito de outro modo, almejamos ser conservadores ou conversadores?

Questão 4: esferas sociais de interesses: criação/ invenção/inovação?

As democracias podem revelar-se 'criativas' (segundo o jargão das artes), 'inventoras' (de acordo com o calão da ciência) ou 'inovadoras' (na gíria de economistas e políticos)? Em qual delas nos subscrevemos, 
ou hibridizamos estas 3 vias de vida? Desejamos meros contatos sociais, ou novos contratos sociais?

Questão 5: História e sociologia da globalização: omni-modernidades ou/e pluri-modernidades?

No quadro das recentes deslocalizações da economia mas também das re-localizações das transculturas, seguimos o traço das omni-modernidades ou/e o troço das pluri-modernidades? As omnimodernidades constituem paradigmas de vários modelos mais particulares de sociedade, caraterizados pelo culto da razão, da mesmidade e do global. A modernidade Europeia e Ocidental constitui apenas um modelo particular do paradigma geral 'omnimodernidades'. Por seu turno, as pluri-modernidades definem-se enquanto esquissos de esboços mais específicos do social, circunscritos pelas culturas da sensação, das diferenças e do local. A nomeada pós-modernidade revela-se tão-so um dos caso possíveis das plurimodernidades. (Andrade, De novo, o que vamos seguir, perseguir ou prosseguir?

\section{Questão 6: A HIbridologia nas multiculturas, interculturas ou transculturas?}

Em suma, será que vivemos num mundo onde existem múltiplos encontros mas também encontrões e recontros, por ex. as hibridações ou embates e debates, entre povos, entre espaços e tempos, entre tipos e fluxos de capital, entre políticas (policies e politics), entre interculturas e transculturas? Estas e outras dialéticas e miscenizações podem ser entendidas, de uma feição mais profunda, por uma espécie de Hibridologia? A 
Hibridologia não é uma disciplina (porque não é disciplinar) mas uma figura do saber forjada a partir de outros saberes, principalmente os saberes do Outro. Ou seja, constitui uma reflexão e uma prática sobre o híbrido, essa configuração social, que, na contemporaneidade, mais nos espanta (porque cria novos medos de viver), mas também na medida em que nos espanta (porque cria novos modos de viver)?

\section{Bibliografia}

Andrade, P. (2015). Austerity History Through Sociological Comics. North Charleston: Create Space.

Andrade, P. \& Martins, M. (2015). Cibercultura, Teoria e Métodos na Sociedade da Investigação: Guia Visual-Digital de Boas Práticas para Uso de Bases de Conhecimento Pedagógicas. Braga: Centro de Estudos de Comunicação e Sociedade-CECS.

Andrade, P. (2011a). Sociologia Semântico-Lógica da Web 2.0/3.0 na sociedade da investigação: significados e discursos quotidianos em blogs, wikis, mundos/museus virtuais e redes sociais semântico-lógicas. Lisboa: Edições Caleidoscópio.

Idem (2011b). Novas autorias / leitorias / actorias: escrita comum, literacias híbridas e anti-vigilâncias na Web 2.0. Lisboa: Edições Caleidoscópio.

Idem (2011c). Novela GeoNeológica n 1: um caso de Literatura Transmediática $/ 1^{a}$ Novela da Web 3.0. Lisboa: Edições Caleidoscópio 
Andrade, Pedro (2008). A sociedade da investigação e do jornalismo: boas práticas de cidadania participativa através da internet móvel e do social bookmarking. In "Helena Sousa; Sandra Marinho \& Rui Passos Rocha” (Eds.), Anuário Internacional de Comunicação Lusófona (pp.307-312). Braga: CECS.

Idem, (1997). Navegações no cibertempo: viagens virtuais e virtualidades da ciberviagem. Atalaia, 3,111-124.

Idem, (1996). Sociologia (Interdimensional) da Internet. In Actas do $3^{\circ}$ Congresso Português de Sociologia, 7-9 Fev, Lisboa: APS. [CD-ROM]

Baudrillard, J. (1982). A l'ombre des majorités silencieuses ou la fin du social. Paris: Denoel.

Beau, N. \& Toscer, O. (2006). Une imposture française. Les Arènes.

Bender,T. (1997). Intellect and Public Life. Essays on the Social History of Academic Intellectuals in the United States. The Johns Hopkins Univ. Pr.

Bourdieu, P. (1996). As regras da arte. S.Paulo: Companhia das Letras.

Buxton, D. et al (2006). Les intellectuels de médias en France. L'Harmattan.

Chomsky, N. (1998). Responsabilités des intellectuels. Agone.

Debray, R. (1986), Le pouvoir intellectuel en France. Paris: Gallimard.

Idem (2000). I.F, Suite et fin. Paris: Gallimard. 
Giroux, H. (1988). Teachers as Intellectuals. Toward a Critical Pedagogy of Learning. Bergin \& Garvey.

Jaeglé, C. (2007). L'interview: artistes et intellectuels face aux journalists. Presses Universitaires de France, PUF.

Janssens, T. (1999). Les droit intellectuels dans la société de l'information. Émile Bruylant.

Kouvouama, A. et al (2007). Figures croisées d'intellectuels: trajectoires, modes d'action, productions. Karthala.

Lagasnerie, G. de (2007). L'Empire de l' Université: sur Bourdieu, les intellectuels et le journalism. Ed. Amsterdam.

Leclerc, G.(2003). Sociologie des intellectuels. Presses Universitaires de France . PUF.

Lemieux, E. (2003). Pouvoir intellectual: les Nouveaux Réseaux. Denoel.

Lévy, B.-H. (1988). Eloge des intellectuels. LGF.

Lindberg,V. (2008). Intellectual Property and Open Source. O’Reilly.

Lyotard, J.-F. (1984). Tombeau de l'intellectuel et autres papiers. Galilée.

Méchoulan, E. (2005). Le crépuscule des intellectuels. Nota Bene.

Michael, J. (2000). Anxious Intellects: Academic Professionals, Public Intellectuals, and Enlightenment Values. Duke Univ. Pr. 
Negroni, F. (2006). Le savoir-vivre intellectual. Delga.

Posner, R. (2003). Public Intellectuals: a Study of Decline. Harvard Univ. Pr.

Rambach, A. \& Rambach, M. (2001). Les intellos précaires. Fayard.

Said, E. (1996). Representations of the Intellectual. Vintage.

Sévillia, J. (2004), Le terrorisme intellectual. Libr. Acad. Perrin.

Sokal, A. \& Bricmont, J. (1999). Impostures intellectuelles. LGF.

Spire, A. \& Wolf, J. (1996). Après les grands soirs: Intellectuels et Artistes face au politique. Autrement.

Winock, M. (2006). Le Siècle des intellectuels. Seuil.

Wikipedia, 'Intellectual', http://en.wikipedia.org/wiki/Intellectual, Consultado em 24/11/2008. 